GIRLEY FERREIRA RODRIGUES

ESTUDO DA REDUÇÃO DE PELOTAS DE MINÉRIOS DE FERRO POR HIDROGÊNIO E MISTURA DE HIDROGÊNIO COM MONÓXIDO DE CARBONO 
GIRLEY FERREIRA RODRIGUES

\title{
ESTUDO DA REDUÇÃO DE PELOTAS DE MINÉRIOS DE FERRO POR HIDROGÊNIO E MISTURA DE HIDROGÊNIO COM MONÓXIDO DE CARBONO
}

\author{
Tese apresentada a Escola \\ Politécnica da Universidade de São \\ Paulo como requisito para a \\ obtenção do título de Doutor em \\ Ciências
}

Área de concentração: Engenharia

Metalúrgica e de Materiais

Orientadora: Prof . Associada

Denise Crocce Romano Espinosa

São Paulo 
Este exemplar foi revisado e alterado em relação à versão original, sob responsabilidade única do autor e com a anuência de seu orientador.

São Paulo, 07 de Maio de 2014

Girley Ferreira Rodrigues

Denise Crocce Romano Espinosa

Rodrigues, Girley Ferreira

Estudo da redução de pelotas de minérios de ferro por hidrogênio e mistura de hidrogênio com monóxido de carbono / G.F. Rodrigues. -- São Paulo, 2014. $174 \mathrm{p}$.

Tese (Doutorado) - Escola Politécnica da Universidade de São Paulo. Departamento de Engenharia Metalúrgica e de Materiais.

1. Minérios (Redução) 2. Ferro 3. Hidrogênio I. Universidade de São Paulo. Escola Politécnica. Departamento de Engenharia Metalúrgica e de Materiais II. t. 


\section{Agradecimentos}

Em primeiro lugar agradeço a DEUS pelo dom da vida.

A minha família, familiares e amigos pelo constante apoio e incentivo.

Agradeço a minha orientadora Profạ. Drạ. Denise Crocce Romano Espinosa pela orientação e constante estímulo transmitido durante o trabalho.

Ao $\operatorname{Prof}^{\circ}$. Droํ. Jorge Alberto Soares Tenório pelo estímulo e esforço dispensado a realização dos trabalhos nos laboratórios do LAREX.

Ao Profo Dro $^{\circ}$ Thomaz Augusto Guisard Restivo pelas discussões e ensinamentos sobre cinética química.

Aos colegas e toda a equipe de trabalho do LAREX.

Aos funcionários e técnicos da Escola Politécnica da USP.

A fundação CAPES pela bolsa de estudos 


\section{Resumo}

O problema da emissão de gases de efeito estufa é uma questão que tem ganhado destaque nas recentes convenções internacionais. Adiciona-se a esta questão o fato de o setor siderúrgico ser responsável por parcela significativa nas emissões de gases de efeito estufa. O presente trabalho tem por objetivos estudar processos de redução de minérios de ferro usando hidrogênio e hidrogênio mais monóxido de carbono como redutor para o processo de redução, visando assim à diminuição nas quantidades de $\mathrm{CO}_{2}$ liberadas pelo processo de redução de minérios de ferro. Os minérios foram caracterizados por Microscopia Eletrônica de Varredura, difração de raios-X, quantificação de fases pelo método Rietveld e distribuição granulométrica. Os ensaios de redução foram realizados em balança termogravimétrica e em forno tubular horizontal. A caracterização dos produtos foi realizada usando imagens obtidas por Microscopia Eletrônica de Varredura. Foi constatado que os aumentos da temperatura de redução e do fluxo de gás redutor provocam uma maior degradação física das pelotas. Verificou-se que ocorre a formação de whiskers na superfície externa das pelotas, sendo estes mais freqüentes quando do fluxo combinado de $\mathrm{H}_{2}+\mathrm{CO}$. Verificou-se que as pelotas reduzidas por hidrogênio puro resultaram em maior porosidade tanto no corpo da pelota ou mesmo no interior das partículas. Foi constatado que ocorre a redução homogênea em todas as partículas componentes da pelota. Foi constatado também que o estudo cinético através dos métodos combinados Jump-FSIA é aplicável na redução direta de pelotas de minério de ferro por $\mathrm{H}_{2}$ e $\mathrm{H}_{2}+\mathrm{CO}$. Nas pelotas conformadas a partir de pellet feed com maior área de superfície específica (mais ativas), tanto a cinética quanto a taxa de redução indicaram que a adição de $\mathrm{CO}$ ao gás redutor não influi no processo de redução. A teoria de Sestak-Berggren sugere que o mecanismo controlador na reação global é a difusão podendo estar aliado a outras etapas, compondo um mecanismo misto. 


\begin{abstract}
The problem of the emission of greenhouse gases is an issue that has gained prominence in recent international conventions. Is added to this question the fact that the steel industry is responsible for a significant portion of emissions of greenhouse gases. The present work aims to study ways of reducing iron ore using hydrogen and hydrogen plus carbon monoxide as a reducing agent to the reduction process, thus aiming to decrease the amounts of $\mathrm{CO}_{2}$ released by reduction of iron ores process. The ores were characterized by Scanning Electron Microscopy, X-ray diffraction, phase quantification by Rietveld method and particle size distribution. The reduction assays were performed in thermogravimetric balance and horizontal tubular oven. The characterization of the products was performed using images obtained by scanning electron microscopy. It was found that increases in temperature and reduction in the flow of reducing gas cause greater physical degradation of the pellets. It was found that the formation of whiskers on the outer surface of the pellets occurs most frequently found when combined flow of $\mathrm{H}_{2}+\mathrm{CO}$. It was found that the pellets reduced with pure hydrogen resulted in much higher porosity in the body pellet or even within the particles. It was found that the homogeneous reduction occurs in all components of the particle pellet. It was also found that the kinetic study using the combined methods Jump- FSIA applies in the direct reduction of iron ore pellets by $\mathrm{H}_{2}$ and $\mathrm{H}_{2}+\mathrm{CO}$. In shaped pellets from pellet feed with higher specific surface area (more active), both the kinetics as the rate of reduction indicated that the addition of $\mathrm{CO}$ to the reducing gas has no effect on the reduction process. The Sestak - Berggren theory suggests that the mechanism controlling the overall reaction is diffusion can be combined with other steps, forming a mixed mechanism.
\end{abstract}




\section{Lista de Figuras}

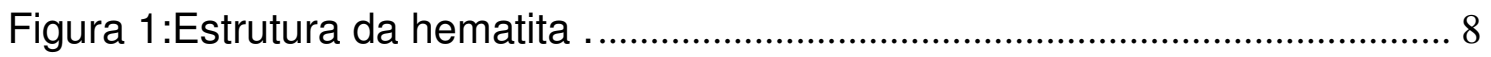

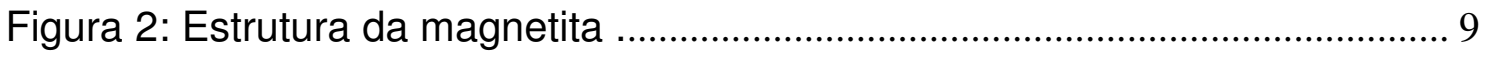

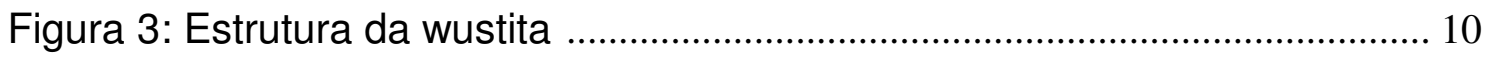

Figura 4: Emissões de $\mathrm{CO}_{2}$ com tecnologias siderúrgicas atuais [].................... 13

Figura 5: Partes do alto forno, movimento da carga e dos gases e exemplos

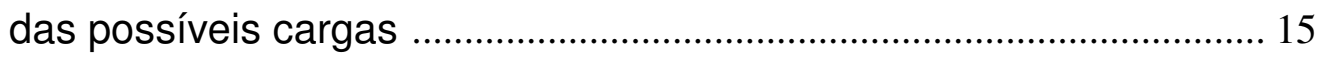

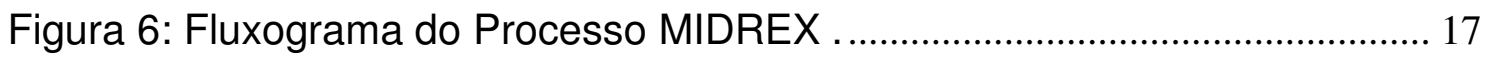

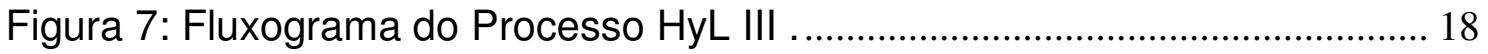

Figura 8: Fluxograma do processo de redução direta em leito fluidizado FIOR

Figura 9: Seção transversal do Forno Tecnored .................................................... 25

Figura 10: Previsão do cenário de produção de aço daqui a 50 anos ............... 26

Figura 11: Parte do diagrama de fases do sistema Fe e O ................................ 28

Figura 12: Diagrama de equilíbrio dos diferentes óxidos de ferro como uma função da composição do gás para Fe-C-O e Fe-H-O em equilíbrio a $1 \mathrm{~atm}$

Figura 13: Representação das etapas de uma reação gás-sólido 30

Figura 14: Micrografias da wustita após a redução de $75 \%$ em hidrogênio seco (à esquerda: $700^{\circ} \mathrm{C}$, direita: $890^{\circ} \mathrm{C}$ )......

Figura 15: Análise das tensões devido as mudanças dimensionais da pelota. a) antes da redução, b) após a redução, c) após a ligação e d) elemento infinitesimal da casca externa

Figura 16: As diferentes fases e a evolução morfológica das partículas durante a redução a $800{ }^{\circ} \mathrm{C}, 10 \% \mathrm{H}_{2}$ em He .

Figura 17: Diagrama do mecanismo de Wagner 42

Figura 18: Seções metalográficas da wustita reduzida a $900{ }^{\circ} \mathrm{C}$. $(A): y=0,1$, $100 \% \mathrm{H}_{2}$, 4min. (B): $\mathrm{y}=0,1,90 \% \mathrm{H}_{2}+10 \% \mathrm{H}_{2} \mathrm{O}, 30 \min .(\mathrm{C}): \mathrm{y}=0,05$, $70 \% \mathrm{H}_{2}+30 \% \mathrm{H}_{2} \mathrm{O}, 420 \min$

Figura 20: Fotografias de whiskers na superfície da camada de ferro 44

Figura 21: Representação esquemática de um crescimento de poros em um defeito de superfície 
Figura 22: Representação esquemática da nucleação de ferro e etapa de crescimento.

Figura 23: Fotomicrografias de MEV da superfície da camada de ferro depois da decomposição 48

Figura 24: Fluxograma das atividades desenvolvidas. 50

Figura 25: Homogeneização e quarteamento dos pellets feed..... 54

Figura 26: Disco pelotizador usado para aglomerar os minérios. 61

Figura 27: Equipamentos utilizados na aglomeração dos minérios e na classificação das pelotas.

Figura 28: Pelotas dispostas em bandejas de aço, prontas para serem secadas.

Figura 29: Navícula com pelotas dentro do forno para realizar a queima das pelotas (sinterização).

Figura 30: Imagens do aparato experimental utilizado para os ensaios no forno tubular.

Figura 31: Detalhe do suporte com as pelotas dos pellets feed e suporte com as amostras dentro do forno.

Figura 32: Aparato utilizado para estudo da redução das pelotas de minério de ferro.

Figura 33: Morfologia das pelotas reduzidas em diferentes temperaturas e diferentes fluxos de gás redutor.

Figura 34: Massa versus tempo para pelota de redução direta ensaiada com fluxo de gás redutor (10\% de hidrogênio + 90\% de argônio) de $50 \mathrm{~mL} / \mathrm{min}$ a diferentes temperaturas $\left(700,800,900,1000\right.$ e $\left.1100{ }^{\circ} \mathrm{C}\right)$ com 1 hora de duração em cada isoterma.

Figura 35: Massa versus tempo para pelota de redução direta ensaiada com fluxo de gás redutor (10\% de hidrogênio + 90\% de argônio) de $100 \mathrm{~mL} / \mathrm{min}$ a diferentes temperaturas $\left(700,800,900,1000\right.$ e $\left.1100{ }^{\circ} \mathrm{C}\right)$ com 1 hora de duração em cada isoterma. 76

Figura 36: Massa versus tempo para pelota de redução direta ensaiada com fluxo de gás redutor (10\% de hidrogênio + 90\% de argônio) de $150 \mathrm{~mL} / \mathrm{min}$ a diferentes temperaturas (700, 800, 900, 1000 e $1100{ }^{\circ} \mathrm{C}$ ) com 1 hora de duração em cada isoterma. 
Figura 37: Massa versus tempo para pelota de redução direta ensaiada com fluxo de gás redutor (10\% de hidrogênio $+90 \%$ de argônio) de $200 \mathrm{~mL} / \mathrm{min}$ a diferentes temperaturas $\left(700,800,900,1000\right.$ e $\left.1100{ }^{\circ} \mathrm{C}\right)$ com 1 hora de duração em cada isoterma. 78

Figura 38: Difratograma do pellet feed $\mathrm{A}$ 80

Figura 39: Difratograma do pellet feed $\mathrm{B}$. 80

Figura 40: Difratograma do pellet feed $\mathrm{C}$. 81

Figura 41: Difratograma da pelota para redução direta. 81

Figura 42: Distribuição granulométrica dos minérios $A, B$ e $C$ realizada por difração a laser.

Figura 43: Imagens de elétrons retroespalhados do Pellet feed A. (A) pellet feed, (B) fração retida na peneira com abertura de 0,149 mm, (C) passante pela peneira com abertura de $0,149 \mathrm{~mm}$ e retida na peneira abertura de $0,088 \mathrm{~mm}$, (D) passante pela peneira com abertura de $0,088 \mathrm{~mm}$ e retida na peneira com abertura de 0,074 mm, $(E)$ passante pela peneira com abertura de $0,074 \mathrm{~mm}$ e retida na peneira com abertura de $0,053 \mathrm{~mm},(\mathrm{~F})$ passante pela peneira com abertura $0,0523 \mathrm{~mm}$ e retida na peneira com abertura de $0,044 \mathrm{~mm}$ e $(G)$ FUNDO fração que passou pela peneira de $0,044 \mathrm{~mm}$.

Figura 44: Imagens de elétrons retroespalhados do Pellet feed B. (A) pellet feed, (B) fração retida na peneira com abertura de $0,149 \mathrm{~mm}$, (C) passante pela peneira com abertura de $0,149 \mathrm{~mm}$ e retida na peneira abertura de $0,088 \mathrm{~mm}$, (D) passante pela peneira com abertura de $0,088 \mathrm{~mm}$ e retida na peneira com abertura de $0,074 \mathrm{~mm}$, (E) passante pela peneira com abertura de $0,074 \mathrm{~mm}$ e retida na peneira com abertura de 0,053 $\mathrm{mm},(\mathrm{F})$ passante pela peneira com abertura $0,0523 \mathrm{~mm}$ e retida na peneira com abertura de $0,044 \mathrm{~mm}$ e $(\mathrm{G})$ FUNDO fração que passou pela peneira de $0,044 \mathrm{~mm}$.

Figura 45: Imagens de elétrons retroespalhados do pellet feed $\mathrm{C}$. (A) pellet feed, (B) fração retida na peneira com abertura de 0,149 mm, (C) passante pela peneira com abertura de $0,149 \mathrm{~mm}$ e retida na peneira abertura de $0,088 \mathrm{~mm}$, (D) passante pela peneira com abertura de $0,088 \mathrm{~mm}$ e retida na peneira com abertura de 0,074 mm, (E) passante pela peneira com abertura de $0,074 \mathrm{~mm}$ e retida na peneira 
com abertura de $0,053 \mathrm{~mm},(\mathrm{~F})$ passante pela peneira com abertura $0,0523 \mathrm{~mm}$ e retida na peneira com abertura de $0,044 \mathrm{~mm}$ e $(\mathrm{G})$ FUNDO fração que passou pela peneira de $0,044 \mathrm{~mm}$.

Figura 46: Massa em função do tempo e temperatura em função do tempo. Pelota do pellet feed A em atmosfera redutora (10\% de hidrogênio + 90\% de argônio).

Figura 47: Fração reagida ( $\alpha$ ) em função do tempo. Pelota do pellet feed $\mathrm{A}$ em atmosfera redutora (10\% de hidrogênio + 90\% de argônio).

Figura 48: Aplicação do método Jump à análise FSIA. Pelota do pellet feed $\mathrm{A}$ em atmosfera redutora (10\% de hidrogênio + $90 \%$ de argônio).

Figura 49: Massa em função do tempo e temperatura em função do tempo. Pelota do pellet feed B em atmosfera redutora (10\% de hidrogênio + 90\% de argônio). 96

Figura 50: Fração reagida $(\alpha)$ em função do tempo. Pelota do pellet feed $B$ em atmosfera redutora (10\% de hidrogênio + 90\% de argônio). 96

Figura 51: Aplicação do método Jump à análise FSIA. Pelota do pellet feed $\mathrm{B}$ em atmosfera redutora de (10\% de hidrogênio + 90\% de argônio) .... 97

Figura 52: Massa em função do tempo e temperatura em função do tempo. Pelota do pellet feed C em atmosfera redutora (10\% de hidrogênio + 90\% de argônio).

Figura 53: Fração reagida ( $\alpha$ ) em função do tempo. Pelota do pellet feed $\mathrm{C}$ em atmosfera redutora (10\% de hidrogênio + 90\% de argônio).

Figura 54: Aplicação do Jump Method à análise FSIA. Pelota do pellet feed C em atmosfera redutora (10\% de hidrogênio + $90 \%$ de argônio). 100

Figura 55: Massa em função do tempo e temperatura em função do tempo. Pelota do pellet feed A em atmosfera redutora $\left.\left(10 \% \mathrm{H}_{2}+90 \% \mathrm{Ar}\right)+\mathrm{CO}\right)$.

Figura 56: Fração reagida ( $\alpha$ ) em função do tempo. Pelota do pellet feed $\mathrm{A}$ em atmosfera redutora $\left.\left(10 \% \mathrm{H}_{2}+90 \% \mathrm{Ar}\right)+\mathrm{CO}\right)$

Figura 57: Aplicação do Jump Method à análise FSIA. Pelota do pellet feed A em atmosfera redutora $\left.\left(10 \% \mathrm{H}_{2}+90 \% \mathrm{Ar}\right)+\mathrm{CO}\right)$.

Figura 58: Massa em função do tempo e temperatura em função do tempo. Pelota do pellet feed B em atmosfera redutora de $\left(10 \% \mathrm{H}_{2}+90 \% \mathrm{Ar}\right)+$ co. 
Figura 59: Fração reagida ( $\alpha$ ) em função do tempo. Pelota do pellet feed $B$ em atmosfera redutora de $\left(10 \% \mathrm{H}_{2}+90 \% \mathrm{Ar}\right)+\mathrm{CO}$

Figura 60: Aplicação do Jump Method à análise FSIA. Pelota do pellet feed B em atmosfera redutora de $\left(10 \% \mathrm{H}_{2}+90 \% \mathrm{Ar}\right)+\mathrm{CO}$. 106

Figura 61: Massa em função do tempo e temperatura em função do tempo. Pelota do pellet feed $\mathrm{C}$ em atmosfera redutora de $\left(10 \% \mathrm{H}_{2}+90 \% \mathrm{Ar}\right)+$ CO. 108

Figura 62: Fração reagida ( $\alpha$ ) em função do tempo. Pelota do pellet feed $\mathrm{C}$ em atmosfera redutora de $\left(10 \% \mathrm{H}_{2}+90 \% \mathrm{Ar}\right)+\mathrm{CO}$ 108

Figura 63: Aplicação do Jump Method à análise FSIA. Pelota do pellet feed $\mathrm{C}$ em atmosfera redutora de $\left(10 \% \mathrm{H}_{2}+90 \% \mathrm{Ar}\right)+\mathrm{CO}$.

Figura 64: Fração reagida em função do tempo da reação de redução em atmosfera de $\mathrm{H}_{2}+\mathrm{Ar}$ e $\mathrm{H}_{2}+\mathrm{AR}+\mathrm{CO}$ para as pelotas dos pellets feed a) A, b) B e c) C.

Figura 65: Fração reagida $x$ tempo para as pelotas dos pellets feed A, B e C reduzidas em atmosferas de $\mathrm{H}_{2}+\mathrm{Ar}$.

Figura 66: Fração reagida $x$ tempo para as pelotas dos pellets feed $A, B$ e C reduzidas em atmosferas de $\mathrm{H}_{2}+\mathrm{Ar}+\mathrm{CO}$.

Figura 67: In (d $\alpha / \mathrm{dt})$ em função de $\ln (\mathrm{f}(\alpha))$ da pelota do pellet feed $\mathrm{B}$ no patamar de $800^{\circ} \mathrm{C}$ para as funções a) $f(\alpha)=\alpha$; b) $f(\alpha)=1-\alpha$ e c) $f(\alpha)=-\ln (1-\alpha) \ldots 117$

Figura 68: Diagrama de Arrhenius da redução utilizando atmosfera de $\mathrm{H}_{2}(10 \%$ de hidrogênio $+90 \%$ de argônio) e $\mathrm{H}_{2}+\mathrm{CO}$ ((10\% de hidrogênio + 90\% de argônio) + monóxido de carbono)) dos pellets feed A, B e C.

Figura 69: Digragrama de Arrhenius genérico para um processo envolvendo difusão

Figura 70: Imagem de MEV no modo elétrons secundários da superfície das pelotas totalmente reduzidas em atmosfera redutora $((10 \%$ de hidrogênio $+90 \%$ de argônio): a) pellet feed $A$, b) pellet feed $B$ e c) pellet feed $\mathrm{C}$.

Figura 71: Imagem de MEV no modo elétrons secundários da superfície das pelotas totalmente reduzidas em atmosfera redutora $((10 \%$ de 
hidrogênio + 90\% de argônio) + (monóxido de carbono): a) pellet feed $\mathrm{A}, \mathrm{b})$ pellet feed $\mathrm{B}$ e c) pellet feed $\mathrm{C}$.

Figura 72: Morfologia da seção das pelotas reduzidas com hidrogênio $\left(\mathrm{H}_{2}\right)$ com aproximadamente 25, 50 e 75\% de redução a) pellet feed A, b) pellet feed $\mathrm{B}$ e c) pellet feed $\mathrm{C}$.

Figura 73: Imagem de MEV no modo elétrons retroespalhados e espectro de EDS da pelota do pellet feed A com aproximadamente $25 \%$ de redução em atmosfera de $\mathrm{H}_{2}+\mathrm{Ar}$ composta por (10\% de hidrogênio + 90\% de argônio). 128

Figura 74: Imagem de MEV no modo elétrons retroespalhados e espectro de EDS da pelota do pellet feed B com aproximadamente $25 \%$ de redução em atmosfera de $\mathrm{H}_{2}+\mathrm{Ar}$ composta por (10\% de hidrogênio + 90\% de argônio).

Figura 75: Imagem de MEV no modo elétrons retroespalhados e espectro EDS da pelota do pellet feed $\mathrm{C}$ com aproximadamente $25 \%$ de redução em atmosfera de $\mathrm{H}_{2}+\mathrm{Ar}$ composta por $(10 \%$ de hidrogênio $+90 \%$ de argônio)..

Figura 76: Morfologia da seção das pelotas reduzidas com (10\% de hidrogênio + argônio) + monóxido de carbono) com aproximadamente 25, 50 e $75 \%$ de redução a) pellet feed $\mathrm{A}$, b) pellet feed $\mathrm{B}$ e c) pellet feed $\mathrm{C} .132$

Figura 77: Imagem de MEV no modo elétrons retroespalhados e espectro de EDS da pelota do pellet feed A com aproximadamente $25 \%$ de redução em atmosfera $\mathrm{H}_{2}+\mathrm{Ar}+\mathrm{CO}$ composta por ((10\% de hidrogênio + 90\% de argônio) + (monóxido de carbono)).

Figura 78: Imagem de MEV no modo elétrons retroespalhados e espectro de EDS da pelota do pellet feed B com aproximadamente $25 \%$ de redução em atmosfera de $\mathrm{H}_{2}+\mathrm{Ar}+\mathrm{CO}$ composta por $((10 \%$ de hidrogênio + 90\% de argônio) + (monóxido de carbono)) . 134

Figura 79: Imagem de MEV no modo elétrons retroespalhados e espectro de EDS da pelota do pellet feed C com aproximadamente $25 \%$ de redução em atmosfera de $\mathrm{H}_{2}+\mathrm{Ar}+\mathrm{CO}$ composta por $((10 \%$ de hidrogênio + 90\% de argônio) + (monóxido de carbono)). 


\section{Lista de Tabelas}

Tabela 1: Propriedades físicas do ferro 5

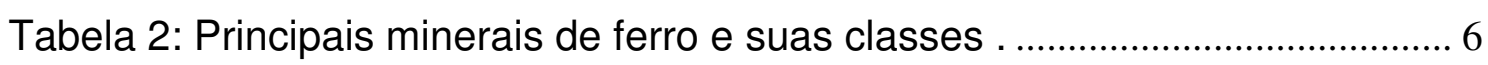

Tabela 3: Reservas mundiais de minério de ferro por país em 2010 . ................ 12

Tabela 5: Composição química dos pellets feed A, B e C e das pelotas para redução direta.

Tabela 6: Ensaios preliminares realizados com pelotas para redução direta. .. 59

Tabela 7: Ensaios de redução em diferentes atmosferas das pelotas dos pellets feed A, B e C.

Tabela 8: Quantificação das fases (\% massa) presentes nas pelotas para redução direta e nos pellets feed $\mathrm{A}, \mathrm{B}$ e $\mathrm{C}$ obtida pelo método de Rietveld. 82

Tabela 9: Resultados dos cálculos estequiométricos calculados a partir da composição química e análise Rietveld.

Tabela 10: Valores da Distribuição do tamanho de partículas dos pellets feed A, B e C obtidos por difração a laser.

Tabela 11: Resultados dos parâmetros avaliados pelo ensaio de adsorção de nitrogênio - método B.E.T. dos pellet feed A, B e C.

Tabela 12: Densidade aparente dos pellets feed A, B e C 86

Tabela 13: Resultados de densidade volumétrica e teórica, e porosidade total para cada um dos tipos de pelotas estudadas, dos pellets feed A, B e C.

Tabela 14: Energias de ativação aparentes calculadas através do método Jump. Pelota do pellet feed A em atmosfera redutora ( $10 \%$ de hidrogênio + 90\% de argônio).

Tabela 15: Energias de ativação calculadas através do método Jump. Minério $B$ em atmosfera redutora (10\% de hidrogênio + 90\% de argônio)........ 98

Tabela 16: Energias de ativação calculadas através do método "jump". Pelota do pellet feed $\mathrm{C}$ em atmosfera redutora ( $10 \%$ de hidrogênio $+90 \%$ de argônio)

Tabela 17: Energias de ativação calculadas através do método Jump. Pelota do pellet feed $\mathrm{A}$ em atmosfera redutora de $\left(10 \% \mathrm{H}_{2}+90 \% \mathrm{Ar}\right)+\mathrm{CO}$...... 104 
Tabela 18: Energias de ativação calculadas através do método Jump. Minério $B$ em atmosfera redutora de $\left(10 \% \mathrm{H}_{2}+90 \% \mathrm{Ar}\right)+\mathrm{CO}$ 107

Tabela 19: Energias de ativação calculadas através do método Jump. Pellet feed $\mathrm{C}$ em atmosfera redutora de $\left(10 \% \mathrm{H}_{2}+90 \% \mathrm{Ar}\right)+\mathrm{CO}$.

Tabela 20: Resumo das energias de ativação aparentes calculadas pelo

Método Jump dos Pellets feed A, B e C utilizando atmosfera de $\mathrm{H}_{2}$ (10\% de hidrogênio + $90 \%$ de argônio) e $\mathrm{H}_{2}+\mathrm{CO}((10 \%$ de hidrogênio + 90\% de argônio) + monóxido de carbono)

Tabela 21: Valores de $E_{a}$ encontrados na literatura. 


\section{Lista de Abreviaturas e Siglas}

COURSE $50-\mathrm{CO}_{2}$ Ultimate Reduction in Steelmaking Process by Innovative Technology for Cool Earth 50 -Redução de $\mathrm{CO}_{2}$ em Processo Siderúrgico pela tecnologia inovadora para resfriamento da terra 50

ULCOS - Ultra-Low Carbon dioxide $\left(\mathrm{CO}_{2}\right)$ Steelmaking - Ultra baixo dioxide de carbono $\left(\mathrm{CO}_{2}\right)$

FSIA - Forced Stepwise Isothermal Analysis - Análise Quase-isotérmica por passos forçada

DRI - Direct Reduction Iron - Ferro reduzido direto

FIOR - Fluid Iron Ore Reduction -Redução de minério de ferro fluído

$\mathrm{HBI} \quad-\quad$ Hot briquetted iron - Ferro briquetado a quente

DRC - Direct Reduction Corporation - Corporação de Redução direta

MEV $\quad$ - Microscopia Eletrônica de Varredura

BET - (Brunauer, Emmett e Teller) método de determinação de superfície específica

ATG - Análise Termogravimétrica

DRX - Difratometria de raios-X 


\title{
Lista de Símbolos
}

\author{
$\mathrm{Fe} \quad-$ Ferro \\ $\mathrm{\alpha}-\mathrm{Fe}_{2} \mathrm{O}_{3} \quad$ - Hematita \\ $\mathrm{Fe}_{3} \mathrm{O}_{4}$ - Magnetita \\ $\mathrm{Fe}_{1-\mathrm{x}} \mathrm{O} \quad-\quad$ Wustita \\ A - Coeficiente pré-exponencial da relação de Ahrrenius (s-1) \\ $\mathrm{E}_{\mathrm{a}} \quad$ - Energia de ativação $(\mathrm{kJ} / \mathrm{mol})$ \\ k $\quad$ - Constante de velocidade $\left(\mathrm{s}^{-1}\right)$ \\ $R \quad$ - Constante dos gases (8,314 J/mol.K) \\ t $\quad-$ Tempo (s) \\ a $\quad$ - Grau de conversão da reação \\ $\Delta \mathrm{G}^{\circ} \mathrm{T} \quad-\quad$ Energia livre padrão na temperatura $\mathrm{T}$ \\ $\Delta \mathrm{m} \quad$ - Variação de massa \\ $\mathrm{X}_{\mathrm{H}} \quad$ - Fração de hematita \\ $\mathrm{X}_{\mathrm{M}} \quad$ - $\quad$ Fração de magnetita \\ $\mathrm{X}_{\mathrm{G}} \quad$ - Fração de goethita \\ $D_{m} \quad-\quad$ A perda de massa teórica máxima até Fe metálico \\ $m_{0} \quad$ - Massa inicial da pelota \\ $\mathrm{m}(\mathrm{t}) \quad$ - $\quad$ Massa da pelota no tempo $\mathrm{t}$ medida na termobalança
}




\section{Sumário}

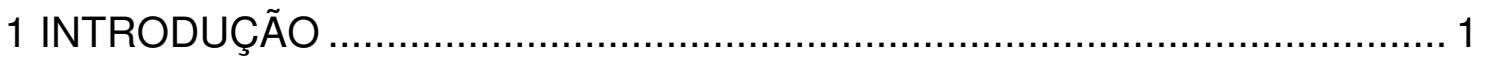

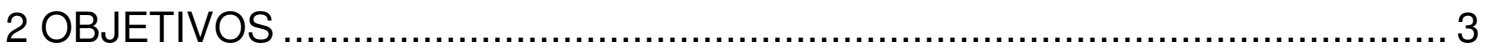

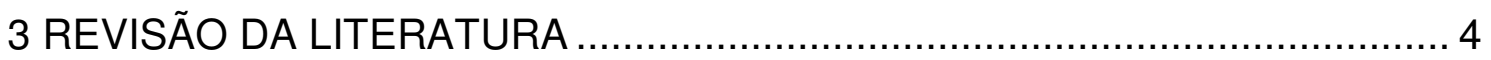

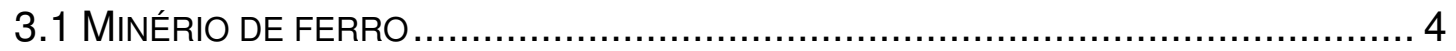

3.1.1 Mineralogia do minério de ferro................................................... 7

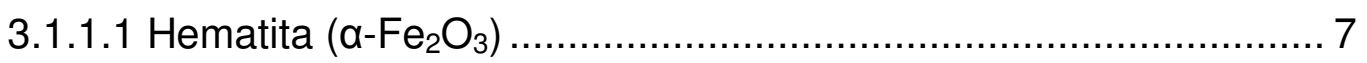

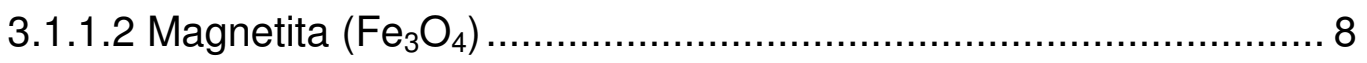

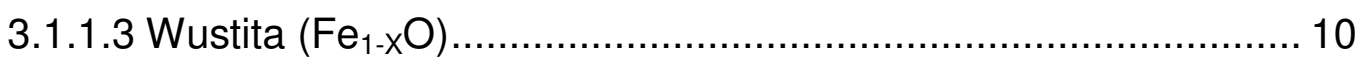

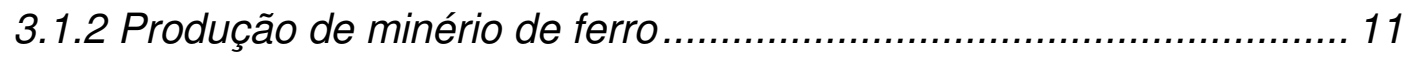

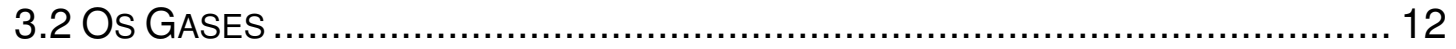

3.3 TÉCNICAS DE REDUÇÃO PARA A OBTENÇÃO DE FERRO METÁLICO …................ 13

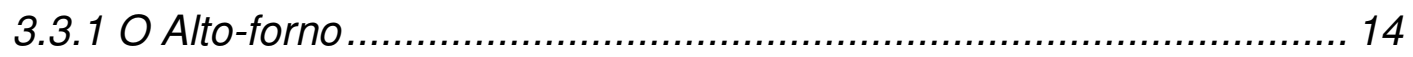

3.3.2 Processos de redução direta....................................................... 15

3.3.2.1 Processos em reator vertical............................................. 17

Processo MIDREX e HyL III .................................................... 17

Processo Purofer ................................................................... 18

3.3.2.2 Processos em leito fluidizado ........................................... 19

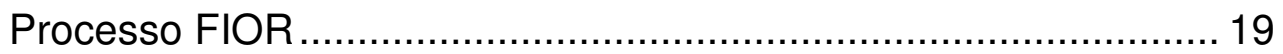

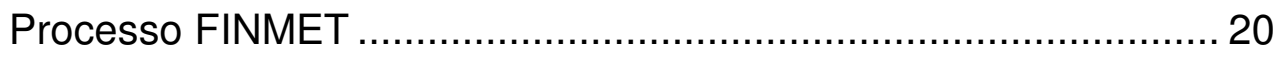

Processo Carboneto de Ferro ......................................................... 20

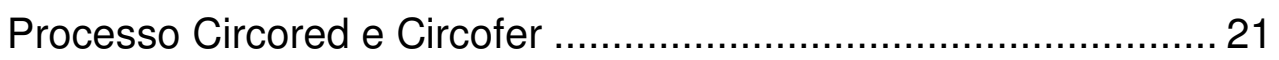

3.3.2.3 Processos em fornos rotativos ............................................... 22

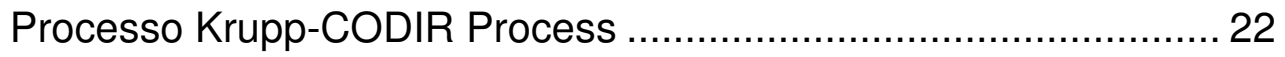

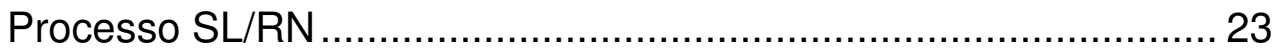

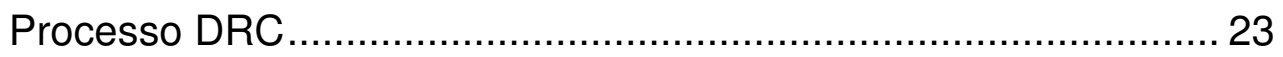

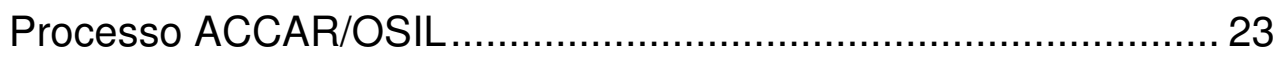

Outros processos com fornos rotativos ……………................... 24

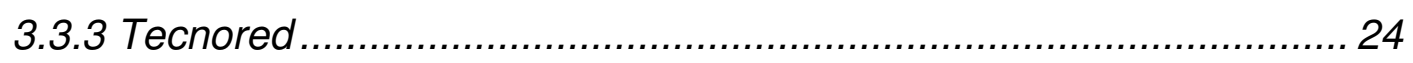

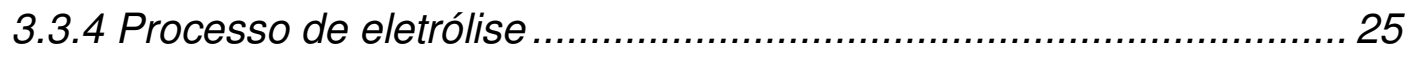

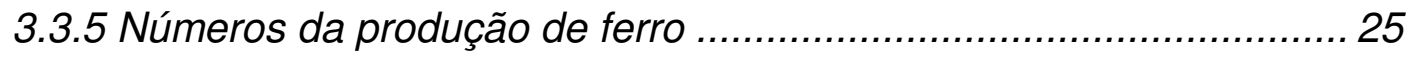

3.4 PROCESSOS DE AGLOMERAÇÃO DE MINÉRIOS DE FERRO ….......................... 26 


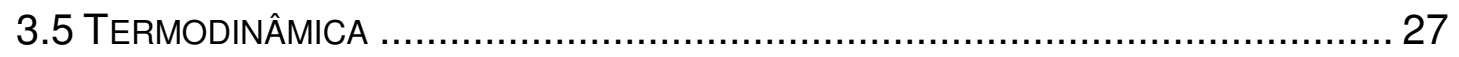

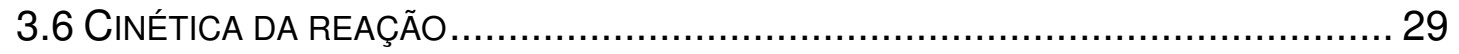

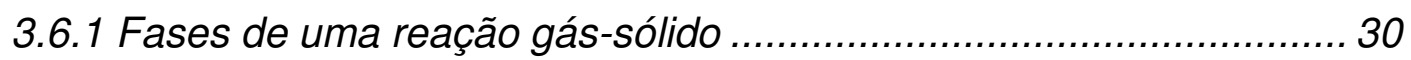

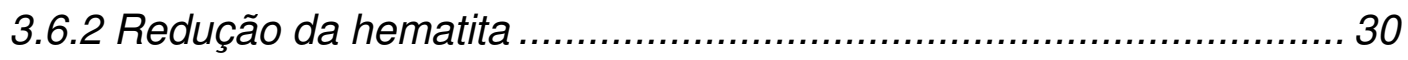

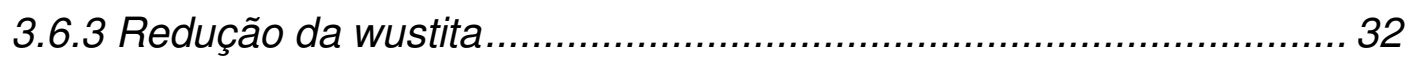

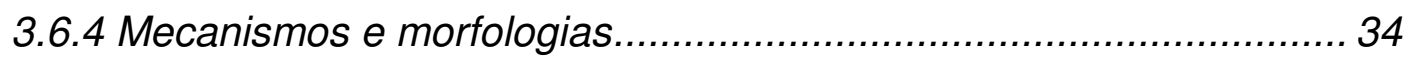

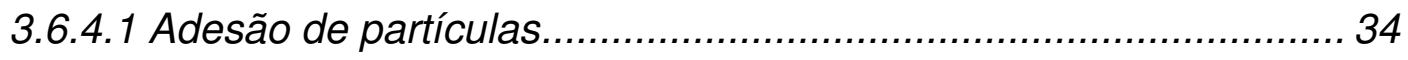

3.6.4.2 Aparecimento de fissuras e trincas em pelotas ........................ 35

3.6.4.3 Estágios na redução da hematita ........................................... 39

3.6.4.3 Mecanismos para a redução da wustita .................................... 41

Mecanismo geral para a redução da wustita.................................... 42

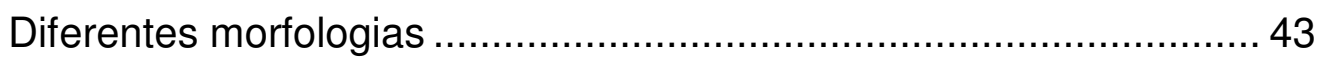

Formação de várias morfologias ................................................... 44

3.7 MÉTODOS DE ESTUDOS DE CINÉTICA POR TERMOGRAVIMETRIA...................... 48

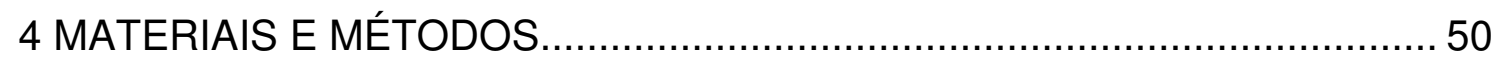

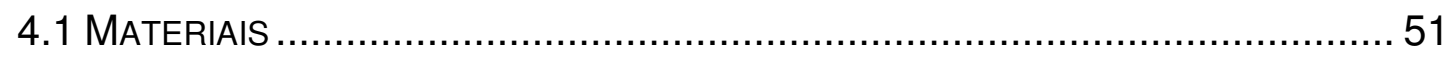

4.1.1 Pellets feed e pelotas para redução direta ................................... 52

4.1.2 Características dos pellets feed e pelotas para redução direta........ 52

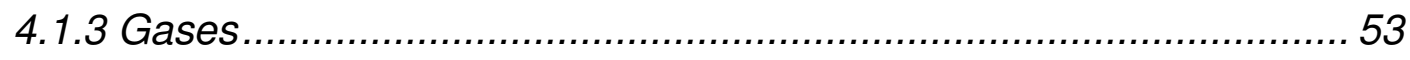

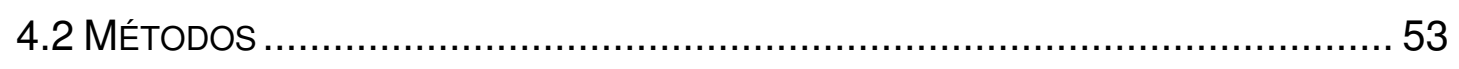

4.2.1 Homogeneização e quarteamento dos Pellets feed ......................... 54

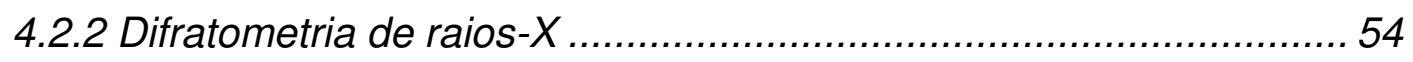

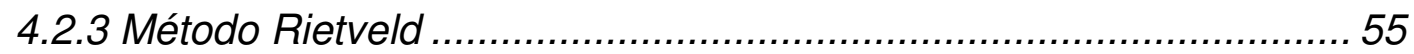

4.2.4 Distribuição de tamanho de partículas ......................................... 55

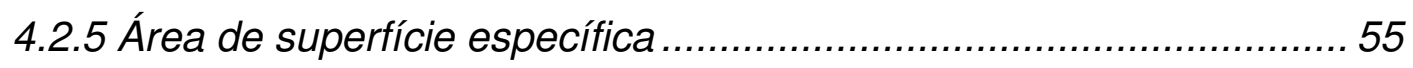

4.2.6 Densidade das partículas dos pellets feed .................................... 56

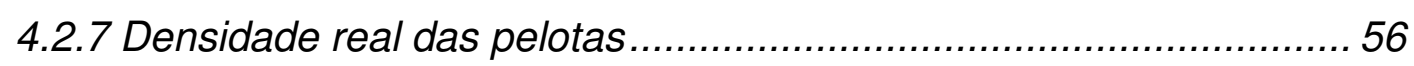

4.2.8 Análises macro e microestrutural ................................................ 57

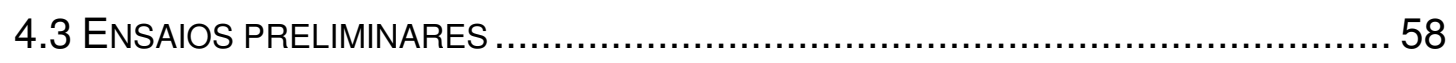

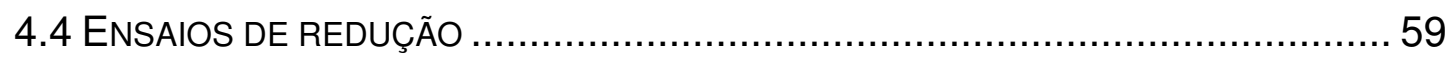

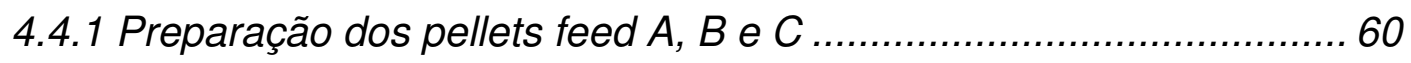

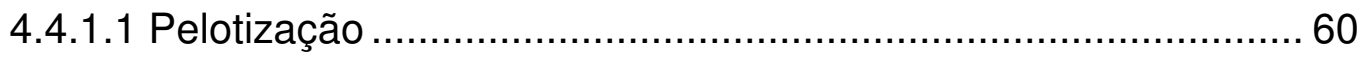

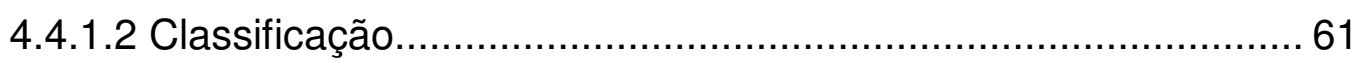




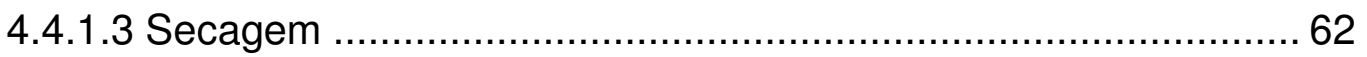

4.4.1.4 Sinterização (queima) das pelotas........................................... 62

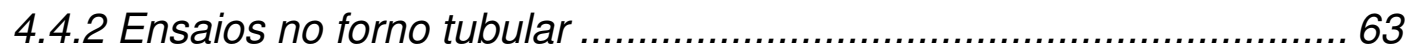

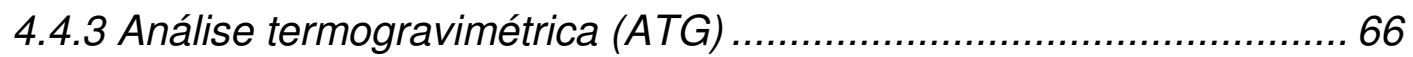

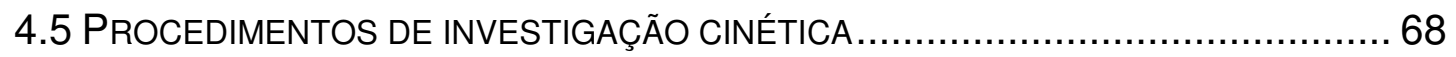

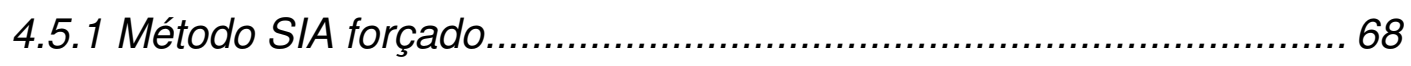

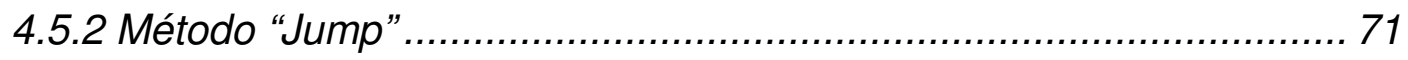

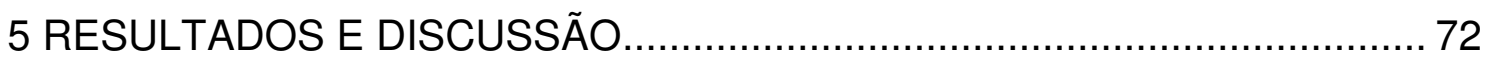

5.1 ENSAIOS DE REDUÇÃO (ENSAIOS PRELIMINARES) …................................. 72

5.1.1 Caracterização macroestrutural .................................................. 72

5.1.2 Ensaios de redução em termobalança (Ensaios preliminares) ........ 75

5.2 CARACTERIZAÇÕES DOS PELLETS FEED A, B E C......................................... 79

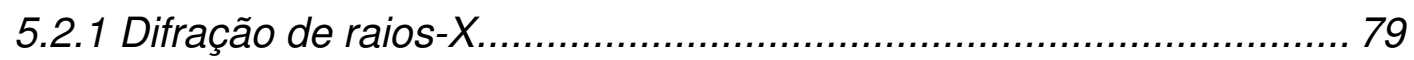

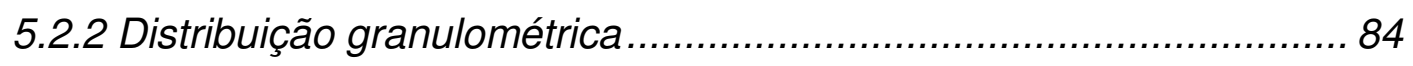

5.2.3 Área de superfície específica ......................................................... 85

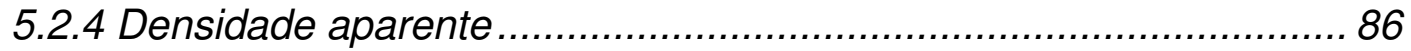

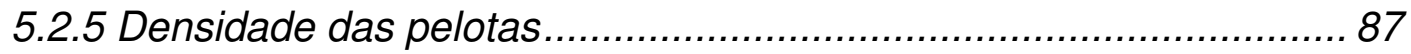

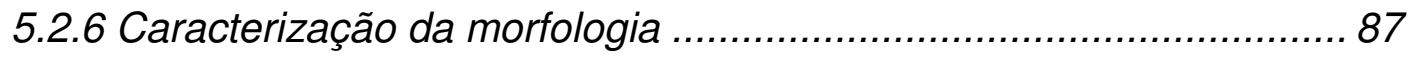

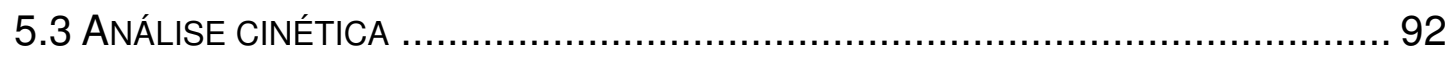

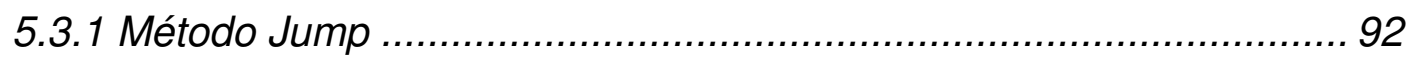

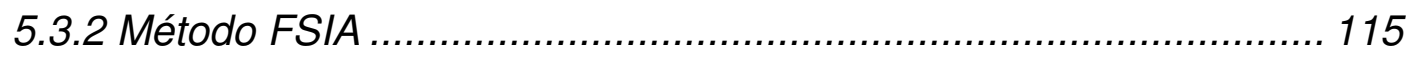

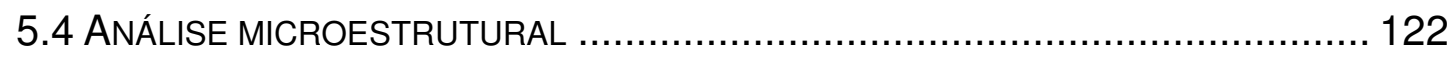

5.4.1 Superfície das pelotas totalmente reduzidas................................ 122

5.4.2 Seções das pelotas com diferentes graus de redução.................... 127

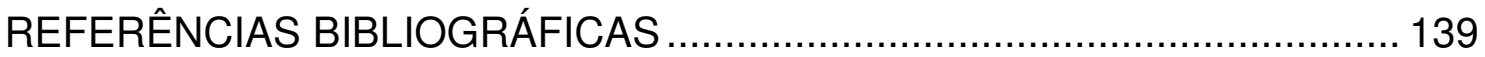




\section{Introdução}

Em 1997, ocorreu a Convenção das Nações Unidas sobre as Alterações Climáticas. Neste encontro foi proposto o Protocolo de Kyoto, que estabelece metas de redução da emissão dos gases que causam o efeito estufa, por parte dos países desenvolvidos, em 5,2\% no período de 2008-2012, com relação aos níveis de 1990. O Protocolo de Kyoto pode ser visto como o primeiro passo de acordos internacionais com o objetivo de estabilizar a concentração na atmosfera dos gases do efeito estufa [1]. Dentre as citações na literatura sobre o efeito estufa devemos citar os estudos publicados por Arrhenius em 1896 [2] que postulou sobre o efeito estufa.

Este tem sido um tema recorrente na literatura [3, 4]. No contexto de desenvolvimento sustentável definido como: "Desenvolvimento que atende às necessidades do presente sem comprometer a capacidade das gerações futuras satisfazerem as suas necessidades", a sustentabilidade tem se tornado uma preocupação global [5]. São citadas metas para que o desenvolvimento sustentável seja alcançado. Especificamente, para a siderurgia sustentável, as metas incluem $[6,7,8]$ :

(1) conservação de recursos, tais como minérios e carvão;

(2) redução da quantidade de $\mathrm{CO}_{2}$ emitida;

(3) reduzir as emissões de outros gases como $\mathrm{SO}_{2}$ e $\mathrm{NO}_{x}$;

(4) reduzir os materiais para aterros; e

(5) reduzir a quantidade de resíduos.

Para aumentar a eficiência energética na produção de ferro primário e aço, e para aplicar as tecnologias convencionais, com o máximo de eficiência, estes temas se tornaram focos de interesse em todo o mundo.

Em condições de concorrência econômica, a introdução, em certos países, de um novo imposto relativo às emissões de $\mathrm{CO}_{2}$ tem-se revelado de importante. Na produção de aço, a maior queda nas emissões de $\mathrm{CO}_{2}$ pode ser atingível por substituição de carbono por hidrogênio como agente redutor [6, 7].

Nesta atual conjuntura, vários países do mundo têm estabelecidos programas para reduzir as emissões dos gases do efeito estufa e diminuir 
energia gasta nos processos de produção de ferro e conseqüentemente do aço. No Japão, existe o programa "COURSE 50" ou " $\mathrm{CO}_{2}$ Ultimate Reduction in Steelmaking Process by Innovative Technology for Cool Earth 50 [9]. Na União Européia, existe o programa ULCOS Ultra-Low Carbon dioxide $\left(\mathrm{CO}_{2}\right)$ Steelmaking [10]. Nos Estados Unidos o American Iron and Steel Institute também cita pesquisas que visam a sustentabilidade nas indústrias de produção de aço [11]. Há também programas em curso na Coréia do Sul e na Austrália [12]. Nestes programas, os temas principais de pesquisa são muito semelhantes. As pesquisas enfocam na redução de minério de ferro por hidrogênio, eletrólise de minério de ferro e no seqüestro e armazenamento de $\mathrm{CO}_{2}$ oriundo dos processos siderúrgicos.

Este trabalho visa estudar a redução de minérios de ferro, utilizando como gás redutor $\mathrm{o}$ hidrogênio e hidrogênio com monóxido de carbono empregando a metodologia de análise cinética combinada Jump-FSIA, e mostrar um possível desenvolvimento tecnológico de redução de minério de ferro por hidrogênio. 


\section{Objetivos}

Os objetivos deste trabalho são:

1. Investigar os fatores (temperatura e fluxo de gás redutor) que interferem na redução direta de pelotas de minério de ferro por hidrogênio.

2. Realizar a caracterização das pelotas obtidas após os ensaios de redução direta utilizando uma mistura de gás redutor contendo argônio e hidrogênio e outra contendo monóxido de carbono e hidrogênio com argônio.

3. Verificar a morfologia das pelotas em diferentes graus de redução.

4. Estudar a cinética de redução de pelotas de três tipos de pellets feed por hidrogênio e de uma mistura de hidrogênio e monóxido de carbono pelo método "Stepwise Isothermal Analysis", "SIA". 


\section{Revisão da literatura}

Será apresentada uma revisão sobre a mineralogia dos minérios de ferro. Números sobre a produção de minérios de ferro. Um enfoque é dado nas fases mineralógicas que podem aparecer durante a redução da fase hematita para a obtenção de ferro metálico. São citados vários processos de produção de ferro primário. Alguns destes são descritos sucintamente. Também são apresentados os aspectos termodinâmicos e cinéticos envolvidos no processo de redução de minérios de ferro.

\subsection{Minério de ferro}

O ferro é um elemento do grupo 8 na tabela periódica, tem número atômico 26 e massa atômica 55,65. É o quarto elemento mais abundante da crosta terrestre, representa em torno de $5 \%$ da massa da crosta terrestre. 0 ponto de fusão é $1535^{\circ} \mathrm{C}$. É uma das principais matérias-primas para a indústria. Uma vez que o ferro e o aço estão presentes em uma variedade de produtos, o consumo de minério de ferro ainda é um dos índices considerados na medida de industrialização de um país [13, 14].

O ferro ocorre como constituinte majoritário ou minoritário em todas as classes minerais. Essa diversidade existe, devido a sua abundância e alta capacidade de oxidar ou reduzir conforme o ambiente. Mais de 400 minerais apresentam $\mathrm{Fe}$ em teores detectáveis, cujas concentrações variam de menos de $1 \%$ a mais de $70 \%$. Apesar da ampla distribuição dos minerais de ferro, apenas poucas classes minerais são consideradas economicamente exploráveis. Isso ocorre pela quantidade de ferro presente nesses minerais ou pela concentração desses minerais nas rochas, que formam os corpos de minérios. Os minérios de ferro considerados economicamente exploráveis são agrupados de acordo com a sua composição química, nas classes: óxidos, carbonatos, sulfetos e silicatos, sendo esta última de menor expressão econômica [13, 18]. A Tabela 1 algumas propriedades físicas do ferro. 
Tabela 1: Propriedades físicas do ferro [13].

\begin{tabular}{l|c}
\hline Densidade a $20^{\circ} \mathrm{C}, \mathrm{g} / \mathrm{cm}^{3}$ & 7,874 \\
\hline $\begin{array}{l}\text { Coeficiente de expansão térmica a } \\
20^{\circ} \mathrm{C}\end{array}$ & $11,7 \times 10^{-6}$ \\
\hline Constante da rede, cm & $2,861 \times 10^{-8}$ \\
\hline Ponto de fusão, ${ }^{\circ} \mathrm{C}$ & 1535 \\
\hline $\begin{array}{l}\text { Temperatura de transformação } \alpha, \mathrm{v} \\
\text { em aquecimento }{ }^{\circ} \mathrm{C}\end{array}$ & 910 \\
\hline $\begin{array}{l}\text { Temperatura de transformação } \mathrm{V}, \delta \\
\text { em resfriamento }{ }^{\circ} \mathrm{C}\end{array}$ \\
\hline
\end{tabular}

Nota-se da Tabela 1 que o ferro apresenta transformações de fases.

Os minerais de ferro considerados economicamente exploráveis pertencem às classes anteriormente citadas, como pode ser visto na Tabela 2. Cada classe de minerais pode ser representada por um ou mais minerais, sendo que destes, apenas os minerais de ferro da classe óxido, são explorados economicamente, nas condições atuais [15]. 
Tabela 2: Principais minerais de ferro e suas classes [15].

\begin{tabular}{|c|c|c|c|c|}
\hline \multirow[b]{2}{*}{ Classe } & \multirow[b]{2}{*}{$\begin{array}{c}\text { Nome } \\
\text { mineralógico }\end{array}$} & \multirow[b]{2}{*}{$\begin{array}{l}\text { Composição química do } \\
\text { metal puro }\end{array}$} & \multicolumn{2}{|l|}{ Teor } \\
\hline & & & $\begin{array}{l}\text { de } \\
\mathrm{Fe} \\
(\%)\end{array}$ & $\begin{array}{l}\text { Designação } \\
\text { comum }\end{array}$ \\
\hline \multirow{4}{*}{ Óxidos } & Magnetita & $\mathrm{Fe}_{3} \mathrm{O}_{4}$ & 72,4 & $\begin{array}{l}\text { Óxido } \\
\text { ferroso- } \\
\text { férrico }\end{array}$ \\
\hline & Hematita & $\mathrm{Fe}_{2} \mathrm{O}_{3}$ & 69,9 & $\begin{array}{l}\text { Óxido } \\
\text { férrico }\end{array}$ \\
\hline & & $\mathrm{HFeO}_{2}$ - Goethita & 62,8 & $\begin{array}{l}\text { Hidróxido } \\
\text { de ferro }\end{array}$ \\
\hline & & $\mathrm{FeO}(\mathrm{OH})$ - Lepidocrocita & 62,85 & \\
\hline Carbonato & Siderita & $\mathrm{FeCO}_{3}$ & 48,2 & $\begin{array}{l}\text { Carbonato } \\
\text { de ferro }\end{array}$ \\
\hline \multirow{2}{*}{ Sulfetos } & Pirita & $\mathrm{FeS}_{2}$ & 46,5 & \\
\hline & Pirrotita & $\mathrm{FeS}$ & 63,6 & \\
\hline \multirow{5}{*}{ Silicatos } & Fayalita & $\mathrm{Fe}^{2+}{ }_{2}\left(\mathrm{SiO}_{4}\right)$ & 54,81 & $\begin{array}{l}\text { Grupo } \\
\text { olivina }\end{array}$ \\
\hline & Laihunite & $\mathrm{Fe}^{2+} \mathrm{Fe}^{3+}{ }_{2}\left(\mathrm{SiO}_{4}\right)_{2}$ & 47,64 & $\begin{array}{l}\text { Grupo } \\
\text { olivina }\end{array}$ \\
\hline & Greenalita & $\mathrm{Fe}^{2+}{ }_{2} .3 \mathrm{Fe}^{3+} 0.5 \mathrm{Si}_{2} \cdot 2 \mathrm{O}_{5}(\mathrm{OH}) 3.3$ & 44,14 & $\begin{array}{c}\text { Grupo } \\
\text { serpentina }\end{array}$ \\
\hline & Grunerita & $\mathrm{Fe}^{2+} 7\left(\mathrm{Si}_{8} \mathrm{O}_{22}\right)(\mathrm{OH})_{2}$ & 39,03 & $\begin{array}{l}\text { Grupo dos } \\
\text { anfibólios }\end{array}$ \\
\hline & Fe-antofilita & $\mathrm{Fe}^{2+} 7\left(\mathrm{Si}_{8} \mathrm{O}_{22}\right)(\mathrm{OH})_{2}$ & 39,03 & $\begin{array}{l}\text { Grupo dos } \\
\text { anfibólios }\end{array}$ \\
\hline
\end{tabular}




\subsubsection{Mineralogia do minério de ferro}

Nesta seção são discutidas as estruturas da hematita, magnetita e wustita. Estas são as possíveis fases durante a redução da hematita.

\subsubsection{Hematita $\left(\alpha-\mathrm{Fe}_{2} \mathrm{O}_{3}\right)$}

A hematita tem a composição química de $\mathrm{Fe}_{2} \mathrm{O}_{3}$, correspondendo a $69,94 \%$ de ferro e 30,06 \% de oxigênio; é de cor cinza azulado a vermelho, brilhante a fosca, podendo ser terrosa, compacta ou cristalina, com massa específica de $5,26 \mathrm{~g} / \mathrm{cm}^{3}[16,17]$. A hematita pode ocorrer em vários tipos de rochas [15]. Ocorre como mineral primário associado a depósitos de veios, rochas ígneas, metamórficas e sedimentares e também como produto de alteração da magnetita [15].

Ela é isoestrutural com o córindo sua célula unitária é hexagonal, com parâmetros $\mathrm{a}=0,5034 \mathrm{~nm}$ e $\mathrm{c}=1,3752 \mathrm{~nm}$, com seis fórmulas mínimas por célula unitária [18].

Estruturalmente, a hematita consiste em planos de átomos de oxigênio em empacotamento denso hexagonal do tipo $A B A B A B$... em seqüência ao longo do eixo cristalográfico $z$ (direção [001]). Íons $\mathrm{Fe}^{3+}$ ocupam 2/3 dos espaços octaédricos, onde cada $\mathrm{Fe}$ é rodeado por seis oxigênios, e cada oxigênio é compartilhado por quatro íons de $\mathrm{Fe}^{3+}$. Esta estrutura tripla $\mathrm{Fe}-\mathrm{O}_{3}-\mathrm{Fe}$ influência nas propriedades magnéticas do óxido [18].

$\mathrm{O}$ arranjo dos cátions produz pares de octaedros de $\mathrm{Fe}(\mathrm{O})_{6}$, cada um compartilhando suas arestas com três octaedros vizinhos no mesmo plano, e uma com um octaedro em um plano adjacente [15]. A Figura 1 mostra a estrutura cristalina da hematita. 
a

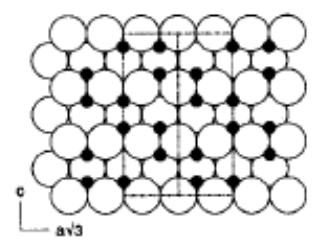

b

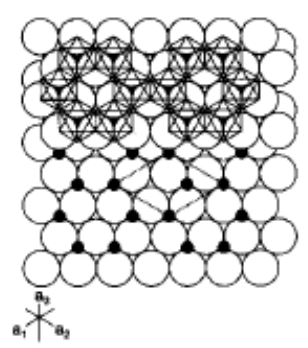

e

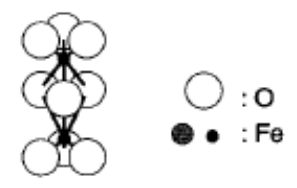

C
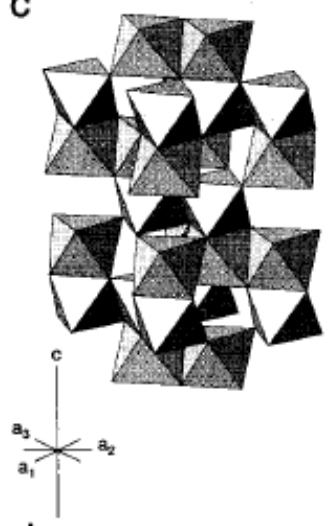

d

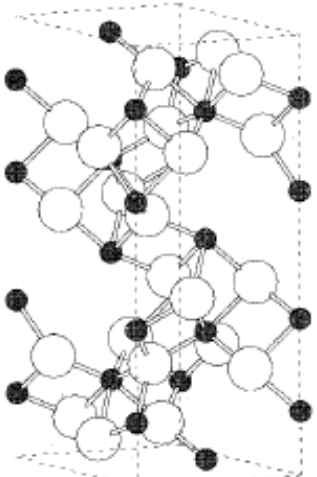

Figura 1:Estrutura da hematita [18].

a) Empacotamento hexagonal de oxigênios com cátions distribuídos nos interstícios octaédricos.

b) Visão abaixo do eixo c que mostra a distribuição de íons Fe sobre uma camada de oxigênio e o arranjo hexagonal de octaedros.

c) Arranjo de octaedros

d) Modelo de bolas e bastões.

e) Arranjos de $\mathrm{O}_{3}-\mathrm{Fe}-\mathrm{O}_{3}-\mathrm{Fe}-\mathrm{O}_{3}$.

\subsubsection{Magnetita $\left(\mathrm{Fe}_{3} \mathrm{O}_{4}\right)$}

A magnetita tem a composição química de $\mathrm{Fe}_{3} \mathrm{O}_{4}$, correspondendo a $72,36 \%$ de ferro e $27,64 \%$ de oxigênio; tem cor cinza a preto e massa específica de 5,16 a $5,18 \mathrm{~g} / \mathrm{cm}^{3}$ [19]. É um mineral fortemente magnético, às vezes, age como magneto natural. A sua propriedade magnética é importante, pois auxilia na exploração por métodos magnéticos, nos quais a magnetita pode ser separada via separação magnética, da ganga produzindo um concentrado de alta qualidade [15, 18]. A Figura 2 mostra a estrutura da magnetita. 

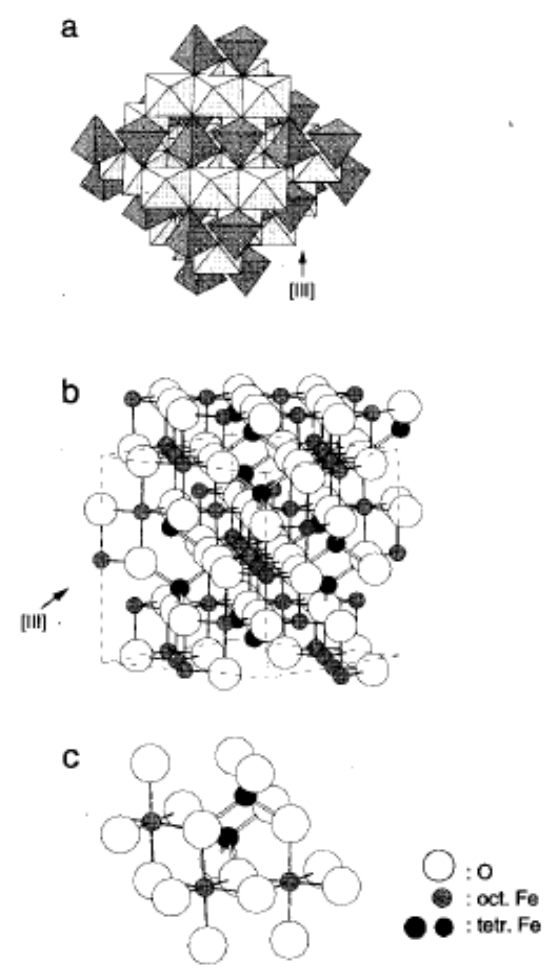

Figura 2: Estrutura da magnetita [18].

a) Modelo poliédrico com a alternância de camadas de octaedros e tetraedrosoctaedros.

b) Modelo de bolas e bastões.

c) Modelo de bolas e bastões do arranjo de octaedros e tetraedros.

A célula unitária da magnetita é cúbica, com parâmetro $a=0,839 \mathrm{~nm}$, tendo oito fórmulas mínimas por célula unitária, e sua estrutura é de espinélio invertido. A magnetita tem a face centrada da célula unitária cúbica alicerçada em 32 íons $\mathrm{O}^{2-}$ regularmente arranjados ao longo da direção [111]. A magnetita difere dos demais óxidos de ferro por conter o ferro bivalente $\left(\mathrm{Fe}^{2+}\right)$ e $\mathrm{O}$ trivalente $\left(\mathrm{Fe}^{3+}\right)$. Sua fórmula é escrita como $\mathrm{Y}[\mathrm{XY}] \mathrm{O}_{4}$ onde $\mathrm{X}=\mathrm{Fe}^{2+}, \mathrm{Y}=\mathrm{Fe}^{3+} \mathrm{e}$ os colchetes denotam os sítios octaédricos (sítios $\mathrm{B}$ ). Os sítios tetraédricos (sítios $\mathrm{A}$ ) são ocupados por íons $\mathrm{Fe}^{3+}$, enquanto que os sítios octaédricos são ocupados pelos íons $\mathrm{Fe}^{2+}$ e $\mathrm{Fe}^{3+}$. A estrutura consiste em camadas octaédricas e tetraédrica/octaédrica empacotadas ao longo da direção [111] [18].

Uma célula unitária da magnetita contém dezesseis íons $\mathrm{Fe}^{3+}$, oito $\mathrm{Fe}^{2+} \mathrm{e}$ oito íons $\mathrm{Fe}^{3+}$ nos sítios tetraédricos, enquanto que oito $\mathrm{Fe}^{3+}$ e oito $\mathrm{Fe}^{2+}$ são distribuídos nos sítios octaédricos [18]. 


\subsubsection{Wustita $\left(\mathrm{Fe}_{1-\mathrm{x}} \mathrm{O}\right)$}

A wustita é um óxido de ferro antiferromagnético negro que possui apenas $\mathrm{Fe}(\mathrm{II})$ em sua estrutura, mas geralmente ela não é estequiométrica, por isso é frequentemente representada como $\mathrm{Fe}_{1_{1} \mathrm{XO}} \mathrm{O}$, embora sua fórmula seja representada como $\mathrm{FeO}$. A ausência da estequiometria deve-se à oxidação de parte dos íons de ferro e da criação de lacunas catiônicas [20].

A wustita é um intermediário no processo de redução dos minérios de ferro. Sua forma mais estável, deficiente em cátions, existe em pressões da ordem de $0,1 \mathrm{MPa}$ e temperaturas superiores a $567{ }^{\circ} \mathrm{C}$. Quando resfriada lentamente para temperaturas menores que $567^{\circ} \mathrm{C}$, esta fase se decompõe em $\mathrm{Fe}^{0}$ e $\mathrm{Fe}_{3} \mathrm{O}_{4}$. No entanto, se $\mathrm{Fe}_{1-\mathrm{X}} \mathrm{O}$ for esfriado muito rapidamente, a forma não estequiométrica pode ser obtida como uma fase metaestável a temperatura ambiente [18].

Sua estrutura é baseada no empacotamento cúbico dos ânions. A Figura 3 mostra a estrutura da wustita.

a

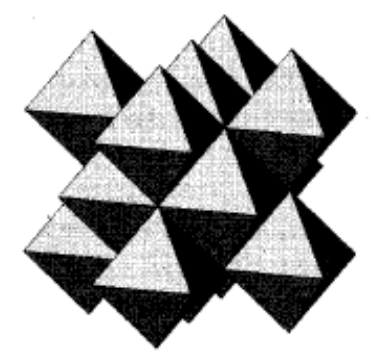

b

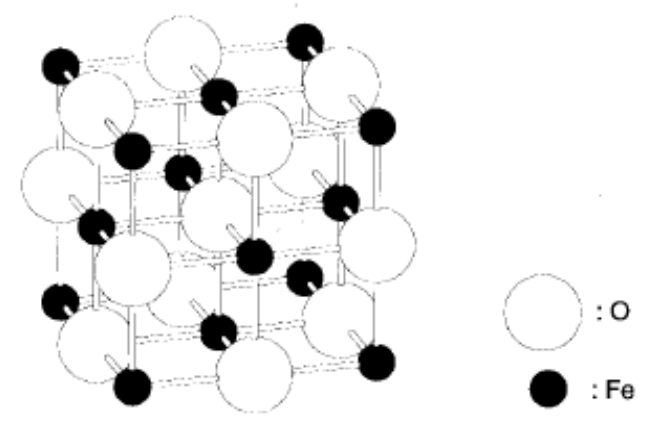

Figura 3: Estrutura da wustita [18].

a) Arranjo de octaedros.

b) Modelo de bolas e bastões. 


\subsubsection{Produção de minério de ferro}

O elemento Fe por ser abundante na crosta terrestre pode ocorrer a acumulação de minérios em diversos ambientes geológicos e em vários territórios. No entanto, jazidas contendo minérios de alta qualidade, com características tecnológicas para o desenvolvimento de minas e para 0 aproveitamento na siderurgia, são menos comuns. Essas jazidas foram acumuladas pela ação de processos geológicos que atuaram na gênese do minério e tornaram-se minas diante das condições econômicas e logísticas para a produção. A existência dessas condições justifica os números da produção de volumes de minérios em alguns poucos países: apenas China, Brasil e Austália produzem mais de $50 \%$ do total mundial de minério de ferro [21].

Quanto ao teor de Fe contido nos minérios, os minérios de ferro podem ser divididos em duas categorias [21]:

- Os de baixo teor, contendo entre $35-40 \%$ de Fe ou menos.

- E os minérios de alto teor, contendo $60 \%$ de Fe, aproximando-se do conteúdo estequiométrico do mineral hematita.

Outra classificação existente dos minérios de ferro é em relação a sua distribuição granulométrica. Os tipos principais de acordo com a granulometria são [21]:

- Minério granulado, $>6 \mathrm{~mm}(1 / 4 \mathrm{pol})$, máximo de $10 \%<6 \mathrm{~mm}$

- Minério fino para sinterização ou sinter feed, $<6 \mathrm{~mm}>0,1 \mathrm{~mm}$, máximo de $20 \%<0,1 \mathrm{~mm}$.

- Minério fino para pelotização ou pellet feed, $<0,1 \mathrm{~mm}$, dentre outros tipos.

A Tabela 3 mostra dados sobre as reservas mundiais de minério de ferro por país em 2010 [22]. 
Tabela 3: Reservas mundiais de minério de ferro por país em 2010 [22].

\begin{tabular}{cccc}
\hline País & $\begin{array}{c}\text { Reservas } \\
\left(\mathbf{1 0}^{\mathbf{9}} \mathbf{~ d e ~} \mathbf{~}\right)\end{array}$ & $\begin{array}{c}\text { Minério contido } \\
\left(\mathbf{1 0 ^ { 9 }} \mathbf{~ d e ~} \mathbf{~}\right)\end{array}$ & $\begin{array}{c}\text { Teor médio } \\
(\mathbf{\%} \mathbf{~ F e})\end{array}$ \\
\hline Estados Unidos & 6,9 & 2,1 & 30,4 \\
\hline Austrália & 24 & 15 & 62,5 \\
\hline Brasil & 29 & 16 & 55,2 \\
\hline Canadá & 6,3 & 2,3 & 36,5 \\
\hline China & 23 & 7,2 & 31,3 \\
\hline Índia & 7 & 4,5 & 64,3 \\
\hline Iran & 2,5 & 1,4 & 56,0 \\
\hline Kazaquistão & 8,3 & 3,3 & 39,8 \\
\hline Mauritania & 1,1 & 0,7 & 63,6 \\
\hline México & 0,7 & 0,4 & 57,1 \\
\hline Rússia & 25 & 14 & 56,0 \\
\hline Africa do Sul & 1 & 0,6 & 60,0 \\
\hline Suécia & 3,5 & 2,2 & 62,9 \\
\hline Ucrânia & 30 & 9 & 30,0 \\
\hline Venezuela & 4 & 2,4 & 60,0 \\
\hline Outros Países & 11 & 6,2 & 56,4 \\
\hline Total mundial & $\mathbf{1 8 0}$ & $\mathbf{8 7}$ & $\mathbf{4 8 , 3}$ \\
\hline
\end{tabular}

\subsection{Os Gases}

O hidrogênio é um elemento comum encontrado em todos os combustíveis fósseis e toda matéria orgânica. Em sua forma pura molecular $\left(\mathrm{H}_{2}\right)$, o hidrogênio é um gás incolor, inodoro e não tóxico. Como petróleo e gás natural, o hidrogênio pode ser transportado através de gasodutos ou transportado em cilindros. Quando queimado, o hidrogênio produz zero emissão além de vapor de água. Isto faz com que seja um combustível final limpo [23]. 
O hidrogênio é o gás mais leve e também o combustível mais denso em energia por massa. $O$ gás de hidrogênio não ocorre naturalmente na Terra, entretanto pode ser produzido em uma variedade de maneiras [29].

Atomicamente pequeno e de alta difusividade, o hidrogênio tem sido observado como um redutor mais rápido em uma perspectiva de processos de redução rápida desprovido de emissões de gases de efeito estufa.

\subsection{Técnicas de redução para a obtenção de ferro metálico}

A redução de minérios de ferro para a obtenção do ferro metálico é a base para a fabricação de aço. Dentre as técnicas empregadas para a redução, o alto-forno é a técnica que responde pela maior parte da produção de ferro metálico. Outras técnicas utilizadas são as técnicas de redução direta, as técnicas de fusão redução e a técnica de eletrólise em escala de laboratório [13].

Dentre as técnicas para a obtenção de ferro metálico, se destacam o alto-forno e os processos de redução direta. A Figura 4 compara as tecnologias atuais para a produção aço a partir do ferro reduzido diretamente (ferro esponja sólido (DRI) ou ferro briquetado a quente (HBI)), ferro-gusa e sucata de aço, no que diz respeito à composição do gás redutor considerando emissões de $\mathrm{CO}_{2}$ por tonelada de aço líquido [24,25, 26, 27].

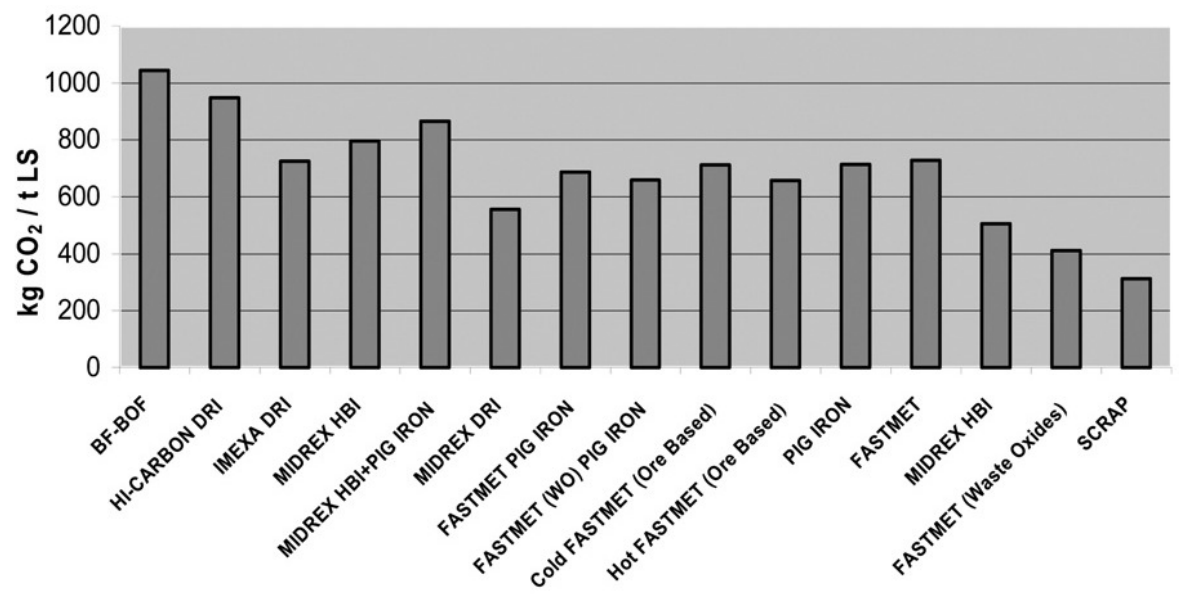

Figura 4: Emissões de $\mathrm{CO}_{2}$ com tecnologias siderúrgicas atuais [28]. 
Existem processos comerciais de redução direta de minério de ferro que utilizam como gás redutor o gás natural reformado [29]. Os processos de reforma utilizados para a redução direta podem ser divididos em: reforma por oxidação parcial e reforma catalítica. O processo de reforma catalítica é dividido em três categorias: reforma catalítica com vapor, reforma in situ e reforma no reator de redução [29]. A emissão de $\mathrm{CO}_{2}$ na produção de aço com base em ferro obtido por redução de minério de ferro por hidrogênio é diminuído, mas não completamente eliminado. Atualmente, a produção de aço não pode depender plenamente da redução direta de minério por hidrogênio por causa do custo do hidrogênio como agente redutor [28].

A seguir será mostrado o processo do alto-forno sem muito aprofundamento, pois este não é o objetivo desta tese. Em outra seção será apresentado os processos de redução direta utilizados industrialmente e os processos em escala de laboratório e escala piloto disponível na literatura [13, 29]. São apresentados também os processos que estão em fase de pesquisa como o processo de eletrodeposição [30].

\subsubsection{O Alto-forno}

A produção de ferro-gusa líquido para a produção de aço é dominado mundialmente pelo processo de alto-forno. Isso se deve a sua eficiência energética, capacidade de produção e evolução tecnológica [31].

O alto-forno produz ferro-gusa em estado líquido através do processo de redução de óxidos de ferro [32 33]. No alto forno a carga (sólidos e liquido) possui um movimento descendente e os gases um movimento ascendente. Conforme as etapas que ocorrem dentro do alto forno, este pode ser dividido em zonas granular, coesiva, de gotejamento e de combustão [34 35]. Os produtos deste reator são ferro gusa, escória e gases oriundos das reações de redução. Utiliza-se como redutor e combustível o coke ou carvão vegetal podendo se usar também carvão vegetal pulverizado e gases combustíveis além dos combustíveis e redutores emprega-se também fundentes [36,37].

A carga de minérios de ferro, conforme sua geometria e forma física pode ser classificada em minério bitolado, sinter feed e pelotas [35]. A Figura 5 
mostra partes do alto forno, movimento da carga e dos gases e exemplos das possíveis cargas.

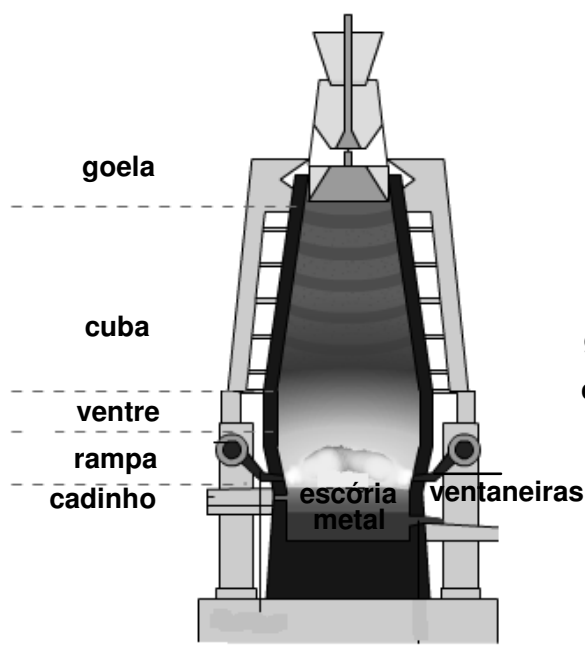

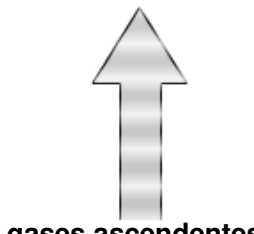

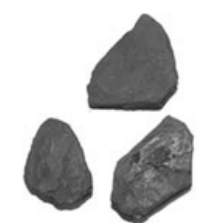

carga descendente

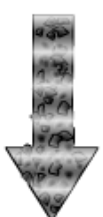

minério bitolado: $10-30 \mathrm{~mm}$$$
10-30
$$

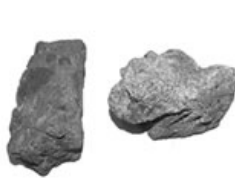

coque: $25-70 \mathrm{~mm}$ sinter: 5-50 $\mathrm{mm}$
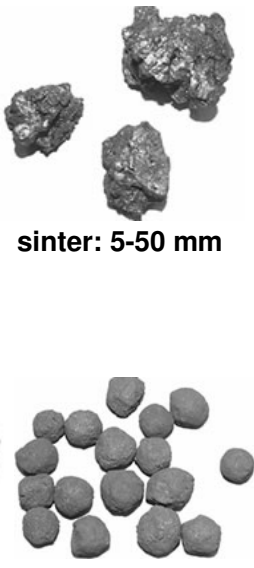

pelotas: $10-25 \mathrm{~mm}$

Figura 5: Partes do alto forno, movimento da carga e dos gases e exemplos das possíveis cargas [34].

\subsubsection{Processos de redução direta}

$\mathrm{Na}$ literatura [38, 39, 40], a classificação operacional dos processos de redução direta podem ser conforme o tipo de forno.

Nos processos de redução direta, a redução dos óxidos de ferro ocorrem no estado sólido, ou seja abaixo da temperatura de fusão do ferro puro (1535 $\left.{ }^{\circ} \mathrm{C}\right)$, utilizando hidrocarbonetos gasosos e ou materiais que contenham carbono [29].

Uma variedade de métodos tem sido proposta, mas a maioria deles não passou da fase de laboratório. Bogdandy e Engell comentam que os possíveis métodos de reducão de minérios de ferro podem ser examinados, considerando os seguintes aspectos [41]: 
1) A conversão possível por unidade de tempo e em unidade de volume ou unidade de seção transversal do espaço de reação. Esta quantidade determina o tamanho das instalações necessárias e, portanto, também o investimento e manutenção.

2) A utilização térmica e química do combustível ou gás redutor utilizado. Isso determina os custos de combustível por tonelada de ferro.

3) Os diferentes tipos de fonte de energia que podem ser utilizados, por exemplo, carvão, óleo combustível pesado, óleo leve, gás natural, energia elétrica. Isso determina se um determinado processo poderá ser usado com as fontes de energia disponíveis localmente.

4) Os diferentes graus de minério que podem ser usados, por exemplo, rico ou pobre em ganga, minério granulado, finos, pelotas, sinter, briquetes.

O ferro obtido pelos processos de redução direta ou DRI que surge da sigla em inglês para Direct Reduction Iron é um sólido a metalizado que ainda contém escória. Devido ao fato de que, durante o processo de redução direta apenas o oxigênio inerente às ações de alimentação de óxido de ferro é removido do sistema, o DRI produzido é poroso[29].

Um tipo de classificação dos processos de redução direta citada na literatura [29] é a seguinte:

- Processos com gás redutor gerado externamente ao forno de redução. Este pode ser subdividido nos processos: Forno de eixo vertical (Midrex, Processo HYL e Purofer) e Processos em Leito Fluidizado (Fior/FINMET, Iron Carbide e Circored).

- Processos com gás obtido a partir do carvão, gerado externamente ao forno de redução. Existem os processos que utilizam forno rotativo (Krupp-CODIR, SL/RN, DRC, ACCAR/OSIL); forno com soleira rotativa (Kinglor-Melor, Fastmet, INMETCO).

- Processos de fusão redução (COREX, Direct Iron Smelting (DIOS), AISI Direct Steelmaking, Hismelt, Romelt, Cyclone Converter Furnace (CCF).

- Processos inativos de interesse acadêmico e histórico: (Hoganas Process, Wiberg-Soderfors Process, Sumitomo Dust Reduction Process 
(SDR), Sumitomo Pré-reduction Method Process (SPM), Processo

Kawasaki, Processo Nippon Steel e High Iron Briquette Process (HIB).

\subsubsection{Processos em reator vertical}

\section{Processo MIDREX e HyL III}

No processo em reatores verticais, os principais processos são 0 MIDREX e HyL III. Estes processos são responsáveis respectivamente por aproximadamente 59,7\% e 18,4\% da produção mundial de ferro esponja [43].

Geralmente, o gás redutor é constituído de uma mistura de $95 \% \mathrm{H}_{2}$ e CO [42]. Segundo Araújo, o gás redutor deve conter uma mistura de $53 \%$ de $\mathrm{H}_{2}$ e $34,5 \%$ de CO. Já para Cheeley [43] é desejável que a razão entre $\mathrm{H}_{2} / \mathrm{CO}$ seja maior 0,5 .

O gás é introduzido na parte inferior do reator, assim, o gás apresenta um fluxo ascendente dentro do reator. A carga, em contrapartida, apresenta um fluxo descendente. Ao encontrar com o gás em uma temperatura de aproximadamente 860 a $900{ }^{\circ} \mathrm{C}$, a carga é aquecida e reduzida.

A Figura 6 apresenta um fluxograma do processo MIDREX de redução [44].

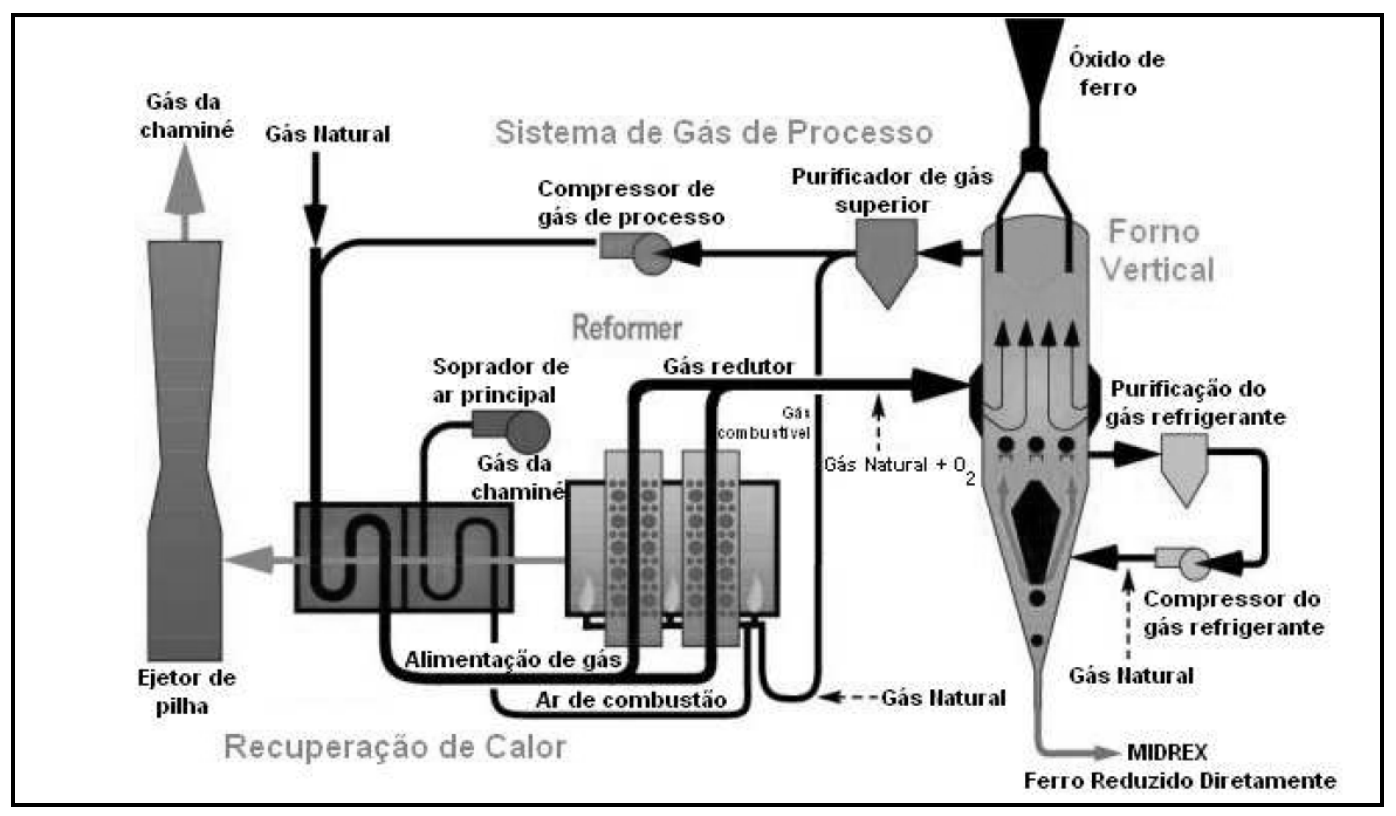

Figura 6: Fluxograma do Processo MIDREX [44]. 
O processo HyL III é responsável por $18,4 \%$ da produção mundial pelo método de redução direta [45].

O gás obtido na unidade de reforma tem como principais constituintes 0 $\mathrm{H}_{2}(74-76 \%), \mathrm{CO}(13-16 \%), \mathrm{CH}_{4}(4-5 \%)$ e $\mathrm{CO}_{2}(7-8 \%)$.

$\mathrm{O}$ gás redutor contendo principalmente $\mathrm{H}_{2}$ e $\mathrm{CO}$ é injetado no forno entre 900 a $950^{\circ} \mathrm{C}$, com pressão acima de $6,5 \mathrm{~atm}$. Este gás atravessa o forno em contracorrente à carga removendo o oxigênio e formando $\mathrm{H}_{2} \mathrm{O}$ e $\mathrm{CO}_{2}$. As reações são as mesmas que ocorrem no processo MIDREX. A Figura 7 apresenta o fluxograma do processo HyL III.

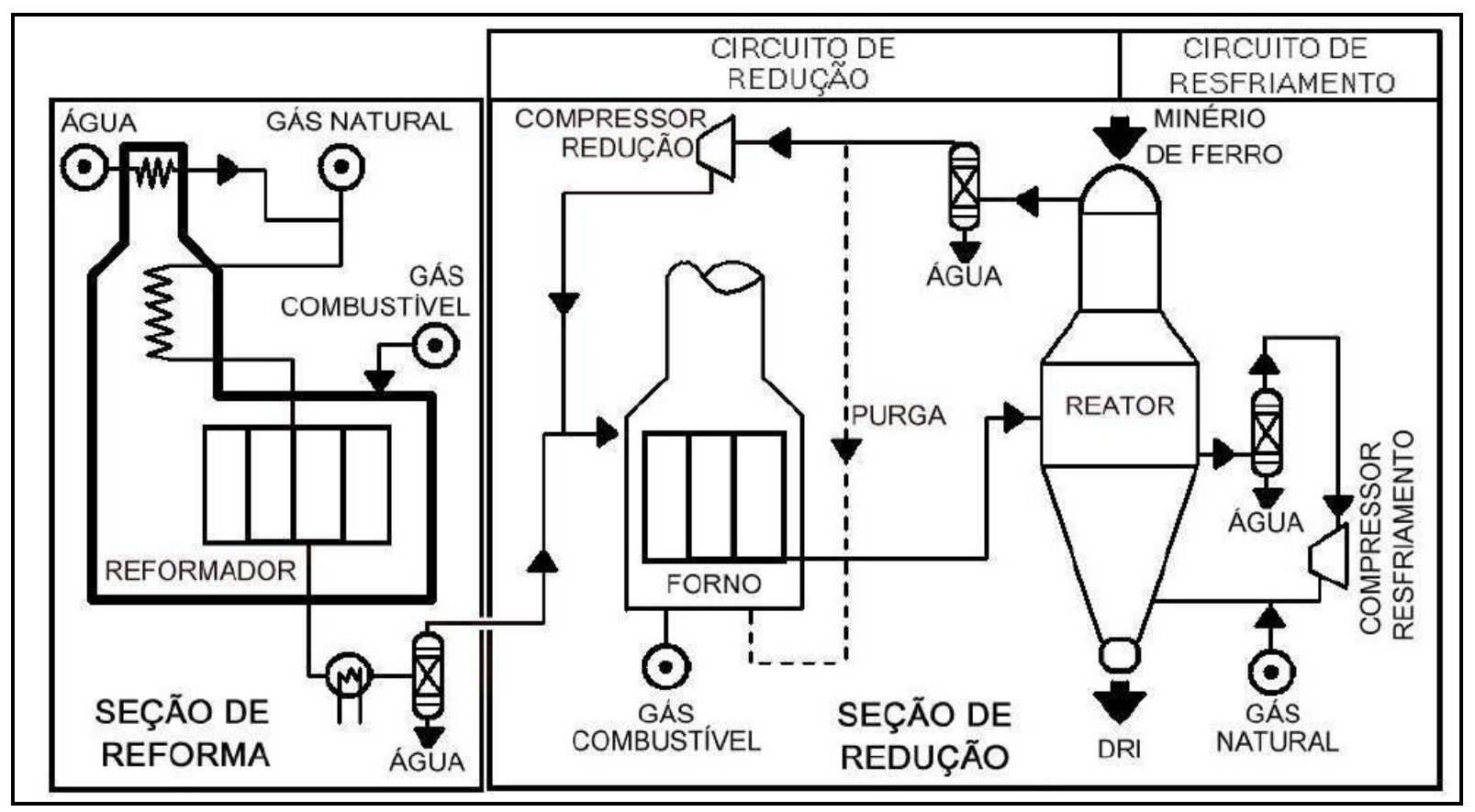

Figura 7: Fluxograma do Processo HyL III [42].

\section{Processo Purofer}

Neste processo o minério de ferro passa verticalmente para baixo em um forno, no qual flui um gás redutor quente em contra corrente ao sentido da carga contendo o minério de ferro. Sendo que o gás é usado tanto para aquecer quanto para reduzir a carga contendo o minério. $O$ gás redutor é gerado cataliticamente em geradores do tipo regenerativo. $O$ gás que sai do forno, e após sua purificação e resfriamento é usado parcialmente no aquecimento dos geradores de gás e parcialmente para a conversão do gás 
natural para o gás redutor, em uma temperatura em torno de $900-1000{ }^{\circ} \mathrm{C}$. Neste processo, o ferro metálico reduzido é descarregado quente e pode ser transportado para as aciarias em containeres ou para uma planta de briquetagem a quente $[42,13]$.

No processo Purofer, o forno de redução possui uma seção transversal retangular com cantos arredondados, as paredes do forno são forradas por refratários. Um sistema de duplo sino faz a alimentação do forno com pelotas e/ou minério granulado. Um funil no fundo é usado para extrair o produto em recipientes de aço selados, sem expor o produto ao ar [13].

\subsubsection{Processos em leito fluidizado}

Nesta seção são apresentados alguns aspectos dos processos realizados em leito fluidizado.

\section{Processo FIOR}

A Figura 8 mostra um fluxograma do processo FIOR.

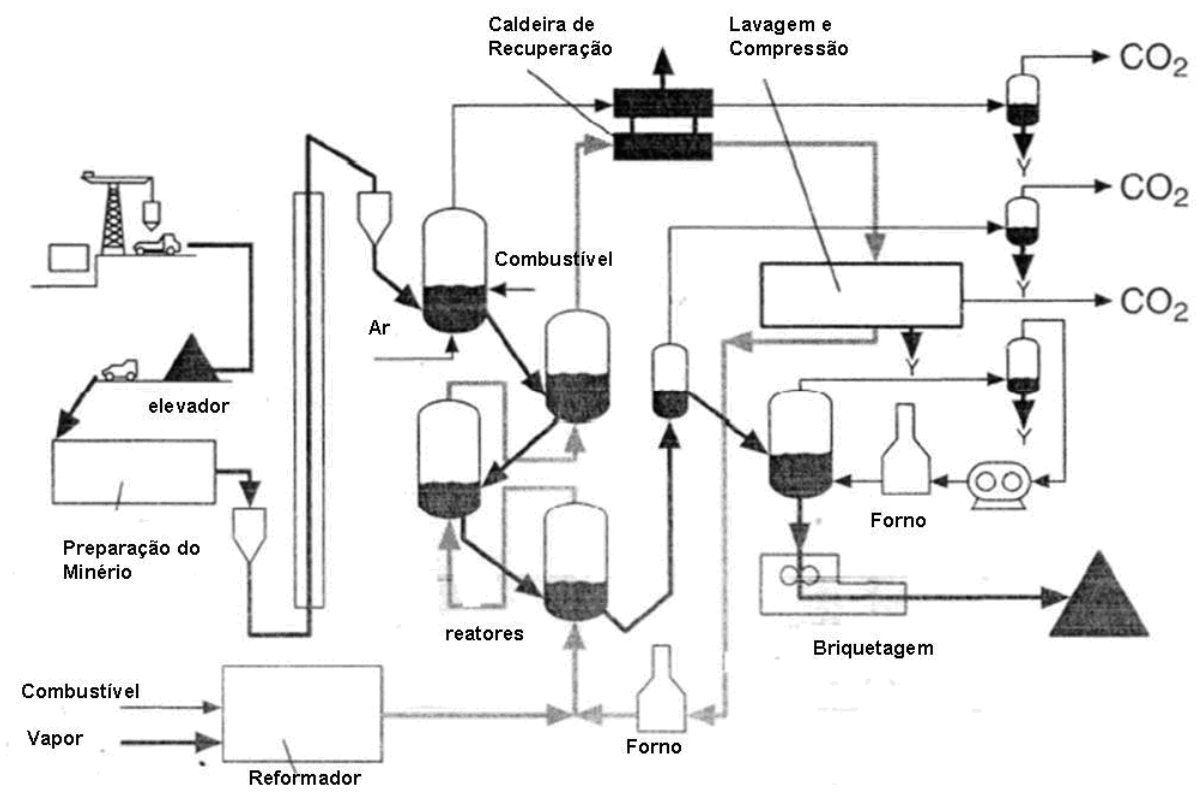

Figura 8: Fluxograma do processo de redução direta em leito fluidizado FIOR [42].

Os outros processos em leito fluidizado são semelhantes ao FIOR, mudando alguns aspectos operacionais. 
O nome FIOR vem do inglês (Fluid Iron Ore Reduction), o processo foi desenvolvido pela Esso Research and Engineering Company (ERE), o desenvolvimento deste processo começou em 1955. O processo FIOR é um processo de redução direta contínuo. É compreendido por quatro reatores de leito fluidizado em série, um reformador para produzir o gás de redução e uma seção de briquetagem. O minério de ferro (maioria menor que $5 \mathrm{~mm}$ ) é alimentado continuamente em um reator a aproximadamente $800{ }^{\circ} \mathrm{C}$ para a secagem e preaquecimento. A redução do minério ocorre em uma temperatura em torno de $700-750{ }^{\circ} \mathrm{C}$ em uma pressão de $10 \mathrm{~atm}$, alcançando $92 \%$ de metalização. $O$ gás de redução é produzido em um reformador catalítico com vapor a partir do gás natural. O processo FIOR teve sua primeira planta em escala industrial instalada em Puerto Ordaz na Venezuela e iniciou sua operação em 1976 [13].

\section{Processo FINMET}

O surgimento do processo FINMET foi a partir da parceria da indústria do processo FIOR na Venezuela em conjunto com a Voest-Alpine na Áustria e praticamente é uma evolução do processo FIOR. O desenvolvimento do processo FINMET teve como um dos principais objetivos, melhorar a eficiência energética do processo FIOR. Esse melhoramento se deve ao uso do gás de saída para aquecimento do minério a remoção do $\mathrm{CO}_{2}$ do gás reformado e também da reciclagem do gás. A planta do processo FINMET consiste de seção de secagem, reatores de redução, reformador de gás, sistema de reciclagem de gás e seção de manuseio de produto. Duas plantas industriais foram construídas, uma em Puerto Ordaz na Venezuela e outra em Port Hedland na Austrália [13].

\section{Processo Carboneto de Ferro}

Durante a década de 1970 foi desenvolvido o processo Carboneto de Ferro pelo Instituto de Pesquisa Hazen no Colorado, Estados Unidos. Neste 
processo, o carboneto de ferro é obtido a partir de finos de minério com tamanho de partículas variando entre $0,1-1,0 \mathrm{~mm}$ pré-aquecido. A redução ocorre em um circuito fechado, no qual o gás de processo é constituído por gás natural e gás que sai do reator de redução. Esse gás do processo contém $60 \%$ de $\mathrm{CH}_{4}, 34 \%$ de $\mathrm{H}_{2}, 2 \%$ de $\mathrm{CO}$ e $1 \%$ de $\mathrm{H}_{2} \mathrm{O}$. Durante o processo ocorre a redução de $\mathrm{Fe}_{2} \mathrm{O}_{3}$ para $\mathrm{Fe}_{3} \mathrm{O}_{4}$ para $\mathrm{Fe}$ com $\mathrm{CO}$ e $\mathrm{H}_{2}$, e em seguida ocorre a carbonização do $\mathrm{Fe}$ para $\mathrm{Fe}_{3} \mathrm{C}$ com o carbono do $\mathrm{CH}_{4}$ e $\mathrm{CO}$. A redução ocorre em uma temperatura variando entre $550-600{ }^{\circ} \mathrm{C}$ e a uma pressão de $1,8 \mathrm{~atm}$. $\mathrm{O}$ produto final contém $90 \%$ de $\mathrm{Fe}$ como $\mathrm{Fe}_{3} \mathrm{C}$, $8 \%$ de $\mathrm{Fe}$ como $\mathrm{FeO}$ e 6,2\% de C. O produto final é descarregado a uma temperatura em torno de $400{ }^{\circ} \mathrm{C}$ em seguida é transferido para um resfriador cilíndrico onde é resfriado com água para $70{ }^{\circ} \mathrm{C}$. Foi construída uma planta industrial em Trinidad em 1994, que fechou em 1999 [36, 13].

\section{Processo Circored e Circofer}

O desenvolvimento do processo Circored iniciou-se após os anos de 1970, inicialmente se desenvolveu na Suécia e em seguida na Alemanha. Os testes iniciais focavam o tratamento de resíduos de indústrias de aço. Após os anos de 1990, o interesse nesse processo despertou interesse e novos testes de simulação com finos de minério de ferro em escala piloto foram realizados. Também se obteve novos resultados e testes em outros reatores de leito fluidizado, que contribuíram para o desenvolvimento de uma planta de Circored em escala comercial [13].

Basicamente, o processo conta com dois reatores, sendo um reator de leito fluidizado circulante e outro reator de leito fluidizado. No reator de leito fluidizado circulante, o minério permanece por um tempo de 20-30 minutos e alcança cerca de 60 a $80 \%$ de redução. No reator de leito fluidizado ocorre a redução final no qual produto atinge $93 \%$ de metalização. Neste reator, o material permanece cerca de 2-4 horas, pois o reator opera com menores velocidades do gás, visto que nesta etapa final da redução as reações são predominantemente controladas por difusão [13, 42]. 
A primeira planta industrial que utiliza o processo Circored com capacidade de produção de 500.000 toneladas por ano de $\mathrm{HBI}$, foi instalada em Trinidad em 1998. O processo Circofer é semelhante ao processo Circored, o que os diferenciam é que o Circofer é baseado no carvão como fonte de energia. $O$ carvão é parcialmente queimado em um gaseificador/aquecedor e o semicoque é usado no reator de leito fluidizado circulante. O Circofer diferencia-se do Circored por possuir um absorvedor de $\mathrm{CO}_{2}$. Mas nenhuma planta comercial deste processo chegou a ser construída [13, 42].

\subsubsection{Processos em fornos rotativos}

Os fornos rotativos para a redução de minério de ferro consistem de um cilindro horizontal revestido em seu interior com refratários. A inclinação do forno é em torno de $3-4 \%$ em relação à horizontal, a carga constituída de carvão, fluxantes e óxido de ferro se movimenta no interior do forno devido a rotação do forno e a gravidade [13].

\section{Processo Krupp-CODIR Process}

Este processo das Indústrias Krupp, da Alemanha Ocidental, deriva do processo Krupp-Renn originalmente desenvolvido em 1930 para tratar de minério de alta sílica sem a adição de calcário, para produzir um produto aglomerado para posterior conversão em aço. O forno é alimentado continuamente com pelotas ou minério granulado com distribuição de tamanho controlada, dolomita e carvão. Esta carga é aquecida a uma temperatura de aproximadamente de $1000{ }^{\circ} \mathrm{C}$. O material oriundo do forno é então resfriado a uma temperatura em torno de $150{ }^{\circ} \mathrm{C}$ com água em um resfriador rotativo. $\mathrm{O}$ ferro metálico é então separado das cinzas e da dolomita por triagem e separação magnética. O material é então separado nas seguintes frações: 1) DRI maior que $5 \mathrm{~mm}$ que vai para o armazenamento; 2) a porção magnética menor que $5 \mathrm{~mm}$ e maior que $3 \mathrm{~mm}$ também para 0 armazenamento do produto final, enquanto que a porção não magnética é reciclada de volta no forno; 3) a porção magnética menor que $3 \mathrm{~mm}$ e maior que $1 \mathrm{~mm}$ é 
considerada DRI, já a fração não magnética é tratada para separação das cinzas do carvão; 4) a porção magnética menor que $1 \mathrm{~mm}$ de DRI é briquetado e a porção não magnética é descartada [42].

\section{Processo SL/RN}

Este processo teve como precursor o processo R-N, desenvolvido na Noruega primeiramente para recuperar $\mathrm{TiO}_{2}$ de minérios contendo titânio e ferro, para a produção de pigmentos. Em 1964, a Lurgi Chemie adquiriu a patente do processo R-N e em parceria com a Steel Company of Canadá Itda (Stelco) surgiu o processo SL/RN. Este processo é muito semelhante ao processo CODIR, o que o difere é que no SL/RN o resfriamento é realizado de forma indireta o que exige um resfriador com um comprimento maior que o CODIR, mas por outro lado não há a perda de 0,5-1 \% da metalização como ocorre no CODIR $[13,42]$.

\section{Processo DRC}

A sigla DRC surge a partir do nome Direct Reduction Corporation, este processo surgiu após esforços terem sido feitos para o desenvolvimento de um processo para produzir rutilo sintético através da redução com carvão de óxido de ferro em ilmenita, e seguido de lixiviação do ferro metalizado do dióxido de titânio. A faixa granulométrica dos minérios de ferro variam de $5-20 \mathrm{~mm}$. $O$ processo requer também carvão com alta reatividade e calcário utilizado como agente de dessulfuração. Além do DRI, o processo produz também energia elétrica, que é produzida com a utilização dos gases de exaustão [13].

\section{Processo ACCAR/OSIL}

Este processo também é semelhante aos outros processos que utilizam fornos rotativos. O ACCAR (Allis-Chalmers Controlled Atmosphere Reactor) 
produz DRI em um forno rotativo com atmosfera controlada. Pode utilizar combustível sólido, líquido ou gasoso, unicamente ou em combinação. Estes podem ser utilizados diretamente no forno. $O$ forno possui válvulas arranjadas radialmente à circunferência do forno e espaçadas uniformemente ao longo do comprimento do forno. Estas válvulas permitem a injeção de combustível gasoso ou líquido [13, 42].

\section{Outros processos com fornos rotativos}

Existem outros processos que utilizam forno rotativo, estes processos são semelhantes aos anteriores no que diz respeito a equipamento, matéria-prima e questões operacionais. Estes processos são Processo SIIL, Hindustan EletroGraphites Ltda, Kumar Metallurgicals Ltda, Raipur Alloys Ltda, Aceros Arequipa e Processo DAV [13, 42].

\subsubsection{Tecnored}

O processo Tecnored visa a produção de ferro gusa líquido. O processo é brasileiro. O processo tem como base a obtenção de ferro gusa a partir da redução de pelotas ou briquetes autoredutores. As pelotas ou briquetes são produzidos a partir de finos de minério, finos de carvão mineral, vegetal ou coque e aglomerante hidrotérmico. [31,46, 47, 48].

O forno do processo Tecnored, possui a geometria de uma cuba vertical. A alimentação das pelotas autoredutoras é realizada pela parte central superior [31, 46]. O combustível (carvão vegetal, carvão mineral ou coque) também é alimentado pela parte superior do forno. O combustível forma um leito permeável. As pelotas são reduzidas e fundidas pelos redutores contido nas pelotas e calor gerado na combustão do carvão ou coque respectivamente. Através de ventaneiras é soprado ar para a queima do combustível. O ferro gusa líquido permea através do leito de combustível e é coletado na parte inferior onde é separado da escória [46, 47, 48]. 


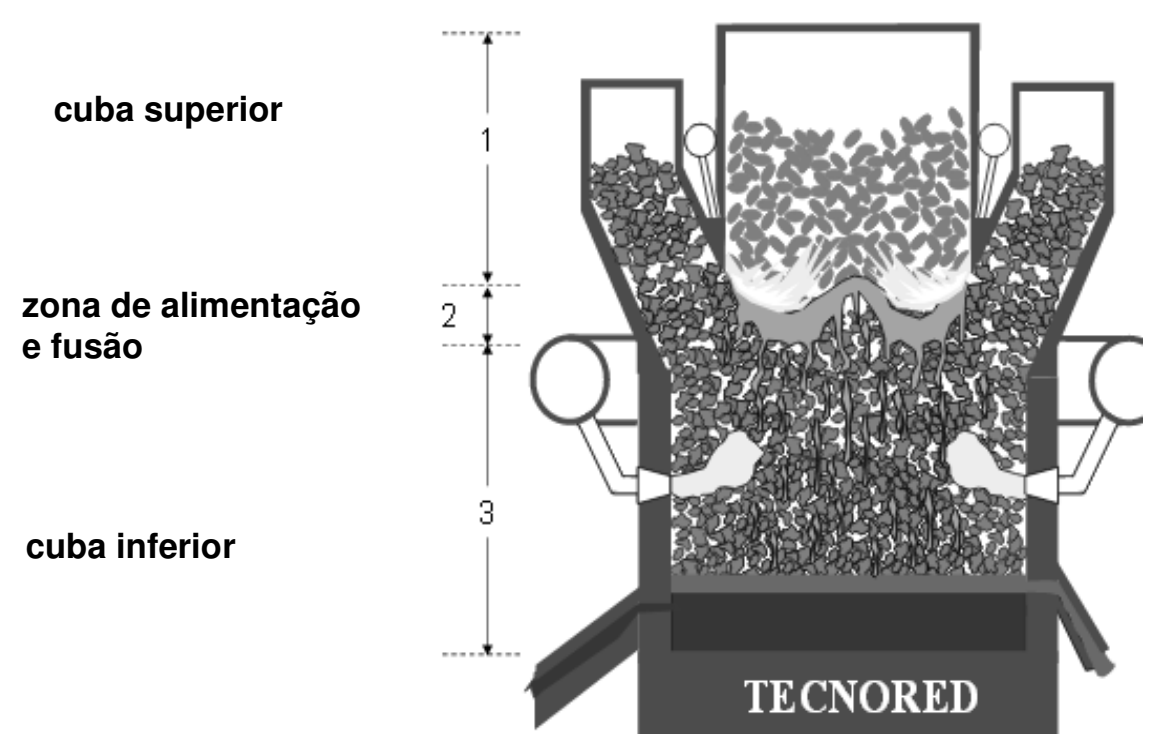

Figura 9: Seção transversal do Forno Tecnored [49].

\subsubsection{Processo de eletrólise}

Processos de eletrólise são apenas citados nesta seção, pois o enfoque desta tese será a redução direta por hidrogênio. Os processos de eletrólise de óxidos de ferro têm sido citados na literatura [50,51, 52] como uma forma alternativa para a obtenção de ferro.

É citado o processo realizado em meio alcalino com $\mathrm{NaOH}$ a temperatura de $114{ }^{\circ} \mathrm{C}$ e outras condições específicas. A eletrodeposição em um meio com muitos sais no qual o óxido de ferro está fundido.

\subsubsection{Números da produção de ferro}

Alto-forno tem sido o principal instrumento para a conversão do minério de ferro em ferro gusa e deverá continuar a ser o pilar da indústria siderúrgica por mais 30 anos. No entanto, o setor siderúrgico tem estudado novos processos para tentar diminuir os danos causados ao meio ambiente além dos custos com energia. No final da década de 1970, Venezuela, México e outros países com excedente de gás natural começaram a fazer quantidades significativas de DRI. Desde então, DRI tornou-se um substituto competitivo para a sucata. Em 1990, o mundo produziu 29,37 milhões de toneladas métricas de DRI, com grau de metalização variando $90 \%$ a $94 \%$ de $\mathrm{Fe}$. As 29 
milhões de toneladas de DRI ficam muito aquém dos 500 milhões de toneladas de ferro-gusa a ser produzido anualmente pelo processo que utiliza 0 alto-forno, mas uma série de outras tecnologias promissoras estão em desenvolvimento que poderiam ajudar a preencher a lacuna [5].

Uma estimativa sobre o cenário para a produção de aço para daqui a 50 anos é mostrada na Figura 10.

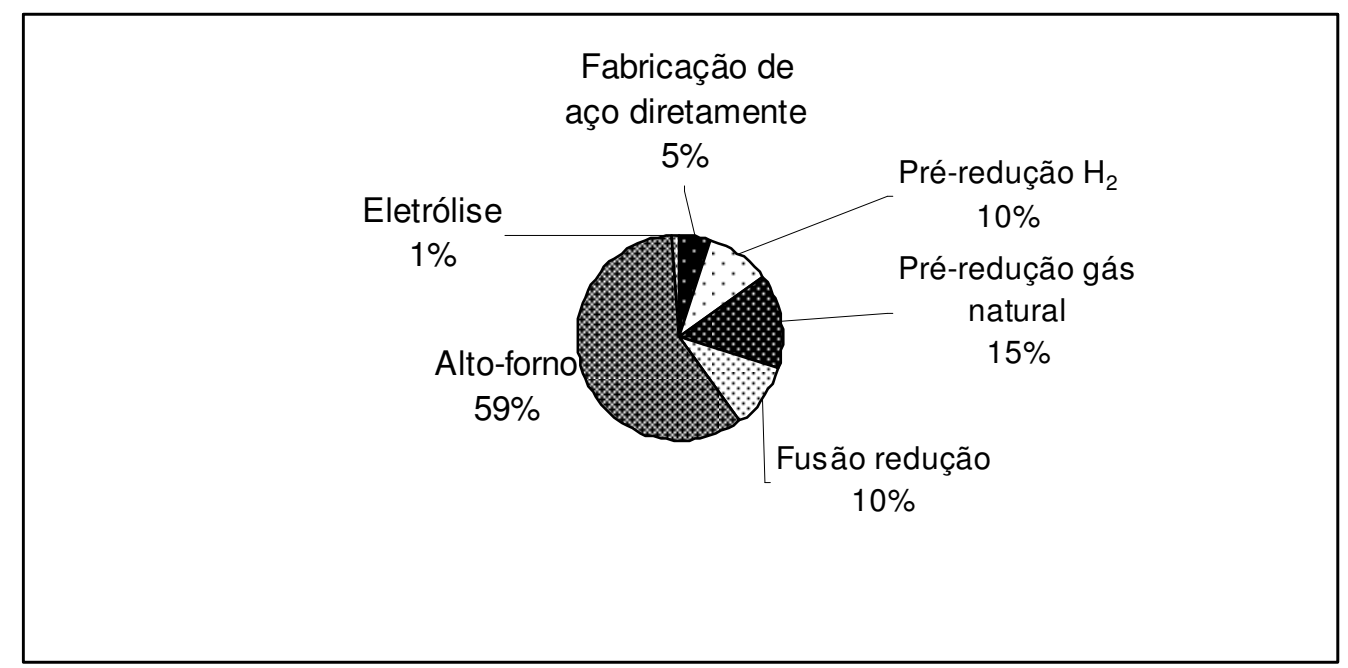

Figura 10: Previsão do cenário de produção de aço daqui a 50 anos [5].

\subsection{Processos de aglomeração de minérios de ferro}

Os processos de aglomeração de minérios de ferro visam transformar os finos em aglomerados para serem utilizados nos processos de redução. Os processos de aglomeração aplicados em processos de fabricação de ferro primário são a sinterização, briquetagem e pelotização [11, 13].

O processo de pelotização produz pelotas com o formato de esferas com tamanhos variando entre 10 e $15 \mathrm{~mm}$. Os finos de minérios juntamente com aditivos são alimentados em discos ou tambores pelotizadores onde são aglomerados com a adição ou não de água e a adição ou não de aglomerantes. As pelotas são produzidas com tamanhos específicos. As pelotas verdes que saem dos discos ou tambores são submetidas a tratamentos térmicos onde são secas, aquecidas, queimadas e resfriadas para adquirirem propriedades específicas [11, 13]. 


\subsection{Termodinâmica}

A reação química global de redução de óxido de ferro por hidrogênio ou monóxido de carbono está escrito como [41]:

$$
\mathrm{FeO}_{n}+n\left(\mathrm{CO}, \mathrm{H}_{2}\right) \rightarrow \mathrm{Fe}+n\left(\mathrm{CO}_{2}, \mathrm{H}_{2} \mathrm{O}\right)
$$

A Figura 11 mostra parte do diagrama de fases Fe e $O$. Nota-se que a fase wustita é estável acima de $570{ }^{\circ} \mathrm{C}$. Infere-se que a partir da redução da hematita, pode haver a presença da fase wustita durante a redução somente em temperaturas acima de $570{ }^{\circ} \mathrm{C}$. Supondo um modelo de redução da hematita por hidrogênio, tem-se os seguintes caminhos:

$$
\begin{gathered}
T \leq 570 \mathrm{C}:\left\{\begin{array}{l}
3 \mathrm{Fe}_{2} \mathrm{O}_{3(s)}+\mathrm{H}_{2(g)}=2 \mathrm{Fe}_{3} \mathrm{O}_{4(s)}+\mathrm{H}_{2} \mathrm{O}_{(g)} \\
\mathrm{Fe}_{3} \mathrm{O}_{4(s)}+4 \mathrm{H}_{2(g)}=3 \mathrm{Fe}_{(s)}+4 \mathrm{H}_{2} \mathrm{O}_{(g)}
\end{array}\right\} \quad \text { Equação } 1 \\
T>570 \mathrm{C}:\left\{\begin{array}{l}
3 \mathrm{Fe}_{2} \mathrm{O}_{3(s)}+\mathrm{H}_{2(g)}=2 \mathrm{Fe}_{3} \mathrm{O}_{4(s)}+\mathrm{H}_{2} \mathrm{O}_{(g)} \\
\mathrm{Fe}_{3} \mathrm{O}_{4(s)}+\mathrm{H}_{2(g)}=3 \mathrm{Fe} \mathrm{O}_{(s)}+\mathrm{H}_{2} \mathrm{O}_{(g)} \\
\mathrm{FeO} \mathrm{O}_{(s)}+\mathrm{H}_{2(g)}=\mathrm{Fe}_{(s)}+\mathrm{H}_{2} \mathrm{O}_{(g)}
\end{array}\right\} \quad \text { Equação } 2
\end{gathered}
$$




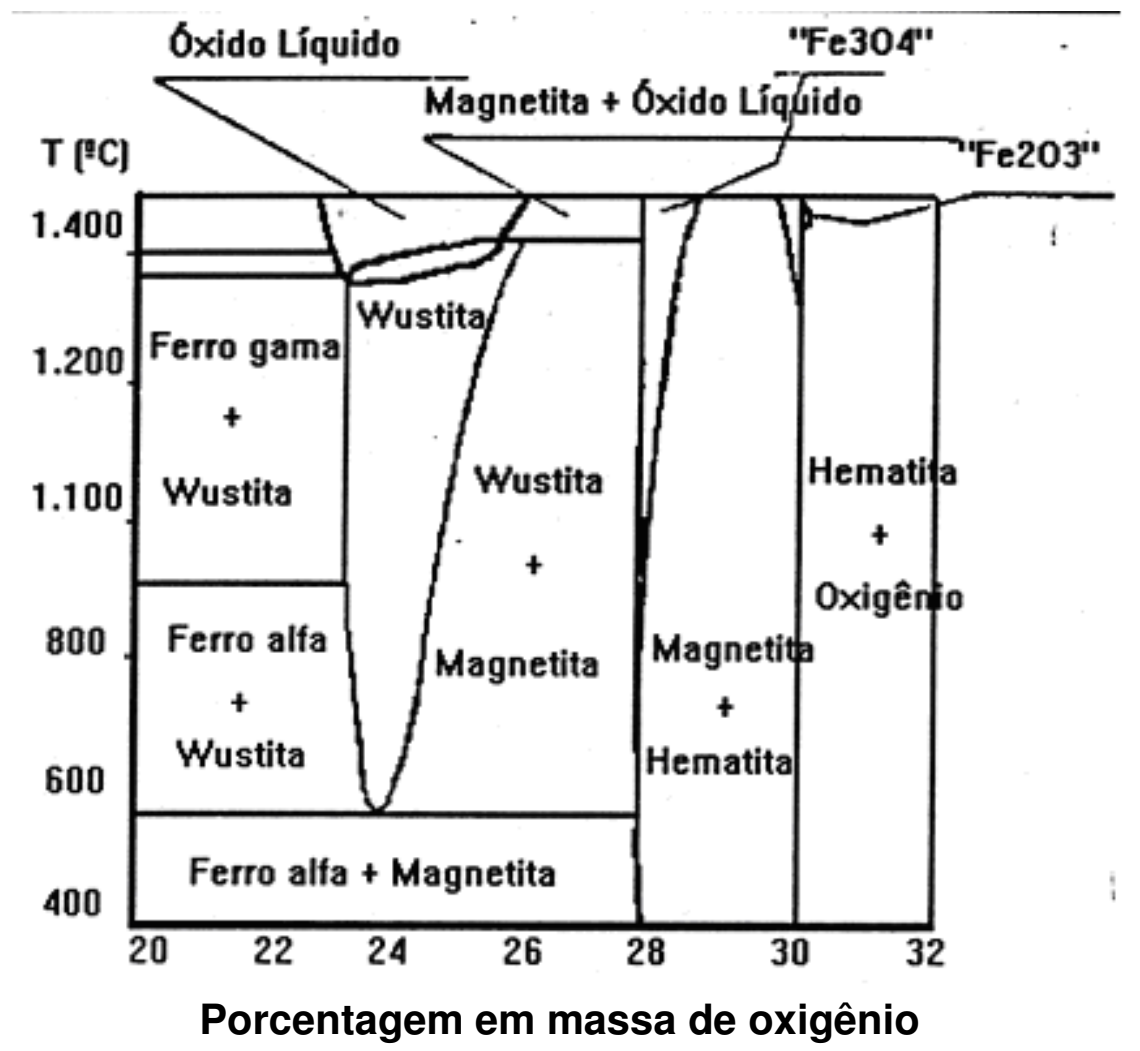

Figura 11: Parte do diagrama de fases do sistema Fe e O [41].

Cada etapa é um equilíbrio heterogêneo influenciado não só pela temperatura, mas também pela composição do gás $\left(\left(\mathrm{H}_{2} \mathrm{O}\right.\right.$ e $\left.\mathrm{H}_{2}\right)$ e $\left(\mathrm{CO}_{2}\right.$ e $\left.\left.\mathrm{CO}\right)\right)$ $[117,118]$.

A reação de redução de um óxido pode ser influenciada pelo teor de água presente no gás reativo. O diagrama da Figura 12 mostra as áreas de estabilidade de vários óxidos como uma função da temperatura e gases oxidantes [118, 119, 121]. 


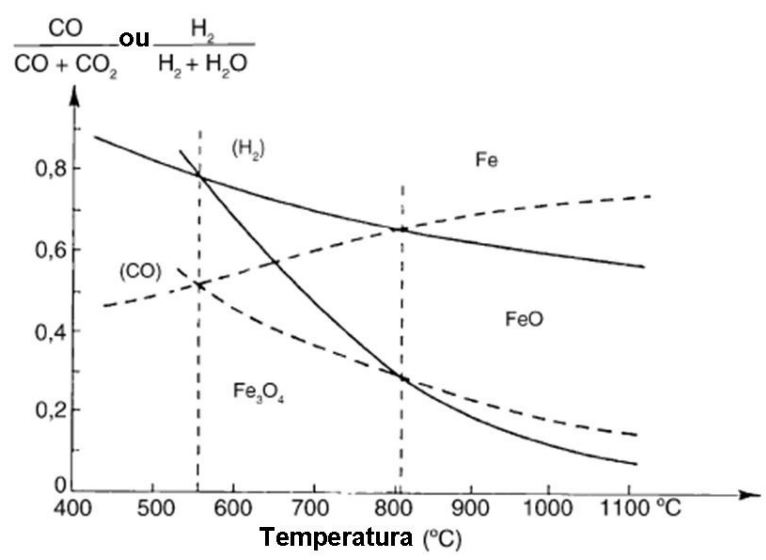

Figura 12: Diagrama de equilíbrio dos diferentes óxidos de ferro como uma função da composição do gás para Fe-C-O e Fe-H-O em equilíbrio a 1 atm [118]

Uma comparação da redução de óxidos de ferro por $\mathrm{H}_{2}$ e $\mathrm{CO}$ é necessária. A sobreposição das curvas com $\mathrm{CO}$ e $\mathrm{H}_{2}$ mostra que a redução por hidrogênio é termodinamicamente favorável acima de $800{ }^{\circ} \mathrm{C}$ [118].

No entanto, do ponto de vista térmico, deve-se notar que a reação de redução da wustita por hidrogênio é endotérmica, enquanto que com CO é exotérmica [118]. Para conduzir a redução industrial de minério de ferro por hidrogênio, este deve ser queimado para fornecer a energia necessária para atingir a temperatura desejada para a redução, e também o hidrogênio será o agente redutor [41].

\subsection{Cinética da reação}

A redução da hematita por hidrogênio e hidrogênio mais monóxido de carbono envolve vários óxidos e, portanto, várias reações intermediárias [53, 54]. Cada uma dessas reações é uma reação gás-sólido e como tal, possui várias etapas. A cinética da reação pode ser diferente, pois esta pode depender da morfologia das amostras, temperatura, composição do gás [55, $56]$.

Afim de realizar uma investigação sobre a cinética de redução, é necessário fazer uma citação sobre as etapas de uma cinética de reação gás sólido. E em seguida é comentado sobre a redução de hematita para ferro 
metálico como um todo. Dando um enfoque maior para a redução da wustita. Pois esta é citada como a etapa mais lenta [41].

\subsubsection{Fases de uma reação gás-sólido}

Para o seu desenvolvimento, uma reação gás-sólido envolve uma sucessão de etapas de reação e/ou de transporte de material [41]. As etapas são: o transporte do reagente de fase gasosa para a superfície do sólido: Difusão externa (1), transporte do reagente nos poros do grão: difusão interna (2), a quimissorção do reagente à superfície sólida (3), reação química na superfície (4), a dessorção da superfície (5), distribuição interna do produto (6) e o alcance do produto (7). Estas etapas estão ilustradas na Figura 13.
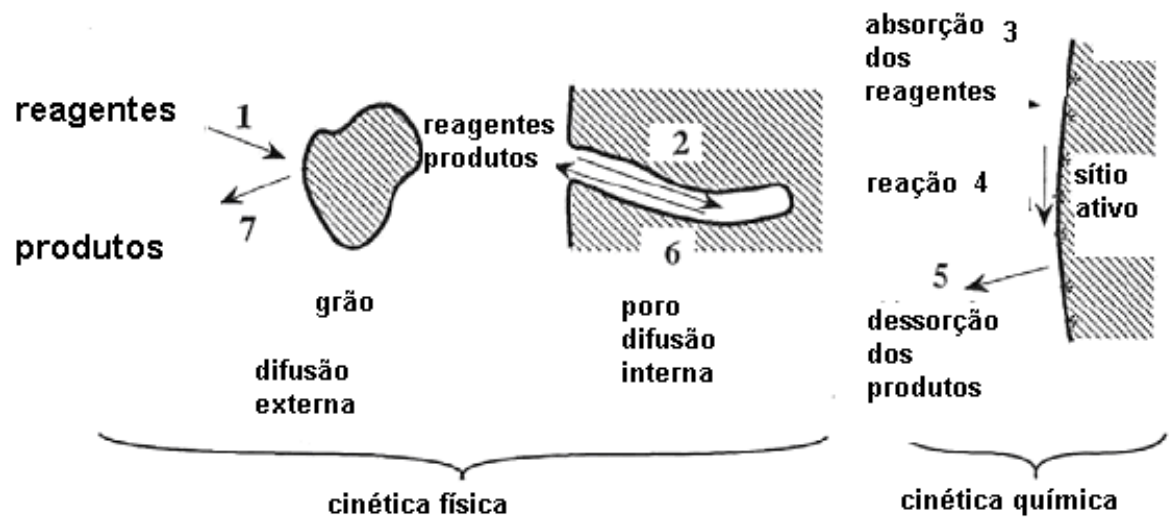

Figura 13: Representação das etapas de uma reação gás-sólido [41].

$\mathrm{Na}$ presença de um produto sólido, forma-se uma camada densa, a reação será realizada através de uma etapa adicional de difusão de uma espécie através do produto sólido [41].

\subsubsection{Redução da hematita}

Entre os estudos sobre a cinética da redução global de hematita para ferro e da determinação dos passos limitantes estão Turkdogan e Vinters [57, 60], Pescott [58], Pineau, Kanari e Gaballah [117, 118]. 
Turkdogan e Vinters $[57,60]$ estudaram a taxa de redução de partículas de minério de hematita de vários tamanhos e para temperaturas variando de 200 a $1200{ }^{\circ} \mathrm{C}$ em intervalos de $100{ }^{\circ} \mathrm{C}$ e para diferentes tamanhos de partículas. Turkdogan e Vinters mostram que a taxa de reação diminui à medida que o tamanho das partículas aumenta. Eles também mostram que, se o ferro formado é poroso, existem três processos básicos que controlam a resposta a diferentes graus de progresso e sob certas condições experimentais

Para temperaturas menores que $500{ }^{\circ} \mathrm{C}$ ou para pequenas partículas menores que $4 \mathrm{~mm}$, a reação é limitada pela velocidade de reação química. Isso ocorre porque a difusão nos poros tem pouca resistência e a concentração de hidrogênio é, portanto, quase homogênea [57]. Para temperaturas maiores que $800^{\circ} \mathrm{C}$ ou partículas maiores que $8 \mathrm{~mm}$ é a difusão gasosa de hidrogênio nos poros da camada de ferro formada que limita a reação [57]. Em condições intermediárias, é um regime misto, que limita a velocidade da reação [57].

Os autores mostram que a difusão através da camada de ferro desempenha um papel importante na determinação da taxa de reação a estas temperaturas. Para partículas de minério menor que $1 \mathrm{~mm}$, uma desaceleração significativa na reação aparece no final a uma temperatura de cerca de $700{ }^{\circ} \mathrm{C}$. Este fenômeno não é observado para partículas de tamanhos maiores [57].

Pescott [58] obteve a energia de ativação em diferentes estágios e em temperaturas entre 300 e $1100{ }^{\circ} \mathrm{C}$. Chegando as seguintes conclusões:

- Para temperaturas abaixo de $510^{\circ} \mathrm{C}$, a reação química interfacial limita a velocidade porque a energia de ativação é de cerca de $15 \mathrm{kcal} / \mathrm{mol}$, que é a ordem habitual de magnitude de tais processos a partir da literatura. Das observações microscópicas revelaram que a camada de ferro produzido era muito porosa a estas temperaturas. Isto é consistente com observações anteriores de Turkdogan e Vinters [57].

- A partir de $510-550{ }^{\circ} \mathrm{C}$, dependendo do grau de redução levados em conta, há uma mudança de ordens de magnitude de energia de ativação. De acordo com o autor até $30 \%$ e $50 \%$ da redução, o valor, cerca de $6 \mathrm{kcal} / \mathrm{mol}$ é típico de controle pela difusão de gás através dos poros dos produtos sólidos. 
- O valor médio da energia de ativação entre 710 e $910{ }^{\circ} \mathrm{C}$ é $48 \mathrm{kcal} / \mathrm{mol}$ e $103 \mathrm{kcal} / \mathrm{mol}$ entre 960 e $1110{ }^{\circ} \mathrm{C}$. Segundo o autor, o primeiro valor poderia corresponder à difusão em fase sólida de átomos de oxigênio através de uma camada de ferro alfa denso. A transição para uma limitação por difusão na fase sólida é devido ao desaparecimento dos melhores poros e o fechamento de outros poros. Isso, então, causa uma densificação da camada de ferro e uma diminuição na taxa de reação. $O$ autor não relata observações ou caracterizações da camada de ferro para apoiar esta conclusão. Como para a segunda desaceleração o autor atribui à passagem do ferro gama para ferro alfa. De fato, como observado anteriormente, a $912{ }^{\circ} \mathrm{C}$, o ferro sofre uma transformação alotrópica causando uma mudança na estrutura cristalina. Estas transformações alotrópicas causam difusão lenta, fenômeno que limita a reação em cerca de $900{ }^{\circ} \mathrm{C}$. Posteriormente, a temperatura aumenta, a difusão em fase sólida está se acelerando novamente.

\subsubsection{Redução da wustita}

A transformação da wustita para ferro é a última etapa da redução da hematita. Este é o passo mais lento do processo de reação. Muitas publicações têm como finalidade a cinética desta reação $[57,58,59,60,119,118]$. Gaballah et al. [59], em 1972, mediram a energia de ativação de redução de pós de wustita para temperaturas entre 680 e $900^{\circ} \mathrm{C}$, encontrando o valor de $48 \mathrm{kcal} / \mathrm{mol}$ que permaneceu constante durante a reação. De acordo com os autores a difusão de oxigênio através da camada densa de ferro foi a etapa limitante da reação.

Pescott [58], relata a existência de uma desaceleração da reação acerca de $900{ }^{\circ} \mathrm{C}$, que corresponde à transição alotrópica do ferro. $\mathrm{O}$ efeito da presença de água no gás reativo na cinética da reação também foi estudado. Nota-se que, em uma atmosfera seca, a desaceleração ocorre principalmente entre 800 e $900{ }^{\circ} \mathrm{C}$ e no final da reação. Observações de MEV mostraram que o abrandamento identificado na atmosfera com hidrogênio seco está 
relacionado com mudanças na textura do ferro formado que está se tornando mais e mais denso, passando, então, a atuar como uma barreira para a difusão de gás nos poros. A $700{ }^{\circ} \mathrm{C}$, parece que a amostra tem porosidade fina. Já a $890{ }^{\circ} \mathrm{C}$, os poros são menos e maiores, tornando a camada de ferro uma barreira densa. Esta evolução dos poros nos cristais densos de 100 a $500 \mu \mathrm{m}$ de acordo com a temperatura foi estudado quantitativamente por Turkdogan et al. [60] em 1971 com um porosímetro de mercúrio. Três parâmetros importantes foram utilizados no estudo: volume de poros que estão interligados, o raio dos menores poros interconectados e o raio crítico. A Figura 14 mostra micrografias da wustita após a redução de $75 \%$ em hidrogênio seco [59]
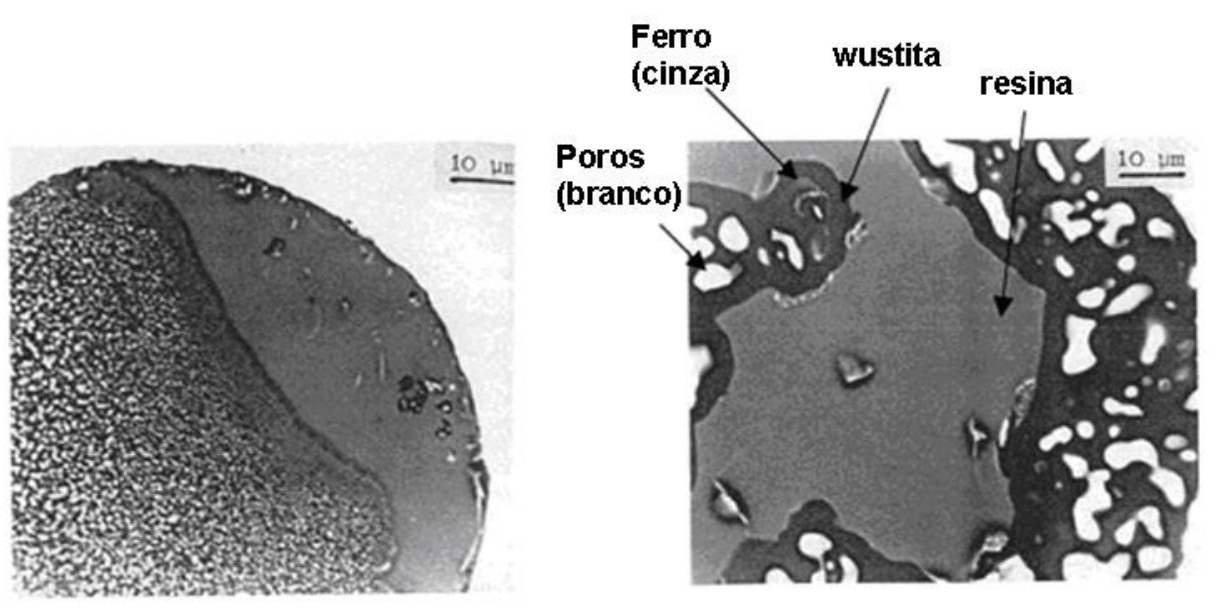

Figura 14: Micrografias da wustita após a redução de $75 \%$ em hidrogênio seco (à esquerda: $700{ }^{\circ} \mathrm{C}$, direita: $\left.890{ }^{\circ} \mathrm{C}\right)[61]$.

Os autores concluem que o número de poros diminui com a temperatura. Além disso, a densidade final das amostras para temperaturas utilizadas variam entre 2,1 e $2,9 \mathrm{~g} / \mathrm{cm}^{3}$, e que resulta em um volume de poros total entre 0,35 e $0,22 \mathrm{~cm}^{3} / \mathrm{g}$. O fato de os valores de $\mathrm{V}$ obtidos estarem próximos a estes valores, possibilitou aos autores concluirem que a maior parte dos poros presentes nas amostras estão interligados [58].

Em relação à desaceleração em atmosfera de hidrogênio úmido, o fenômeno é importante e ocorre no início da reação. As observações no MEV mostraram uma mudança na estrutura de poros de partículas relativamente 
semelhante à registrada em condições secas, exceto que os poros são ligeiramente maiores neste caso. A desaceleração não pode ser atribuída exclusivamente à textura do ferro. Os autores especulam que o vapor de água bloqueia os sítios ativos da wustita em que o hidrogênio absorve causando envenenamento da superfície e, portanto, uma redução substancial na taxa de reação [58]. Isto também foi observado e estudado por Hayes [61] em 1979.

A influência do tamanho das partículas de wustita é difícil de entender. Para partículas maiores, o tempo aumenta com a redução de tamanho de partícula, como observado por Turkdogan e Vinters [57] na redução de partículas de hematita. Ao contrário, estudando a redução a $1000{ }^{\circ} \mathrm{C}$ de diferentes frações de wustita pura como micropelotas, El-Geassy e Rajakumar e [62] mostraram um comportamento diferente.

Para tamanhos de 200, 300 e $400 \mu \mathrm{m}$, a taxa de reação aumenta quando partículas tornam-se menores, enquanto que para o tamanho de $100 \mu \mathrm{m}$, a velocidade diminui de repente [59]. Da mesma forma, Devisme [63], observou que para um tamanho de partícula de $100 \mu \mathrm{m}$, a redução por hidrogênio a $800{ }^{\circ} \mathrm{C}$ em um nano pó de hematita foi maior do que em um micro pó. Esta observação se deve à aglomeração que dificulta a difusão.

\subsubsection{Mecanismos e morfologias}

\subsubsection{Adesão de partículas}

O fenômeno de aderência de partículas tem algumas características para ocorrer principalmente durante a metalização do minério, algumas vezes acompanhado com ferro fibroso [64, 65]. Isto poderia ser influenciado principalmente pela temperatura, pelo tipo e pelo tamanho do minério de ferro, pelo conteúdo de ganga, pela etapa de redução e pela adição de hidrogênio à mistura de gás redutor. De acordo com Zhang [66], a tendência a adesão dependia fortemente datemperatura, a qual principalmente era afetada pelo minério e pelas propriedades do redutor.

A forma externa do minério de ferro afeta a adesão. Formas esferoidais possuem uma menor tendência a adesão comparada com formas angulares. [64, 67]. Minérios com maior quantidade de ganga levam a uma menor 
temperatura de fusão, que poderia levar a uma maior adesão. [64,68,69]. No aspecto de agente redutor, a estrutura de poros no ferro obtidas por redução de $\mathrm{CO}$ era mais grossa que na redução por $\mathrm{H}_{2}$. $\mathrm{O}$ resultado de pequenas adições de hidrogênio foi que o crescimento de ferro fibroso diminuía e parava se a adição de hidrogênio aumentava [64, 70, 71].

Três mecanismos diferentes de adesão foram comentados por várias investigações que estudaram a redução de minério de ferro $[65,70,72,73,74$, 75]. O primeiro tipo de adesão foi causada pelo ferro recem produzido e com energia de superfície elevada, resultando em força de aderência elevada entre partículas de minério de ferro reduzido. O segundo mecanismo de adesão foi conseqüência do crescimento de alguns whiskers de ferro sobre a superfície da partícula. $O$ terceiro mecanismo de adesão ocorreu acompanhado de uma fase líquida na zona de sobreaquecimento, o que pode ser estimulado pela presença de ganga, devido a fusão eutética de uma fase contendo $\mathrm{CaO}-\mathrm{SiO}_{2}-\mathrm{FeO}$, que causava o agrupamento das pelotas de minério de ferro.

\subsubsection{Aparecimento de fissuras e trincas em pelotas}

Uma explicação para o aparecimento fissuras e trincas em pelotas durantes a redução é proposta por Meyers e Tantevee [112], que realizaram uma análise de tensão em pelotas durante a redução e proporam uma teoria explicando o aparecimento das fissuras e trincas. Esta teoria está associada as mudanças de volume associadas com as mudanças estruturais nas transformações da hematita para magnetita e magnetita para wustita que ocorrem durante a redução [76]. Ocorrendo uma mudança de $11 \%$ no volume durante a mudança de hematita para magnetita [112]. Por cálculos e considerando o peso específico da hematita de $\left(6,85 \mathrm{~g} / \mathrm{cm}^{3}\right)$ e magnetita $\left(5,81 \mathrm{~g} / \mathrm{cm}^{3}\right)$ e calculando a mudança da densidade e considerando a mudança no volume devido à perda de oxigênio chega-se a uma diminuição no volume de 9,8\%. Já a transformação de wustita para ferro encontra-se por cálculos uma contração de $5 \%$ [112].

A Figura 15 mostra a análise das tensões devido as mudanças dimensionais da pelota. Aplicando-se a análise para a reação hematita- 
magnetita (reação topoquímica) da pelota de minério de ferro chega-se que o núcleo de hematita está sob tensão e a casca de magnetita está sob compressão. Esta análise pode ser extendida para outras reações envolvendo mudanças de volume, como a transformação de wustita para ferro.

Quando ocorre a redução uma mudança no volume é definida como V/ $/ N_{0}$. Quando os corpos 1 (núcleo não reduzido) e 2 (casca reduzida) estão juntos o raio final da interface de equilíbrio (após a ligação) é r"i. Como visto na Figura 15(C) o corpo 1 expande e o corpo 2 encolhe para alcançar o equilíbio dentro do raio r"i e fora do raio $r$ ". Realizando a análise de tensão para 0 núcleo esférico e para a casca esférica. As condições de contorno foram aplicadas para obter os valores da tensão interfacial [112].

Uma vez que o núcleo está sob tensão e a casca está sob compressão, o sinal de menos é usado para indicar tensões compressivas. A soma do deslocamento do núcleo e da casca é igual para o deslocamento radial da casca externa, se estivesse isolada. Isto pode ser visto mais claramente na Figura $15(C)$, na qual pode ser visto que $r_{i}$ tem de expandir para $r^{\prime}{ }_{i}$, e $r_{i}^{\prime}$ têm de encolher para $r$ "i em ordem para manter a continuidade no contorno entre as porções reduzidas e não reduzidas [112]. 
a)

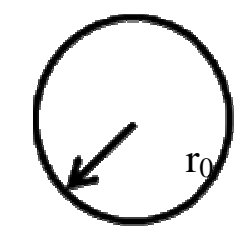

b)

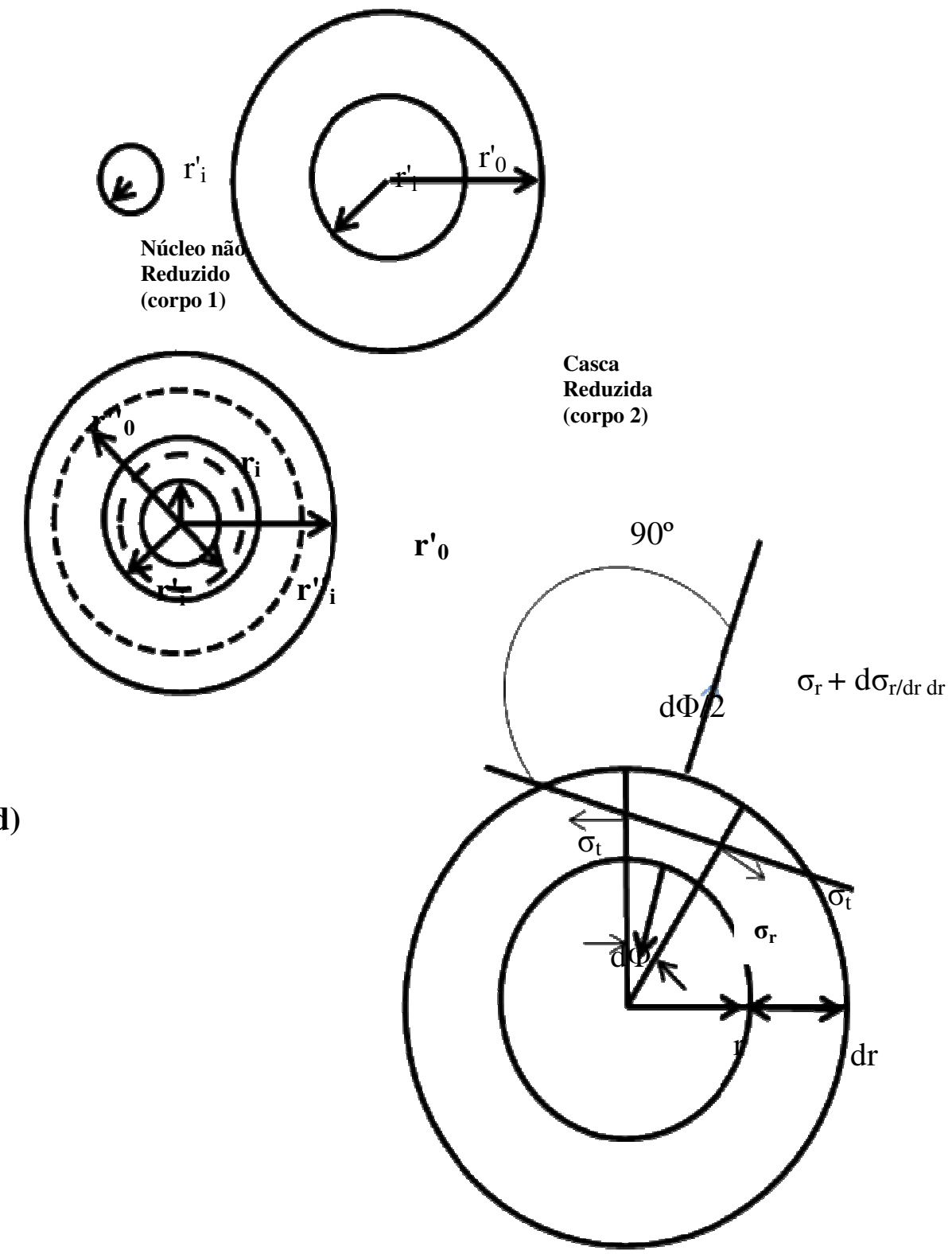

Figura 15: Análise das tensões devido as mudanças dimensionais da pelota. a) antes da redução, b) após a redução, c) após a ligação e d) elemento infinitesimal da casca externa [112].

Meyers e Tantevee [112], chegaram a duas expressões que descrevem as tensões geradas nas pelotas de minério de ferro devido à redução. As tensões geradas são radial e tangencial expressa pelas equações 14 e 15 respectivamente. 
$\sigma_{r}=\frac{E}{(1-2 v)}\left[\left(1+\frac{\Delta V}{V_{0}}\right)^{1 / 3}\right] \cdot\left[\frac{1}{1-\frac{1+v}{\left(C-B r^{m-n} D\right)}-\frac{1+v}{\left(\frac{-1}{B} r^{m-n} C+D\right)}}\right]$

Equação 3

Onde $C=(1-v) n+2 v$ e $D=(1-v) m+2 v$. A equação (14) expressa a tensão radial em termos do aumento de volume $\Delta V / V_{0}$, o coeficiente de Poisson's $(v)$, módulo de elasticidade $(E)$, e o raio inicial do pellet $\left(r_{0}\right)$. O termo B é o módulo volumétrico ou o inverso da compressibilidade $B=\sigma_{m} / \Delta=1 / \beta$, ele relaciona a pressão sobre o núcleo em todas as direções $\left(\sigma_{m}\right)$ com as mudanças de volume devido a variação de temperatura $(\Delta)$. A equação (15) expressa a tensão tangencial $\left(\sigma_{t}\right)$.

$\sigma_{t}=\frac{E}{(1-2 v)}\left[\left(1+\frac{\Delta V}{V_{0}}\right)^{1 / 3}-1\right] \cdot\left[\frac{1}{1-\frac{1+v}{\left(F-B^{\prime} G r^{m-n}\right)}-\frac{1+v}{\left(\frac{-1}{B} F r^{(m-n)}+G\right)}}\right]$ Equação 4

Onde $F=v n+1 ; G=v m+1 ; e B^{\prime}=[(v n+1)] /(v m+1) r_{0}^{(n-m)}$. O cálculo foi feito usando $\Delta V / V_{0}=0,10, r_{0}=0,555 \mathrm{~cm}$, e $E=3,14 \times 10^{4} M N / m^{2}$. A Figura 15a mostra a variação de $\sigma_{\mathrm{r}}$ e $\sigma_{\mathrm{t}}$ gerada na interface com raio de interface para a transformação hematita-magnetita.

Esta análise de tensões foi aplicada para a reação wustita-ferro, o que coloca o núcleo sob compressão e a casca esférica de ferro sob tração devido a diminuição do volume; a mudança no volume é em torno de 5\% [112]. As 
tensões radial e tangencial podem ser expressas pelas equações (14) e (15), fazendo $\Delta \mathrm{V} / \mathrm{V}_{0}=-0,05$

Quanto maior a porcentagem de redução, ou seja, um valor pequeno do raio da interface, maiores serão as tensões radiais e tangenciais geradas nas reações de transformação da hematita para magnetita e da wustita para ferro. Para a reação hematita-magnetita, a tensão radial é de tração e a tensão tangencial é de compressão. A transformação wustita-ferro envolve uma mudança de volume com sinal oposto a transformação hematita-magnetita. De tal forma que as tensões radiais e tangenciais são opostas às da transformação hematita-magnetita. Isto significa que a tensão radial é compressiva e a tensão tangencial é de tração. Minerais e cerâmicas exibem uma maior resistência à compressão do que à tração. Por isso a preocupação é para a tensão tangencial tanto para a transformação hematita-magnetita e para a transformação wustita-ferro. A tração radial tenderá a produzir a separação das interfaces e trincas ao longo da circunferência (trincas circunferênciais). A tração tangencial tenderá a produzir trincas normais a sua direção; estas trincas propagarão ao longo de um plano radial. Conforme Meyers e Tantevee [112] e apartir da análise de tensões conduzidas, a transformação hematita-magnetita tenderá a produzir trincas circunferênciais e a transformação wustita-ferro tenderá a produzir trincas radiais. A magnitude das tensões é suficitente para produzir a fratura. As tensões geradas pelas reações excedem o limite de resistência dos pellets [112].

Portanto o surgimento de trincas está associado as mudanças de volume associados a redução das pelotas, e também devido a temperatura, pois a diferentes fases que surgem possuem coeficientes de dilatação diferentes.

\subsubsection{Estágios na redução da hematita}

Olivier e Devisme [63] estudaram os diferentes estágios de processamento de pó de hematita de ferro sintéticos usando uma termobalança e outras técnicas analíticas, tais como Difração de raios- $X, M E V$ e 
espectroscopia Mössbauer. A maioria dos experimentos foram realizados a $800^{\circ} \mathrm{C}$ sob hidrogênio diluído com hélio. Segundo Devisme [63] primeiramente ocorre uma transformação de fase rápida de hematita para magnetita, o que não apresenta uma evolução morfológica significativa e sem mudança no tamanho da partícula. Uma vez que toda hematita transformou-se, começa redução da magnetita para wustita. Esta reação é lenta, uma vez que traços de magnetita podem ser observados quase até o fim. Parece que esta reação evolui a partir da superfície para dentro dos grãos. Enquanto a magnetita é reduzida à wustita, outra reação ocorre até o aparecimento do ferro. A análise de difração de raios- $X$, mostra uma mudança na estrutura do cristal de wustita, uma conseqüência de sua redução da composição $\mathrm{Fe}_{0,89} \mathrm{O}$, para $\mathrm{Fe}_{0,95} \mathrm{O}$. As duas reações (magnetita para wustita e wustita para wustita) são provavelmente simultâneas. A formação da wustita é acompanhada por mudança na morfologia das partículas, grãos menores próximos uns dos outros podem se juntar para dar forma um anel de partículas. A presença de magnetita até o fim da redução global mostra que o fim da redução de magnetita é lento, provavelmente porque a wustita que se formou na superfície de grãos é densa e introduziu uma resistência à difusão cada vez mais elevada. Em seguida, as primeiras sementes de ferro aparecem e crescem, na parte externa dos grãos de ambas as estruturas alongadas e maciças. Este rápido crescimento faz com que as novas estruturas formadas tendem a se juntar e formar pontes. A diminuição do volume molar associado à esta reação é importante, cerca de $43 \%$. Além dos grãos de ferro serem densos, a diminuição do volume resulta em uma menor porosidade intergranular. Finalmente, o autor [63] apresenta um diagrama simplificado ilustrando as etapas de processamento. A Figura 16 mostra as diferentes fases e a evolução morfológica das partículas durante a redução a $800{ }^{\circ} \mathrm{C}$ com hidrogênio e hélio. 


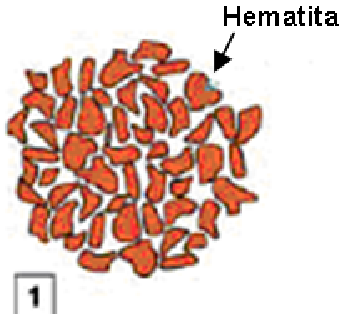

Hematita inicial consistindo de vários grãos
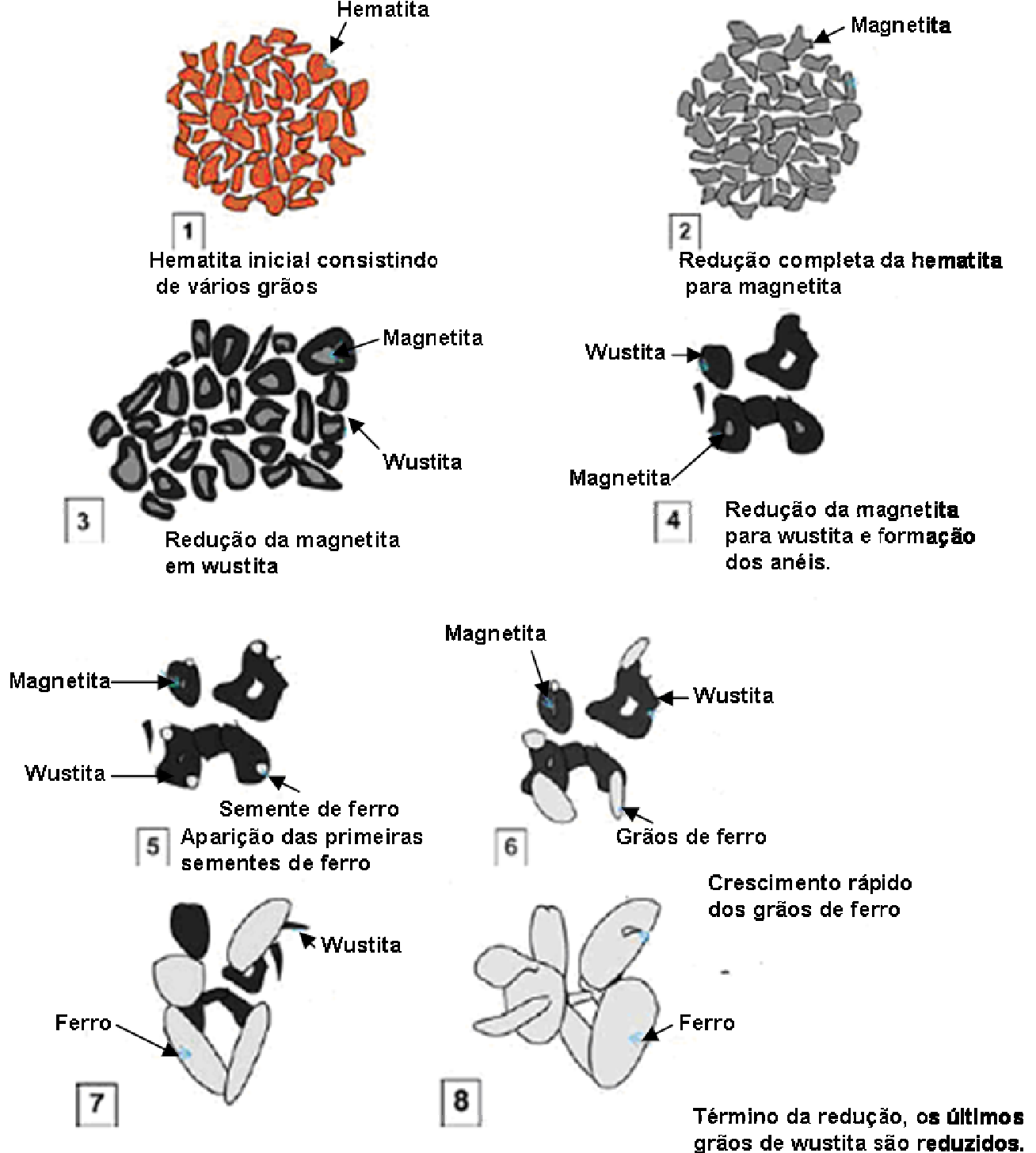

Particulas continuam a crescer

Figura 16: As diferentes fases e a evolução morfológica das partículas durante a redução a $800{ }^{\circ} \mathrm{C}, 10 \% \mathrm{H}_{2}$ em He [63].

\subsubsection{Mecanismos para a redução da wustita}

Uma vez que esta reação é a mais lenta, ela é o que controla a redução final [77]. A formação de diferentes morfologias de ferro em nódulos de wustita [77] ou ferro na superfície causando ligação entre as partículas e pode causar dificuldades industriais $[77,79]$. 


\section{Mecanismo geral para a redução da wustita}

A redução de óxidos não estequiométricos foi estudada por Wagner [78] em 1952 e um mecanismo de reação foi proposto. Suas etapas são:

- Reação química na superfície:

$$
\mathrm{H}_{2}+\mathrm{O}^{2-}+2 \mathrm{Fe}^{3+} \rightarrow \mathrm{H}_{2} \mathrm{O}+2 \mathrm{Fe}^{2+} \text { Equação } 5
$$

Envolve a quimissorção da molécula de hidrogênio na superfície da wustita, a transferência de um íon $\mathrm{O}^{2-}$ para a fase gasosa, a conversão de dois íons $\mathrm{Fe}^{3+}$ e $\mathrm{Fe}^{2+} \mathrm{e}$ o desaparecimento da lacuna na superfície. Esta migração é realizada através de trocas sucessivas entre a lacuna e o cátion localizado na camada superior [78].

A relação $\mathrm{Fe} / \mathrm{O}$ da wustita aumenta na superfície, onde há a formação de um gradiente de concentração, fazendo com que o ferro se difunda para 0 interior e lacunas para o exterior. O fenômeno é ilustrado na Figura 17 [78].

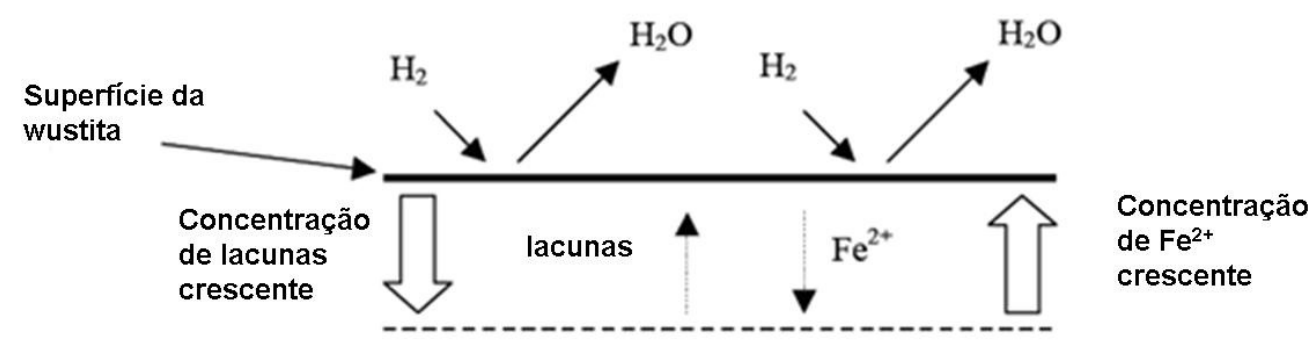

Figura 17: Diagrama do mecanismo de Wagner [78].

A atividade do ferro aumenta até a superfície à medida que ocorre o progresso da reação e provoca a formação de uma região saturada abaixo da superfície [78].

A atividade do ferro metálico no núcleo é menor que a do íon de ferro, assim existe a difusão da superfície para o núcleo supersaturado, causando o crescimento. Enquanto isso, a reação de redução continua [78]. 


\section{Diferentes morfologias}

São detalhados os mecanismos da criação das diferentes morfologias de ferro. De acordo com as condições experimentais (temperatura, teor de água no gás de redução), a camada de ferro produzido pode ser porosa [57, 62, 79, 80, 81] ou densa [59, 79, 80]. Estruturas especiais, chamados whiskers, também podem aparecer [59, 82, 83, 84].

O estudo mais abrangente sobre a presença ou ausência de poros na camada de ferro produzido na superfície da wustita foi conduzido por St John et al. em uma série de publicações [79, 80, 85]. Os autores estão particularmente interessados em influências da temperatura, do teor de água na mistura do gás, e da quantidade de falhas na estrutura cristalina da wustita. Os experimentos foram realizados com partículas de wustita densa de 0,3 mm de diâmetro, a temperatura utilizada variou entre 600 e $1100{ }^{\circ} \mathrm{C}$ e os conteúdos volumétricos de água foram de $0,10,20$ e $30 \%$. St John et al. [79, 80] observaram e classificaram as microestruturas obtidas em três tipos: A, B e C. O tipo A (Figura 18a) corresponde à formação de ferro poroso após a redução completa da amostra. Sua aparência é uma espécie de dendritas que penetram no interior da wustita ainda não reduzida. A tipo B (Figura 18.b) é caracterizado pela presença de ferro poroso na wustita densa. $O$ tamanho dos poros é maior que no caso anterior, mas eles também são menos numerosos. Parece que a formação desses poros está relacionada com o teor de água no gás [79].

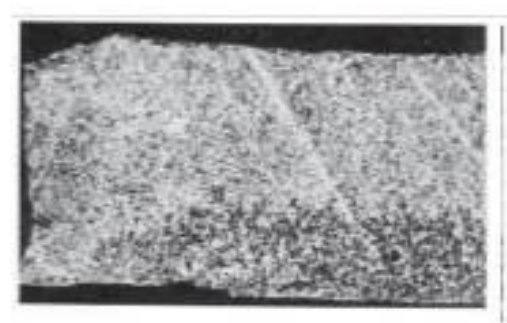

(a)

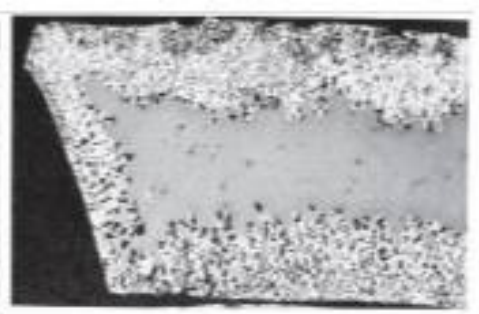

(b)

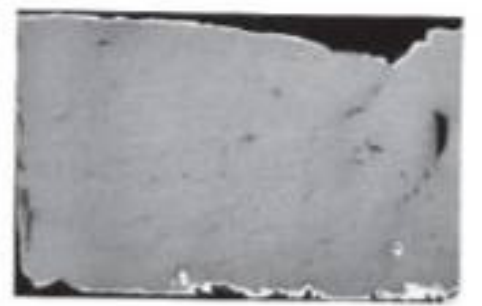

(c)

Figura 18: Seções metalográficas da wustita reduzida a $900{ }^{\circ} \mathrm{C}$. $(A): y=0,1,100 \% \mathrm{H}_{2}$, 4min. (B): $y=0,1,90 \% \mathrm{H}_{2}+10 \% \mathrm{H}_{2} \mathrm{O}, 30 \min$. (C): $\mathrm{y}=0,05,70 \% \mathrm{H}_{2}+30 \% \mathrm{H}_{2} \mathrm{O}, 420$ $\min [79]$. 
O tipo $C$ não tem poros na superfície. Nota-se a presença de apenas uma camada fina de ferro denso na wustita densa (Figura 18.c). Observações dos primeiros momentos da redução feitas por MEV mostram que em todos os casos de germinação e crescimento, o ferro está na forma de uma camada densa e que somente mais tarde a porosidade necessária para obter uma estrutura do tipo A aparece [79].

Alguns autores [59, 80, 59] observaram uma morfologia particular que ocorre na camada de ferro, é a formação de nódulos de ferro em forma de saliências alongadas, chamados de "whiskers" que crescem para fora. Um problema para os fabricantes que desejam implementar a redução de minério de ferro por hidrogênio é a adesão das partículas. Os whiskers são considerados como a causa do fenômeno de ligação das partículas. A Figura 19 apresenta algumas fotos [83]. El Mujahid et al. [21] observaram que entre 580 e $900{ }^{\circ} \mathrm{C}$ e com conteúdo de água baixo, os whiskers são o principal modo de germinação ferro a partir da wustita densa. Sua forma ainda pode variar de agulha fina ou cônica.
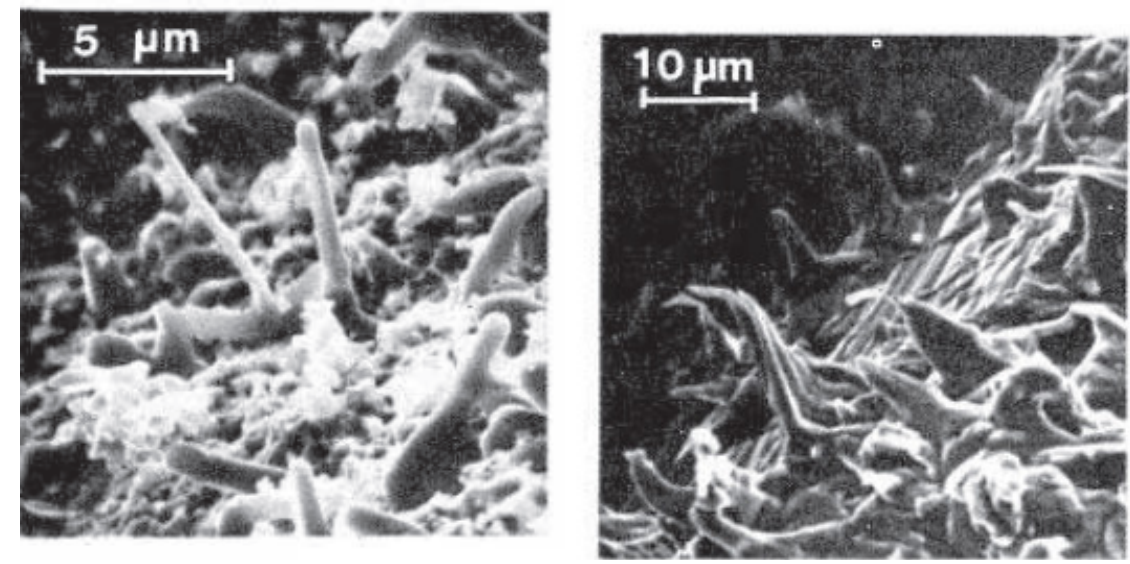

Figura 19: Fotografias de whiskers na superfície da camada de ferro [83].

\section{Formação de várias morfologias}

Após a classificação de diferentes morfologias, St John et al. [79, 80, 85] têm tentado explicar os mecanismos que levam à sua formação. Inicialmente, 0 contato da wustita com um gás leva à reação de redução parcial de wustita:

$$
\left(1-y_{2}\right) F e_{1-y 1} O+\left(y_{1}-y_{2}\right) H_{2(g)} \rightarrow\left(1-y_{1}\right) F e_{1-y 2} O+\left(y_{1}-y_{2}\right) H_{2} O_{(g)} \quad \text { Equação } 6
$$


Isto é o equivalente para o início do mecanismo de Wagner [78]. Há um consumo de oxigênio e um aumento na concentração de $\mathrm{Fe}^{2+}$ na superfície do óxido. Este primeiro passo leva ao aparecimento de um gradiente entre a superfície e o centro da wustita e distribuição de íons ferrosos. A composição da wustita na interface com o gás é uma função da difusão e da reação química. O gradiente de concentração é normal à superfície da wustita no caso de uma superfície plana, o ferro é liberado na mesma direção. No entanto, se há um defeito na superfície, a difusão do ferro ocorre também em direções laterais. Isto é a concentração de íons de ferro na wustita é mais baixa na parte inferior do defeito, assim o equilíbrio com o gás, resulta em uma reação. A wustita é reduzida progressivamente, causando a corrosão e formação de poros na superfície quase plana. Este mecanismo é ilustrado na Figura 20 (para o caso análogo de uma reação de $\mathrm{CO}$ ) linhas pretas representam isoconcentração de íons ferroso [79] .

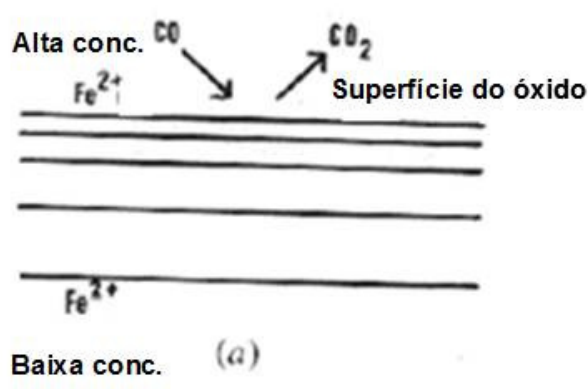

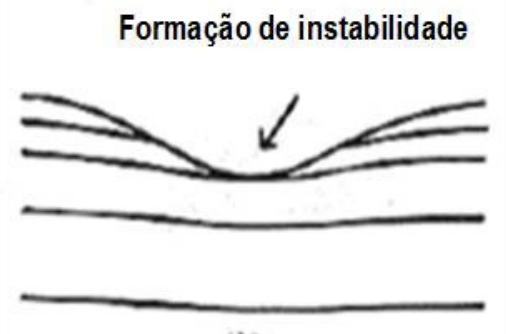

(b)

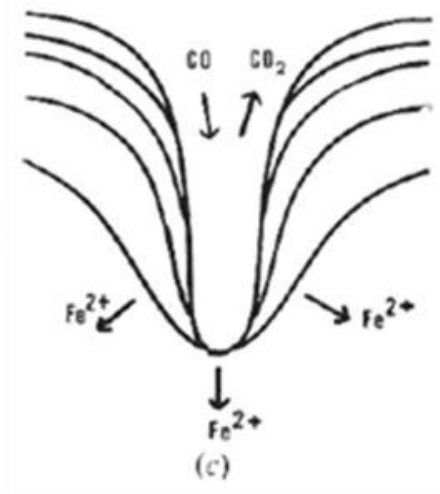

(c)

Figura 20: Representação esquemática de um crescimento de poros em um defeito de superfície [80].

A fim de verificar a influência da relação entre a velocidade da reação química e a difusão na morfologia formada, os autores [79] realizaram as mesmas experiências com uma mistura $\mathrm{CO} / \mathrm{CO}_{2}$ dando uma taxa de reação química 10 vezes mais baixa. A $900{ }^{\circ} \mathrm{C}$, com $\mathrm{y}=0,1$ e com o mesmo potencial de oxigênio em ambos os casos, uma morfologia Tipo B é obtida quando se 
usa o hidrogênio, enquanto que com $\mathrm{CO}$, uma morfologia do Tipo $\mathrm{C}$ é formada. Isto está de acordo com o mecanismo citado anteriormente. Após a reação ser realizada de acordo com os autores [79], elas estão de acordo com o mecanismo Wagner [78]. Isto é, o progresso da redução da wustita em contato com o gás obteve-se uma região mais concentrada em íons de ferro e, finalmente, obteve-se uma região supersaturada. A wustita metaestável é então dividida em ferro metálico e wustita. Após a germinação, o excesso de íons ferrosos na região supersaturada em torno do embrião cria um importante fluxo de íons de ferro através do volume e na superfície, como mostrado esquematicamente na Figura 21 (com CO como gás de redução) [79].

As difusões na superfície e no volume exercem influência sobre a forma do germe. De fato, a supersaturação da região próxima à semente faz com que apareça uma densidade de fluxo de difusão em direção à semente. Esse fluxo é importante no começo, mas diminui com o consumo de íons ferrosos. Momentos após a germinação, a difusão de superfície se torna a mais importante, porque o excesso é mantido pela reação química que consome oxigênio na superfície. Após germinação, a principal fonte é a difusão através do volume, a semente vai crescer por incorporação de ferro metálico a partir de baixo. A semente tem a forma de uma agulha (ou whiskers). Então, a densidade de fluxo de difusão diminui, a difusão na superfície torna-se dominante e, em seguida, o ferro é incorporado nas laterais do germe causando um aumento de sua base. O resultado final é um cone de sementes rodeado por uma camada densa de ferro que cobre a wustita [79]. 


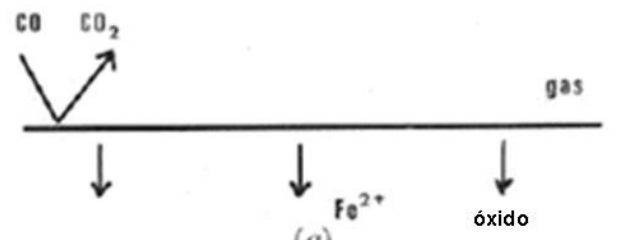

(a)

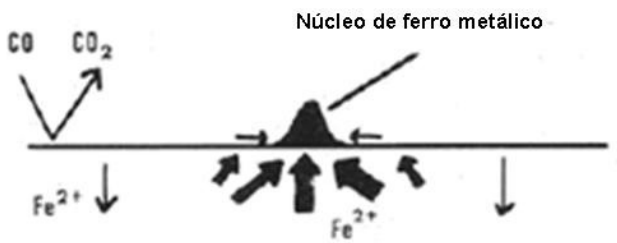

(b)

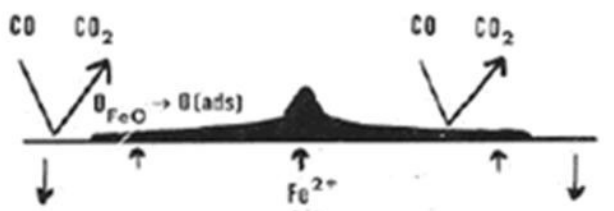

(c)

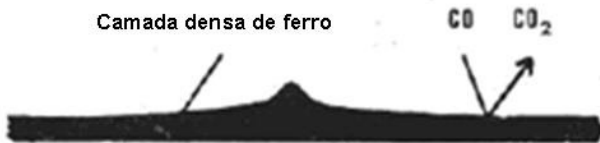

Figura 21: Representação esquemática da nucleação de ferro e etapa de crescimento [79].

O fluxo de difusão através do volume da wustita pode ser afetado pela presença de contornos de grão ou defeitos que fornecem caminhos preferenciais para a difusão do ferro. Uma explicação é a de St John et al [80], após a formação da camada densa, quando a atmosfera é suficientemente redutora, parece que o ferro sofre uma reação de solubilização, levando à formação de irregularidades na forma de vulcões como mostrado na Figura 20. A imagem da Figura 22b mostra que o buraco no meio leva diretamente à rede de poros que se desenvolve a seguir, mostrando que o aparecimento desses "Vulcões" está relacionado com os poros [85]. A Figura 22 [85] mostra fotomicrografias de MEV da superfície da camada de ferro depois da decomposição 

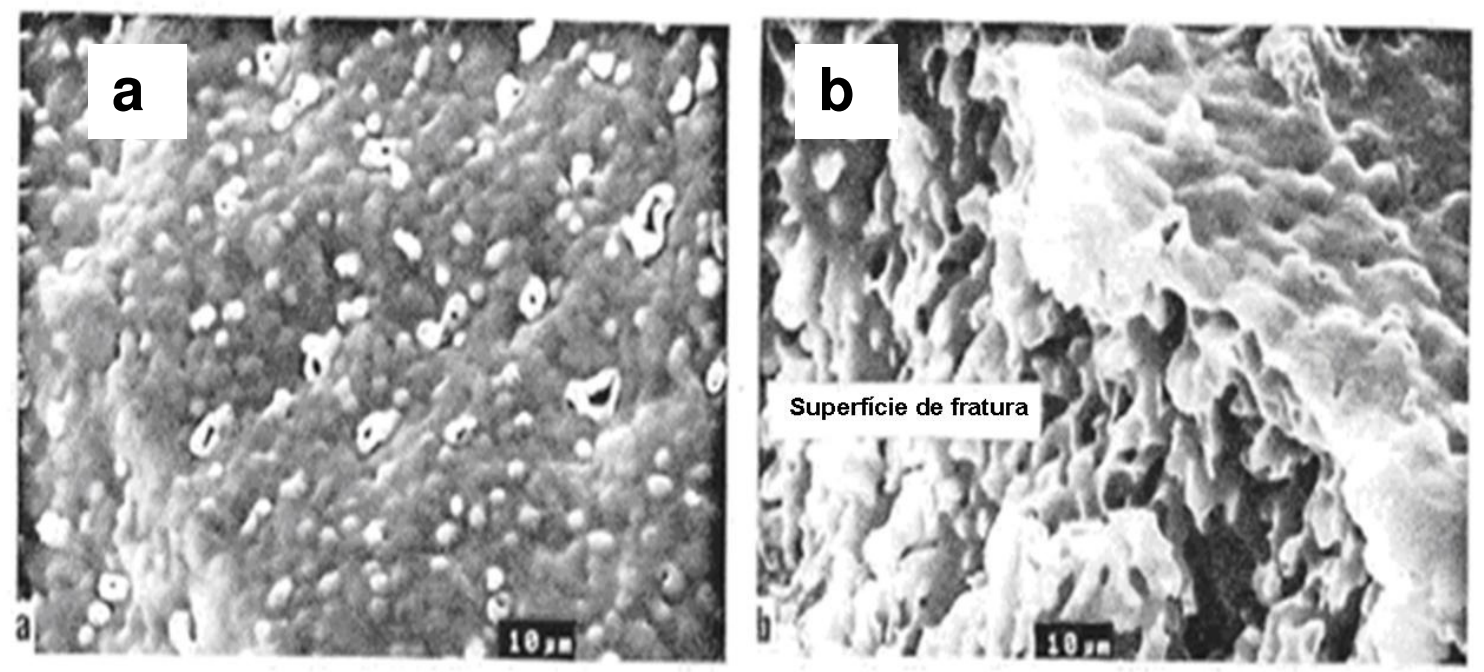

Figura 22: Fotomicrografias de MEV da superfície da camada de ferro depois da decomposição [85].

Estes resultados sobre a formação da estrutura do tipo A de acordo com St John et al. [79, 80, 85] não estão de acordo com observações de outros autores.

\subsection{Métodos de estudos de cinética por termogravimetria}

A estabilidade térmica de uma reação pode ser avaliada através de parâmetros cinéticos, como energia de ativação, a ordem de reação e a velocidade, podendo ser rápida ou lenta dependendo das condições em que tal reação ocorre [41].

A cinética química é o estudo das velocidades de reação e dos mecanismos de reação. A velocidade de uma reação química pode depender de variáveis como pressão, temperatura, presença de catalisadores e, em muitos casos, é possível conseguir melhores velocidades com a escolha apropriada das condições [41].

O modelo chamado de teoria das colisões é utilizado para explicar os fatos experimentais observados em relação à velocidade das reações químicas [41].

Os principais postulados deste modelo são: 
- Para que uma reação ocorra é necessário que haja colisão entre as partículas reagentes. Durante esta colisão as ligações dos reagentes são desfeitas, ocorre rearranjo dos átomos, o que leva a formação de outras espécies, ou seja, os produtos [41];

- Nem todas as colisões resultam em reação. As colisões que resultam em reações, chamadas colisões efetivas, devem envolver determinada quantidade de energia e ocorrer segundo uma orientação apropriada;

- A velocidade de reação é proporcional ao número de colisões efetivas por segundo entre as partículas reagentes.

A energia mínima necessária para que ocorram colisões efetivas é chamada energia de ativação [41].

A termogravimetria é uma técnica utilizada na determinação de parâmetros cinéticos [41].

Normalmente, são utilizados três métodos para a determinação dos parâmetros cinéticos: [41]

- Termogravimetria isotérmica, na qual a perda de massa é analisada em função do tempo a uma temperatura constante.

- Termogravimetria dinâmica, na qual a amostra é submetida a uma rampa de aquecimento em diferentes taxas.

- Termogravimetria semi-isotérmica, na qual a amostra é aquecida em uma série de temperaturas diferentes. 


\section{Materiais e métodos}

Nesta seção são apresentados os materiais, métodos e equipamentos utilizados neste trabalho.

Foram utilizados três tipos distintos de pellets feed além de pelotas para a redução direta. As matérias primas foram caracterizadas e foram realizados ensaios de redução em diferentes temperaturas e com diferentes atmosferas.

A Figura 23 mostra o fluxograma das atividades desenvolvidas neste trabalho, estas atividades serão descritas detalhadamente nesta seção.

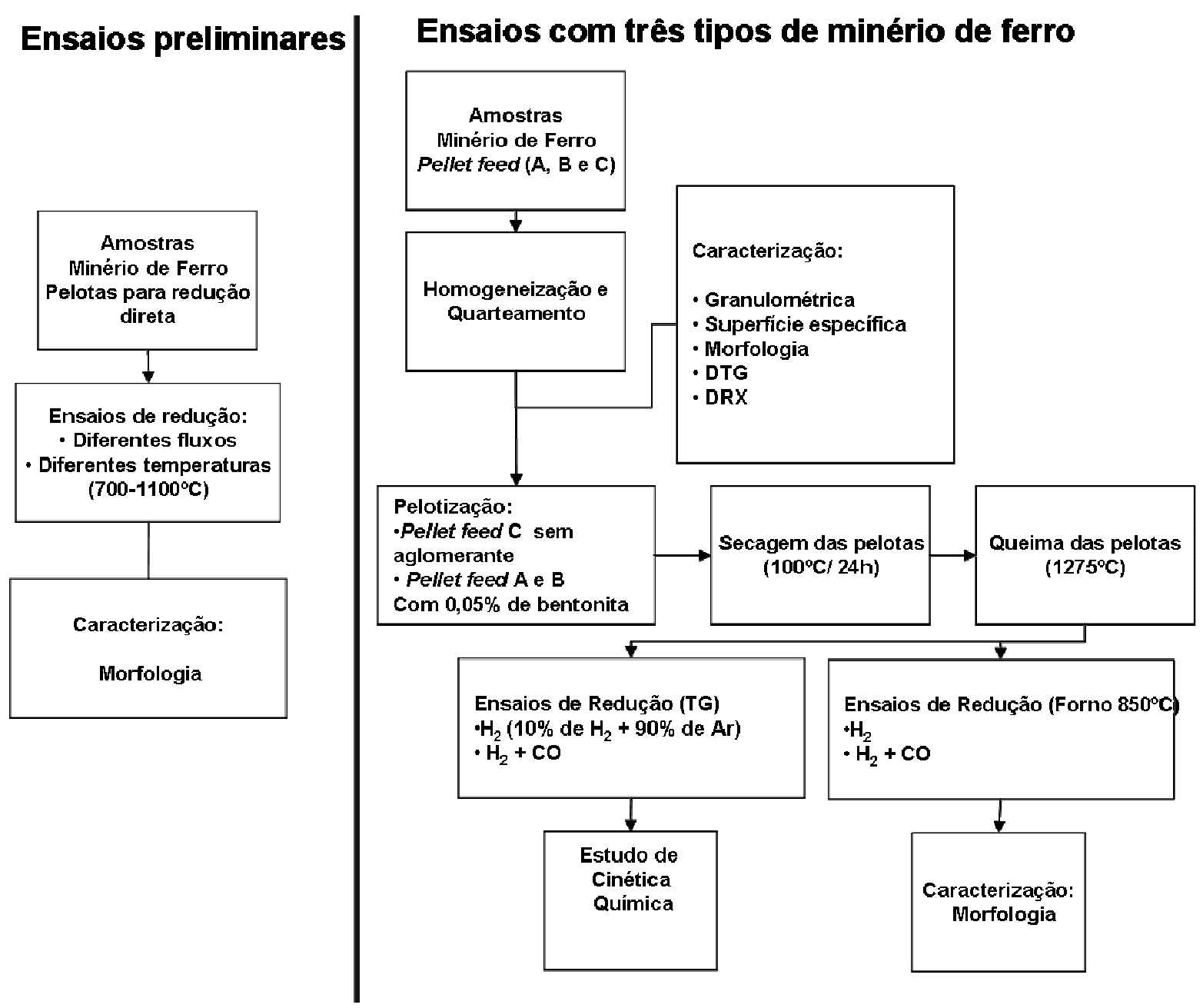

Figura 23: Fluxograma das atividades desenvolvidas.

Os pellets feed foram caracterizados por difração de raios-X $\mathrm{e}$ quantificação das fases pelo método de Rietiveld, distribuição de tamanho de partículas por difração a laser, área de superfície específica por adsorção de 
nitrogênio, densidade aparente em um picnômetro, análise microestrutural por imagens de Microscopia Eletrônica de Varredura.

Inicialmente, a fim de estabelecer as condições experimentais, foram realizados experimentos preliminares exploratórios com as pelotas comerciais para a redução direta, a fim de se conhecer e estabelecer condições experimentais, tais como fluxo de gás redutor e temperaturas. Foram realizados ensaios de redução em atmosfera de 10\% de hidrogênio e $90 \%$ de argônio. Estes ensaios foram em isotermas de $700{ }^{\circ} \mathrm{C}, 800{ }^{\circ} \mathrm{C}, 900^{\circ} \mathrm{C}$, $1000^{\circ} \mathrm{C}$ e $1100^{\circ} \mathrm{C}$ por um tempo de uma hora e em cada temperatura 0 fluxo de gás foi de $50 \mathrm{~mL} / \mathrm{min}, 100 \mathrm{~mL} / \mathrm{min}, 150 \mathrm{~mL} / \mathrm{min}$ e $200 \mathrm{~mL} / \mathrm{min}$. As pelotas reduzidas nestas condições foram caracterizadas por imagens em uma lupa.

Depois de realizada a primeira etapa (ensaios preliminares) com as pelotas para redução direta e estabelecidas condições experimentais, foi realizada a caracterização e pelotização dos três tipos de pellets feed. As pelotas foram selecionadas, secadas e queimadas. Com as pelotas produzidas a partir dos pellets feed $A, B$ e $C$ foram realizados ensaios de redução em termobalança e em forno tubular. Os ensaios de redução na termobalança foram realizados em atmosferas redutoras e temperatura variando de $500{ }^{\circ} \mathrm{C}$ até $1100{ }^{\circ} \mathrm{C}$ com patamares de 15 minutos a cada $50{ }^{\circ} \mathrm{C}$. As curvas de perda de massa foram analisadas e investigadas na análise cinética pelo método FSIA. Os resultados dos três tipos de pellets feed foram comparados.

\subsection{Materiais}

Para a realização deste trabalho foram utilizados minérios de ferro. Sendo três tipos de pellets feed, identificados com os nomes A, B e C. Foram utilizadas também pelotas comerciais para redução direta. Os gases utilizados foram mistura de hidrogênio e argônio, monóxido de carbono e nitrogênio. 


\subsubsection{Pellets feed e pelotas para redução direta}

Dentre os tipos de minérios disponíveis no mercado, estão as pelotas para alto-forno e pelotas para os processos de redução direta. Optou-se por utilizar pelotas para processos de redução direta com o intuito de estabelecer as condições experimentais para posterior redução das pelotas obtidas a partir dos pellets feed A, B e C. As pelotas para redução direta foram fornecidas pela mesma empresa mineradora que forneceu o pellet feed $\mathrm{C}$.

Optou-se por trabalhar com três tipos de pellets feed afim de se realizar um estudo comparativo entre eles. Investigando possíveis diferenças entre os três pellets feed. As possíveis diferenças entre os pellets feed A, B e C, pode-se ou não se relacionar com os eventos que estão envolvidos no processo de redução. Os pellets feed A e B foram fornecidos por uma empresa mineradora e o pellet feed $\mathrm{C}$ foi fornecido por outra empresa mineradora.

\subsubsection{Características dos pellets feed e pelotas para redução direta}

A Tabela 4 mostra a composição química dos pellets feed A, B e C e das pelotas para redução direta. Estas características dos materiais foram fornecidas pelas empresas que cederam os respectivos materiais.

Nota-se da Tabela 4 que a composição química dos pellets feed são semelhantes. A quantidade de ferro total (FeT) presente em todas as amostras são próximas. A perda por calcinação (P.P.C.) dos pellets feed A, B e C são próximas, enquanto que as pelotas para redução direta não exibem perda por calcinação. Os mesmos elementos aparecem nos três tipos de pellets feed e em proporções bem próximas. A maior diferença é a quantidade de $\mathrm{SiO}_{2}$. Comparando os pellets feed A, B e C nota-se que o pellet feed A quando comparado aos pellets feed $\mathrm{B}$ e $\mathrm{C}$ apresenta maior quantidade de $\mathrm{SiO}_{2}$. 
Tabela 4: Composição química dos pellets feed A, B e C e das pelotas para redução direta.

\begin{tabular}{|c|c|c|c|c|}
\hline $\begin{array}{c}\text { Elementos } \\
\text { e }\end{array}$ & $\begin{array}{c}\text { Pellet feed A } \\
\text { (\% em massa) }\end{array}$ & $\begin{array}{c}\text { Pellet feed B } \\
\text { (\% em massa) }\end{array}$ & $\begin{array}{c}\text { Pellet feed C } \\
\text { (\% em massa) }\end{array}$ & $\begin{array}{c}\text { Pelota para } \\
\text { Redução } \\
\text { direta } \\
\text { (\% em massa) }\end{array}$ \\
\hline FeT $^{*}$ & 66,9 & 67,2 & 67,11 & 67,8 \\
\hline $\mathbf{F e O}$ & 1 & 0,9 & 1,10 & -- \\
\hline $\mathbf{S i O}_{2}$ & 1,3 & 1,03 & 1,03 & 1,37 \\
\hline $\mathbf{A l}_{2} \mathbf{O}_{3}$ & 0.4 & 0,4 & 0,38 & 0,43 \\
\hline $\mathbf{C a O}^{\mathbf{M g O}}$ & 0,1 & 0,1 & 0,08 & 0,86 \\
\hline P.P.C. & 0,03 & 0,03 & 0,03 & -- \\
\hline $\mathbf{P}$ & 2,41 & 2,29 & 2,43 & -- \\
\hline
\end{tabular}

${ }^{*}$ FeT - ferro total

${ }^{* *}$ P.P.C - perda por calcinação

\subsubsection{Gases}

Os gases usados neste trabalho foram:

- Mistura contendo $90 \%$ de argônio e 10\% de hidrogênio

- Monóxido de carbono 99,99\%

- Nitrogênio 99,99\%

\subsection{Métodos}

Nesta seção são apresentadas as técnicas e equipamentos utilizados na: caracterização dos pellets feed, caracterização das pelotas parcialmente e totalmente reduzidas. 


\subsubsection{Homogeneização e quarteamento dos Pellets feed}

Os pellets feed A, B e C foram homogeneizados, quarteados $\mathrm{e}$ pelotizados. As pelotas obtidas a partir dos pellets feed A, B e $\mathrm{C}$ foram classificadas, secas e queimadas.

Três lotes diferentes de $40 \mathrm{~kg}$ de pellet feed foram homogeneizados e quarteados separadamente em pilha alongada e cônica. Foram quarteadas amostras para serem realizadas as análises de difração de raios- $X$, microscopia eletrônica de varredura, distribuição granulométrica, densidade aparente e adsorção de nitrogênio. A Figura 24 mostra a homogeneização e quarteamento em pilha alongada e em pilha cônica.

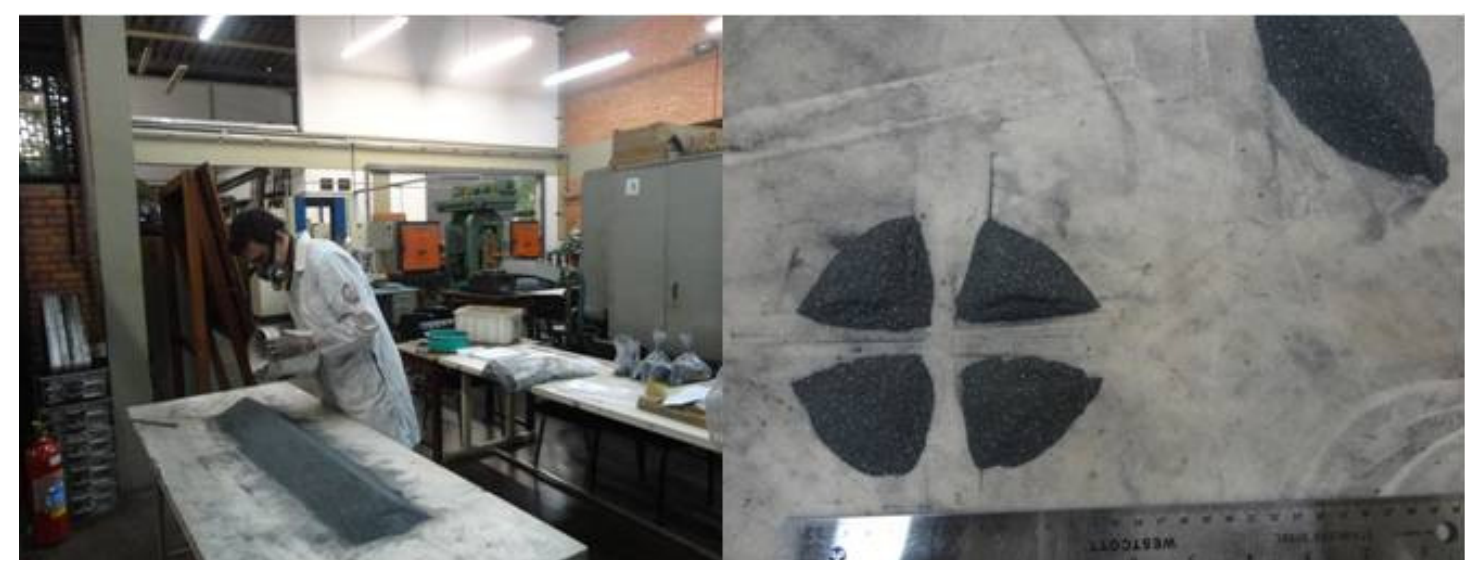

Figura 24: Homogeneização e quarteamento dos pellets feed.

\subsubsection{Difratometria de raios- $X$}

A difratometria de raios- $X$ foi empregada com o objetivo de verificar as fases mineralógicas presentes nos pellets feed $A, B$ e $C$ e nas pelotas de redução direta antes da redução. Juntamente com o Método Rietveld, foi realizada a quantificação das fases dos pellets feed A, B e C e das pelotas de redução direta antes da redução.

A preparação das amostras foi iniciada com a pulverização destas em um almofariz. Em seguida, as amostras em pó, com granulometria inferior a $45 \mu \mathrm{m}$, foram compactadas em um porta amostras. O equipamento utilizado foi um difratômetro Siemens, modelo $D 500$, com radiação cobre $K \alpha(\lambda=1,5418 \AA$ ), 
potência de $40 \mathrm{kV}$ e $40 \mathrm{~mA}$. As condições de análise foram: passo de $2^{\circ}$, tempo de passo de 1 s e intervalo de medida, em $2 \theta$, de $10^{\circ}$ a $90^{\circ}$. As amostras foram submetidas a um feixe de raios monocromático. Durante este procedimento, cada partícula do pó se comporta como um cristal, com orientação aleatória em relação ao feixe de raios incidentes.

\subsubsection{Método Rietveld}

É um metodo de refinamento de estruturas cristalinas, fazendo uso de dados de difração de raios-X ou neutrons, por pó. A estrutura cristalina é refinada, de forma a fazer com que o difratograma calculado com base na estrutura cristalina, se aproxime o melhor possível do difratograma observado $[86,87]$. O difratograma observado deve ser obtido num processo de varredura passo-a-passo com incremento $\Delta 2 \theta$ constante $[88,89]$. Foi utilizado o software gratuito GSAS/EXPGUI para realizar o refinamento das estruturas cristalinas e quantificar as fases presentes nos pellets feed A, B e C e nas pelotas de redução direta antes da redução.

\subsubsection{Distribuição de tamanho de partículas}

Foi realizada a caracterização de distribuição de tamanho de partículas por difração a laser. Foi utilizado o equipamento Malvern modelo Mastersizer 2000. O ensaio foi realizado utilizando água como meio dispersivo e ultrasom por 5 minutos. Os ensaios foram realizados afim de se conhecer como era a distribuição de partículas dos pellets feed, e se havia diferença na distribuição de tamanhos das partículas entre os pellets feeds A, B e C.

\subsection{5 Área de superfície específica}

A área de superfície específica de um material pode depender da distribuição de tamanho de partículas, da forma das partículas e da porosidade. 
A superfície específica foi determinada pelo método B.E.T. (Brunauer, Emmett e Teller).

As medidas foram realizadas num equipamento da Micrometitics modelo ASAP 2020 que utiliza técnica de adsorção física por volume estático com isotermas de adsorção e desorção. O tratamento térmico anterior a análise foi realizado a $300^{\circ} \mathrm{C}$ sob vácuo.

\subsubsection{Densidade das partículas dos pellets feed}

As densidades aparentes dos pellets feed A, B e C foram determinadas utilizando-se um picnômetro. Para isso, determinou-se a massa do picnômetro vazio, após secá-lo. Foi adicionada a amostra com a massa medida em uma balança analítica. O picnômetro foi preenchido com água destilada e tampado. Pesou-se novamente o picnômetro contendo (amostra + água destilada) e as medidas anotadas [90, 91].

\subsubsection{Densidade real das pelotas}

A densidade das pelotas após serem queimadas foi determinada medindo-se a massa $(m) 10$ pelotas de cada tipo de pellet feed em uma balança analítica e medindo-se três vezes o diâmetro de cada pelota respectivamente. A partir destes dados foi calculado o volume ( $V$ ) de cada uma das pelotas. Utilizando a equação para densidade $\rho=\mathrm{m} / \mathrm{V}$, foi determinada a densidade média das pelotas $\left(\rho_{P}\right)$ dos pellets feed A, B e C. Conhecendo-se as densidades dos pellets feed $\left(\rho_{P F}\right)$ e a densidade das pelotas $\left(\rho_{P}\right)$, foi calculada a porosidade total $\left(\mathrm{V}_{\mathrm{p}}\right)$ das pelotas pela equação: $V_{P}=\left(1-\rho_{P} / \rho_{P F}\right) \times 100$ 


\subsubsection{Análises macro e microestrutural}

Foi realizada a caracterização da morfologia dos pellets feed A, B e C, da morfologia da seção das pelotas parcialmente e totalmente reduzidas e da superfície das pelotas totalmente reduzidas.

O equipamento utilizado para as análises foi o Microscópio Eletrônico de Varredura da marca Philips, modelo XL-30, equipado com uma microssonda eletrônica para análise espectrométrica de raios- $\mathrm{X}$.

As amostras de pellets feed A, B e $\mathrm{C}$ e as pelotas parcialmente reduzidas analisadas não são condutores elétricos, por tal motivo, foi utilizado 0 aparelho Sputter Coater da Balzers, modelo SCD 050, para o recobrimento com ouro das amostras.

Para a caracterização macroestrutural e morfológica dos pellets feed A, $B$ e $C$ foi realizada a separação granulométrica por peneiramento a seco conforme a norma ASTM B214-46T [92] com a finalidade de se verificar as morfologias em diferentes faixas granulométricas. As frações analisadas no MEV foram: (A) pellet feed, (B) fração retida na peneira com abertura de $0,149 \mathrm{~mm},(\mathrm{C})$ passante pela peneira com abertura de $0,149 \mathrm{~mm}$ e retida na peneira abertura de $0,088 \mathrm{~mm}$, (D) passante pela peneira com abertura de $0,088 \mathrm{~mm}$ e retida na peneira com abertura de $0,074 \mathrm{~mm}$, (E) passante pela peneira com abertura de $0,074 \mathrm{~mm}$ e retida na peneira com abertura de $0,053 \mathrm{~mm}$, (F) passante pela peneira com abertura $0,0523 \mathrm{~mm}$ e retida na peneira com abertura de $0,044 \mathrm{~mm}$ e $(G)$ fração que passou pela peneira de $0,044 \mathrm{~mm}$.

Para a observação das seções das amostras parcialmente reduzidas, foram escolhidas as pelotas com grau de redução de aproximadamente $25 \%$, $50 \%$ e $75 \%$. Estas pelotas foram reduzidas em ensaios realizados no forno tubular. Foi encontrada certa dificuldade na preparação das pelotas, pois as pelotas parcialmente reduzidas possuem em sua composição vários óxidos com diferentes durezas. Durante o lixamento das amostras, estas quebravam em pedaços menores. Para contornar este problema, as pelotas foram embutidas a frio com resina epóxi transparente. No embutimento a frio, a pelota 
era colocada em um molde de silicone lubrificado com graxa de silicone e então a resina já misturada com o catalisador foi despejada sobre a amostra preenchendo o molde e os espaços vazios. Após 24 horas e a resina estar curada e seca, as amostras foram lixadas até que se atingisse a seção central da pelota.

A preparação iniciava-se a fim de obter seções com boa qualidade para o ensaio macro e micrográfico. Foi realizado o lixamento a úmido em uma politriz utilizando-se sucessivamente lixas com granulometria de 220, 320, 400, 600.

Para a análise da superfície das pelotas totalmente reduzidas, as pelotas foram fixadas no porta amostra do MEV com fita adesiva condutora dupla face.

\subsection{Ensaios preliminares}

Para a realização dos ensaios preliminares foram utilizadas pelotas para redução direta. O lote de pelotas para a redução direta consistia de pelotas com vários tamanhos e massas. Foi realizada a separação das pelotas por meio de peneiramento. Foram selecionadas pelotas passantes pela peneira com abertura de $12 \mathrm{~mm}$ e retidas na peneira com abertura de 9,52 mm. Essa separação foi realizada com o intuito de se obter um lote de pelotas com massas bem próximas e que não excedessem o limite de carga da termobalança. A termobalança possui um limite máximo de massa de $5 \mathrm{~g}$. Além disso, foram selecionadas pelotas com massas bem próximas, para que os ensaios de redução pudessem ser comparados.

Para a investigação preliminar com as pelotas para redução direta, foram realizados ensaios em uma termobalança acoplada a um espectrômetro de massa. Foram realizados ensaios em diferentes isotermas sendo elas: $700{ }^{\circ} \mathrm{C}, 800^{\circ} \mathrm{C}, 900{ }^{\circ} \mathrm{C}, 1000{ }^{\circ} \mathrm{C}$ e $1100{ }^{\circ} \mathrm{C}$. O fluxo de gás redutor foi utilizado somente quando atingia a isoterma. $\mathrm{O}$ material permanecia em atmosfera inerte $\left(\mathrm{N}_{2}\right)$ durante o aquecimento e durante o resfriamento. $\mathrm{O}$ fluxo de gás redutor permanecia constante durante o tempo de 1 hora em cada temperatura. Em cada temperatura foram utilizados os fluxos $(50,100,150$ e $200 \mathrm{~mL} / \mathrm{min})$ de 
gás redutor (10\% de hidrogênio e $90 \%$ de argônio) sendo que para o gás utilizado o fluxo máximo permitido na termobalança era de $200 \mathrm{~mL} / \mathrm{min}$.

A Tabela 5 mostra os ensaios preliminares que foram realizados.

Tabela 5: Ensaios preliminares realizados com pelotas para redução direta.

\begin{tabular}{|c|c|c|c|c|}
\hline $\begin{array}{c}\text { Nome do } \\
\text { ensaio }\end{array}$ & Temperatura & Atmosfera & Fluxo & $\begin{array}{c}\text { Tempo da } \\
\text { isoterma }\end{array}$ \\
\hline PRD75 & $700{ }^{\circ} \mathrm{C}$ & $10 \% \mathrm{H}_{2}+90 \% A r$ & $50 \mathrm{~mL} / \mathrm{min}$ & 1 hora \\
\hline PRD71 & $700^{\circ} \mathrm{C}$ & $10 \% \mathrm{H}_{2}+90 \% \mathrm{Ar}$ & $100 \mathrm{~mL} / \mathrm{min}$ & 1 hora \\
\hline PRD715 & $700{ }^{\circ} \mathrm{C}$ & $10 \% \mathrm{H}_{2}+90 \% A r$ & $150 \mathrm{~mL} / \mathrm{min}$ & 1 hora \\
\hline PRD720 & $700{ }^{\circ} \mathrm{C}$ & $10 \% \mathrm{H}_{2}+90 \% A r$ & $200 \mathrm{~mL} / \mathrm{min}$ & 1 hora \\
\hline PRD85 & $800{ }^{\circ} \mathrm{C}$ & $10 \% \mathrm{H}_{2}+90 \% A r$ & $50 \mathrm{~mL} / \mathrm{min}$ & 1 hora \\
\hline PRD81 & $800{ }^{\circ} \mathrm{C}$ & $10 \% \mathrm{H}_{2}+90 \% A r$ & $100 \mathrm{~mL} / \mathrm{min}$ & 1 hora \\
\hline PRD785 & $800{ }^{\circ} \mathrm{C}$ & $10 \% \mathrm{H}_{2}+90 \% A r$ & $150 \mathrm{~mL} / \mathrm{min}$ & 1 hora \\
\hline PRD820 & $800{ }^{\circ} \mathrm{C}$ & $10 \% \mathrm{H}_{2}+90 \% A r$ & $200 \mathrm{~mL} / \mathrm{min}$ & 1 hora \\
\hline PRD95 & $900{ }^{\circ} \mathrm{C}$ & $10 \% \mathrm{H}_{2}+90 \% A r$ & $50 \mathrm{~mL} / \mathrm{min}$ & 1 hora \\
\hline PRD91 & $900{ }^{\circ} \mathrm{C}$ & $10 \% \mathrm{H}_{2}+90 \% A r$ & $100 \mathrm{~mL} / \mathrm{min}$ & 1 hora \\
\hline PRD915 & $900{ }^{\circ} \mathrm{C}$ & $10 \% \mathrm{H}_{2}+90 \% A r$ & $150 \mathrm{~mL} / \mathrm{min}$ & 1 hora \\
\hline PRD920 & $900{ }^{\circ} \mathrm{C}$ & $10 \% \mathrm{H}_{2}+90 \% A r$ & $200 \mathrm{~mL} / \mathrm{min}$ & 1 hora \\
\hline PRD105 & $1000{ }^{\circ} \mathrm{C}$ & $10 \% \mathrm{H}_{2}+90 \% A r$ & $50 \mathrm{~mL} / \mathrm{min}$ & 1 hora \\
\hline PRD101 & $1000{ }^{\circ} \mathrm{C}$ & $10 \% \mathrm{H}_{2}+90 \% A r$ & $100 \mathrm{~mL} / \mathrm{min}$ & 1 hora \\
\hline PRD1015 & $1000{ }^{\circ} \mathrm{C}$ & $10 \% \mathrm{H}_{2}+90 \% A r$ & $150 \mathrm{~mL} / \mathrm{min}$ & 1 hora \\
\hline PRD1020 & $1000{ }^{\circ} \mathrm{C}$ & $10 \% \mathrm{H}_{2}+90 \% A r$ & $200 \mathrm{~mL} / \mathrm{min}$ & 1 hora \\
\hline PRD115 & $1100{ }^{\circ} \mathrm{C}$ & $10 \% \mathrm{H}_{2}+90 \% A r$ & $50 \mathrm{~mL} / \mathrm{min}$ & 1 hora \\
\hline PRD111 & $1100{ }^{\circ} \mathrm{C}$ & $10 \% \mathrm{H}_{2}+90 \% A r$ & $100 \mathrm{~mL} / \mathrm{min}$ & 1 hora \\
\hline PRD1115 & $1100{ }^{\circ} \mathrm{C}$ & $10 \% \mathrm{H}_{2}+90 \% A r$ & $150 \mathrm{~mL} / \mathrm{min}$ & 1 hora \\
\hline PRD1120 & $1100{ }^{\circ} \mathrm{C}$ & $10 \% \mathrm{H}_{2}+90 \% A r$ & $200 \mathrm{~mL} / \mathrm{min}$ & 1 hora \\
\hline
\end{tabular}

\subsection{Ensaios de redução}

Para a realização dos ensaios de redução dos pellets feed A, B e C, foi necessário realizar a preparação destes. Nesta seção, são descritos as etapas pelotização dos pellets feed e classificação, secagem e queima das pelotas. 


\subsubsection{Preparação dos pellets feed A, B e C}

A preparação consistiu na pelotização dos pellets feed, após estes terem sido homogeneizados e quarteados, foi realizada a classificação, secagem e sinterização das pelotas produzidas.

Com as pelotas produzidas dos pellets feed $\mathrm{A}, \mathrm{B}$ e $\mathrm{C}$, foram realizados ensaios de redução na termobalança e no forno tubular horizontal. Estes ensaios serão descritos nas seções a seguir.

\subsubsection{Pelotização}

A pelotização foi realizada em um disco pelotizador em escala de laboratório. Inicialmente foi utilizada água como aglomerante para os três pellets feed A, B e C. Sendo que em dois tipos de pellets feed (A e B) a aglomeração utilizando somente água não foi suficiente para manter a integridade das pelotas após a etapa de secagem. A partir deste resultado, foi necessário adicionar aglomerante aos pellets feed A e B. A bentonita foi escolhida como aglomerante, por ser utilizada em processos de aglomeração de minério de ferro. Foram adicionados $0,05 \%$ em massa de bentonita e água aos pellets feed $\mathrm{A}$ e $\mathrm{B}$. $\mathrm{O}$ processo de pelotização iniciava-se com 0 acionamento do disco pelotizador, quando este estava em movimento colocava-se o pellet feed ao poucos no disco. O material era então aspergido com água e também colocava-se mais pellet feed conforme visualmente percebia a necessidade. A inclinação do disco era variada conforme a necessidade. A Figura 25 mostra imagens do disco pelotizador e do disco pelotizador com pellet feed sendo pelotizado. 


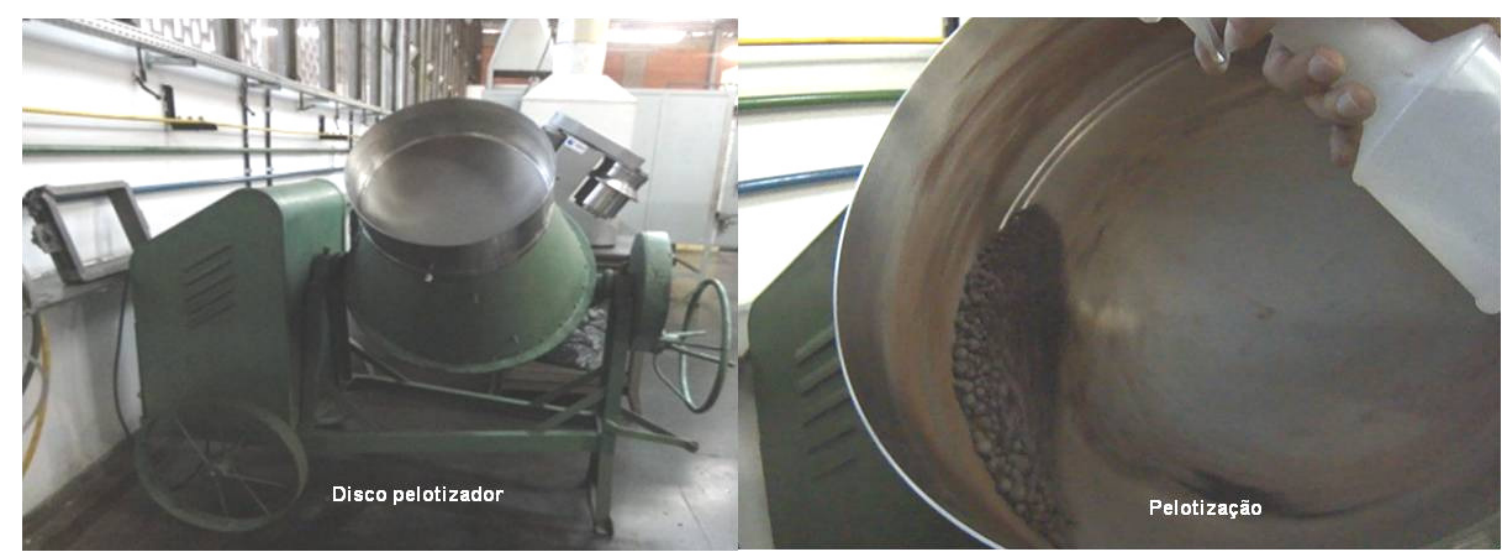

Figura 25: Disco pelotizador usado para aglomerar os minérios.

\subsubsection{Classificação}

Com o intuito de se ter um lote o mais homogêneo possível de pelotas de cada tipo de minério, foi realizado uma classificação de tamanho por peneiramento. Durante o processo de pelotização, quando as pelotas ainda estavam verdes, foram selecionadas pelotas passantes pela peneira com abertura de $12 \mathrm{~mm}$ e retidas na peneira com abertura de $9,52 \mathrm{~mm}$. A Figura 26 mostra os equipamentos utilizados na pelotização e classificação das pelotas.

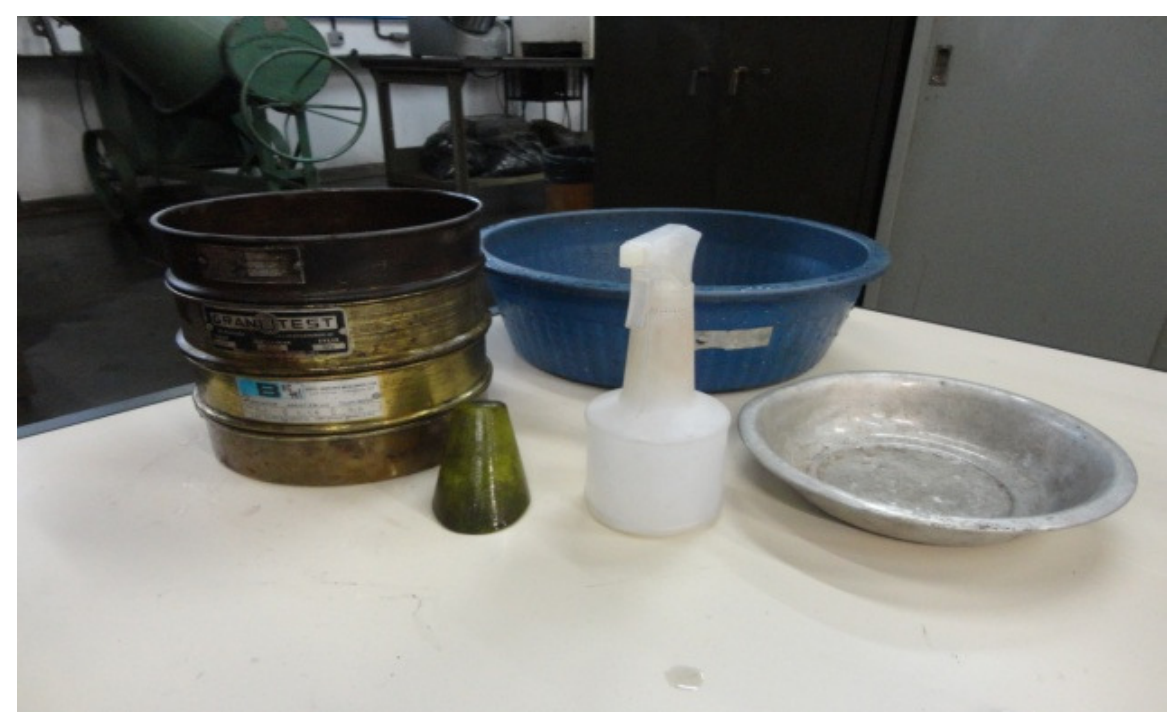

Figura 26: Equipamentos utilizados na aglomeração dos minérios e na classificação das pelotas. 


\subsubsection{Secagem}

Após a aglomeração dos três pellets feed e classificação das pelotas, estas foram colocadas em bandejas de aço e mantidas em um forno mufla a uma temperatura de $100{ }^{\circ} \mathrm{C}$ por 24 horas para retirar a umidade livre. A Figura 27 mostra as pelotas colocadas em bandejas de aço prontas para serem secas.

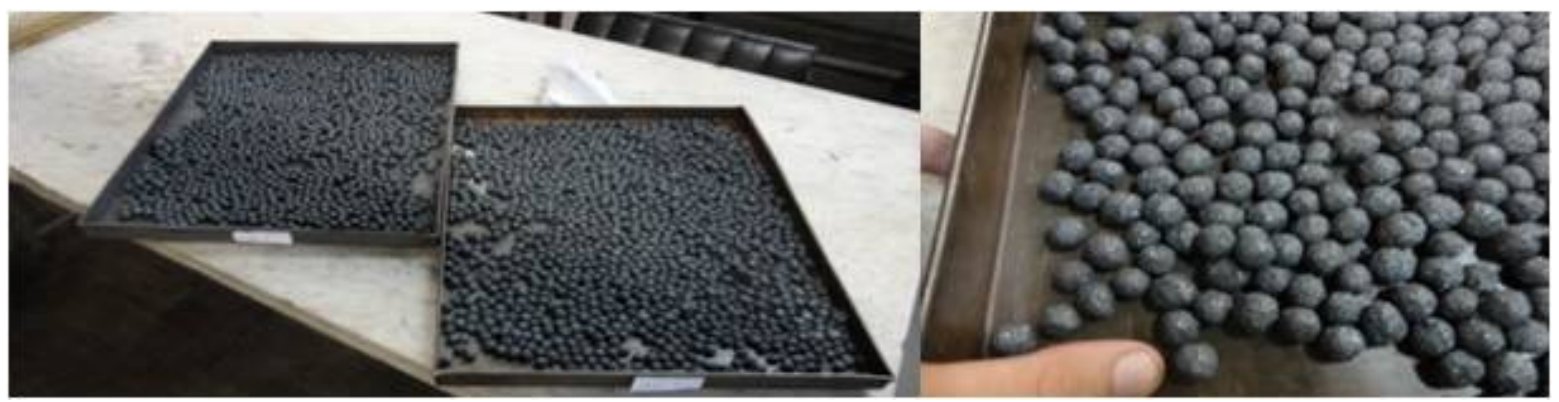

Figura 27: Pelotas dispostas em bandejas de aço, prontas para serem secadas.

\subsubsection{Sinterização (queima) das pelotas}

Foi realizada a queima das pelotas em um forno Tubular Marca INTI modelo Mufla T/17000. A temperatura de queima foi de $1275^{\circ} \mathrm{C}$ por um tempo de aproximadamente de 9 minutos [93]. Estas condições foram levantadas por Costa, 2008. Para realizar a queima, as pelotas foram colocadas em uma navícula de alumina que foi levada ao forno. A Figura 28 mostra a imagem das pelotas na navícula dentro do forno sendo queimadas.

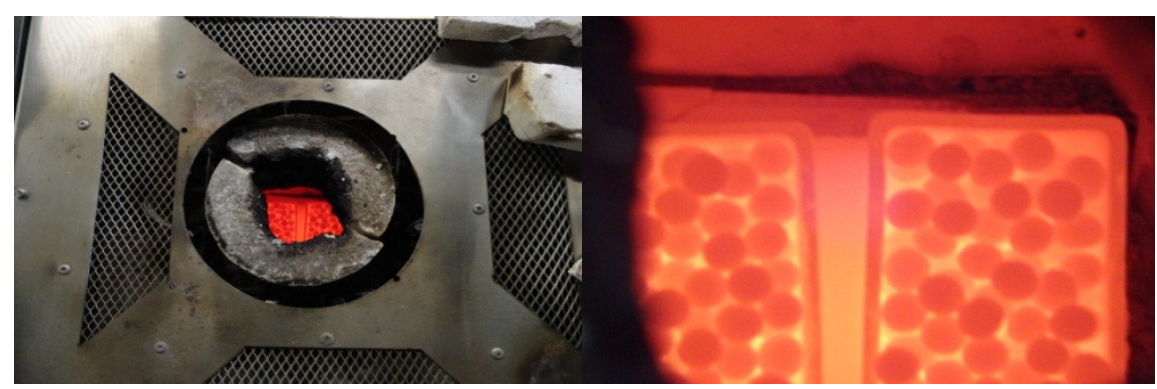

Figura 28: Navícula com pelotas dentro do forno para realizar a queima das pelotas (sinterização). 


\subsubsection{Ensaios no forno tubular}

Com o intuito de se investigar a morfologia das pelotas durante 0 processo de redução por hidrogênio e hidrogênio mais monóxido de carbono foram realizados ensaios das pelotas dos pellets feed A, B e C em um forno elétrico tubular horizontal. Este forno fica localizado dentro de uma capela que possui um sistema de exaustão, evitando-se o acumulo de gás no local. Os ensaios foram realizados na temperatura de $850{ }^{\circ} \mathrm{C}$. A escolha da temperatura de $850{ }^{\circ} \mathrm{C}$ foi baseada nos ensaios preliminares e na literatura. As pelotas dos pellets feed A, B e C foram colocadas em um suporte refratário de alumina que foi inserido no forno. Foi realizado o aquecimento das amostras dentro do forno até a temperatura de $850^{\circ} \mathrm{C}$ sob o fluxo de nitrogênio. Após atingida e estabilizada a temperatura, o fluxo de gás inerte era substituído por um fluxo de gás redutor (hidrogênio ou hidrogênio mais monóxido de carbono). As amostras foram retiradas do forno em tempos espaçados de 15, 30, 45, 60, 90, 120, 150, 210, 270, 330, 390 e 450 minutos e resfriadas sob atmosfera de nitrogênio. As pelotas dos pellets feed A, B e C foram ensaiadas ao mesmo tempo. Foi retirada em cada tempo uma pelota de cada um dos três tipos de pelotas.

Nos ensaios realizados no forno com as pelotas dos pellets feed A, B e C para a investigação da morfologia das pelotas, foram estudadas duas atmosferas redutoras:

1. (10\% de hidrogênio e $90 \%$ de argônio).

2. (( $10 \%$ de hidrogênio e $90 \%$ de argônio $)+(($ monóxido de carbono) ou seja a fração redutora é composta por (75\% de hidrogênio e $25 \%$ de monóxido de carbono).

A composição e fluxo da atmosfera 2 foram estabelecidos afim de se ter uma composição aproximada à do gás natural reformado. Com isso a composição da atmosfera 2 em relação aos gases redutores, é composta por $25 \%$ de monóxido de carbono e $75 \%$ de hidrogênio. 
Utilizou-se um forno elétrico, marca Lindberg Blue, com temperatura de trabalho até $1200^{\circ} \mathrm{C}$.

O forno horizontal foi conectado a um controlador de temperatura Lindberg Blue. A tensão de operação do forno era de 208/240 V.

O comprimento da zona mais aquecida do forno e de temperatura constante era de $18 \mathrm{~cm}$. Um tubo de mulita, $115 \mathrm{~cm}$ de comprimento, $7,3 \mathrm{~cm}$ de diâmetro externo e $0,9 \mathrm{~cm}$ de espessura foi introduzido no forno horizontal e funcionou como retorta, permitindo o controle da atmosfera interna do forno.

No interior do tubo de mulita, foi colocado o suporte refratário de alumina com as pelotas. Dois flanges de aço inoxidável vedavam as extremidades do tubo de mulita.

Os flanges possuíam aberturas para diversas funções. O flange possui $20 \mathrm{~cm}$ de diâmetro e era refrigerado com água e possuía orifícios para entrada gases para o interior do aparato, entrada para coleta de amostra, saída para gases gerados e injetados na retorta e visor.

O controle do fluxo dos gases de entrada foi feito utilizando um Controlador de fluxo mássico da MKS modelo 647B com 4 canais.

Os gases eram armazenados em cilindros de aço. O controle de pressão dos gases era feita por reguladores de pressão primários próximo aos cilindros e em seguida por reguladores de pressão na linha de gás. Estes reguladores ficavam antes do controlador de fluxo mássico garantindo que a pressão dos gases antes do controlador de fluxo mássico fosse constante.

A Figura 29 mostra o aparato experimental constituído por forno tubular horizontal com retorta de mulita e flanges, reguladores de pressão, controlador de fluxo mássico e controlador de temperatura do forno. 


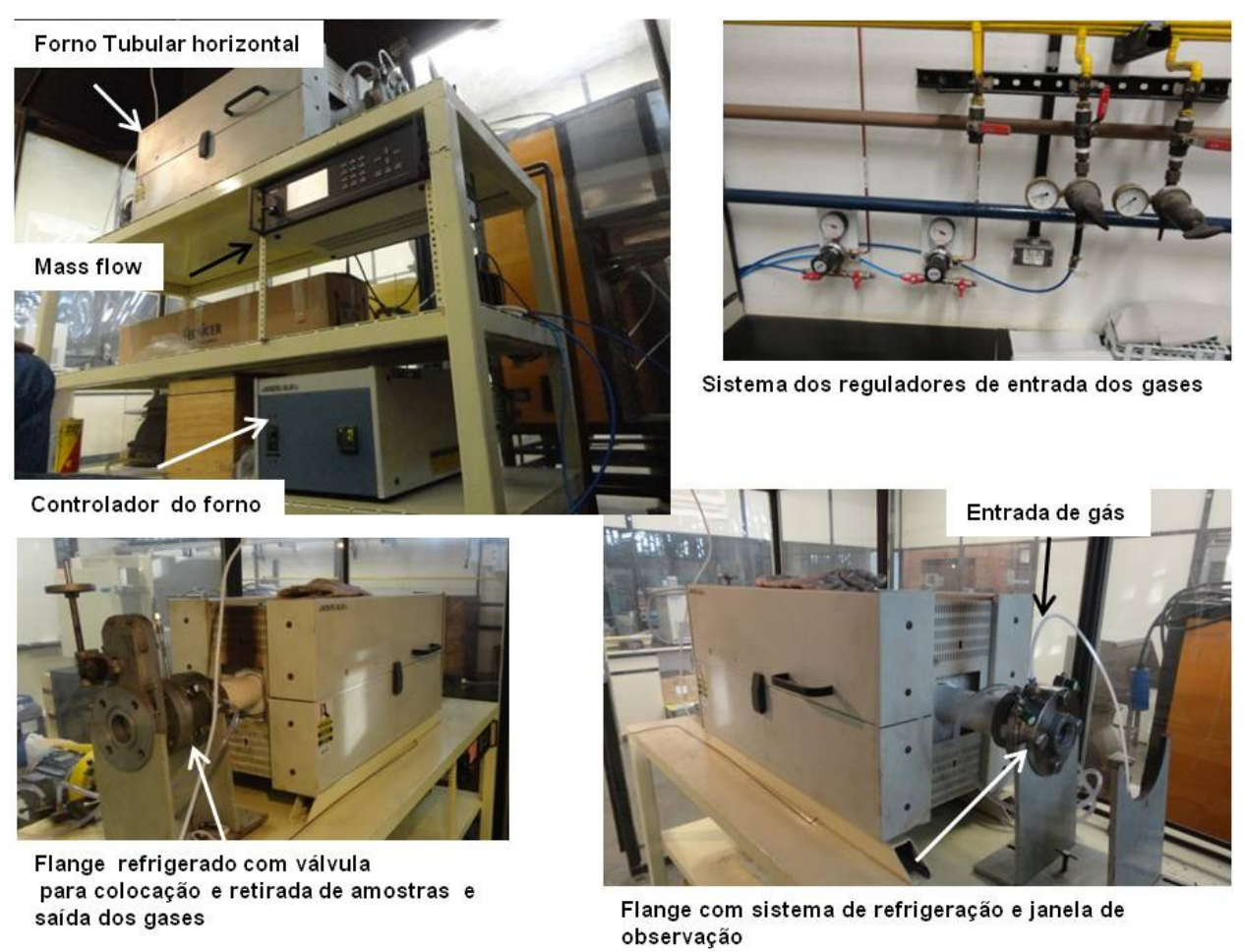

Figura 29: Imagens do aparato experimental utilizado para os ensaios no forno tubular.

A Figura 30 mostra o suporte refratário com as pelotas dos pellets feed A, B e C e também o suporte com as amostras dentro do forno.

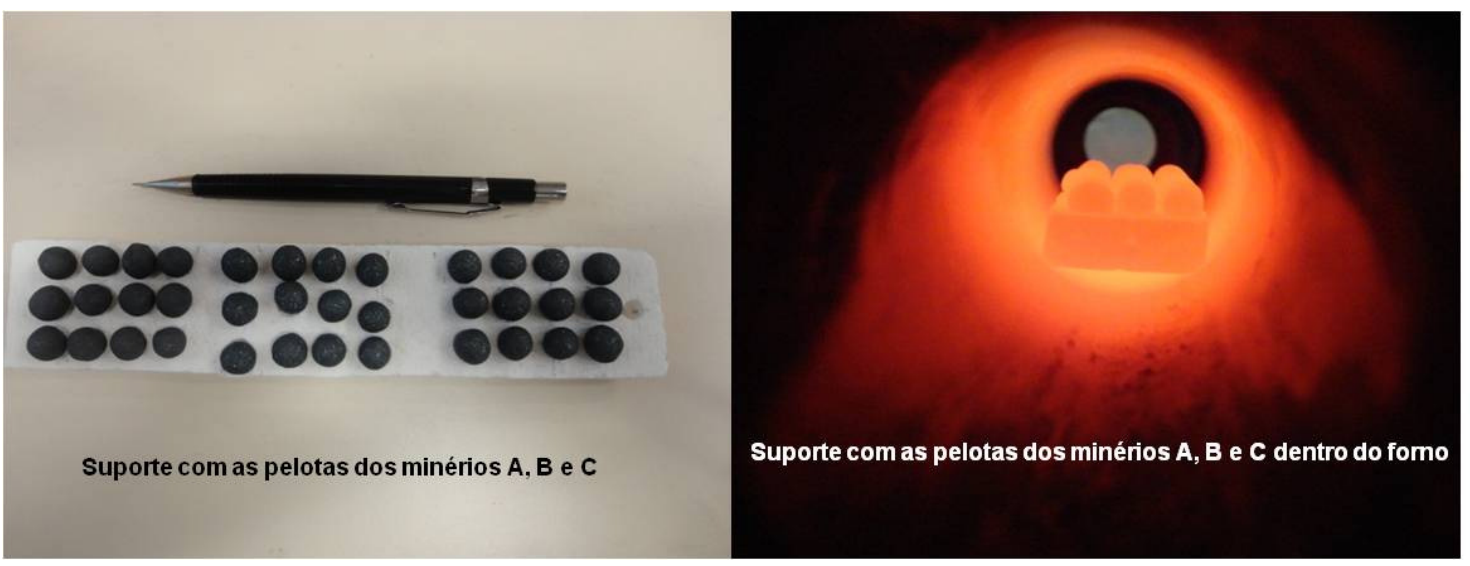

Figura 30: Detalhe do suporte com as pelotas dos pellets feed e suporte com as amostras dentro do forno. 


\subsubsection{Análise termogravimétrica (ATG)}

A análise de redução em termobalança utilizou duas metodologias: análise isotérmica e quasi-isotérmica por passos, esta última denominada "stepwise isothermal analysis (SIA)" [93]

Inicialmente foram feitos ensaios com pelotas para redução direta utilizando isotermas com 1 hora de duração nas temperaturas de $700{ }^{\circ} \mathrm{C}$, $800{ }^{\circ} \mathrm{C}, 900{ }^{\circ} \mathrm{C}, 1000{ }^{\circ} \mathrm{C}$ e $1100{ }^{\circ} \mathrm{C}$. Foram utilizados fluxos de 50, 100, 150 e $200 \mathrm{~mL} / \mathrm{min}$ de gás redutor (10\% de hidrogênio $+90 \%$ de argônio) afim de estabelecer condições experimentais.

Posteriormente, e após estabelecidas algumas condições experimentais, foram realizados os ensaios com as pelotas obtidas dos pellets feed A, B e C. Nestes ensaios de redução foram utilizados vários patamares de 15 minutos a cada $50^{\circ} \mathrm{C}$, desde $500^{\circ} \mathrm{C}$ até $1100^{\circ} \mathrm{C}$. As atmosferas redutoras empregradas neste estudo foram:

1. ( $10 \%$ de hidrogênio e $90 \%$ de argônio) fluxo de $200 \mathrm{~mL} / \mathrm{min}$.

2. (( $10 \%$ de hidrogênio e $90 \%$ de argônio) $180 \mathrm{~mL} / \mathrm{min}+(($ monóxido de carbono) fluxo de $6 \mathrm{~mL} / \mathrm{min}$ )) ou seja, a fração dos gases redutores é composta por $75 \%$ de hidrogênio e $25 \%$ de monóxido de carbono.

A composição e fluxo da atmosfera 2 foram estabelecidos para se ter uma composição aproximada de gás natural reformado.

$\mathrm{O}$ equipamento utilizado para o estudo do comportamento térmico e ensaios de redução foi uma termobalança simultânea Netzsch, modelo STA 449 F1, acoplada a um espectrômetro de massa Netzsch, modelo QMS 403C. Ambos os instrumentos são conectados a um computador para controle da, aquisição e processamento dos dados.

Tabela 6 mostra os ensaios de redução realizados em termobalança com as pelotas dos pellets feed A, B e C. 
Tabela 6: Ensaios de redução em diferentes atmosferas das pelotas dos pellets feed A, B e C.

\begin{tabular}{|l|l|c|c|c|c|}
\hline $\begin{array}{c}\text { Nome do } \\
\text { ensaio }\end{array}$ & $\begin{array}{c}\text { Intervalo de } \\
\text { temperatura }\end{array}$ & Atmosfera & Fluxo & $\begin{array}{c}\text { Tempo } \\
\text { de cada } \\
\text { isoterma }\end{array}$ & $\begin{array}{c}\text { Tempo } \\
\text { total de } \\
\text { isotermas }\end{array}$ \\
\hline PFA112H & $500-1100{ }^{\circ} \mathrm{C}$ & $\begin{array}{c}\text { Mistura } \\
\left(10 \% \mathrm{H}_{2}+90 \% \mathrm{Ar}\right)\end{array}$ & $200 \mathrm{~mL} / \mathrm{min}$ & $15 \mathrm{~min}$ & $195 \mathrm{~min}$ \\
\hline PFB112H & $500-1100{ }^{\circ} \mathrm{C}$ & $\begin{array}{c}\text { Mistura } \\
\left(10 \% \mathrm{H}_{2}+90 \% \mathrm{Ar}\right)\end{array}$ & $200 \mathrm{~mL} / \mathrm{min}$ & $15 \mathrm{~min}$ & $195 \mathrm{~min}$ \\
\hline PFC112H & $500-1100{ }^{\circ} \mathrm{C}$ & $\begin{array}{c}\text { Mistura } \\
\left(10 \% \mathrm{H}_{2}+90 \% \mathrm{Ar}\right)\end{array}$ & $200 \mathrm{~mL} / \mathrm{min}$ & $15 \mathrm{~min}$ & $195 \mathrm{~min}$ \\
\hline PFA112CH & $500-1100{ }^{\circ} \mathrm{C}$ & $\begin{array}{c}\text { Mistura }\left(\left(10 \% \mathrm{H}_{2}+\right.\right. \\
90 \% \mathrm{Ar})+100 \% \mathrm{CO})\end{array}$ & $186 \mathrm{~mL} / \mathrm{min}$ & $15 \mathrm{~min}$ & $195 \mathrm{~min}$ \\
\hline PFB112CH & $500-1100{ }^{\circ} \mathrm{C}$ & $\begin{array}{c}\text { Mistura }\left(\left(10 \% \mathrm{H}_{2}+\right.\right. \\
90 \% A r)+100 \% \mathrm{CO})\end{array}$ & $186 \mathrm{~mL} / \mathrm{min}$ & $15 \mathrm{~min}$ & $195 \mathrm{~min}$ \\
\hline PFC112CH & $500-1100{ }^{\circ} \mathrm{C}$ & $\begin{array}{c}\text { Mistura }\left(\left(10 \% \mathrm{H}_{2}+\right.\right. \\
90 \% A r)+100 \% \mathrm{CO})\end{array}$ & $186 \mathrm{~mL} / \mathrm{min}$ & $15 \mathrm{~min}$ & $195 \mathrm{~min}$ \\
\hline
\end{tabular}

O espectrômetro de massa Netzsch QMS 403C foi acoplado à saída do gás, no topo da balança termogravimétrica, através de um capilar de quartzo aquecido a $300^{\circ} \mathrm{C}$. Este procedimento tem por finalidade evitar a condensação desde a saída até o sensor quadripolar. O equipamento possui duas formas de medição: varredura de massas moleculares em intervalos de tempo ou medida dos teores de gases evoluídos, previamente selecionados, em determinados intervalos de tempo.

Para uma maior acurácia dos resultados em todos os experimentos realizados na termobalança foi realizado o ensaio com o fluxo correspondente e sem amostra na termobalança para posterior subtração da curva de perda de massa. A análise sem a amostra, correspondente ao branco do equipamento evita possíveis erros de sinal e garante que a curva do ensaio leve em consideração apenas a perda de massa da pelota devido à redução.

A Figura 31 mostra a imagem da termobalança utilizada, do espectrômetro e detalhes de como a amostra era suportada na termobalança. 


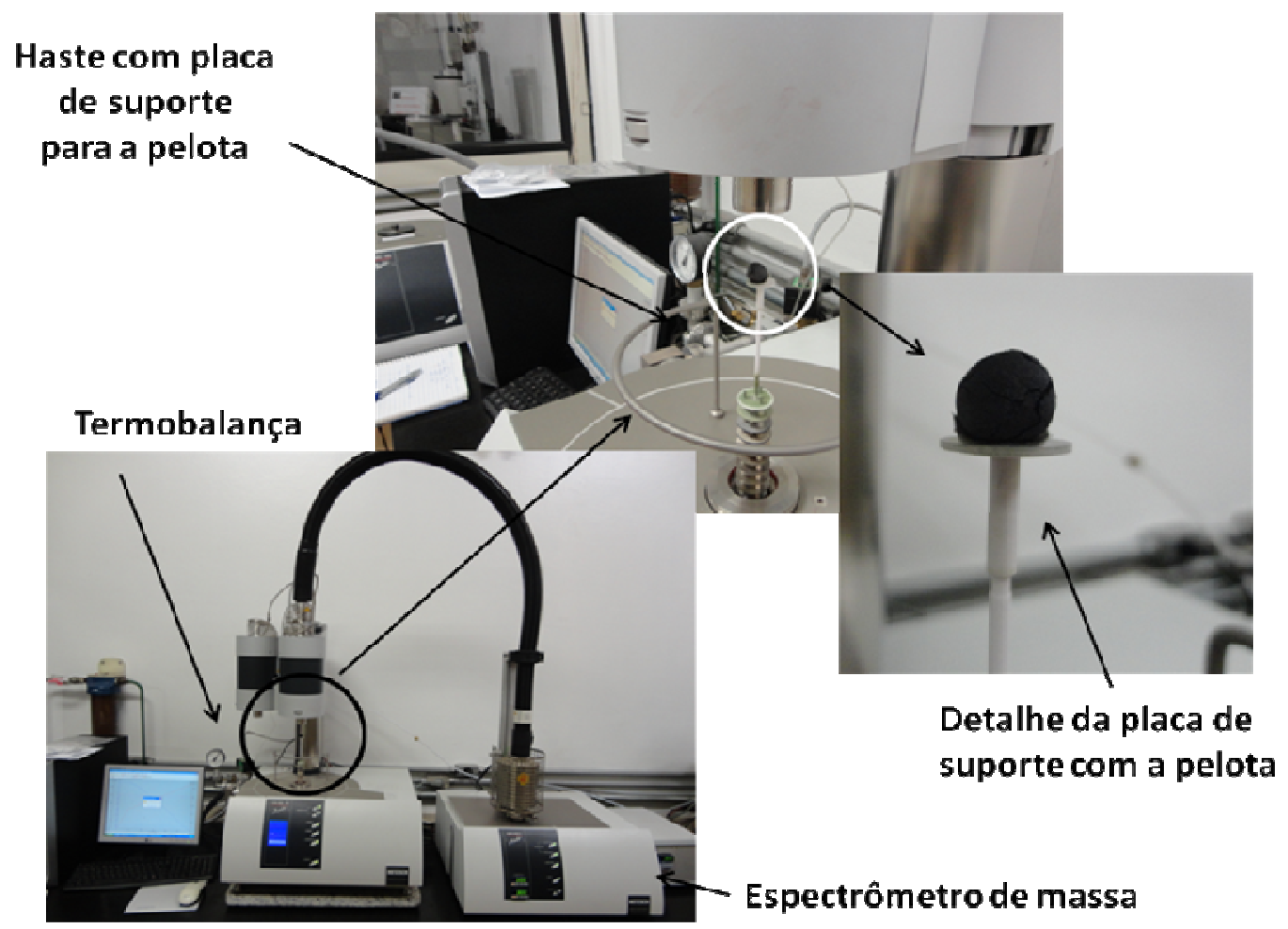

Figura 31: Aparato utilizado para estudo da redução das pelotas de minério de ferro.

\subsection{Procedimentos de investigação cinética}

Para a investigação cinética neste trabalho utilizaram-se dois métodos, o "Forced Stepwise Isothermal Analysis" FSIA e o método "Jump". Ambos se aplicam a estudos cinéticos em análise termogravimétrica.

No caso do método FSIA foi empregada uma estratégia análoga à utilizada por Restivo, 2003 [94].

\subsubsection{Método SIA forçado}

O trabalho de Restivo [94] baseia-se no método conhecido como "Forced Stepwise Isothermal Analysis" (FSIA). Esse método é uma variante do 
SIA o qual estuda a cinética das reações através do estabelecimento de diversos patamares de temperaturas e rampas de aquecimento entre estes patamares, sendo proposto por Sorensen [95, 96, 97, 98, 99, 100, 101, 102, $103,104,105,106]$.

No método FSIA [107,108] são fixadas as quantidades e as temperaturas dos patamares, bem como os tempos de cada patamar, também se escolhe a velocidade de aquecimento nas rampas.

O método estuda a cinética dos eventos térmicos em cada um dos degraus ou patamares ("steps"). Procura-se assim ajustar a melhor equação cinética para cada patamar. No caso deste estudo os eventos são as reações de redução.

Como o método é desenvolvido em isotermas discretas e consecutivas as eventuais reações sobrepostas em cada uma das temperaturas podem ficar mais evidentes. Assim, o método permite a separação de eventos sobrepostos de forma mais clara, o que permite, nesse caso, o cálculo mais preciso das Energias de Ativação aparentes e dos mecanismos de reação envolvidos. Além disso, as temperaturas ou intervalos de cada um dos eventos podem ser melhor identificados. Por fim, uma análise mais completa pode ser feita em apenas um ensaio.

Para cada um dos patamares podem ser feitas essencialmente duas abordagens cinéticas [109, 110]:

1) Método Diferencial: $d \alpha / d t=k \cdot f(\alpha)$

2) Método Integral: $g(\alpha)=k . t$

onde: $g(\alpha)=\int 1 / f(\alpha) d \alpha$

$\alpha$ é a fração reagida.

k é a constante de velocidade.

O trabalho de Dickinson revisa a literatura existente sobre os modelos cinéticos aplicados em eventos térmicos. Por outro lado Browin et al. [111] indica que a equação de Sestak-Berggren contempla quase todos os modelos cinéticos propostos para eventos térmicos: 


$$
d \alpha / d t=k \cdot \alpha^{m} \cdot(1-\alpha)^{n} \cdot[-\ln (1-\alpha)]^{p} \quad \text { Equação } 7
$$

. Neste estudo foram traçadas curvas curvas da/dt em função de alfa $f(\alpha)$ para $f(\alpha)=\alpha ; f(\alpha)=(1-\alpha) ; f(\alpha)=[-\ln (1-\alpha)]$. Onde $\alpha$ é a fração reagida.

Considerando-se que o minério de ferro pode conter frações de hematita, magnetita e goethita, usou-se a equação para o cálculo da fração reagida $\alpha$ :

$$
\mathrm{X}_{\mathrm{H}} \mathrm{Fe}_{2} \mathrm{O}_{3}+\mathrm{X}_{\mathrm{M}} \mathrm{Fe}_{3} \mathrm{O}_{4}+\mathrm{X}_{\mathrm{G}} \alpha \mathrm{HFeO}_{2} \quad \text { Equação } 8
$$

Onde:

$X_{H}=$ fração de hematita

$X_{M}=$ fração de magnetita

$X_{G}=$ fração de goethita.

O balanço do Fe é dado por:

$$
X_{H} \cdot 2+X_{M} \cdot 3+X_{G} \cdot 1=T_{F e} \text { mols } \quad T_{F e} / T_{F e}=1
$$

Enquanto que o Oxigênio é dado por: $X_{H} \cdot 3+X_{M} \cdot 4+X_{G} \cdot 2=T_{O}$ mols $T_{O} / T_{F e}=Y_{O}$

Resultando em:

$$
\mathrm{FeOY} \mathrm{O}_{\mathrm{O}}+\mathrm{Y}_{\mathrm{O}} \mathrm{H}_{2} \rightarrow \mathrm{Fe}+\mathrm{Y}_{\mathrm{O}} \mathrm{H}_{2} \mathrm{O} \quad \text { Equação } 9
$$

Caso ocorra a redução completa dos óxidos de ferro a perda de massa total é dada por:

$$
D_{m}=\left(\left(\left(56 \cdot Y_{O}\right)-56\right) /\left(56 \cdot Y_{O}\right)\right)=D_{m} \% \quad \text { Equação } 10
$$

Consequentemente a fração reagida $\alpha$ é dada por: 


$$
\alpha(t)=\frac{\left(m_{O}-m(t)\right)}{\left(m_{O}-\left(m_{O} \cdot\left(1-\left(D_{m} \% / 100\right)\right)\right)\right)} \quad \text { Equação } 11
$$

Onde:

$\mathrm{m}_{0}=$ massa inicial da pelota

$\mathrm{m}(\mathrm{t})=$ massa da pelota no tempo $\mathrm{t}$ medida na termobalança.

\subsubsection{Método "Jump"}

No presente trabalho usou-se o método "Jump" associado às curvas obtidas no método FSIA para se obter as Energias de Ativação.

O método "Jump" [33, 61, 62, 63] foi desenvolvido para determinar energias de ativação de processos térmicos sem que se conheça a equação, ou seja, o mecanismo do processo tanto químico quanto de transporte de calor ou massa. Assim, esta metodologia de determinação de Energias de Ativação é também conhecida como modelo livre [43, 44, 47, 64].

Entre duas isotermicas consecutivas, 0 aumento da temperatura normalmente causa um aumento em da/dt, Assim:

- $(\mathrm{d \alpha} / \mathrm{dt})_{1}=A \cdot \exp \left(-E a / R T_{1}\right) \cdot f(\alpha),$, e:

- $(\mathrm{d} \alpha / \mathrm{dt})_{2}=\mathrm{A} \cdot \exp (-\mathrm{Ea} / \mathrm{RT} 2) \cdot \mathrm{f}(\alpha)$

Onde T1 e T2 são temperaturas de patamares adjacentes, sendo T1 inferior a T2, e as derivadas são tomadas respectivamente imediatamente antes do final da rampa T1 e no começo da rampa T2.

Dividindo-se uma pela outra resulta:

$$
\frac{\left(\frac{d \alpha}{d t}\right)_{1}}{\left(\frac{d \alpha}{d t}\right)_{2}}=\exp \left[\frac{E}{R}\left(\frac{1}{T_{2}}-\frac{1}{T_{1}}\right)\right] \Rightarrow \ln \frac{\left(\frac{d \alpha}{d t}\right)_{1}}{\left(\frac{d \alpha}{d t}\right)_{2}}=\left[\frac{E}{R}\left(\frac{1}{T_{2}}-\frac{1}{T_{1}}\right)\right] \text { Equação } 12
$$

Assim, durante o salto, a função que descreve a variação da fração reagida tem que ser invariante. 


\section{Resultados e Discussão}

Nesta seção são apresentados e discutidos os resultados para os ensaios realizados com:

- Pelotas para redução direta (Ensaios preliminares): morfologia e redução das pelotas de redução direta reduzidas em diferentes isotermas e diferentes fluxos de gás redutor (10\% de hidrogênio + 90\% de argônio).

- Pellets feed A, B e C: Caracterização e quantificação das fases mineralógicas presentes, distribuição de tamanhos de partículas, área de superfície específica e morfologia das partículas.

- Pelotas dos pellets feed A, B e C: Análise cinética da redução, caracterização da morfologia da superfície das pelotas reduzidas e caracterização da morfologia da seção das pelotas parcialmente reduzidas.

\subsection{Ensaios de Redução (ensaios preliminares)}

São apresentados os resultados dos ensaios preliminares realizados com as pelotas de redução direta que foram reduzidas com (10\% de hidrogênio + $90 \%$ de argônio) na termobalança.

\subsubsection{Caracterização macroestrutural}

Após os ensaios de redução em diferentes isotermas e diferentes fluxos de gás redutor as pelotas para redução direta foram caracterizadas através de imagens obtidas em uma lupa.

A Figura 32 mostra a morfologia das pelotas reduzidas em diferentes temperaturas e diferentes fluxos de gás redutor $(10 \%$ de hidrogênio $+90 \%$ de argônio) 
Foi constatado visualmente e nota-se da Figura 32 que a morfologia das pelotas varia conforme a temperatura em que foi realizada a redução. A $80{ }^{\circ} \mathrm{C}$, as trincas e rachaduras são menores e em menor número do que as das pelotas reduzidas em temperaturas maiores que $900{ }^{\circ} \mathrm{C}$. Com o aumento da temperatura de redução, ocorre um aumento no tamanho das trincas. Isto fica mais evidenciado em temperaturas iguais e maiores que $1000{ }^{\circ} \mathrm{C}$.

Observa-se também na Figura 32 que a morfologia varia com a variação do fluxo de gás redutor. Com o aumento do fluxo de gás redutor, observa-se um aumento do tamanho das trincas, ficando mais evidenciado em temperaturas iguais e maiores que $900{ }^{\circ} \mathrm{C}$.

Uma explicação para o aparecimento de trincas e rachaduras é proposta por Meyers e Tantevee [112], conforme discutido na seção sobre o surgimento de fissuras e trincas em pelotas durante a redução. A teoria discutida anteriormente está relaciona as mudanças de volume associadas com as mudanças estruturais nas transformações da hematita para magnetita e magnetita para wustita que ocorrem durante a redução [112]. Ocorrendo uma mudança de $11 \%$ no volume durante a mudança de hematita para magnetita [112]. Por cálculos e considerando o peso específico da hematita de $\left(6,85 \mathrm{~g} / \mathrm{cm}^{3}\right)$ e magnetita $\left(5,81 \mathrm{~g} / \mathrm{cm}^{3}\right)$ e calculando a mudança da densidade e considerando a mudança no volume devido à perda de oxigênio chega-se a uma diminuição no volume de 9,8\%. Já a transformação de wustita para ferro encontra-se por cálculos uma contração de 5\% [112]. Conforme Meyers e Tantevee [112] e apartir da análise de tensões conduzidas, a transformação hematita-magnetita tenderá a produzir trincas circunferênciais e a transformação wustita-ferro tenderá a produzir trincas radiais. A magnitude das tensões é suficitente para produzir a fratura. As tensões geradas pelas reações excedem o limite de resistência dos pellets [112].

Portanto o surgimento de trincas está associado as mudanças de volume associados a redução das pelotas, e também devido a temperatura, pois a diferentes fases que surgem possuem coeficientes de dilatação diferentes. 


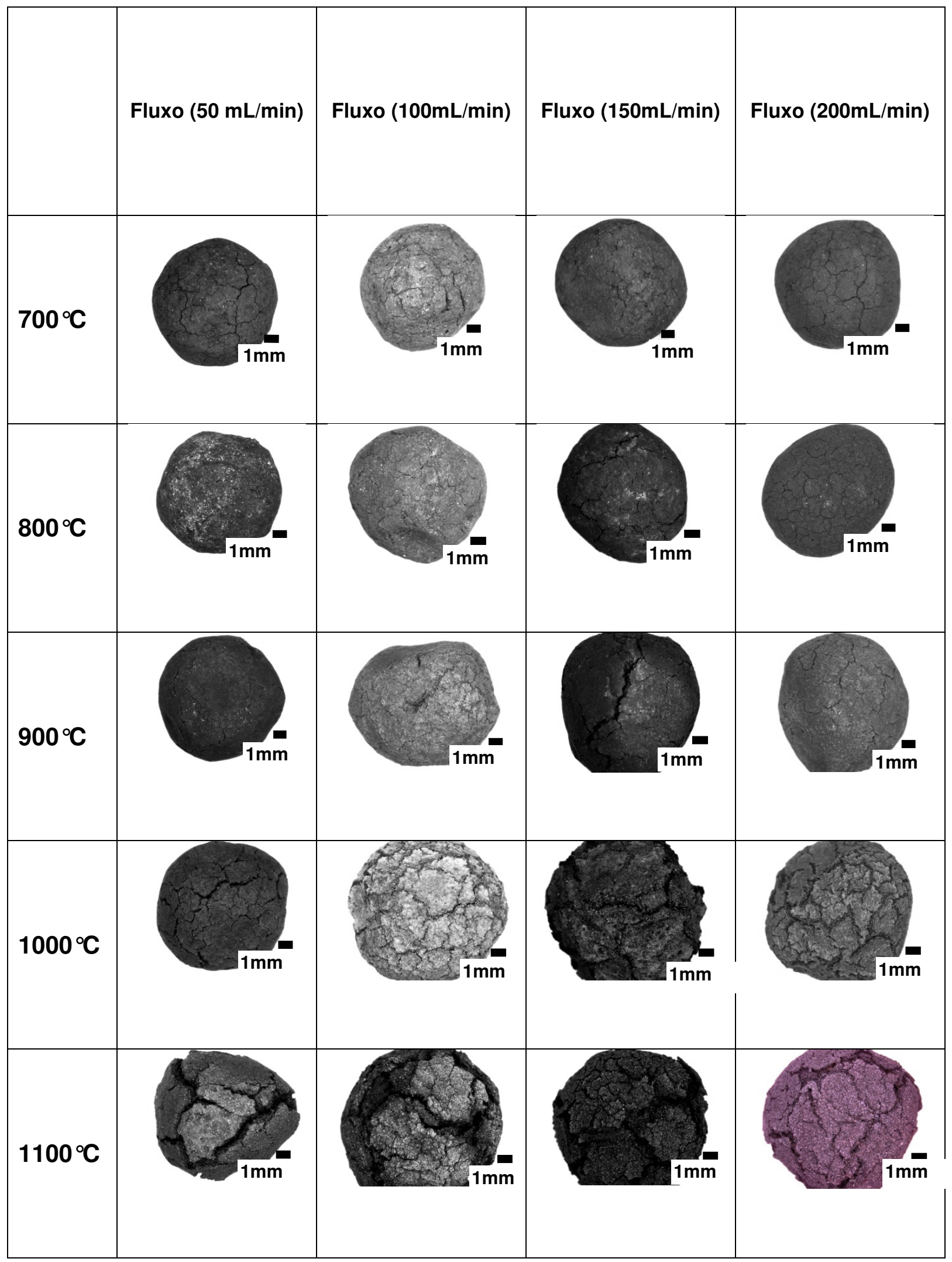

Figura 32: Morfologia das pelotas reduzidas em diferentes temperaturas e diferentes fluxos de gás redutor. 


\subsubsection{Ensaios de redução em termobalança (Ensaios preliminares)}

Conforme descrito na seção sobre os ensaios preliminares, estes ensaios de redução foram realizados com pelotas comerciais para redução direta em uma termobalança em diferentes fluxos de gás redutor $(10 \%$ de hidrogênio + 90\% de argônio) e diferentes temperaturas (700, 800, 900, 1000 e $\left.1100{ }^{\circ} \mathrm{C}\right)$ de isoterma. Nestes ensaios preliminares a pelota foi aquecida a uma taxa constante em atmosfera inerte (nitrogênio) até a temperatura da isoterma desejada. Atingida a temperatura da isoterma, a válvula do gás redutor era aberta permitindo o fluxo do gás redutor no ambiente da amostra dentro da termobalança. A amostra permanecia por 1 hora nesta atmosfera. Depois de atingido o tempo na isoterma, o fluxo de gás redutor era suspenso e a amostra era resfriada em atmosfera de nitrogênio até a temperatura ambiente.

A Figura 33 mostra as curvas de perda de massa (curvas de TG) dos ensaios de redução das pelotas de redução direta. A seqüência de cinco curvas mostradas foi submetida ao mesmo fluxo $(50 \mathrm{~mL} / \mathrm{min})$ de gás redutor ( $10 \%$ de hidrogênio + $90 \%$ de argônio) e mesmo tempo ( 1 hora) na isoterma na presença do gás redutor.

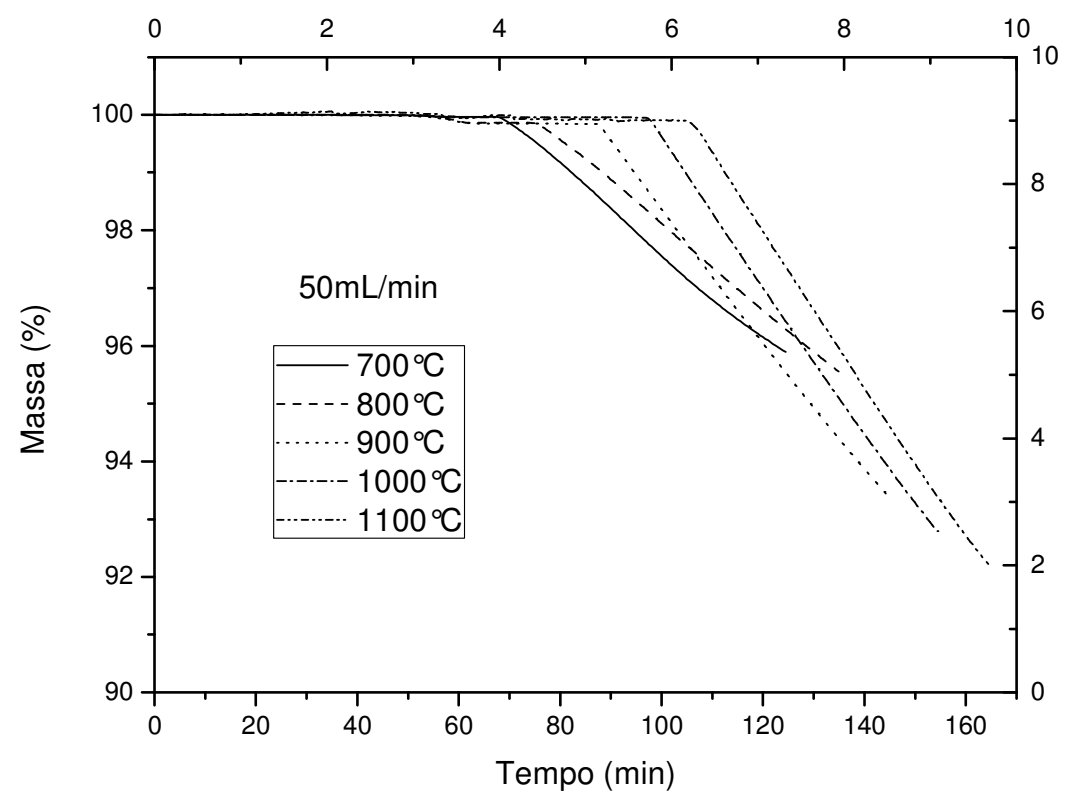

Figura 33: Massa versus tempo para pelota de redução direta ensaiada com fluxo de gás redutor ( $10 \%$ de hidrogênio $+90 \%$ de argônio) de $50 \mathrm{~mL} / \mathrm{min}$ a diferentes temperaturas $\left(700,800,900,1000\right.$ e $\left.1100^{\circ} \mathrm{C}\right)$ com 1 hora de duração em cada isoterma. 
Nota-se da Figura 33 uma variação na inclinação das curvas de redução. O ponto final de cada curva corresponde ao final do ensaio e final da perda de massa. Como todas as amostras permaneceram 1 hora nas isotermas em atmosfera redutora, fazendo a leitura do ponto final de cada curva no eixo y (variação da massa) e comparando os valores, conclui-se que, a amostra ensaiada na temperatura de $1100{ }^{\circ} \mathrm{C}$ foi a que teve a maior perda de massa. As amostras ensaiadas a 700 e $800{ }^{\circ} \mathrm{C}$ tiveram perdas de massas próximas, e foram as que tiveram menor perda de massa. Já as amostras ensaiadas em 900,1000 e $1100^{\circ} \mathrm{C}$ possuem perdas de massas próximas e apresentam maior perda de massa quando comparadas com as amostras ensaiadas a 700 e $800^{\circ} \mathrm{C}$.

As Figura 34, 39 e 40 mostram seqüencias de curvas de perda de massa em diferentes temperaturas e em fluxos de 100, 150 e $200 \mathrm{~mL}$ de gás redutor $\left(90 \% \mathrm{Ar}+10 \% \mathrm{H}_{2}\right)$ respectivamente.

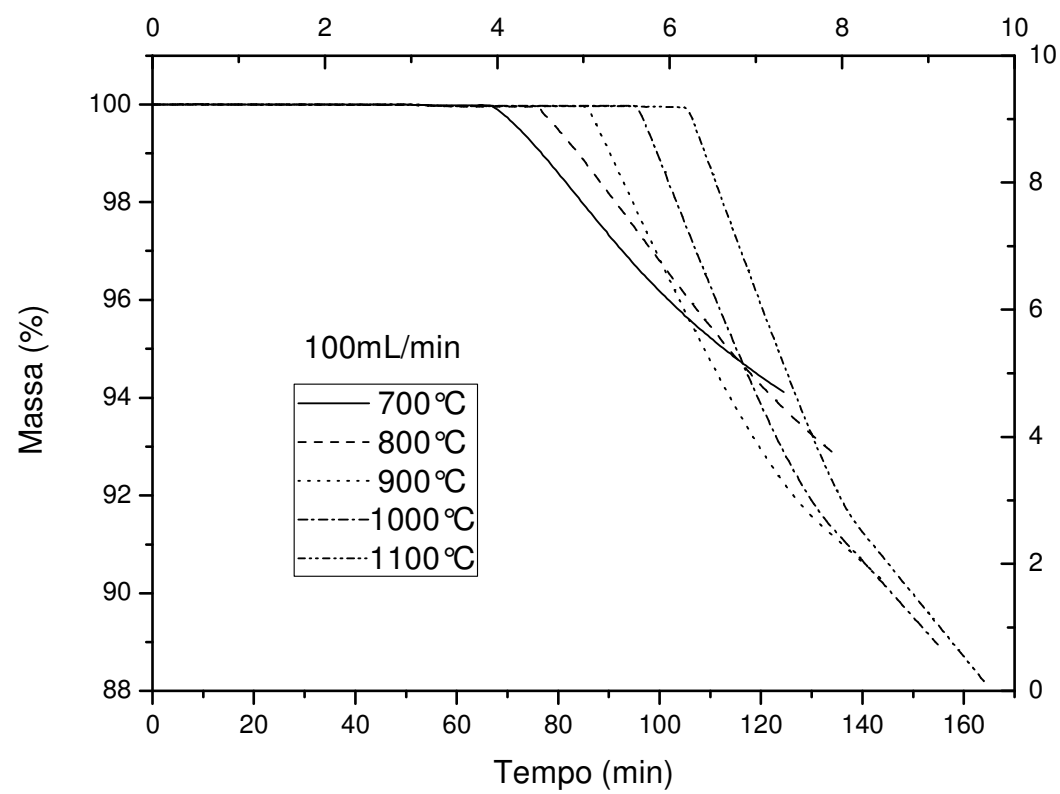

Figura 34: Massa versus tempo para pelota de redução direta ensaiada com fluxo de gás redutor (10\% de hidrogênio + 90\% de argônio) de $100 \mathrm{~mL} / \mathrm{min}$ a diferentes temperaturas $\left(700,800,900,1000\right.$ e $\left.1100{ }^{\circ} \mathrm{C}\right)$ com 1 hora de duração em cada isoterma. 
Um comportamento semelhante das curvas de perda de massa da Figura 34 é observado, as curvas obtidas nas isotermas de 700 e $800{ }^{\circ} \mathrm{C}$ possuem perdas de massas próximas e as perdas de massas das curvas obtidas em 900,1000 e $1100{ }^{\circ} \mathrm{C}$ são próximas entre si e maiores do que as perdas de massas das curvas de 700 e $800^{\circ} \mathrm{C}$.

Outro comportamento que pode ser observado na Figura 34 e que na Figura 33 não apareceu, foi a mudança de inclinação da curva de perda de massa. Essa diminuição da inclinação indica uma diminuição da taxa de perda de massa o que indica uma desaceleração da reação de redução. Essa mudança de inclinação se destaca nas curvas das isotermas de 900, $1000 \mathrm{e}$ $1100{ }^{\circ} \mathrm{C}$. A mudança de inclinação ocorreu também nos ensaios realizados com fluxos de 150 e $200 \mathrm{~mL} / \mathrm{min}$ essa mudança de inclinação ocorreu em torno de $9 \%$ de perda de massa das amostras ensaiadas.

As perdas de massa das amostras ensaiadas com fluxo de $150 \mathrm{~mL}$, foram maiores que as perdas de massas das amostras ensaiadas com fluxos de 50 e $100 \mathrm{~mL}$ comparando as mesmas temperaturas.

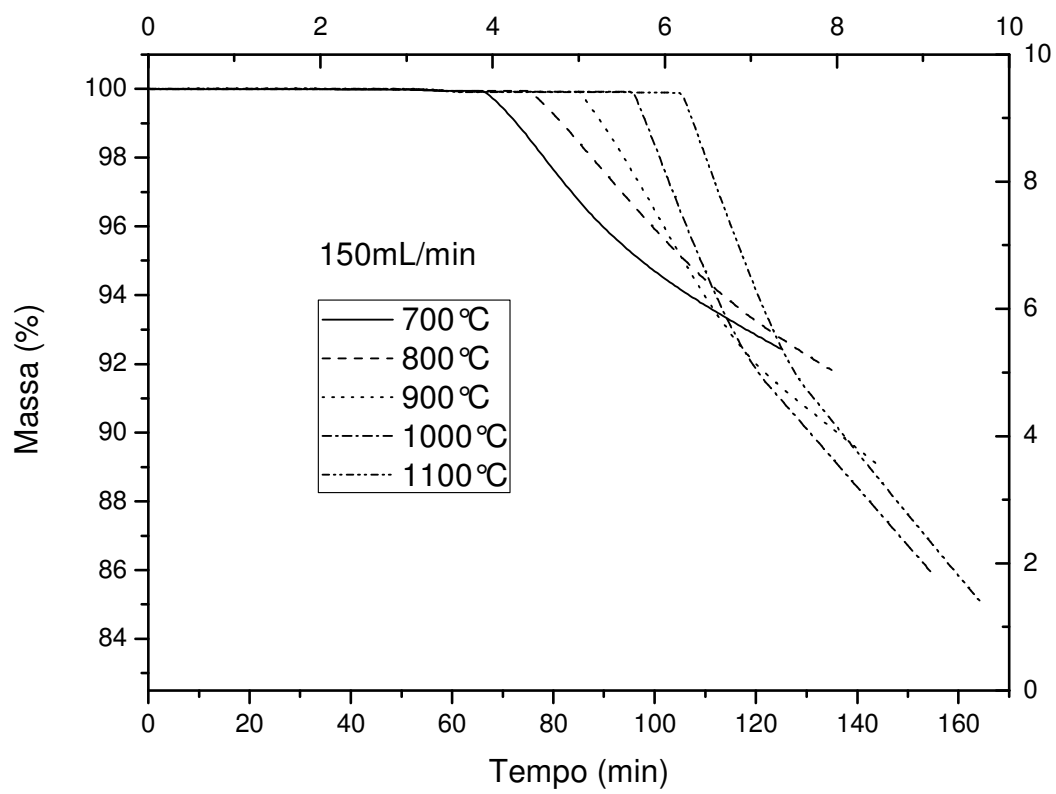

Figura 35: Massa versus tempo para pelota de redução direta ensaiada com fluxo de gás redutor (10\% de hidrogênio + 90\% de argônio) de $150 \mathrm{~mL} / \mathrm{min}$ a diferentes temperaturas $\left(700,800,900,1000\right.$ e $\left.1100{ }^{\circ} \mathrm{C}\right)$ com 1 hora de duração em cada isoterma. 


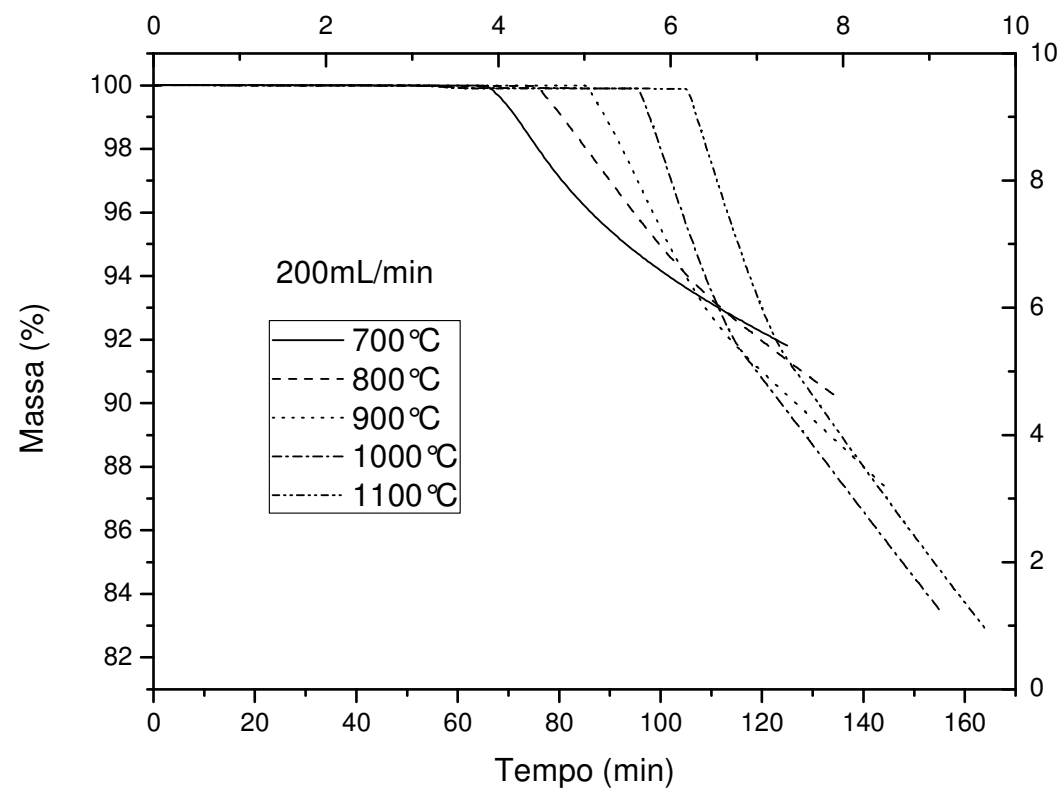

Figura 36: Massa versus tempo para pelota de redução direta ensaiada com fluxo de gás redutor ( $10 \%$ de hidrogênio $+90 \%$ de argônio) de $200 \mathrm{~mL} / \mathrm{min}$ a diferentes temperaturas $\left(700,800,900,1000\right.$ e $\left.1100{ }^{\circ} \mathrm{C}\right)$ com 1 hora de duração em cada isoterma.

A partir da análise e comparação das curvas de TG, nota-se um comportamento semelhante nos fluxos de 50, 100, 150 e $200 \mathrm{~mL}$. As perdas de massa nas isotermas de 700 e $800{ }^{\circ} \mathrm{C}$ são próximas e se diferem das perdas de massa nas isotermas de 900, 1000 e $1100{ }^{\circ} \mathrm{C}$, estas apresentam perdas de massa próximas e maiores do que as perdas de massa nas isotermas de 700 e $800^{\circ} \mathrm{C}$.

Outro comportamento observado é que quanto maior foi a temperatura da isoterma, maior foi a perda de massa.

Comparando as perdas de massas em uma mesma temperatura para os diferentes fluxos utilizados, notou-se que o fluxo de $200 \mathrm{~mL} / \mathrm{min}$ de gás redutor foi o que possibilitou as maiores perdas de massa nas temperaturas estudadas.

A desaceleração da redução ocorrida em torno de $9 \%$ da perda de massa, pode estar associada ao fim da redução da hematita para magnetita, o que equivale a uma perda de massa em torno de $10 \%$, referente ao oxigênio retirado da hematita [77]. 


\section{Efeito da temperatura}

A temperatura exerce influência na taxa de redução global das pelotas. O aumento da temperatura causa o aumento da taxa de redução. Os resultados indicam que no intervalo de temperatura entre $800{ }^{\circ} \mathrm{C}$ e $900{ }^{\circ} \mathrm{C}$ aparenta ser o mais indicado para a redução de pelotas de minério de ferro.

A partir dos resultados do efeito da temperatura sobre a taxa de redução e da redução final alcançada é que foi estabelecida a temperatura de $850{ }^{\circ} \mathrm{C}$ para os ensaios de redução a serem realizados no forno com as pelotas dos pellets feed A, B e C.

\section{Efeito do fluxo de gás redutor}

Conforme foi observado o fluxo de gás redutor influência na taxa de redução das pelotas. Notou-se que o fluxo de $200 \mathrm{~mL} / \mathrm{min}$ alcançou a maior perda de massa para um mesmo intervalo de tempo.

Com o conhecimento dos resultados do efeito da temperatura e do fluxo de gás, é que foi estabelecido o fluxo de $200 \mathrm{~mL} / \mathrm{min}$ de gás redutor a ser utilizado nos ensaios na termobalança com as pelotas dos pellets feed A, B e C.

\subsection{Caracterizações dos pellets feed A, B e C}

A caracterização dos minérios visou a busca de informações e conhecimentos de forma global e detalhada, dos pellets feed A, B e C. A caracterização foi realizada buscando resultados que determinassem as principais propriedades dos pellets feed.

As caracterizações realizadas foram: identificação e quantificação das fases presentes, distribuição de tamanhos de partículas, área de superfície específica, densidade aparente e morfologia das partículas.

\subsubsection{Difração de raios-X}


As Figura 37, 42, 43 e 44 mostram os difratogramas dos pellets feed A, $\mathrm{B}, \mathrm{C}$ e da pelota para redução direta respectivamente.

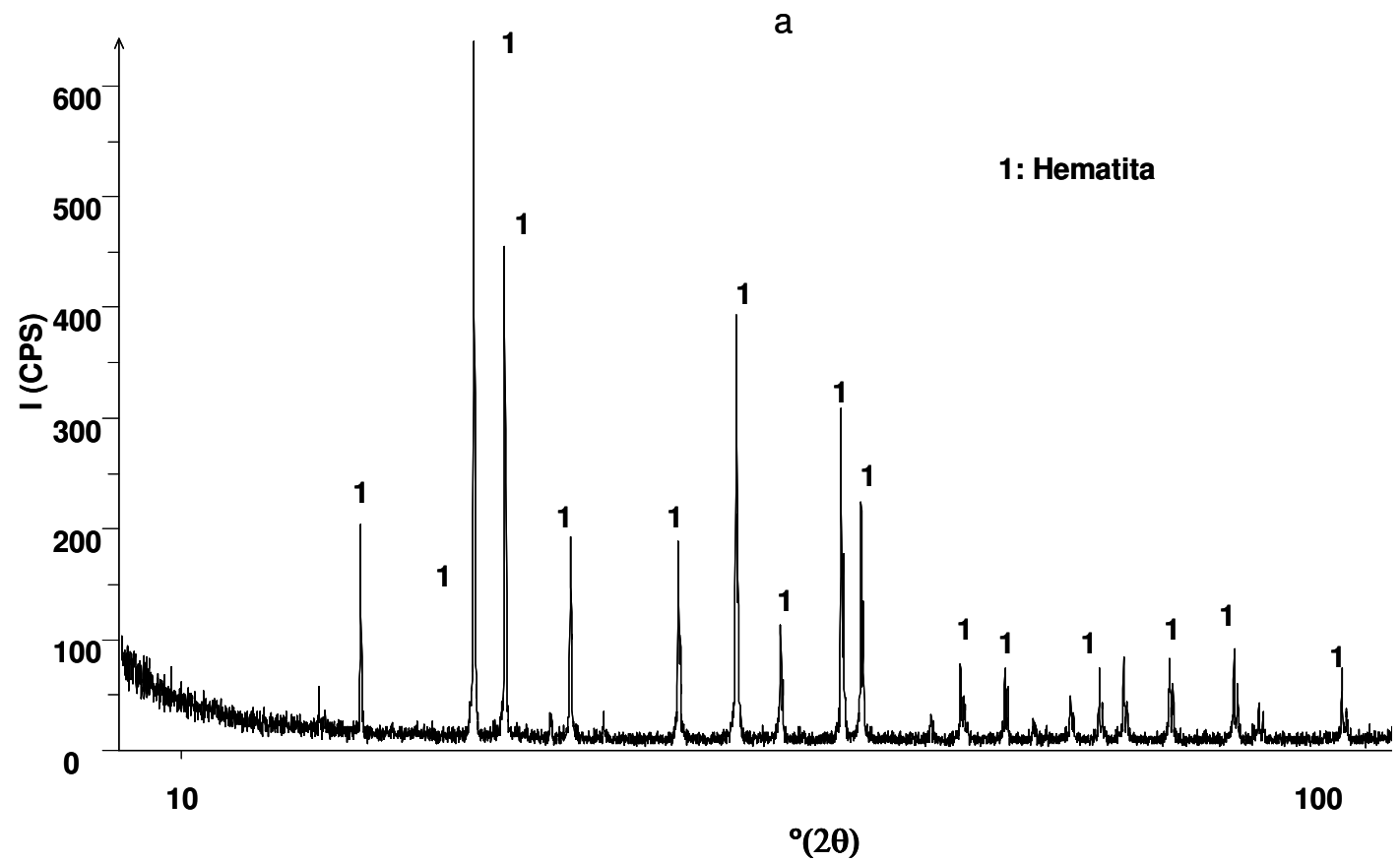

Figura 37: Difratograma do pellet feed A

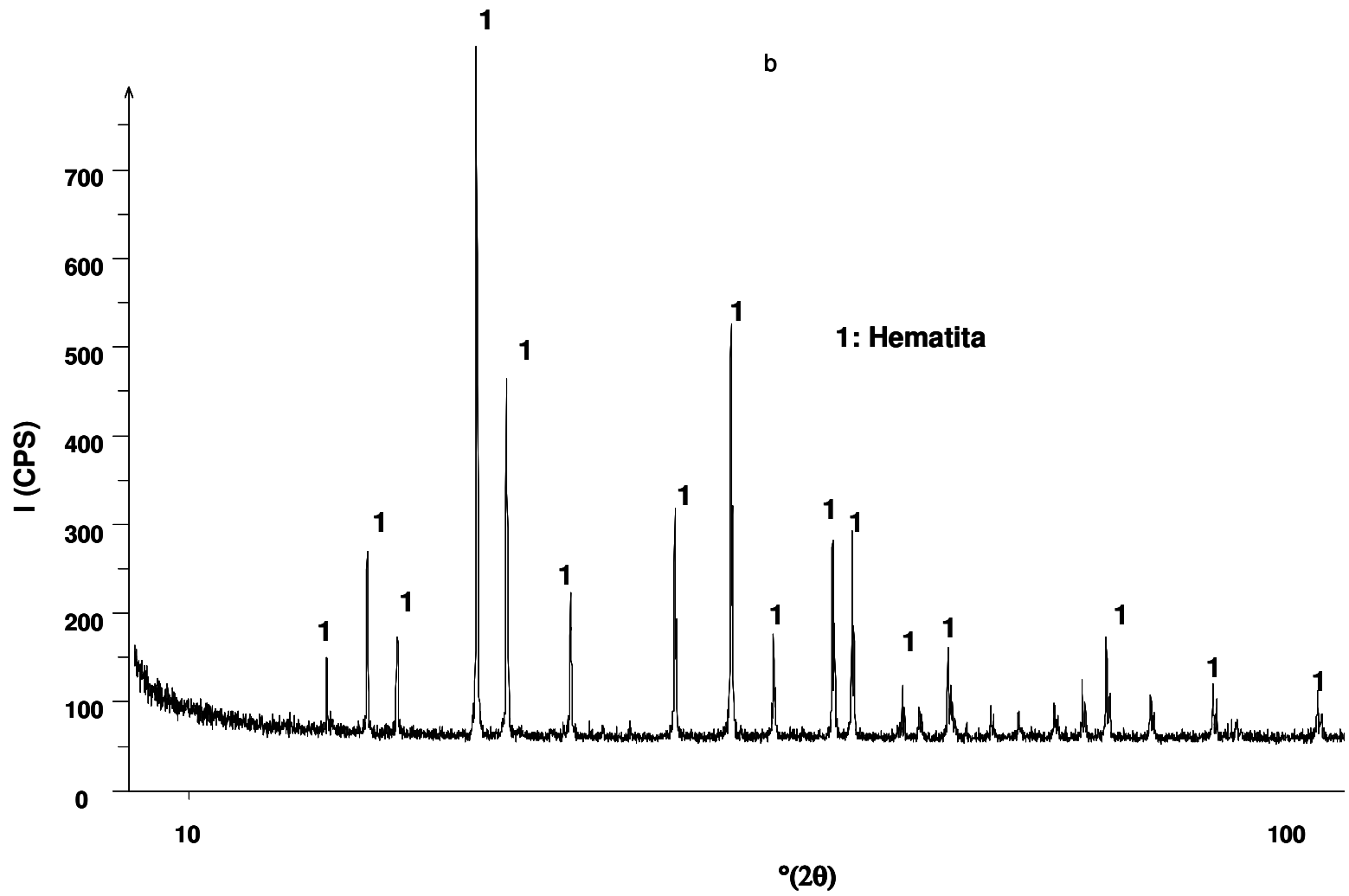

Figura 38: Difratograma do pellet feed $\mathrm{B}$. 


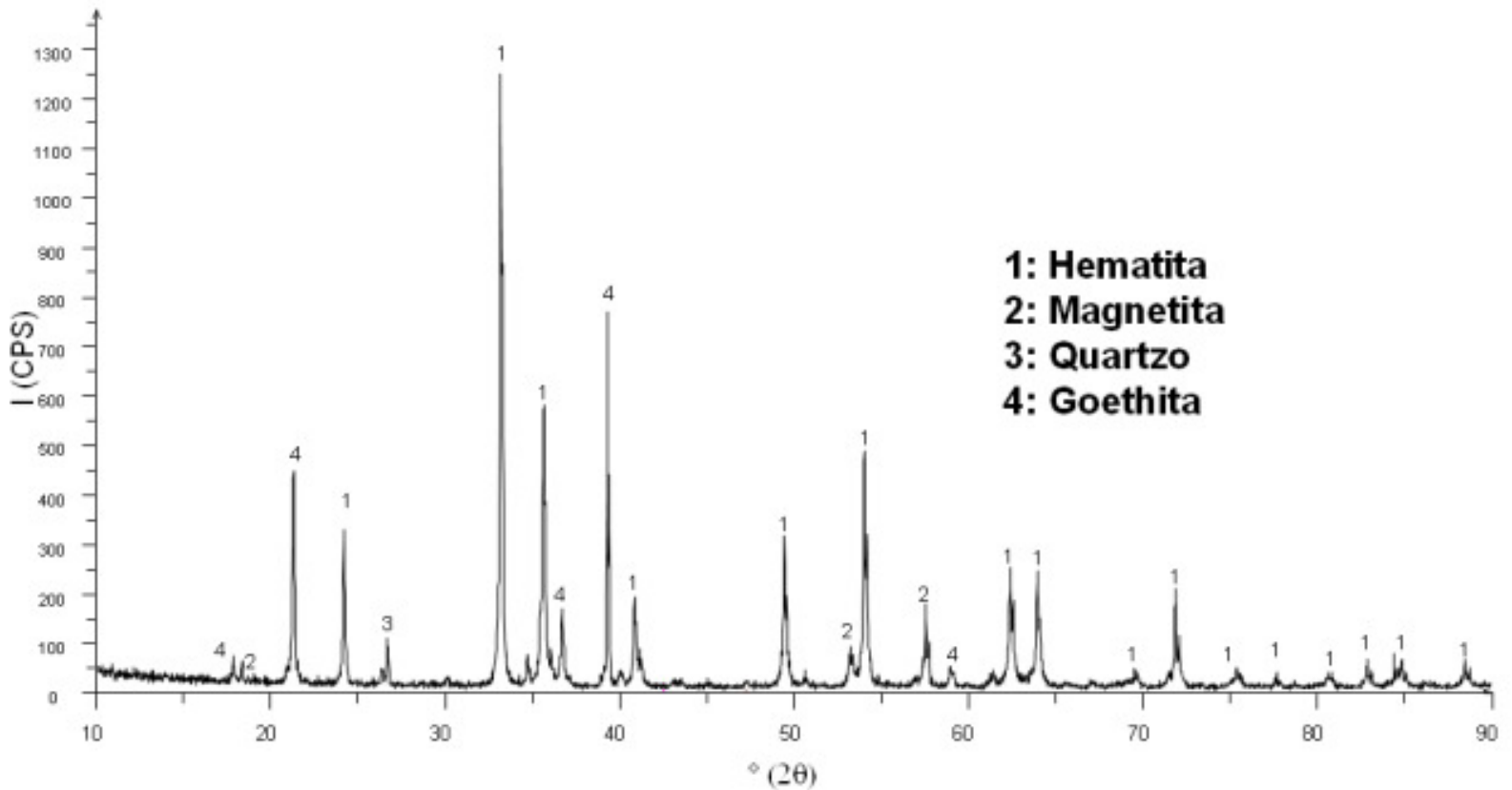

Figura 39: Difratograma do pellet feed C.

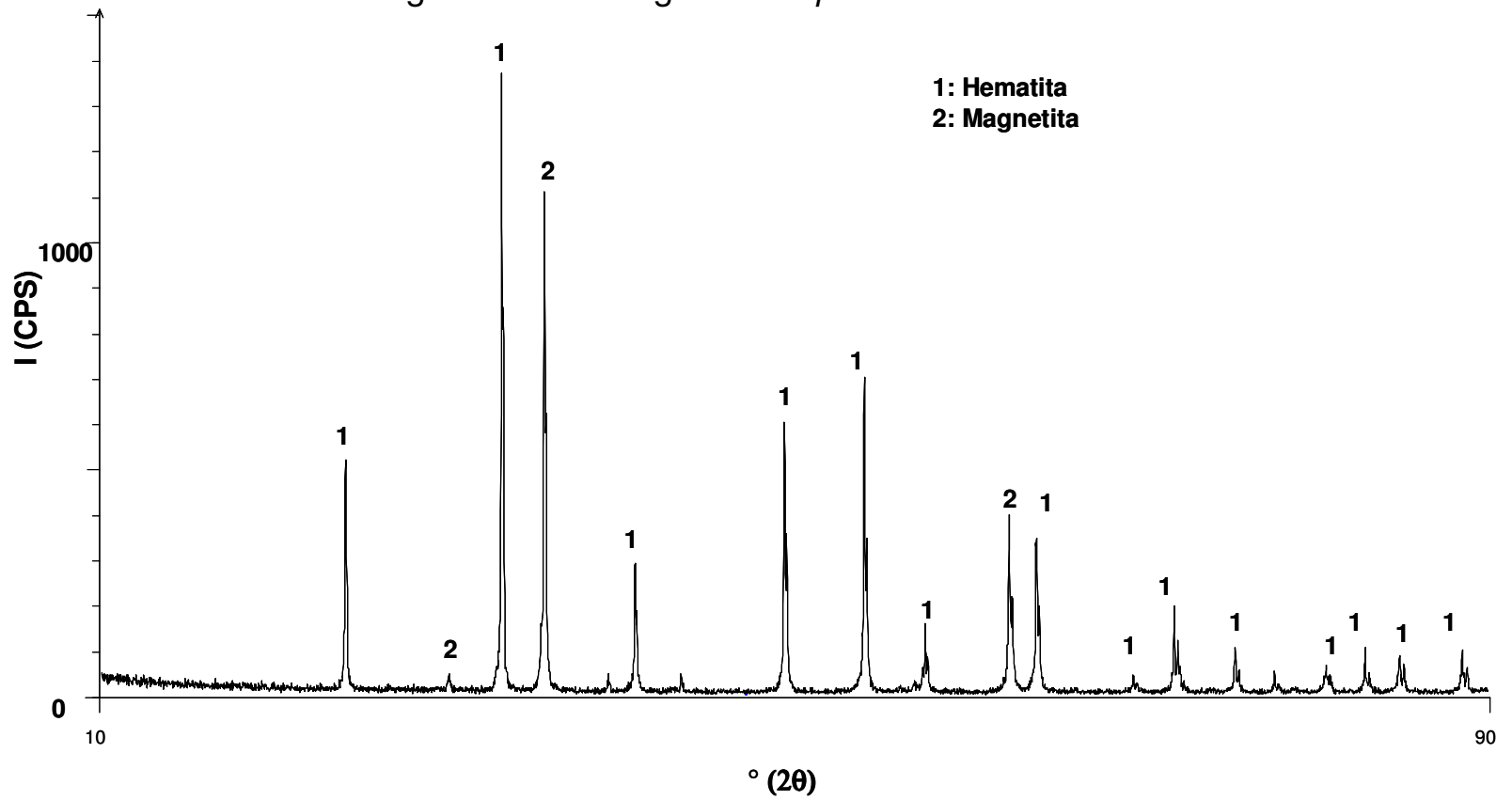

Figura 40: Difratograma da pelota para redução direta

A fase identificada nos difratogramas dos pellets feed A e B é a hematita, já nos difratogramas do pellet feed $\mathrm{C}$ aparecem picos referentes à hematita, magnetita, quartzo e goethita, e nas pelotas para redução direta são observados picos de hematita e magnetita.

É observado que todas as amostras analisadas são constituídas principalmente por hematita. Sendo que no pellet feed C apareceu as fases magnetita, goethita e o quartzo. 
Em seguida, foi realizada a quantificação de fases realizada pelo método de Rietveld, onde os resultados são apresentados na Tabela 7.

Tabela 7: Quantificação das fases (\% massa) presentes nas pelotas para redução direta e nos pellets feed A, B e C obtida pelo método de Rietveld.

\begin{tabular}{|c|c|c|c|c|}
\hline Fases & $\begin{array}{c}\text { Pellet feed A } \\
\text { (\% em massa) }\end{array}$ & $\begin{array}{c}\text { Pellet feed B } \\
\text { (\% em massa) }\end{array}$ & $\begin{array}{c}\text { Pellet feed C } \\
\text { (\% em massa) }\end{array}$ & $\begin{array}{c}\text { Pelota para } \\
\text { redução direta } \\
\text { (\% em massa) }\end{array}$ \\
\hline Hematita & 100 & 100 & 88,5 & 93,3 \\
\hline Magnetita & --- & --- & 6,2 & 6,7 \\
\hline Goethita & --- & --- & 4,2 & \\
\hline Quartzo & --- & --- & 1,1 & \\
\hline
\end{tabular}

Todos os pellets feed analisados são hematíticos. Dentro dos limites da técnica, os pellets feed A e B apresentam a mesma composição mineralógica.

A partir dos dados sobre a composição química fornecida pelas empresas que doaram os minérios e dos resultados calculados pelo método Rietiveld, foram realizados cálculos estequiométricos para verificar as possíveis diferenças entre os resultados. A Tabela 8 mostra os resultados dos cálculos estequiométricos realizados.

Tabela 8: Resultados dos cálculos estequiométricos calculados a partir da composição química e análise Rietveld.

\begin{tabular}{|c|c|c|c|c|}
\hline Fases & $\begin{array}{c}\text { Pellet feed A } \\
\text { (\% em massa) }\end{array}$ & $\begin{array}{c}\text { Pellet feed B } \\
\text { (\% em massa) }\end{array}$ & $\begin{array}{c}\text { Pellet feed C } \\
\text { (\% em massa) }\end{array}$ & $\begin{array}{c}\text { Pelota para } \\
\text { redução direta } \\
\text { (\% em massa) }\end{array}$ \\
\hline $\mathbf{F e}_{\text {(total) }}$ & 66,9 & 67,2 & 69,05 & 70,16 \\
\hline Hematita & 95,57 & 96 & --- & --- \\
\hline
\end{tabular}

Para os pellets feed A e B foram calculados a porcentagem de hematita a partir da quantidade de ferro total fornecido pela análise química. A quantidade hematita encontrada foram $95,57 \%$ e $96 \%$ para os pellets feed A e $B$ respectivamente. Estes valores calculados diferem dos valores encontrados pelo método Rietveld que indicaram 100\% de hematita. As diferenças entre estes valores podem ser explicadas pelos limites de detecção e precisão das diferentes técnicas utilizadas. A diferença entre os valores, em torno de $4 \%$ não é significativa para os cálculos de cinética.

Para o pellet feed $\mathrm{C}$ e a pelota de redução direta, foram realizados os cálculos da quantidade de ferro total a partir dos dados da análise Rietveld, os 
valores encontrados foram $69,05 \%$ e $70,16 \%$ respectivamente. Estes valores calculados, foram comparados com os valores (67,11\% (pellet feed $\mathrm{C}$ ) e $67,8 \%$ (pelota para redução direta)) do ferro total fornecido com a composição química dos minérios. Nota-se que os valores são levemente diferentes, em torno de $1.94 \%$ e 2,36\% para o pellet feed C e a pelota para redução direta respectivamente. As diferenças entre estes valores podem ser explicadas pelos limites de detecção e precisão das diferentes técnicas utilizadas. A diferença entre os valores, em torno de 1,94\% não é significativa para os cálculos de cinética. 


\subsubsection{Distribuição granulométrica}

A Figura 41 mostra as curvas de distribuição granulométrica dos pellets feed A, B e C.

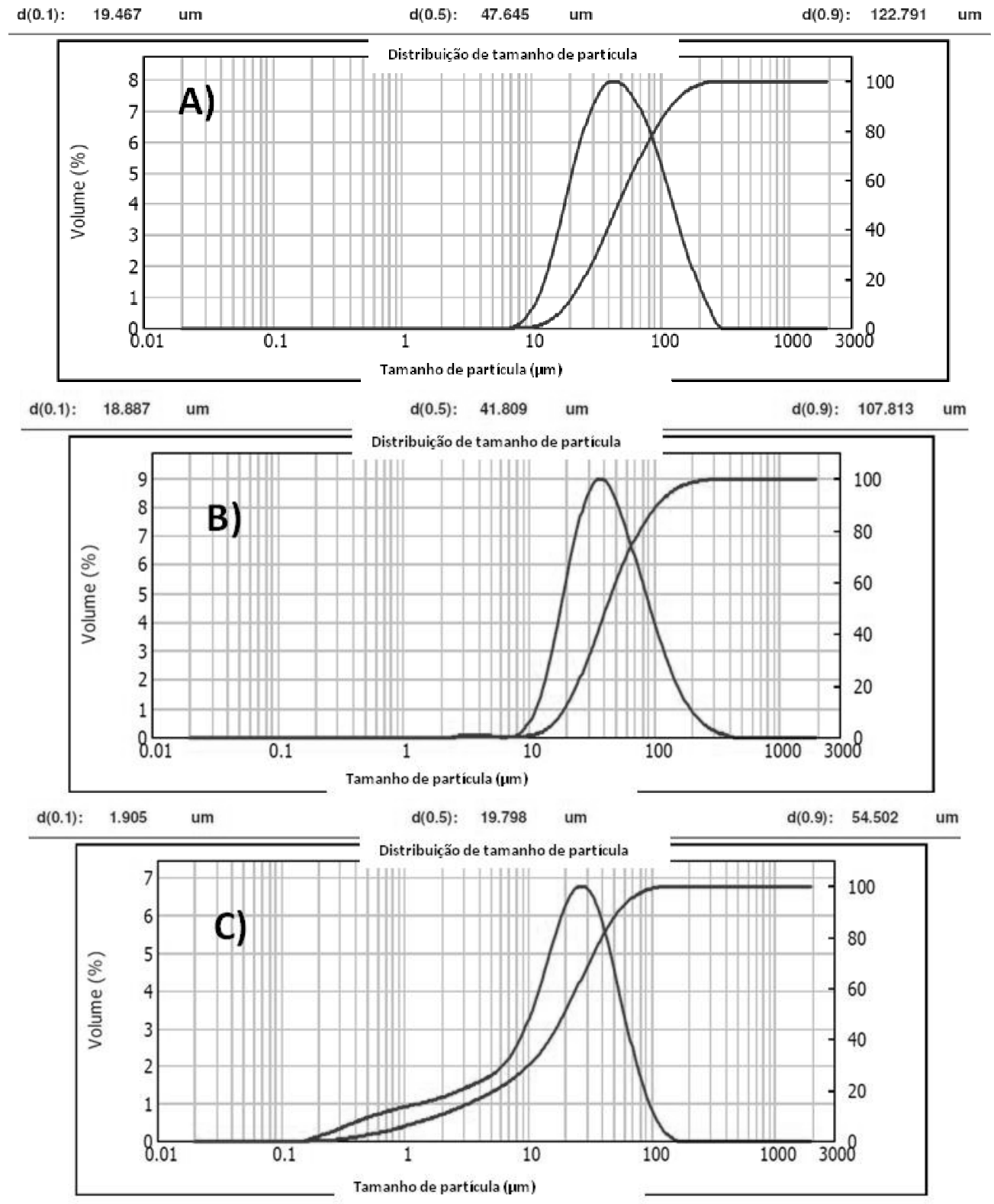

Figura 41: Distribuição granulométrica dos minérios $A, B$ e $C$ realizada por difração a laser.

Nota-se que as curvas de distribuição de partículas dos três pellets feed apresentadas na Figura 41 possuem alguma semelhança. Apesar de serem de pellets feed diferentes. 
A Tabela 9 mostra um resumo dos principais parâmetros obtidos a partir das curvas de distribuição granulométrica apresentadas na Figura 41 obtidas por difração a laser.

Tabela 9: Valores da Distribuição do tamanho de partículas dos pellets feed A, B e C obtidos por difração a laser.

\begin{tabular}{|l|c|c|c|}
\hline & Pellet feed A & Pellet feed B & Pellet feed C \\
\hline$D_{10}(\mu \mathrm{m})$ & 19,467 & 18,887 & 1,905 \\
\hline$D_{50}(\mu \mathrm{m})$ & 47,645 & 41,809 & 19,798 \\
\hline$D_{90}(\mu \mathrm{m})$ & 122,791 & 107,813 & 54,502 \\
\hline
\end{tabular}

Os parâmetros $D_{10}, D_{50}$ e $D_{90}$ indicam que $10 \%, 50 \%$ e $90 \%$ das partículas respectivamente estão abaixo do tamanho indicado por estes valores. Os parâmetros $D_{10}, D_{50}$ e $D_{90}$ do pellet feed $C$ são menores que os mesmos parâmetros dos pellets feed A e B. Estes resultados indicam que o pellet feed $\mathrm{C}$ é mais fino que os pellets feed A e B. As granulometrias estão dentro da faixa recomendada para um pellet feed [21].

\subsection{3 Área de superfície específica}

Uma variável de controle importante na produção de pellet feed e no processo de redução é a superfície específica média da população de partículas do concentrado de minério de ferro. Quanto maior a superfície específica média, maior a energia superficial da população de partículas, favorecendo o processo de pelotização e de redução, independendo do método.

A Tabela 10 mostra os resultados sobre a área de superfície específica, volume de poros e diâmetro médio de poros calculados pelo método BET. 
Tabela 10: Resultados dos parâmetros avaliados pelo ensaio de adsorção de nitrogênio - método B.E.T. dos pellet feed A, B e C.

\begin{tabular}{|c|c|c|c|}
\hline Amostra & $\begin{array}{c}\text { Volume de } \\
\text { poros } \\
\left(\mathbf{c m}^{\mathbf{3}} / \mathbf{g}\right) \mathbf{1} \mathbf{1 0}^{-3}\end{array}$ & $\begin{array}{c}\text { Diâmetro } \\
\text { médio de } \\
\text { poros }(\mathbf{A})\end{array}$ & $\begin{array}{c}\text { Superfície } \\
\text { específica } \\
\mathbf{B . E . T} \\
\left(\mathbf{m}^{2} / \mathbf{g}\right)\end{array}$ \\
\hline A & 1,98 & 36,65 & 2,16 \\
\hline B & 2,03 & 35,07 & 2,23 \\
\hline C & 16,22 & 42,44 & 15,29 \\
\hline
\end{tabular}

Nota-se da Tabela 10, através dos parâmetros avaliados, que a área de superfície específica varia entre $2,16 \mathrm{~m}^{2} / \mathrm{g}$ a $15,29 \mathrm{~m}^{2} / \mathrm{g}$ e que o volume de poros variou entre $1,98 \times 10^{-3} \mathrm{~cm}^{3} / \mathrm{g}$ a $16,22 \times 10^{-3} \mathrm{~cm}^{3} / \mathrm{g}$. Em uma análise comparativa, o pellet feed $\mathrm{C}$ apresenta um maior volume de poros e uma área de superfície específica maior que os pellets feed A e B.

Nota-se dos resultados que quanto maior o volume de poros maior é o valor da área de superfície específica.

Relacionando os resultados de área de superfície específica e de distribuição de tamanho de partículas, nota-se que o pellet feed A é o que apresenta maior tamanho médio de partículas e, consequentemente, uma menor área de superfície específica que os pellets feed $\mathrm{B}$ e $\mathrm{C}$. O pellet feed $\mathrm{C}$ possui um tamanho médio de partículas menor e consequentemente uma maior área de superfície específica do que os pellets feed A e B.

\subsubsection{Densidade aparente}

A Tabela 11 mostra os resultados das densidades aparentes dos pellets feed A, B e C.

Tabela 11: Densidade aparente dos pellets feed A, B e C.

\begin{tabular}{|c|c|c|c|}
\hline & Pellet feed A & Pellet feed B & Pellet feed C \\
\hline Densidade $\left(\mathbf{g} / \mathbf{c m}^{3}\right)$ & 5,19 & 5,59 & 4,58 \\
\hline
\end{tabular}

Nota-se que os pellets feed possuem densidades próximas. Essa diferença nas densidades pode ser atribuída à porosidade. $\mathrm{O}$ pellet feed $\mathrm{C}$ possui a menor densidade em com comparação aos pellets feed $\mathrm{A}$ e B. 
Os resultados de densidade corroboram com os resultados de volume de poros. Ou seja, o pellet feed $\mathrm{C}$ é o que possui maior volume de poros e, consequentemente menor densidade aparente e maior área de superfície específica quando comparado com os pellets feed A e B.

\subsubsection{Densidade das pelotas}

A Tabela 12 mostra os resultados de densidade obtidos e a porosidade total para cada um dos tipos de pelotas estudadas. A pelota $B$ foi a que apresentou maior porosidade total, seguida da pelota $A$ e depois a pelota $C$. As pelotas A e B apresentaram porosidade bem parecida podendo ser atribuída essa semelhança ao tipo de pellet feed que deu origem a estes dois tipos de pelota.

Tabela 12: Resultados de densidade volumétrica e teórica, e porosidade total para cada um dos tipos de pelotas estudadas, dos pellets feed A, B e C.

\begin{tabular}{|c|c|c|c|}
\hline $\begin{array}{c}\text { Pelota } \\
(\text { pellet feed })\end{array}$ & $\begin{array}{c}\text { Densidade } \\
\text { aparente } \\
\text { Das pelotas } \\
\left(\rho_{P}\right)\left(\mathbf{g} / \mathbf{c m}^{3}\right)\end{array}$ & $\begin{array}{c}\text { Densidade pellet } \\
\text { feed }\left(\rho_{P F}\right) \\
\left(\mathbf{g} / \mathbf{c m}^{3}\right)\end{array}$ & $\begin{array}{c}\text { Porosidade total } \\
\left(\mathrm{V}_{\mathrm{P}}\right)(\%)\end{array}$ \\
\hline A & 3,19 & 5,19 & 38,54 \\
\hline B & 3,15 & 5,59 & 43,64 \\
\hline C & 3,69 & 4,58 & 19,43 \\
\hline
\end{tabular}

\subsubsection{Caracterização da morfologia}

Devido às diferentes condições de metamorfismo, tectonismo e intemperismo a que foram sujeitos, ou, mesmo, em virtude de sua gênese, os minérios brasileiros apresentam estruturas internas muito variadas [113]. Com isso, diferentes constituintes mineralógicos, tamanho e morfologia dos cristais, tamanho e morfologia dos poros, porosidade, forma e superfícies das partículas, aparecem nos minérios [113]. 
As imagens do pellets feed A mostram que na fração retida na peneira com abertura de $0,149 \mathrm{~mm}$ as partículas possuem geometria irregular. As partículas das frações retidas nas peneiras de $0,088 \mathrm{~mm}$ e $0,074 \mathrm{~mm}$ possuem formas lamelares e com geometria irregular, sendo que nestas duas frações a quantidade de partículas lamelares é maior.

Nos pellets feed A e B as partículas lamelares aparecem em maior número quando comparados com o pellet feed $\mathrm{C}$. Foi possível verificar que as partículas menores tendem a se aglomerar sobre as partículas maiores e rugosas. Deste modo, as partículas maiores atuam como nucleantes e as menores como aderentes.

Conforme Frick [113], as morfologias observadas podem ser classificadas em hematita granular e hematita lamelar. Os pellets feed A e B possuem uma maior quantidade de hematita lamelar quando comparado com $\mathrm{o}$ pellet feed $\mathrm{C}$. Sendo que os dados do volume de poros discutidos na seção sobre área de superfície específica, indicam que as partículas do pellet feed $\mathrm{C}$ são porosas indicando que estas partículas poderiam ser classificadas como martita porosa. A martita é uma hematita conhecida como pseudomórfica a partir de transições sofridas pela magnetita [114].

Frick [113] comenta ainda que as partículas de hematita de forma lamelar têm pequena área por unidade de massa e superfície muito lisa. E que os núcleos formados por partículas lamelares possuem baixa capacidade de retenção de aderentes. Os resultados obtidos neste trabalho também são coerentes com estas observações. Pois os pellets feed A e B, possuem maior quantidade de partículas lamelares, e foi necessário adicionar aglomerante no processo de pelotização.

A Figura 42 mostra as imagens de elétrons retroespalhados das frações granulométricas do pellet feed A. As Figura 43 e Figura 44 mostram as imagens de elétrons retroespalhados e elétrons secundários das frações granulométricas dos pellets feed $\mathrm{B}$ e $\mathrm{C}$ respectivamente. 

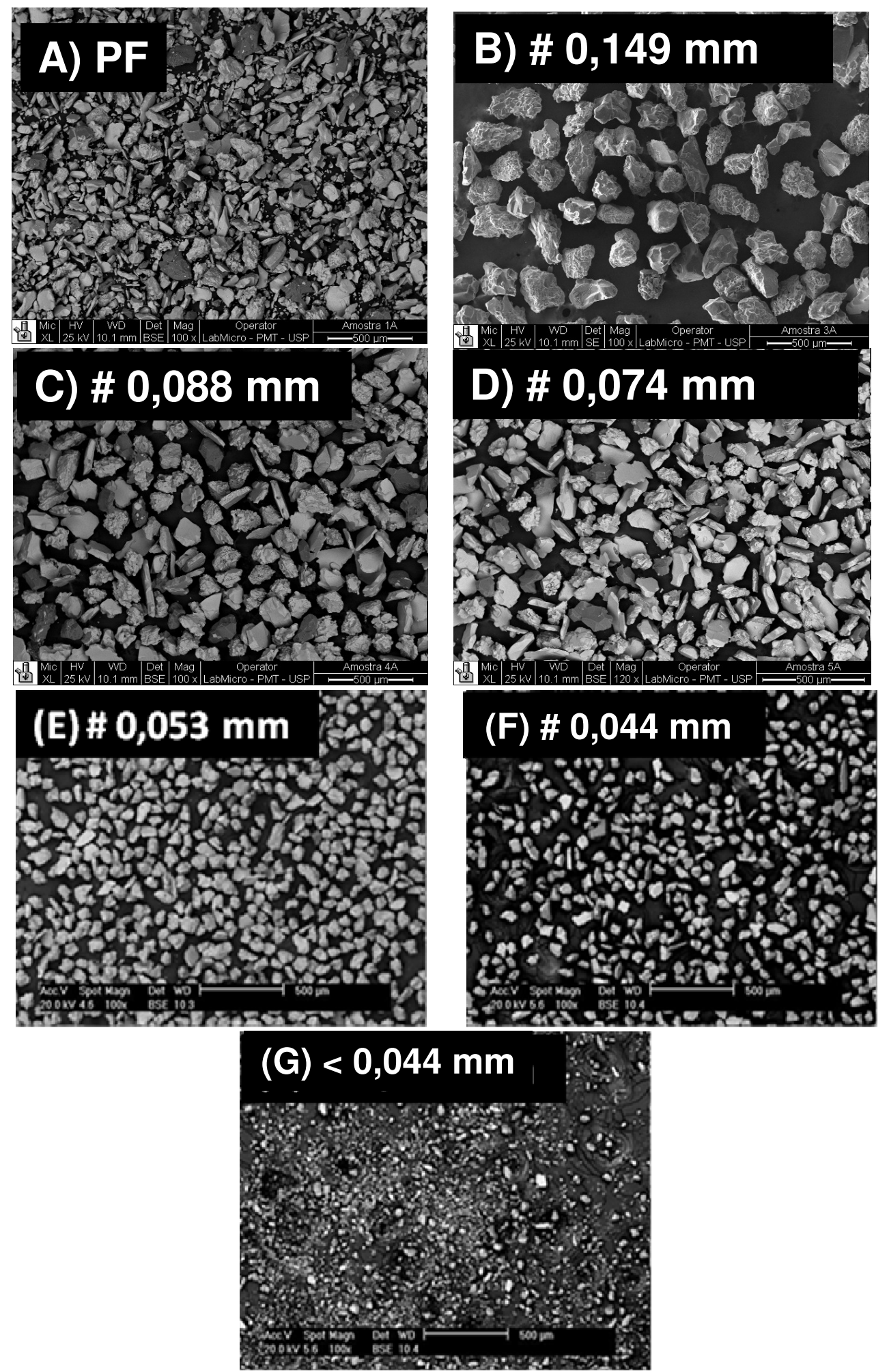

Figura 42: Imagens de elétrons retroespalhados do Pellet feed A. (A) pellet feed, (B) fração retida na peneira com abertura de $0,149 \mathrm{~mm},(\mathrm{C})$ passante pela peneira com abertura de $0,149 \mathrm{~mm}$ e retida na peneira abertura de $0,088 \mathrm{~mm}$, (D) passante pela peneira com abertura de $0,088 \mathrm{~mm}$ e retida na peneira com abertura de $0,074 \mathrm{~mm}$, (E) passante pela peneira com abertura de $0,074 \mathrm{~mm}$ e retida na peneira com abertura de $0,053 \mathrm{~mm}$, (F) passante pela peneira com abertura $0,0523 \mathrm{~mm} e$ retida na peneira com abertura de $0,044 \mathrm{~mm}$ e (G) FUNDO fração que passou pela peneira de 0,044 $\mathrm{mm}$. 

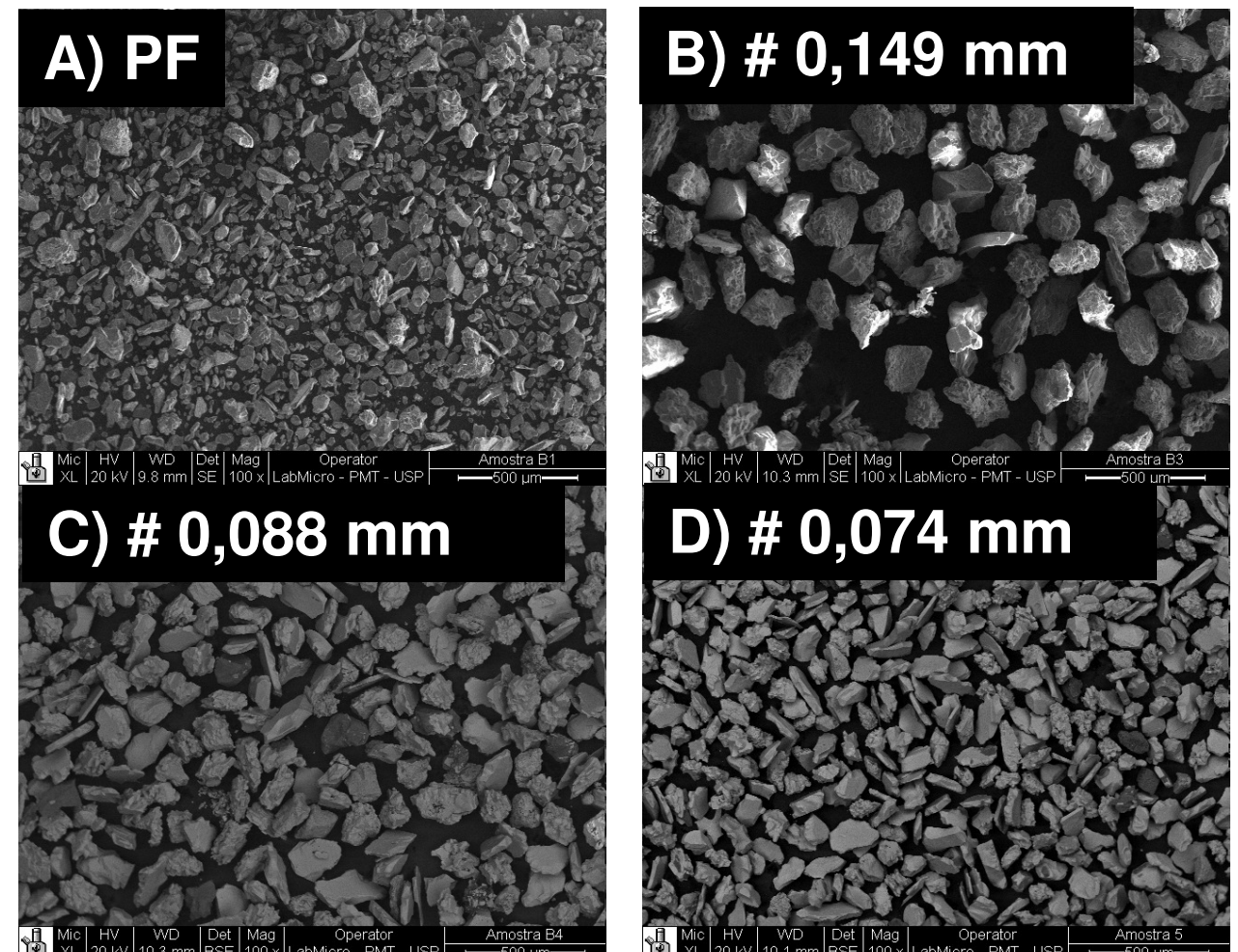

\section{E) \# 0,053 $\mathrm{mm}$}
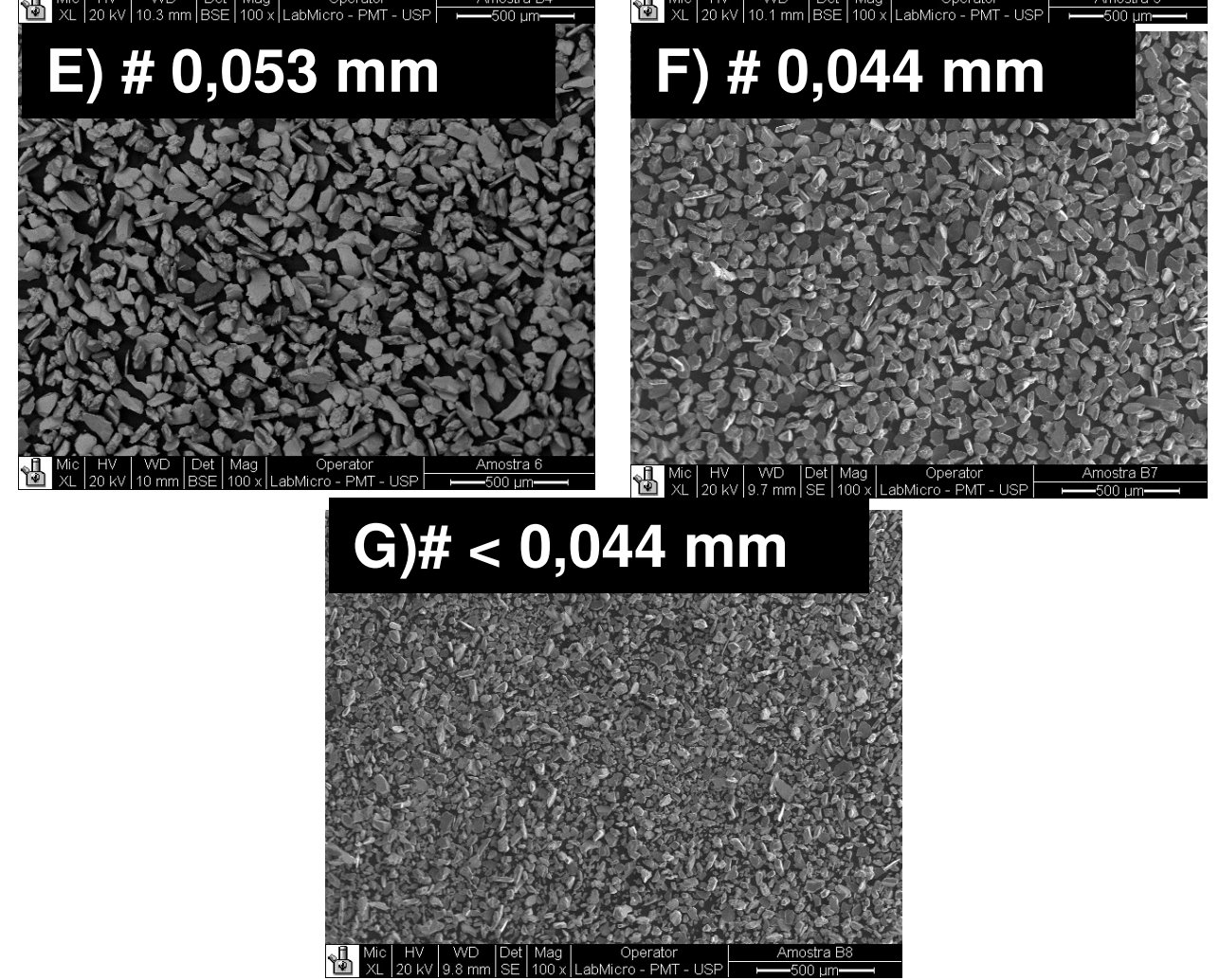

Figura 43: Imagens de elétrons retroespalhados do Pellet feed B. (A) pellet feed, (B) fração retida na peneira com abertura de $0,149 \mathrm{~mm},(\mathrm{C})$ passante pela peneira com abertura de $0,149 \mathrm{~mm}$ e retida na peneira abertura de $0,088 \mathrm{~mm}$, (D) passante pela peneira com abertura de $0,088 \mathrm{~mm}$ e retida na peneira com abertura de $0,074 \mathrm{~mm}$, (E) passante pela peneira com abertura de $0,074 \mathrm{~mm}$ e retida na peneira com abertura de $0,053 \mathrm{~mm}$, (F) passante pela peneira com abertura $0,0523 \mathrm{~mm} e$ retida na peneira com abertura de $0,044 \mathrm{~mm}$ e (G) FUNDO fração que passou pela peneira de $0,044 \mathrm{~mm}$. 

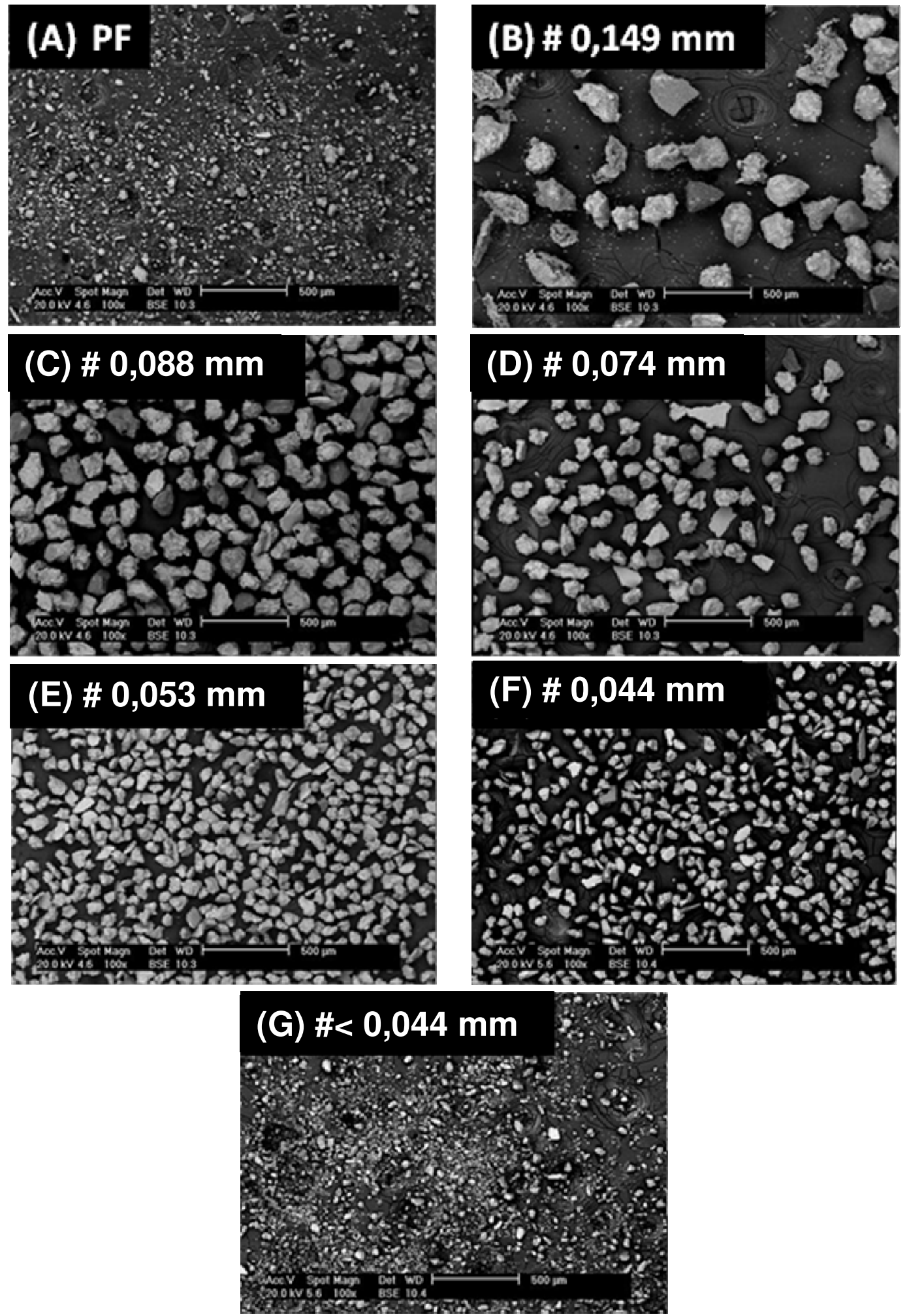

Figura 44: Imagens de elétrons retroespalhados do pellet feed C. (A) pellet feed, (B) fração retida na peneira com abertura de $0,149 \mathrm{~mm},(C)$ passante pela peneira com abertura de $0,149 \mathrm{~mm}$ e retida na peneira abertura de $0,088 \mathrm{~mm}$, (D) passante pela peneira com abertura de $0,088 \mathrm{~mm}$ e retida na peneira com abertura de $0,074 \mathrm{~mm}$, (E) passante pela peneira com abertura de $0,074 \mathrm{~mm}$ e retida na peneira com abertura de $0,053 \mathrm{~mm}$, (F) passante pela peneira com abertura $0,0523 \mathrm{~mm}$ e retida na peneira com abertura de 0,044 mm e (G) FUNDO fração que passou pela peneira de 0,044 mm. 


\subsection{Análise cinética}

São apresentados e descritos os resultados obtidos pelo método Jump e pelo método FSIA.

\subsubsection{Método Jump}

Os resultados da aplicação do método Jump com os dados obtidos por FSIA são descritos nesta seção. Conforme explicado anteriormente, o método Jump permite determinar energias de ativação de processos químicos ou de transporte sem que se conheça o mecanismo atuante. O método Jump se enquadra na categoria denominada como "model-free" encontrado na literatura $[43,44,47,64]$.

A reação sólido-gás envolve uma série de eventos dos quais, geralmente só um será o passo mais lento e, portanto, o passo controlador da velocidade [41]. Quando há a presença de eventos envolvendo transferência de massa, a cinética pode ser afetada, e as energias de ativação obtidas tendem a valores que são comuns em processos físicos e não em processos puramente químicos. A cinética realmente observada é, neste caso, chamada de cinética aparente ou efetiva, enquanto que a cinética que não é afetada por processos de difusão é chamada de cinética intrínseca. Portanto, os valores de energias de ativação calculadas neste trabalho são aparentes [41].

\section{Pelotas Pellet feed A / Redutor: (10\% de hidrogênio + $90 \%$ de argônio)}

A Figura 45 mostra o ciclo de temperaturas composta por patamares em função do tempo e a massa em função do tempo para a redução em atmosfera redutora ( $10 \%$ de hidrogênio $+90 \%$ de argônio) da pelota do pellet feed $\mathrm{A}$. 


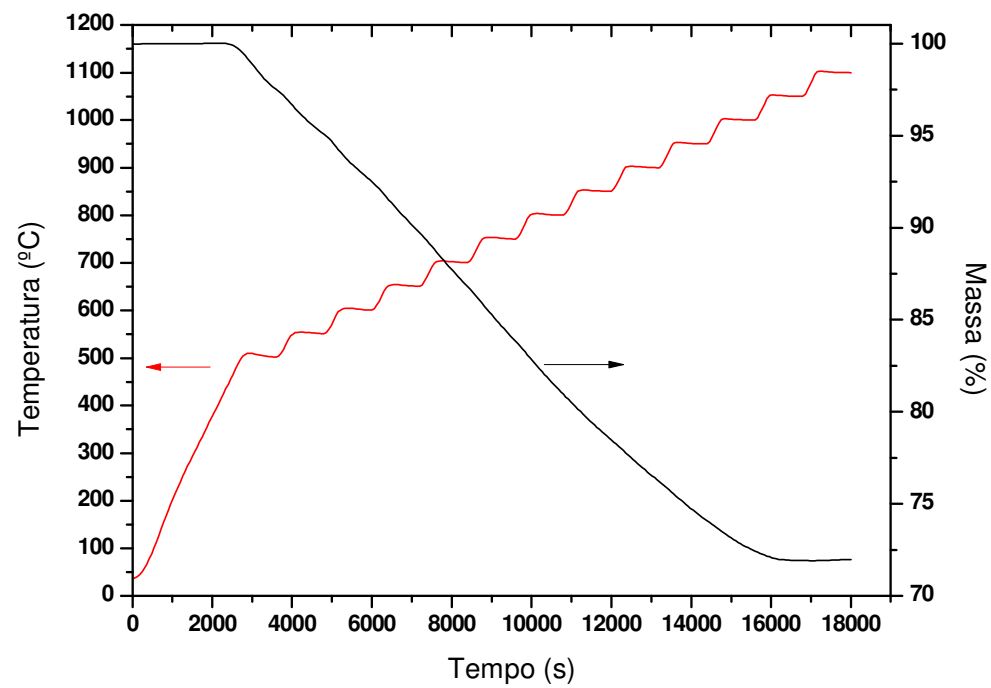

Figura 45: Massa em função do tempo e temperatura em função do tempo. Pelota do pellet feed $\mathrm{A}$ em atmosfera redutora (10\% de hidrogênio + $90 \%$ de argônio).

Nota-se pela curva da Figura 45, que a perda de massa inicia-se a partir do primeiro patamar a $500^{\circ} \mathrm{C}$, quando o fluxo de gás redutor é admitido. Observa-se também que quando ocorrem os dois últimos patamares, praticamente não há mais perda de massa. A perda de massa total atingiu $27,5 \%$.

A Figura 46 mostra a fração reagida em função do tempo (equação 12) da pelota do pellet feed A.

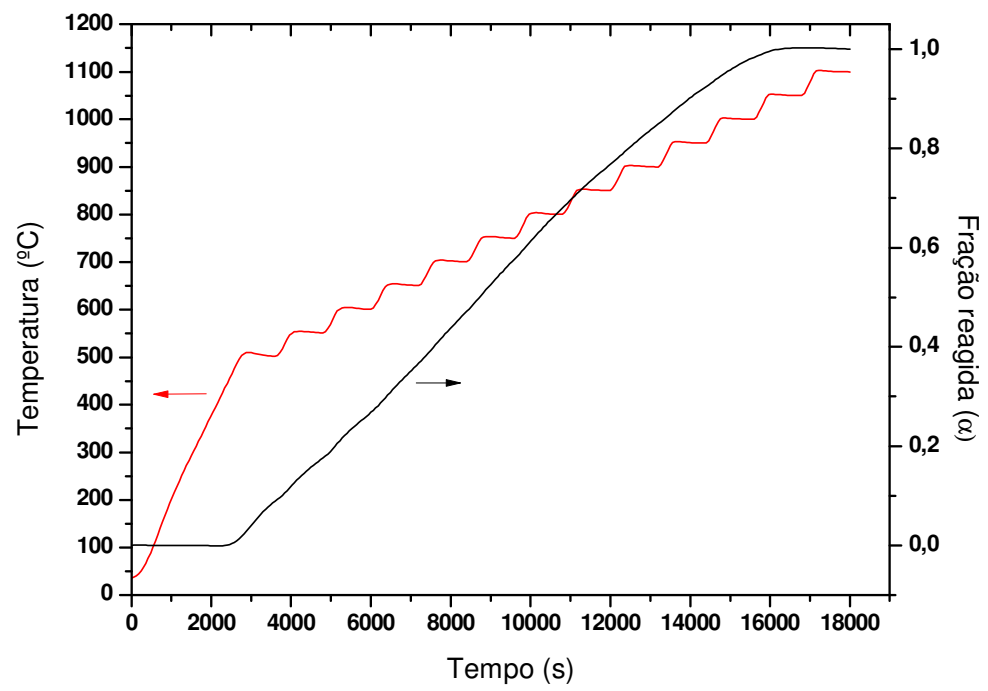

Figura 46: Fração reagida ( $\alpha$ ) em função do tempo. Pelota do pellet feed A em atmosfera redutora (10\% de hidrogênio + $90 \%$ de argônio). 
Observa-se na Figura 46, uma curva do tipo sigmoidal. Nota-se também que a curva torna-se horizontal no penúltimo patamar $\left(1050{ }^{\circ} \mathrm{C}\right)$, não ocorrendo mais reação a partir deste ponto.

Na Figura 47 observa-se a aplicação do método Jump para o cálculo da energia de ativação aparente da pelota do pellet feed $\mathrm{A}$ reduzido em atmosfera contendo $10 \%$ de hidrogênio e $90 \%$ de argônio.

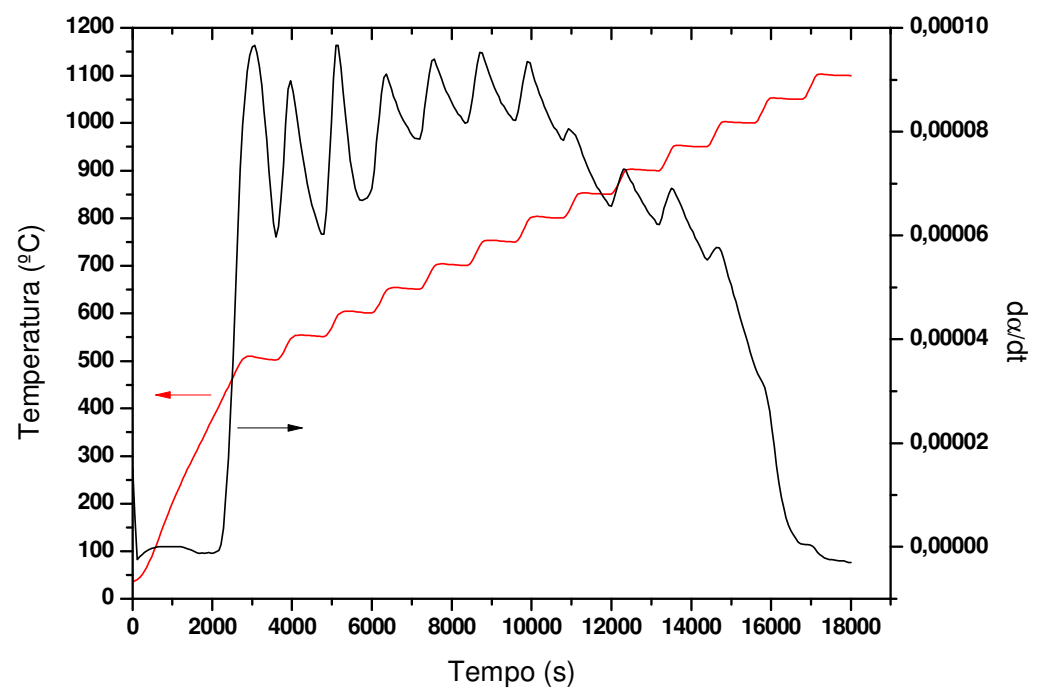

Figura 47: Aplicação do método Jump à análise FSIA. Pelota do pellet feed A em atmosfera redutora (10\% de hidrogênio + $90 \%$ de argônio).

Nota-se da Figura 47 que $d \alpha / d t$ apresenta variações entre o final de um patamar e o ínicio do patamar subseqüente. As variações são maiores no intervalo entre 2000 e $6000 \mathrm{~s}$, que se referem aos três primeiros picos. Outros picos são de menor amplitude, intercalados por pequenos ombros.

A Tabela 13 mostra os valores das variáveis e da energia de ativação aparente obtidas pelo método Jump aplicada nas condições mostradas na Figura 47. 
Tabela 13: Energias de ativação aparentes calculadas através do método Jump. Pelota do pellet feed A em atmosfera redutora ( $10 \%$ de hidrogênio $+90 \%$ de argônio).

\begin{tabular}{|c|c|c|c|c|c|c|c|}
\hline Etapa & $\left(\frac{d \alpha}{d t}\right)_{1}$ & $\left(\frac{d \alpha}{d t}\right)_{2}$ & $T_{1}(K)$ & $T_{2}(K)$ & $\ln \left[(d \alpha / d t)_{1} /(d \alpha / d t)_{2}\right.$ & $\frac{1}{T_{2}}-\frac{1}{T_{1}}$ & Ea (kJ/mol) \\
\hline 1 & $6,17 \mathrm{E}-05$ & $8,78 \mathrm{E}-05$ & 776,69 & 823,7 & $-3,52 \mathrm{E}-01$ & $-7,35 \mathrm{E}-05$ & 39,82 \\
\hline 2 & $6,03 \mathrm{E}-05$ & $9,23 \mathrm{E}-05$ & 824,1 & 874,42 & $-0,42657$ & $-6,98 \mathrm{E}-05$ & 50,79 \\
\hline 3 & $6,91 \mathrm{E}-05$ & $8,99 \mathrm{E}-05$ & 873,87 & 924,87 & $-0,26413$ & $-6,31 \mathrm{E}-05$ & 34,80 \\
\hline 4 & $7,86 \mathrm{E}-05$ & $9,40 \mathrm{E}-05$ & 923,73 & 972,08 & $-0,17961$ & $-5,38 \mathrm{E}-05$ & 27,73 \\
\hline 5 & $8,19 \mathrm{E}-05$ & $9,52 \mathrm{E}-05$ & 973,62 & 1022,62 & $-0,15074$ & $-4,92 \mathrm{E}-05$ & 25,47 \\
\hline 6 & $8,22 \mathrm{E}-05$ & $9,33 \mathrm{E}-05$ & 1023,48 & 1073,13 & $-0,12639$ & $-4,52 \mathrm{E}-05$ & 23,25 \\
\hline 7 & $6,57 \mathrm{E}-05$ & $7,27 \mathrm{E}-05$ & 1123,3 & 1174,06 & $-0,10132$ & $-3,85 \mathrm{E}-05$ & 21,89 \\
\hline 8 & $6,21 \mathrm{E}-05$ & $6,88 \mathrm{E}-05$ & 1224,46 & 1274,72 & $-0,19003$ & $-3,22 \mathrm{E}-05$ & 26,72 \\
\hline
\end{tabular}

Pela análise dos valores apresentados na Tabela 13, nota-se que as energias de ativação aparentes variam entre 21,89 e 50,79 kJ/mol. Observa-se também que há dois grupos de valores, referentes a cinética de baixa e alta temperatura. As energias de ativação determinada até cerca de $925 \mathrm{~K}$ são da ordem de cerca de $35-40 \mathrm{~kJ} / \mathrm{mol}$, à exceção do segundo valor. Em altas temperaturas, os valores tendem a diminuir para cerca de $25 \mathrm{~kJ} / \mathrm{mol}$, mantendo-se até o final. Assim, infere-se que dois mecanismos distintos controladores do processo tomam parte no processo cinético global durante a redução, em função da faixa de temperaturas considerada, onde a mudança de mecanismo ocorre entre 925 e $972 \mathrm{~K}$.

\section{Pelotas Pellet feed B / Redutor: (10\% de hidrogênio + $90 \%$ de argônio).}

A Figura 48 mostra o ciclo de temperatura composta por patamares em função do tempo e a massa em função do tempo para a redução em atmosfera (10\% de hidrogênio + 90\% de argônio) da pelota do pellet feed $\mathrm{B}$. 


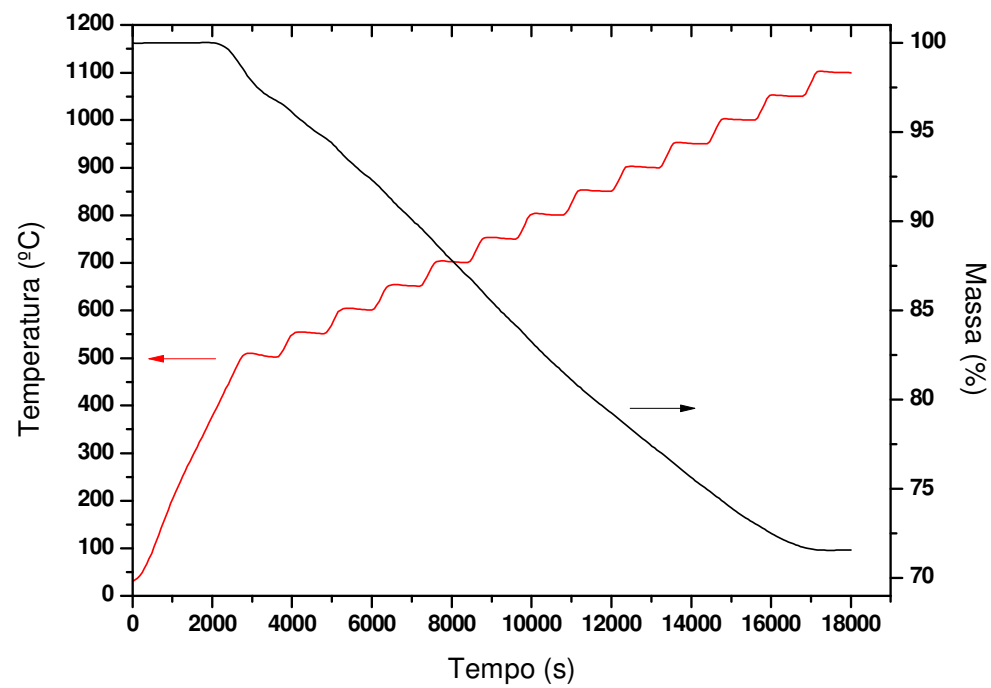

Figura 48: Massa em função do tempo e temperatura em função do tempo. Pelota do pellet feed $\mathrm{B}$ em atmosfera redutora (10\% de hidrogênio + $90 \%$ de argônio).

A perda de massa exibida na Figura 48, foi em torno de $27,5 \%$ e iniciase a partir do primeiro patamar a $500{ }^{\circ} \mathrm{C}$, quando se admite o fluxo de gás redutor. Observa-se também que quando ocorrem os dois últimos patamares, praticamente não mais perda de massa.

A Figura 49 mostra a fração reagida em função do tempo da pelota do pellet feed $\mathrm{B}$.

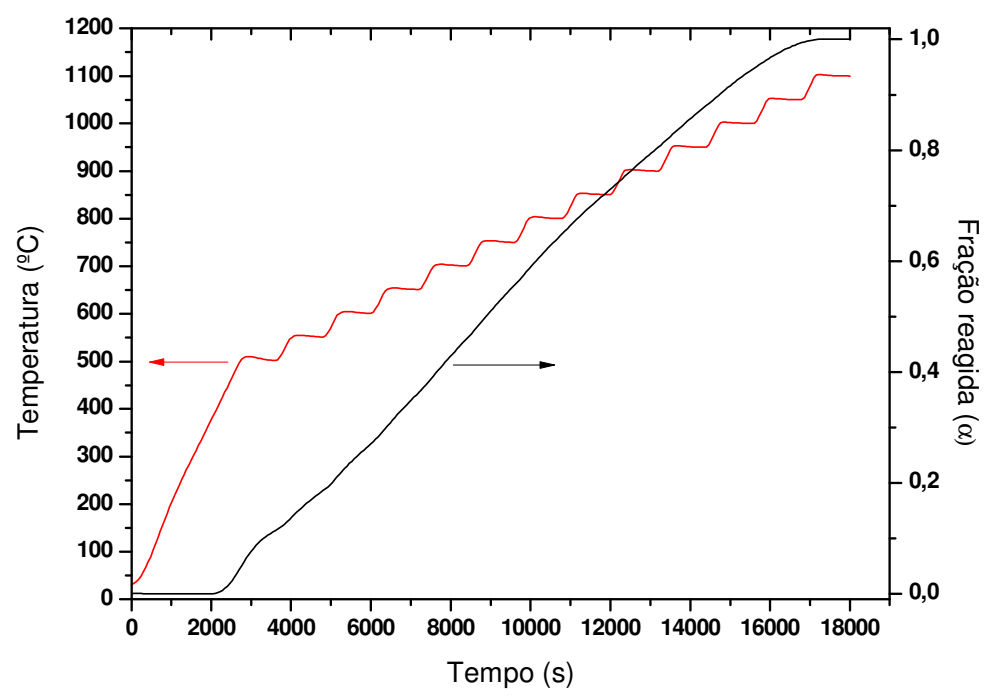

Figura 49: Fração reagida ( $\alpha$ ) em função do tempo. Pelota do pellet feed B em atmosfera redutora (10\% de hidrogênio + $90 \%$ de argônio). 
Observa-se na Figura 49, uma curva do tipo sigmoidal. Nota-se também que a curva torna-se horizontal no penúltimo patamar $\left(1050{ }^{\circ} \mathrm{C}\right)$, indicando não ocorrer mais reação a partir deste ponto.

Na Figura 50 observa-se a aplicação do método Jump para o cálculo da energia de ativação aparente da pelota do pellet feed B reduzido em hidrogênio.

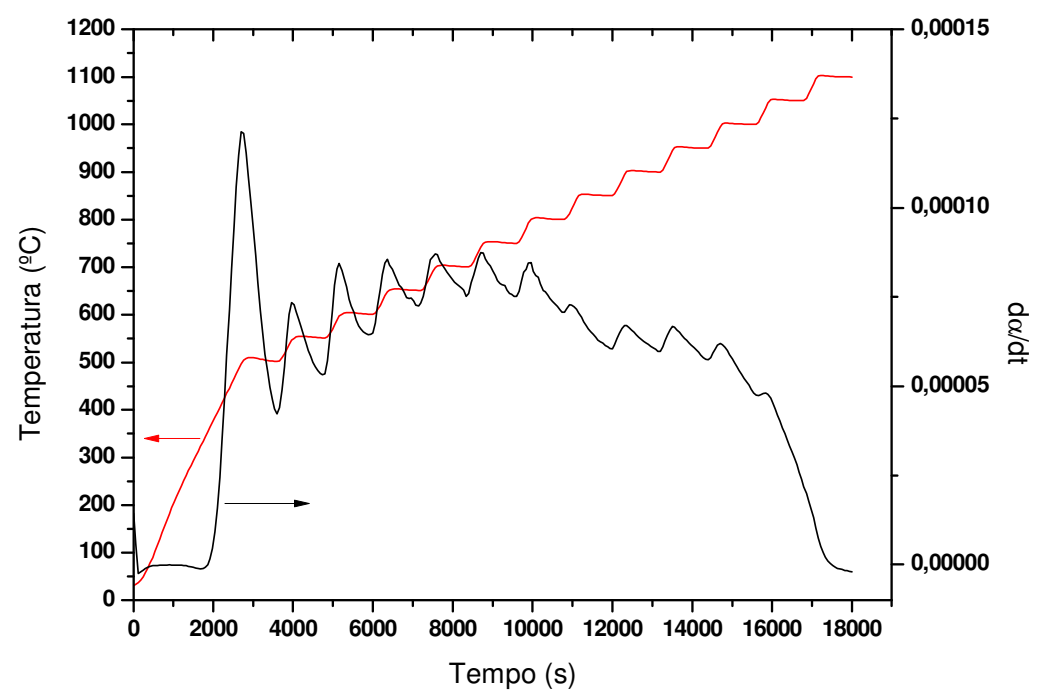

Figura 50: Aplicação do método Jump à análise FSIA. Pelota do pellet feed B em atmosfera redutora de (10\% de hidrogênio $+90 \%$ de argônio).

Na Figura 50 nota-se que $d \alpha / d t$ apresenta variações entre o final de um patamar e o ínicio do patamar subseqüente. As variações são maiores no intervalo entre 2000 e $6000 \mathrm{~s}$, que se referem aos três primeiros picos. Outros picos são de menor amplitude, intercalados por pequeno ombros.

A Tabela 14 mostra os valores das variáveis e da energia de ativação aparente obtidas pelo método Jump aplicado na redução da pelota do pellet feed $B$ reduzida em atmosfera redutora (10\% de hidrogênio $+90 \%$ de argônio). 
Tabela 14: Energias de ativação calculadas através do método Jump. Minério $B$ em atmosfera redutora (10\% de hidrogênio + $90 \%$ de argônio).

\begin{tabular}{|c|c|c|c|c|c|c|c|}
\hline Etapa & $\left(\frac{d \alpha}{d t}\right)_{1}$ & $\left(\frac{d \alpha}{d t}\right)_{2}$ & $T_{1}(K)$ & $T_{2}(K)$ & $\ln \left[(d \alpha / d t)_{1} /(d \alpha / d)_{2}\right]$ & $\frac{1}{T_{2}}-\frac{1}{T_{1}}$ & Ea (kJ/mol) \\
\hline 1 & $4,22 \mathrm{E}-05$ & $7,08 \mathrm{E}-05$ & 774,65 & 826,27 & $-5,17 \mathrm{E}-01$ & $-8,06 \mathrm{E}-05$ & 53,33 \\
\hline 2 & $5,35 \mathrm{E}-05$ & $8,24 \mathrm{E}-05$ & 824,15 & 874,48 & $-0,43095$ & $-6,98 \mathrm{E}-05$ & 51,31 \\
\hline 3 & $6,48 \mathrm{E}-05$ & $8,40 \mathrm{E}-05$ & 873,93 & 924,93 & $-0,25821$ & $-6,31 \mathrm{E}-05$ & 34,03 \\
\hline 4 & $7,25 \mathrm{E}-05$ & $8,69 \mathrm{E}-05$ & 923,96 & 975,29 & $-0,181$ & $-5,70 \mathrm{E}-05$ & 26,42 \\
\hline 5 & $7,52 \mathrm{E}-05$ & $8,77 \mathrm{E}-05$ & 973,78 & 1022,7 & $-0,15395$ & $-4,91 \mathrm{E}-05$ & 26,06 \\
\hline 6 & $6,10 \mathrm{E}-05$ & $6,69 \mathrm{E}-05$ & 1123,5 & 1174,19 & $-0,09299$ & $-3,84 \mathrm{E}-05$ & 20,12 \\
\hline 7 & $6,03 \mathrm{E}-05$ & $6,66 \mathrm{E}-05$ & 1173,39 & 1224,51 & $-0,09841$ & $-3,56 \mathrm{E}-05$ & 23,00 \\
\hline 8 & $5,75 \mathrm{E}-05$ & $6,17 \mathrm{E}-05$ & 1223,24 & 1274,76 & $-0,06957$ & $-3,30 \mathrm{E}-05$ & 17,51 \\
\hline
\end{tabular}

$\mathrm{Na}$ Tabela 14, os valores das energias de ativação aparentes variam entre 17,51 e 53,33 kJ/mol. Uma vez mais, é possível observar grupos de valores de energias de ativação semelhantes no decorrer da faixa de temperatura estudada, indicando detereminados mecanismos vigentes. Dois mecanismos são claramente identificados, ou mesmo três, em se considerando os valores aproximados: 52, 26 e $20 \mathrm{~kJ} / \mathrm{mol}$. O valor determinado no $3^{\circ}$ salto, $34 \mathrm{~kJ} / \mathrm{mol}$, é cracterístico de uma zona de transição de mecanismo controlador.

\section{Pelotas Pellet feed C / Redutor: (10\% de hidrogênio + $90 \%$ de argônio)}

A Figura 51 mostra o ciclo de temperatura composta por patamares, em função do tempo e a perda de massa em função do tempo para a redução em atmosfera redutora (10\% de hidrogênio $+90 \%$ de argônio) da pelota do pellet feed C. 


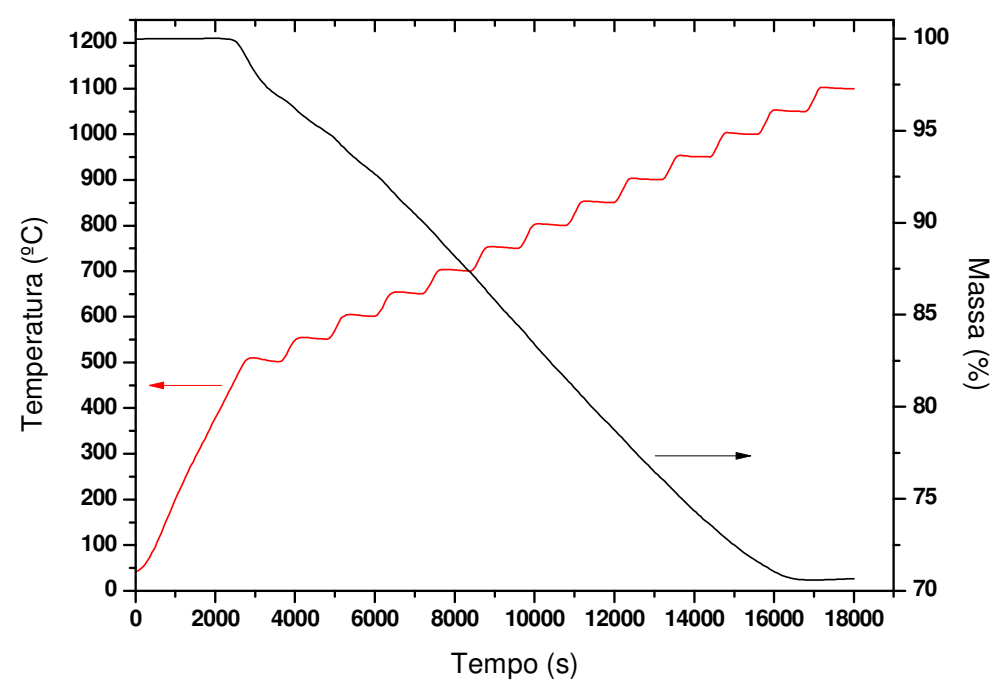

Figura 51: Massa em função do tempo e temperatura em função do tempo. Pelota do pellet feed $\mathrm{C}$ em atmosfera redutora (10\% de hidrogênio $+90 \%$ de argônio).

A perda de massa da curva da Figura 51, foi em torno de $28,5 \%$ e inicia-se a partir do primeiro patamar a $500{ }^{\circ} \mathrm{C}$, quando admite-se o fluxo de gás redutor. Observa-se também que quando ocorrem os dois últimos patamares, praticamente não há mais perda de massa.

A Figura 52 mostra a fração reagida em função do tempo da pelota do pellet feed $\mathrm{C}$.

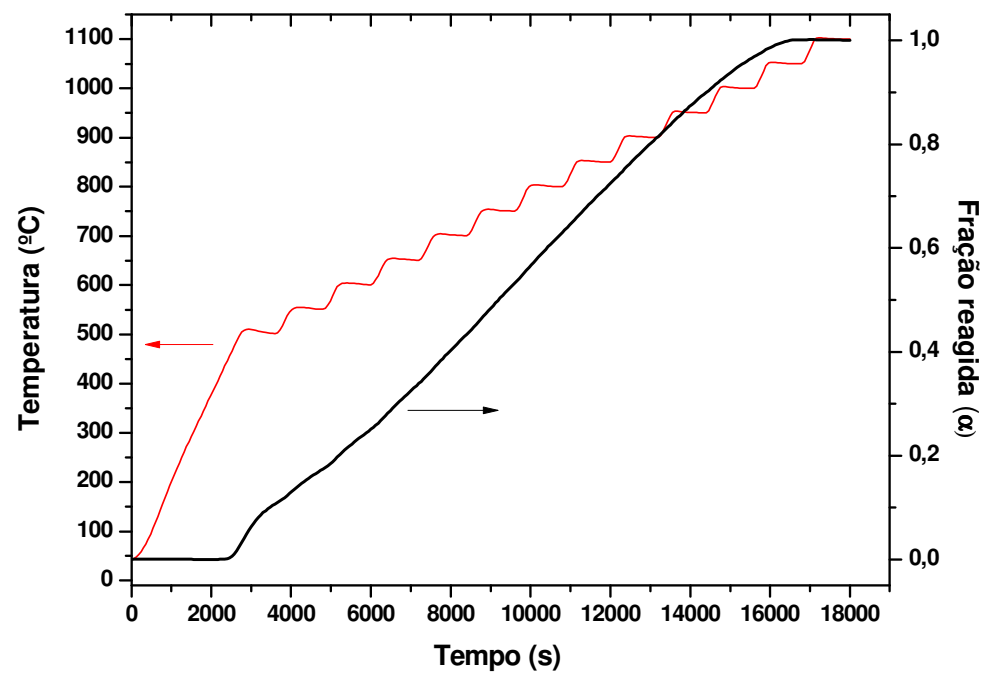

Figura 52: Fração reagida $(\alpha)$ em função do tempo. Pelota do pellet feed $C$ em atmosfera redutora (10\% de hidrogênio + $90 \%$ de argônio). 
Um comportamento semelhante pode ser observado na Figura 52, a curva da fração reagida é uma curva do tipo sigmoidal. Nota-se também que a curva torna-se horizontal no penúltimo patamar $\left(1050^{\circ} \mathrm{C}\right)$, não ocorrendo mais reação a partir deste ponto.

$\mathrm{Na}$

Figura 53, observa-se a aplicação do método Jump para o cálculo da energia de ativação aparente da pelota do pellet feed $\mathrm{C}$ reduzido em atmosfera redutora ( $10 \%$ de hidrogênio $+90 \%$ de argônio).

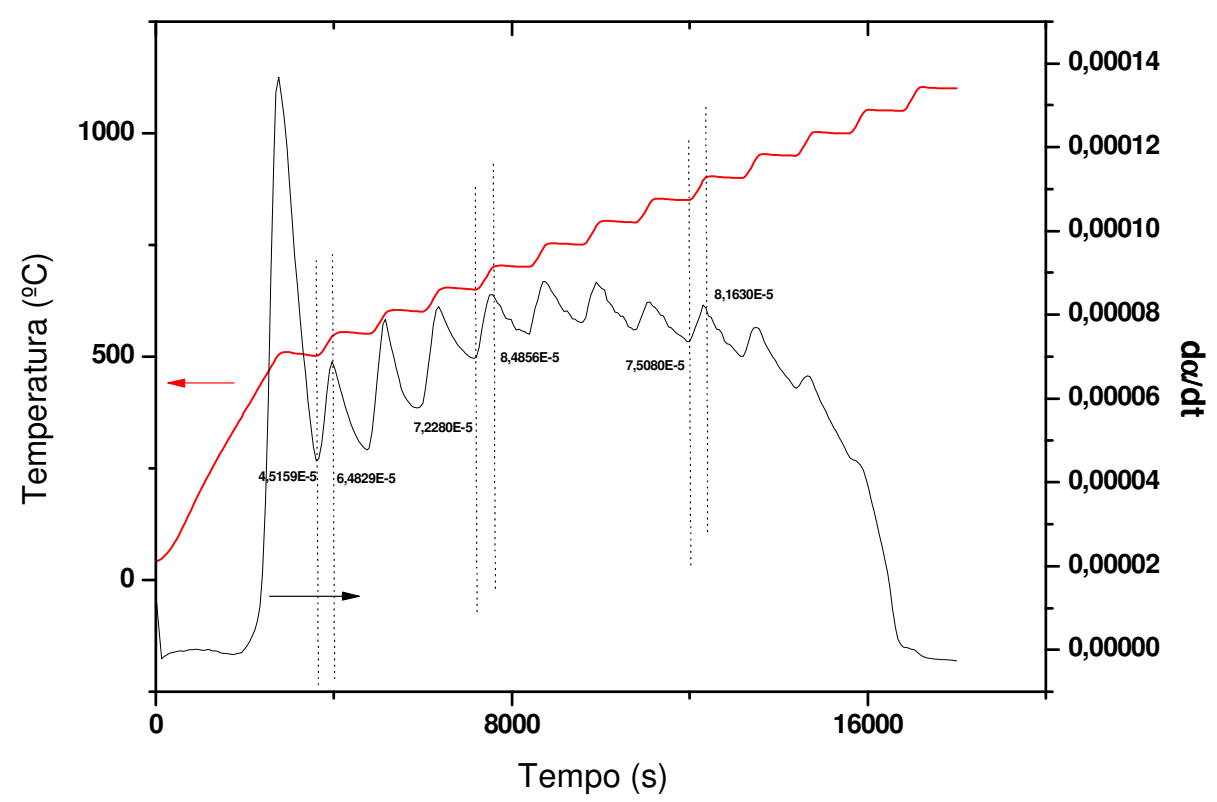

Figura 53: Aplicação do Jump Method à análise FSIA. Pelota do pellet feed C em atmosfera redutora ( $10 \%$ de hidrogênio $+90 \%$ de argônio).

Na Figura 53 nota-se que $d \alpha / d t$ apresenta variações entre o final de um patamar e o ínicio do patamar subseqüente. As variações são maiores no intervalo entre 2000 e $6000 \mathrm{~s}$, que se referem aos três primeiros picos. Outros picos são de menor amplitude, intercalados por pequeno ombros

A Tabela 15 mostra os valores das variáveis e da energia de ativação aparente obtidas pelo método Jump aplicado na redução da pelota do pellet feed $C$ reduzida em atmosfera redutora (10\% de hidrogênio $+90 \%$ de argônio). 
Tabela 15: Energias de ativação calculadas através do método "jump". Pelota do pellet feed $\mathrm{C}$ em atmosfera redutora (10\% de hidrogênio + 90\% de argônio).

\begin{tabular}{|c|c|c|c|c|c|c|c|}
\hline Etapa & $\left(\frac{d \alpha}{d t}\right)_{1}$ & $\left(\frac{d \alpha}{d t}\right)_{2}$ & $T_{1}(K)$ & $T_{2}(K)$ & $\ln \left[(d \alpha / d t)^{1} /(d \alpha / d)_{2}\right]$ & $\frac{1}{T_{2}}-\frac{1}{T_{1}}$ & Ea (kJ/mol) \\
\hline 1 & $4,52 \mathrm{E}-05$ & $6,48 \mathrm{E}-05$ & 776,5 & 826,33 & $-0,36156$ & $-7,77 \mathrm{E}-05$ & 38,71 \\
\hline 2 & $4,77 \mathrm{E}-05$ & $7,60 \mathrm{E}-05$ & 824,4 & 874,53 & $-0,46597$ & $-6,95 \mathrm{E}-05$ & 55,72 \\
\hline 3 & $6,23 \mathrm{E}-05$ & $8,06 \mathrm{E}-05$ & 876,62 & 925 & $-0,25792$ & $-5,97 \mathrm{E}-05$ & 35,94 \\
\hline 4 & $7,23 \mathrm{E}-05$ & $8,49 \mathrm{E}-05$ & 926,78 & 972,02 & $-0,16041$ & $-5,02 \mathrm{E}-05$ & 26,56 \\
\hline 5 & $7,81 \mathrm{E}-05$ & $8,70 \mathrm{E}-05$ & 976,93 & 1025,68 & $-0,10812$ & $-4,87 \mathrm{E}-05$ & 18,48 \\
\hline 6 & $7,94 \mathrm{E}-05$ & $8,69 \mathrm{E}-05$ & 1027,02 & 1073,24 & $-0,08998$ & $-4,19 \mathrm{E}-05$ & 17,84 \\
\hline 7 & $7,51 \mathrm{E}-05$ & $8,16 \mathrm{E}-05$ & 1127,23 & 1174,17 & $-0,08364$ & $-3,55 \mathrm{E}-05$ & 19,61 \\
\hline 8 & $7,14 \mathrm{E}-05$ & $7,67 \mathrm{E}-05$ & 1177,34 & 1224,57 & $-0,07138$ & $-3,28 \mathrm{E}-05$ & 18,12 \\
\hline
\end{tabular}

Para a análise deste pellet feed C, o comportamento lembra aquele obtido no pellet feed A. As energias de ativação determinadas até cerca de $925 \mathrm{~K}$ são da ordem de cerca de $37 \mathrm{~kJ} / \mathrm{mol}$, à exceção do segundo valor. Em altas temperaturas, os valores temdem a se diminuir para cerca de $19 \mathrm{~kJ} / \mathrm{mol}$, á semelhança do primeiro caso estudado, embora a transição de mecanismo controlador ocorra ao longo de um maior intervalo de temperatura, entre 925 e 975 K. Desta forma, 2 mecanismos controladores da redução com hidrogênio podem ser propostos para o pellet feed C.

\section{Pelotas Pellet feed A / Redutor: $\left(10 \% \mathrm{H}_{2}+90 \% \mathrm{Ar}\right)+\mathrm{CO}$}

A Figura 54 mostra o ciclo de temperatura composta por patamares em função do tempo e a perda de massa em função do tempo para a redução em atmosfera de hidrogênio mais monóxido de carbono da pelota do pellet feed $\mathrm{A}$. 


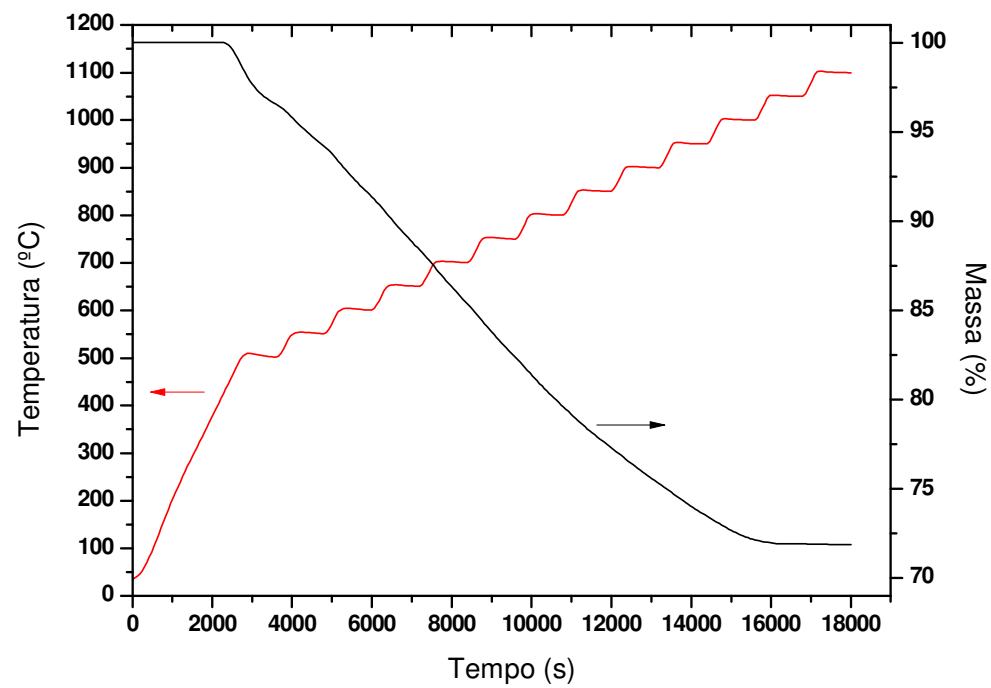

Figura 54: Massa em função do tempo e temperatura em função do tempo. Pelota do pellet feed $\mathrm{A}$ em atmosfera redutora $\left.\left(10 \% \mathrm{H}_{2}+90 \% \mathrm{Ar}\right)+\mathrm{CO}\right)$.

Nota-se da curva de da Figura 54, que a perda de massa inicia-se a partir do primeiro patamar a $500{ }^{\circ} \mathrm{C}$, quando admite-se o fluxo de gás redutor. Observa-se também que quando ocorrem os dois últimos patamares, praticamente não mais perda de massa. Nota-se também que inicialmente, referente ao primeiro patamar a $500{ }^{\circ} \mathrm{C}$ a perda de massa se torna mais acentuada.

A Figura 55 mostra a fração reagida em função do tempo da pelota do pellet feed $\mathrm{A}$.

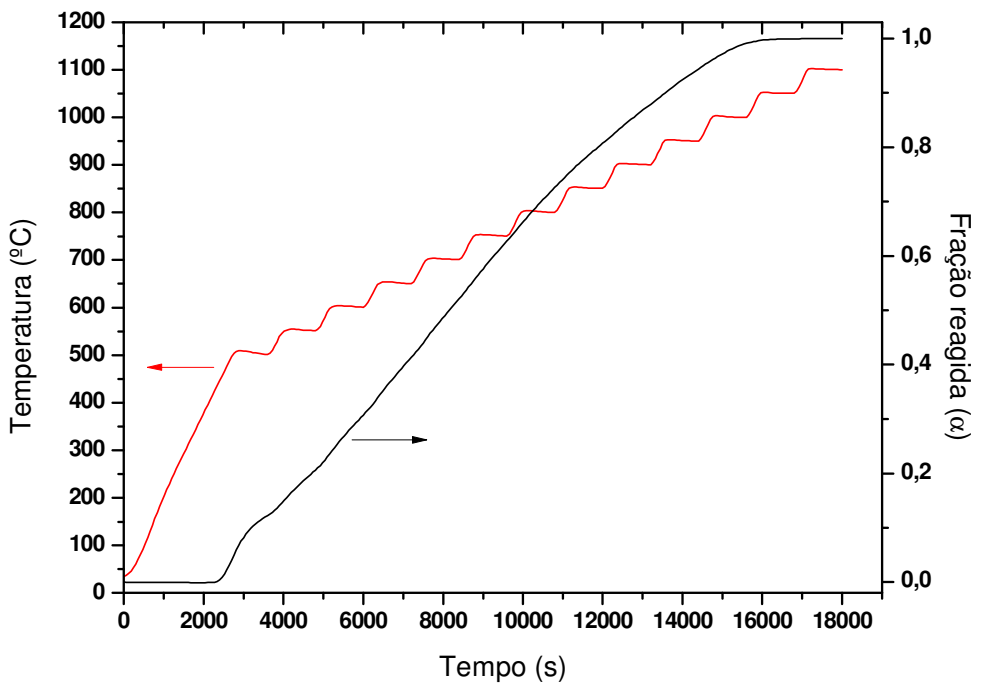

Figura 55: Fração reagida ( $\alpha$ ) em função do tempo. Pelota do pellet feed A em atmosfera redutora $\left.\left(10 \% \mathrm{H}_{2}+90 \% \mathrm{Ar}\right)+\mathrm{CO}\right)$. 
Observa-se na Figura 55, que a curva da fração reagida é uma curva do tipo sigmoidal. Nota-se também que a curva torna-se horizontal no penúltimo patamar $\left(1050{ }^{\circ} \mathrm{C}\right)$, não ocorrendo mais reação a partir deste ponto.

Na Figura 56, observa-se a aplicação do método Jump para o cálculo da energia de ativação aparente da pelota do pellet feed $\mathrm{A}$ reduzido em hidrogênio mais monóxido de carbono.

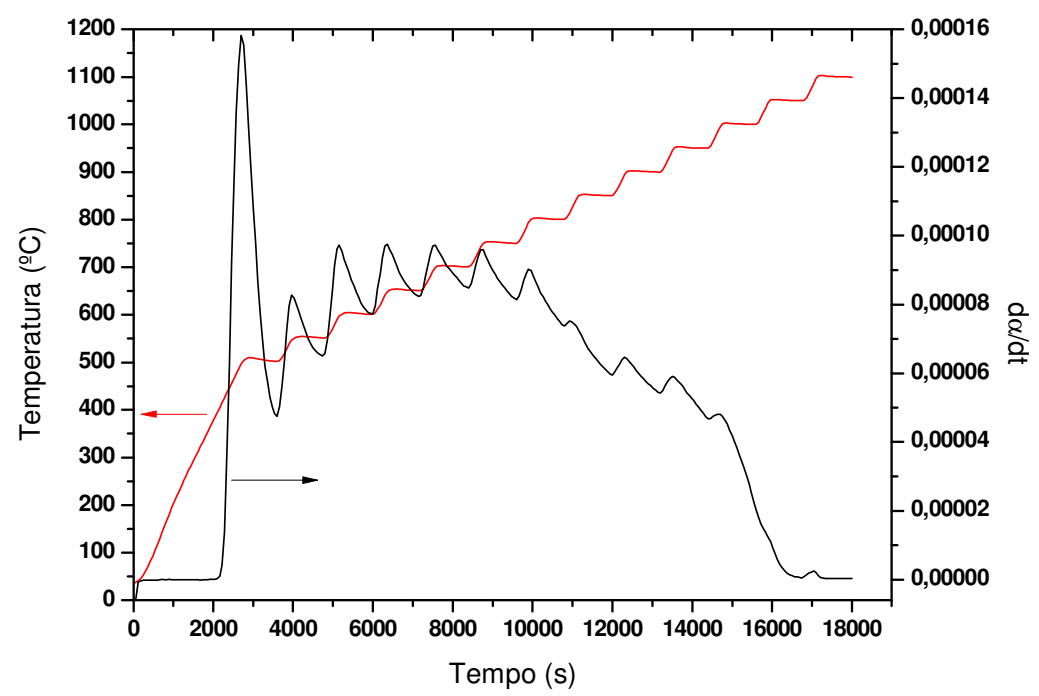

Figura 56: Aplicação do Jump Method à análise FSIA. Pelota do pellet feed A em atmosfera redutora $\left.\left(10 \% \mathrm{H}_{2}+90 \% \mathrm{Ar}\right)+\mathrm{CO}\right)$.

Observa-se na Figura 56 que $d \alpha / d t$ apresenta variações entre o final de um patamar e o ínicio do patamar subseqüente. As variações são maiores no intervalo entre 2000 e $6000 \mathrm{~s}$, que se referem aos três primeiros picos. Outros picos são de menor amplitude, intercalados por pequenos ombros.

A Tabela 16 mostra os valores das variáveis e da energia de ativação aparente obtidas pelo método Jump aplicado na redução da pelota do pellet feed A reduzida com hidrogênio mais monóxido de carbono. 
Tabela 16: Energias de ativação calculadas através do método Jump. Pelota do pellet feed $\mathrm{A}$ em atmosfera redutora de $\left(10 \% \mathrm{H}_{2}+90 \% \mathrm{Ar}\right)+\mathrm{CO}$.

\begin{tabular}{|c|c|c|c|c|c|c|c|}
\hline Etapa & $\left(\frac{d \alpha}{d t}\right)_{1}$ & $\left(\frac{d \alpha}{d t}\right)_{2}$ & $T_{1}(K)$ & $T_{2}(K)$ & $\ln \left[(d \alpha / d t)_{1} /(d \alpha / d)_{2}\right]$ & $\frac{1}{T_{2}}-\frac{1}{T_{1}}$ & Ea (kJ/mol) \\
\hline 1 & $4,75 \mathrm{E}-05$ & $8,18 \mathrm{E}-05$ & 774,61 & 823,74 & $-0,54441$ & $-7,70 \mathrm{E}-05$ & 58,79 \\
\hline 2 & $6,50 \mathrm{E}-05$ & $9,53 \mathrm{E}-05$ & 824,4 & 874,36 & $-0,3824$ & $-6,93 \mathrm{E}-05$ & 45,87 \\
\hline 3 & $7,73 \mathrm{E}-05$ & $9,61 \mathrm{E}-05$ & 873,96 & 924,77 & $-0,21763$ & $-6,29 \mathrm{E}-05$ & 28,78 \\
\hline 4 & $8,27 \mathrm{E}-05$ & $9,60 \mathrm{E}-05$ & 924,16 & 975,06 & $-0,14893$ & $-5,65 \mathrm{E}-05$ & 21,92 \\
\hline 5 & $8,48 \mathrm{E}-05$ & $9,44 \mathrm{E}-05$ & 973,63 & 1025,29 & $-0,10729$ & $-5,18 \mathrm{E}-05$ & 17,24 \\
\hline 6 & $8,14 \mathrm{E}-05$ & $8,99 \mathrm{E}-05$ & 1023,51 & 1073,21 & $-0,09859$ & $-4,52 \mathrm{E}-05$ & 18,12 \\
\hline 7 & $5,95 \mathrm{E}-05$ & $6,43 \mathrm{E}-05$ & 1123,32 & 1174,01 & $-0,07771$ & $-3,84 \mathrm{E}-05$ & 16,81 \\
\hline 8 & $5,43 \mathrm{E}-05$ & $5,88 \mathrm{E}-05$ & 1173,26 & 1224,36 & $-0,08065$ & $-3,56 \mathrm{E}-05$ & 18,85 \\
\hline
\end{tabular}

Pela análise dos valores apresentados na Tabela 16, nota-se que as energias de ativação aparentes variam entre 16,81 e 58,79kJ/mol. Observa-se também que há dois grupos de valores referentes a cinética de baixa e alta temperatura. As energias de ativação determinadas até cerca de $925 \mathrm{~K}$ são da ordem de cerca de $29-52 \mathrm{~kJ} / \mathrm{mol}$, à exceção do primeiro valor. Em altas temperaturas, os valores temdem a diminuir para cerca de $19 \mathrm{~kJ} / \mathrm{mol}$, mantendo-se até o final. Assim, infere-se que dois mecanismos distintos controladores do processo tomam parte no processo cinético global durante a redução, em função da faixa de temperaturas considerada, onde a mudança de mecanismo ocorre entre 925 e $972 \mathrm{~K}$.

\section{Pelotas Pellet feed B / Redutor: $\left(10 \% \mathrm{H}_{2}+90 \% \mathrm{Ar}\right)+\mathrm{CO}$}

A Figura 57 mostra o ciclo de temperatura composta por patamares em função do tempo e a perda de massa em função do tempo para a redução em atmosfera de hidrogênio mais monóxido de carbono da pelota do pellet feed $\mathrm{B}$. 


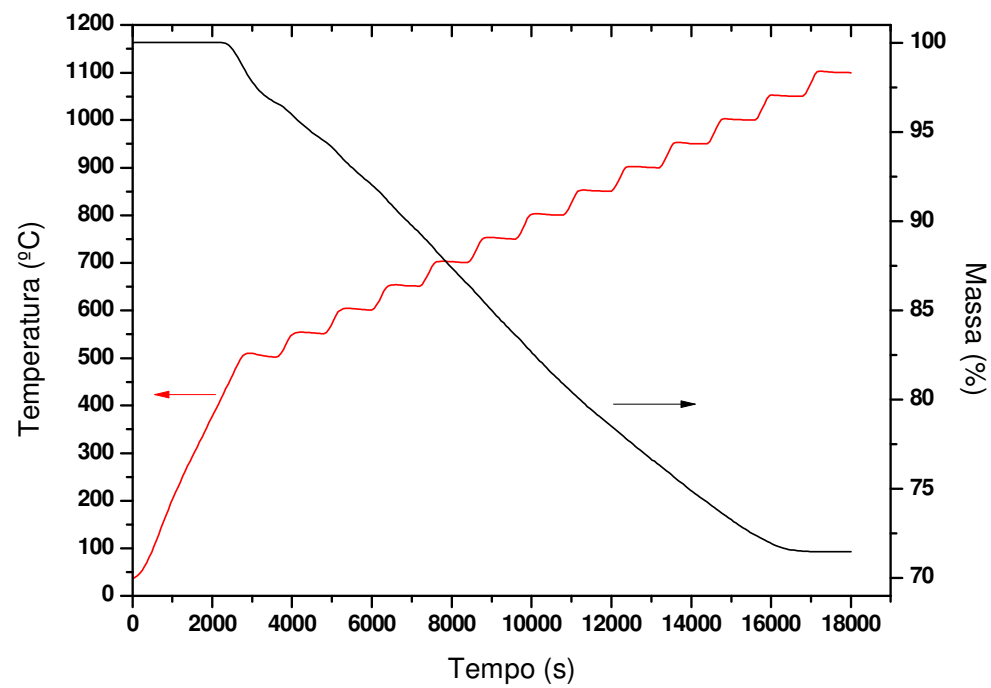

Figura 57: Massa em função do tempo e temperatura em função do tempo. Pelota do pellet feed $\mathrm{B}$ em atmosfera redutora de $\left(10 \% \mathrm{H}_{2}+90 \% \mathrm{Ar}\right)+\mathrm{CO}$.

$\mathrm{Na}$ Figura 57, observa-se que a perda de massa inicia-se a partir do primeiro patamar a $500{ }^{\circ} \mathrm{C}$, quando se inicia o fluxo de gás redutor, nota-se também que neste patamar a curva de perda de massa é mais acentuada,. Observa-se também que quando ocorrem os dois últimos patamares, praticamente não mais perda de massa ou seja a curva torna-se horizontal.

A Figura 58 mostra a fração reagida em função do tempo da pelota do pellet feed $\mathrm{B}$.

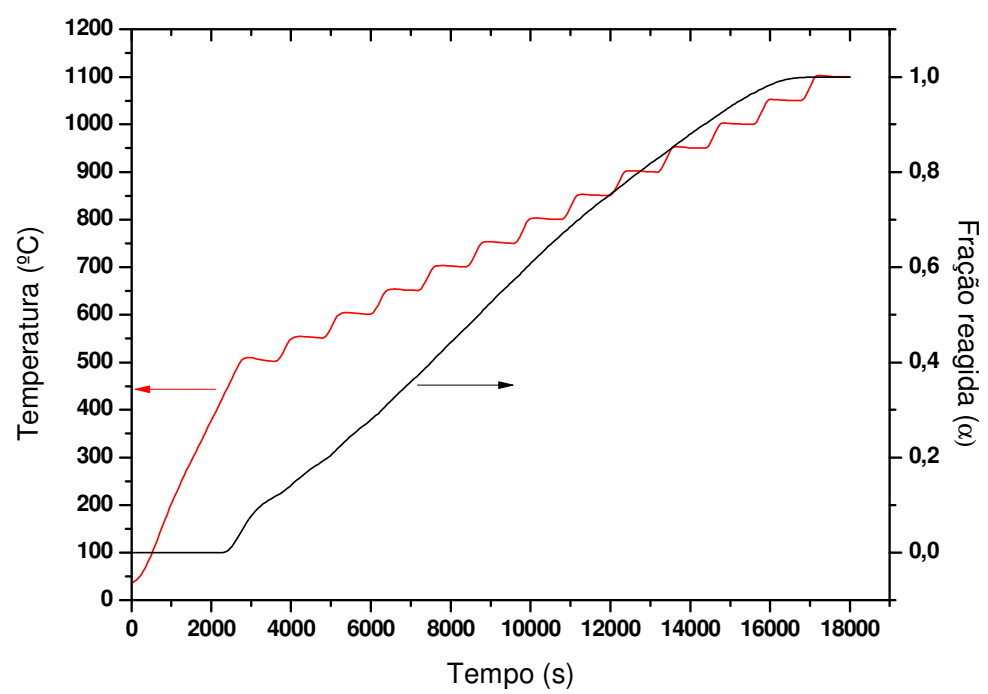

Figura 58: Fração reagida $(\alpha)$ em função do tempo. Pelota do pellet feed $B$ em atmosfera redutora de $\left(10 \% \mathrm{H}_{2}+90 \% \mathrm{Ar}\right)+\mathrm{CO}$. 
Na Figura 58, que a curva da fração reagida, assim como nos casos comentados anteriormente é uma curva do tipo sigmoidal. Nota-se também que a curva torna-se horizontal no penúltimo patamar $\left(1050{ }^{\circ} \mathrm{C}\right)$, não ocorrendo mais reação a partir deste ponto.

Na Figura 59, observa-se a aplicação do método Jump para o cálculo da energia de ativação aparente da pelota do pellet feed $\mathrm{B}$ reduzido em hidrogênio mais monóxido de carbono.



Figura 59: Aplicação do Jump Method à análise FSIA. Pelota do pellet feed B em atmosfera redutora de $\left(10 \% \mathrm{H}_{2}+90 \% \mathrm{Ar}\right)+\mathrm{CO}$.

Observa-se na Figura 59 que $d \alpha / d t$ apresenta variações. Apresentando o primeiro pico maior que os outros picos da mesma curva. Em seguida as variações de $d \alpha / d t$ no intervalo entre 3000 e 6000 s são menores que 0 primeiro pico e maiores que os demais picos. A Tabela 17 mostra os valores das variáveis e da energia de ativação aparente obtidas pelo método Jump aplicado na redução da pelota do pellet feed $\mathrm{B}$ reduzida com hidrogênio mais monóxido de carbono. 
Tabela 17: Energias de ativação calculadas através do método Jump. Minério B em atmosfera redutora de $\left(10 \% \mathrm{H}_{2}+90 \% \mathrm{Ar}\right)+\mathrm{CO}$.

\begin{tabular}{|c|c|c|c|c|c|c|c|}
\hline Etapa & $\left(\frac{d \alpha}{d t}\right)_{1}$ & $\left(\frac{d \alpha}{d t}\right)_{2}$ & $T_{1}(K)$ & $T_{2}(K)$ & $\ln \left[(d \alpha / d t)_{1} /(d \alpha / d)_{2}\right]$ & $\frac{1}{T_{2}}-\frac{1}{T_{1}}$ & Ea (kJ/mol) \\
\hline 1 & $4,46 \mathrm{E}-05$ & $7,47 \mathrm{E}-05$ & 774,59 & 823,68 & $-0,51553$ & $-7,69 \mathrm{E}-05$ & 55,71 \\
\hline 2 & $5,55 \mathrm{E}-05$ & $8,32 \mathrm{E}-05$ & 824,19 & 874,31 & $-0,40469$ & $-6,96 \mathrm{E}-05$ & 48,38 \\
\hline 3 & $6,70 \mathrm{E}-05$ & $8,57 \mathrm{E}-05$ & 873,99 & 924,73 & $-0,24549$ & $-6,28 \mathrm{E}-05$ & 32,51 \\
\hline 4 & $7,58 \mathrm{E}-05$ & $8,79 \mathrm{E}-05$ & 923,8 & 975,03 & $-0,14865$ & $-5,69 \mathrm{E}-05$ & 21,73 \\
\hline 5 & $7,96 \mathrm{E}-05$ & $8,82 \mathrm{E}-05$ & 973,63 & 1025,3 & $-0,10258$ & $-5,18 \mathrm{E}-05$ & 16,48 \\
\hline 6 & $7,92 \mathrm{E}-05$ & $8,59 \mathrm{E}-05$ & 1027,26 & 1073,17 & $-0,08165$ & $-4,16 \mathrm{E}-05$ & 16,30 \\
\hline 7 & $6,25 \mathrm{E}-05$ & $6,74 \mathrm{E}-05$ & 1123,32 & 1174,01 & $-0,07628$ & $-3,84 \mathrm{E}-05$ & 16,50 \\
\hline 8 & $5,95 \mathrm{E}-05$ & $6,48 \mathrm{E}-05$ & 1173,32 & 1224,36 & $-0,08566$ & $-3,55 \mathrm{E}-05$ & 20,05 \\
\hline
\end{tabular}

Em uma análise dos valores apresentados na Tabela 17, nota-se que as energias de ativação aparentes variam entre 16,30 e 55,71kJ/mol. Constata-se um comportamento semelhante aos casos citados anteriormente, ou seja, é possível observar grupos de valores de energias de ativação semelhantes no decorrer da faixa de temperatura estudada, indicando detereminados mecanismos vigentes. Dois mecanismos são claramente identificados, ou mesmo três, em se considerando os valores aproximados: 52, 26 e 17 kJ/mol. O valor determinado no $3^{\circ}$ salto, $32 \mathrm{~kJ} / \mathrm{mol}$, é cracterístico de uma zona de transição de mecanismo controlador.

\section{Pelotas Pellet feed C / Redutor: $\left(10 \% \mathrm{H}_{2}+90 \% \mathrm{Ar}\right)+\mathrm{CO}$}

A Figura 60 mostra o ciclo de temperatura, composta por patamares, em função do tempo e a perda de massa em função do tempo para a redução em atmosfera de hidrogênio mais monóxido de carbono da pelota do pellet feed $\mathrm{C}$. 


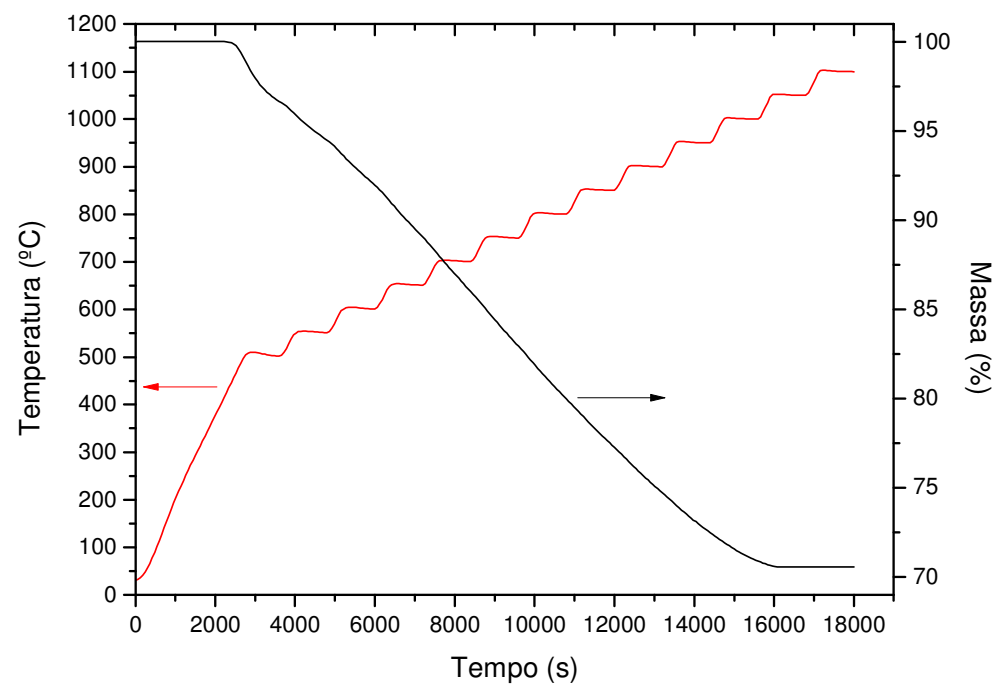

Figura 60: Massa em função do tempo e temperatura em função do tempo. Pelota do pellet feed $\mathrm{C}$ em atmosfera redutora de $\left(10 \% \mathrm{H}_{2}+90 \% \mathrm{Ar}\right)+\mathrm{CO}$.

$\mathrm{Na}$ Figura 60, observa-se que a perda de massa inicia-se a partir do primeiro patamar a $500{ }^{\circ} \mathrm{C}$, quando admite-se o fluxo de gás redutor, nota-se também que neste patamar a curva de perda de massa é mais acentuada,. Observa-se também que quando ocorrem os dois últimos patamares, praticamente não mais perda de massa ou seja a a curva torna-se horizontal.

A Figura 61 mostra a fração reagida em função do tempo da pelota do pellet feed $\mathrm{C}$.

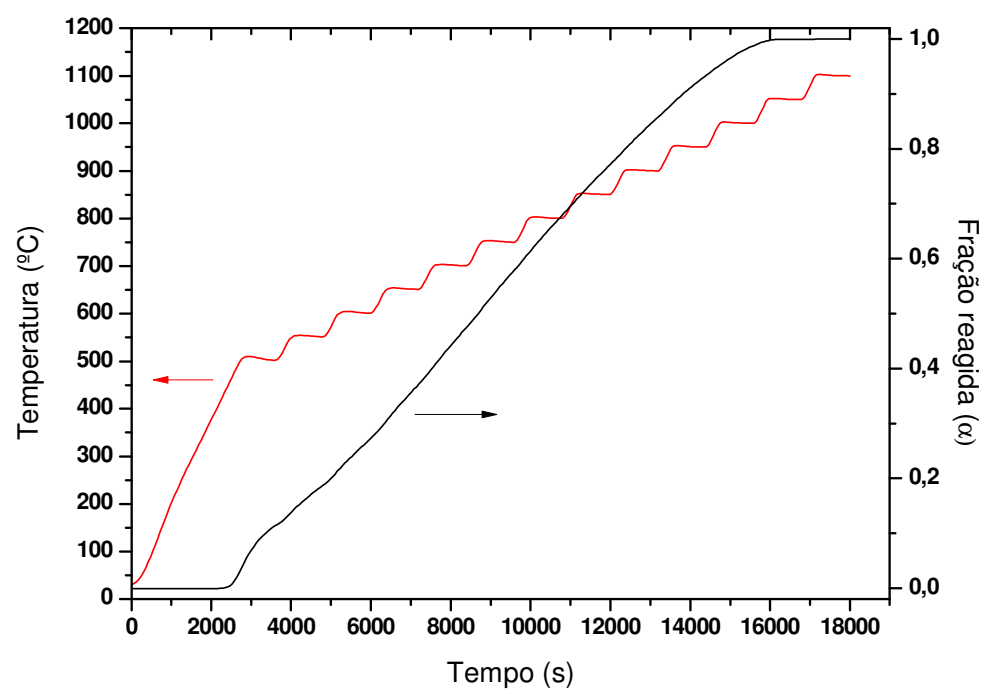

Figura 61: Fração reagida ( $\alpha$ ) em função do tempo. Pelota do pellet feed $\mathrm{C}$ em atmosfera redutora de $\left(10 \% \mathrm{H}_{2}+90 \% \mathrm{Ar}\right)+\mathrm{CO}$. 
A curva da fração reagida da Figura 61 é uma curva do tipo sigmoidal. A curva torna-se constante no penúltimo patamar $\left(1050{ }^{\circ} \mathrm{C}\right)$, indicando não ocorrer reação a partir deste ponto.

Na Figura 62, observa-se a aplicação do método Jump para o cálculo da energia de ativação aparente da pelota do pellet feed $\mathrm{C}$ reduzido em hidrogênio mais monóxido de carbono.

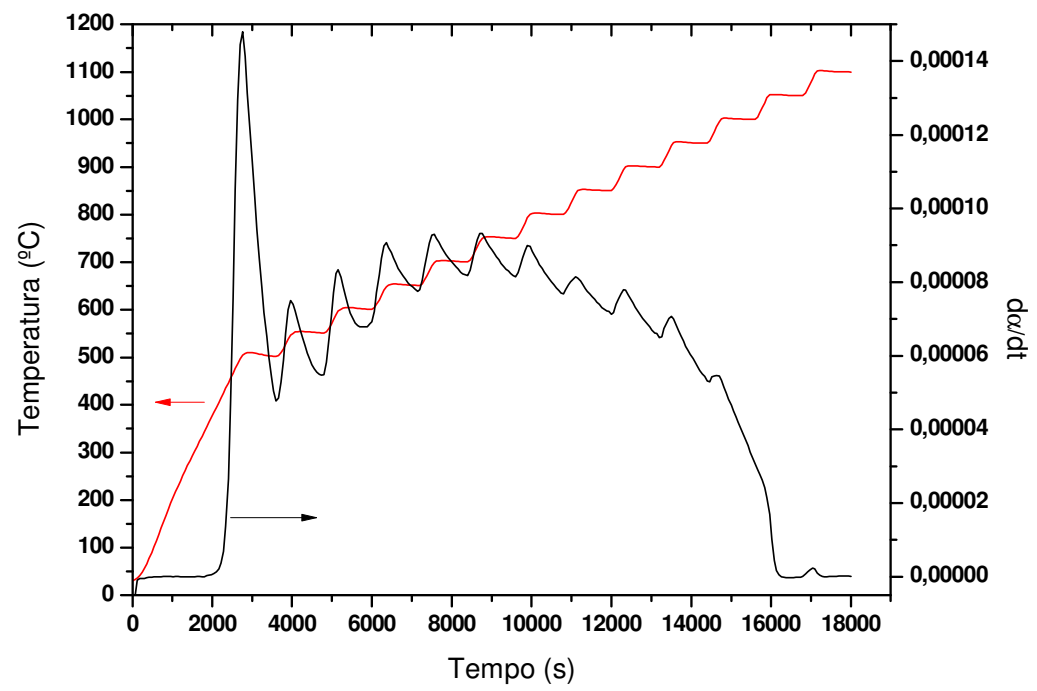

Figura 62: Aplicação do Jump Method à análise FSIA. Pelota do pellet feed C em atmosfera redutora de $\left(10 \% \mathrm{H}_{2}+90 \% \mathrm{Ar}\right)+\mathrm{CO}$.

A Tabela 18 mostra os valores das variáveis e da energia de ativação aparente obtidas pelo método Jump aplicado na redução da pelota do pellet feed $\mathrm{C}$ reduzida com hidrogênio.

Tabela 18: Energias de ativação calculadas através do método Jump. Pellet feed $\mathrm{C}$ em atmosfera redutora de $\left(10 \% \mathrm{H}_{2}+90 \% \mathrm{Ar}\right)+\mathrm{CO}$.

\begin{tabular}{|c|c|c|c|c|c|c|c|}
\hline Etapa & $\left(\frac{d \alpha}{d t}\right)_{1}$ & $\left(\frac{d \alpha}{d t}\right)_{2}$ & $T_{1}(K)$ & $T_{2}(K)$ & $\ln \left[(d \alpha / d t)_{1} /(d \alpha / d)_{2}\right]$ & $\frac{1}{T_{2}}-\frac{1}{T_{1}}$ & Ea (kJ/mol) \\
\hline 1 & $4,77 \mathrm{E}-05$ & $7,39 \mathrm{E}-05$ & 774,67 & 823,79 & $-4,38 \mathrm{E}-01$ & $-7,70 \mathrm{E}-05$ & 47,29 \\
\hline 2 & $5,49 \mathrm{E}-05$ & $8,13 \mathrm{E}-05$ & 824,82 & 874,44 & $-0,39177$ & $-6,88 \mathrm{E}-05$ & 47,35 \\
\hline 3 & $6,78 \mathrm{E}-05$ & $8,94 \mathrm{E}-05$ & 874,46 & 924,46 & $-0,27715$ & $-6,19 \mathrm{E}-05$ & 37,26 \\
\hline 4 & $7,76 \mathrm{E}-05$ & $9,19 \mathrm{E}-05$ & 923 & 975,04 & $-0,16981$ & $-5,78 \mathrm{E}-05$ & 24,42 \\
\hline 5 & $8,18 \mathrm{E}-05$ & $9,22 \mathrm{E}-05$ & 973,65 & 1025,22 & $-0,11953$ & $-5,17 \mathrm{E}-05$ & 19,24 \\
\hline 6 & $8,14 \mathrm{E}-05$ & $8,97 \mathrm{E}-05$ & 1023,52 & 1073,13 & $-0,09692$ & $-4,52 \mathrm{E}-05$ & 17,84 \\
\hline 7 & $7,12 \mathrm{E}-05$ & $7,78 \mathrm{E}-05$ & 1123,31 & 1173,9 & $-0,0883$ & $-3,84 \mathrm{E}-05$ & 19,14 \\
\hline 8 & $6,50 \mathrm{E}-05$ & $7,00 \mathrm{E}-05$ & 1173,27 & 1224,29 & $-0,07496$ & $-3,55 \mathrm{E}-05$ & 17,55 \\
\hline
\end{tabular}


Em uma análise dos valores apresentados na Tabela 18, nota-se que as energias de ativação aparentes variam entre 17,84 e 47,35kJ/mol. Semelhante aos casos estudados anteriormente, é possível observar grupos de valores de energias de ativação semelhantes no decorrer da faixa de temperatura estudada, indicando detereminados mecanismos vigentes. Dois grupos de valores são observados em torno de 45 e $20 \mathrm{~kJ} / \mathrm{mol}$, indicando dois possíveis mecanismos controladores do processo de redução.

A Tabela 19 mostra um resumo das energias de ativação aparente calculadas pelo Método Jump para cada um dos três minérios reduzidos em atmosfera de hidrogênio e hidrogênio mais monóxido de carbono.

Tabela 19: Resumo das energias de ativação aparentes calculadas pelo Método Jump dos Pellets feed A, B e C utilizando atmosfera de $\mathrm{H}_{2}$ (10\% de hidrogênio $+90 \%$ de argônio) e $\mathrm{H}_{2}+\mathrm{CO}$ ((10\% de hidrogênio + $90 \%$ de argônio) + monóxido de carbono)

\begin{tabular}{|c|c|c|c|c|c|c|}
\hline \multicolumn{7}{|c|}{ Energia de Ativação aparente (Ea) Calculada pelo método JUMP } \\
\hline \multirow{3}{*}{ Etapa } & $\mathbf{A}\left(\mathbf{H}_{\mathbf{2}}\right)$ & $\begin{array}{c}\mathbf{A} \\
\left(\mathbf{H}_{\mathbf{2}} \mathbf{C O}\right)\end{array}$ & $\mathbf{B}\left(\mathbf{H}_{\mathbf{2}}\right)$ & $\begin{array}{c}\mathbf{B} \\
\left(\mathbf{H}_{\mathbf{2}} \mathbf{C O}\right)\end{array}$ & $\mathbf{C}\left(\mathbf{H}_{\mathbf{2}}\right)$ & $\begin{array}{c}\mathbf{C} \\
\left(\mathbf{H}_{\mathbf{2}} \mathbf{C O}\right)\end{array}$ \\
\cline { 2 - 7 } & $\mathrm{Ea}(\mathrm{kJ} / \mathrm{mol})$ & $\begin{array}{c}\mathrm{Ea} \\
(\mathrm{kJ} / \mathrm{mol})\end{array}$ & $\begin{array}{c}\mathrm{Ea} \\
(\mathrm{kJ} / \mathrm{mol})\end{array}$ & $\begin{array}{c}\mathrm{Ea} \\
(\mathrm{kJ} / \mathrm{mol})\end{array}$ & $\begin{array}{c}\mathrm{Ea} \\
(\mathrm{kJ} / \mathrm{mol})\end{array}$ & $\begin{array}{c}\mathrm{Ea} \\
(\mathrm{kJ} / \mathrm{mol})\end{array}$ \\
\hline $\mathbf{1}$ & 39,82 & 58,79 & 53,33 & 55,71 & 38,71 & 47,29 \\
\hline $\mathbf{2}$ & 50,79 & 45,87 & 51,31 & 48,38 & 55,72 & 47,35 \\
\hline $\mathbf{3}$ & 34,8 & 28,78 & 34,03 & 32,51 & 35,94 & 37,26 \\
\hline $\mathbf{4}$ & 27,73 & 21,92 & 26,42 & 21,73 & 26,56 & 24,42 \\
\hline $\mathbf{5}$ & 25,47 & 17,24 & 26,06 & 16,48 & 18,48 & 19,24 \\
\hline $\mathbf{6}$ & 23,25 & 18,12 & 21,61 & 16,3 & 17,84 & 17,84 \\
\hline $\mathbf{7}$ & 21,89 & 16,81 & 20,12 & 16,5 & 19,61 & 19,14 \\
\hline $\mathbf{8}$ & 26,72 & 18,85 & 23 & 20,05 & 18,12 & 17,55 \\
\hline
\end{tabular}

A partir das energias de ativação aparentes calculadas neste trabalho pelo método Jump, e resumidas na Tabela 19, observa-se que, o menor valor é $16,3 \mathrm{~kJ}$ e o maior valor é $58,79 \mathrm{~kJ}$. Nota-se também que em todas as análises realizadas ocorre uma dispersão nos valores das energias calculadas. A dispersão indica uma maior sensibilidade devido ao fato de a energia de ativação ser calculada em cada ponto. Nota-se também que, em todos os casos analisados, valores de $E_{a}$ são mais altos no início, ocorrendo uma 
diminuição conforme o prosseguimento da redução. Esta variação indica uma possível mudança no mecanismo de redução.

Em uma comparação mais ampla, nota-se que os valores da Ea das pelotas dos pellets feed $\mathrm{A}$ e $\mathrm{B}$, reduzidas em atmosfera contendo hidrogênio e monóxido de carbono são ligeiramente menores que as $E_{a}$ das pelotas reduzidas em atmosfera contendo apenas hidrogênio como redutor. Uma possível justificativa para esta diminuição da $E_{a}$ em se combinando os fluxos de $\mathrm{H}_{2}$ e CO reside na reação de deslocamento de água (Water-Gás Shift (WGS)). Esta reação consome o produto da redução por hidrogênio, regenerando este redutor.

A reação de deslocamento de água $[115,116]$

$$
\mathrm{CO}+\mathrm{H}_{2} \mathrm{O} \leftrightarrow \mathrm{CO}_{2}+\mathrm{H}_{2}
$$

deve ser levada em consideração, ou seja, esta reação participa do processo global.

De acordo com os resultados de Kuniyoushi e Nurni [115, 116], a superfície das partículas de óxido de ferro ou até mesmo ferro metálico pode ocorrer a formação de um filme (camada) de $\mathrm{H}_{2} \mathrm{O}$ adsorvida, que bloqueia os sítios ativos. $\mathrm{O}$ oxigênio dissociado na molécula de $\mathrm{H}_{2} \mathrm{O}$ é responsável pelo bloqueio dos sítios, inviabilizando-os

$$
\mathrm{H}_{2} \mathrm{O}_{(\mathrm{g})}=\mathrm{H}_{2(\mathrm{~g})}+\mathrm{O}_{(\mathrm{ads})}
$$

Portanto, ao remover as moléculas de $\mathrm{H}_{2} \mathrm{O}$ pela reação WGS ocorre 0 desbloqueio dos sítios. O equilíbrio desta reação é deslocado para a direita com o aumento da temperatura. Sendo assim o aumento da taxa de reação diminiui a $\mathrm{E}_{\mathrm{a}}$, o que explica os resultados obtidos. Além disso, com a redução do pellet feed $\mathrm{C}$ é mostrada a influência que uma maior área superfical exposta é capaz de exercer na $E_{a}$. Este fator, aliado a uma maior quantidade de poros disponíveis, proporciona uma quantidade suficiente de sítios ativo para que ocorra a redução de forma satisfatória, independente do bloqueio realizado pelas moléculas de $\mathrm{H}_{2} \mathrm{O}$ e/ou $\mathrm{O}_{\text {ads. }}$ Assim os resultados sugerem que 0 processo de redução do pellet feed $\mathrm{C}$ independe da espécie do redutor. 
A literatura indica que os valores das energias de ativação aparentes podem depender do material que está sendo reduzido, natureza do gás redutor, faixa de temperatura, etapa da reação, presença de vapor de água, impurezas e forma física. Pineau et. al. $[117,118]$ fizeram um levantamento dos valores das energias de ativação aparente. Para o caso de redução da hematita os valores encontrados variam entre 18 a $246 \mathrm{~kJ} / \mathrm{mol}$ e que para a redução da magnetita, entre 13,4 a $167 \mathrm{~kJ} / \mathrm{mol}$. A ampla faixa de valores confirma que os parâmetros citados anteriormente podem justificar a variação nos valores das energias de ativação aparentes. É comentado também que as energias de ativação aparentes obtidas na redução de óxidos de ferro por hidrogênio e monóxido de carbono são da mesma ordem de grandeza.

A Figura 63 mostra a fração reagida em função do tempo da reação de redução em atmosfera de $\mathrm{H}_{2}+\mathrm{Ar}$ e $\mathrm{H}_{2}+\mathrm{Ar}+\mathrm{CO}$ para as pelotas dos pellets feed $A, B$ e $C$. Os resultados mostram que a taxa de redução é maior na atmosfera contendo $\mathrm{H}_{2}+\mathrm{Ar}+\mathrm{CO}$ para as pelotas $\mathrm{A}$ e $\mathrm{B}$, e em $\mathrm{C}$ a taxa é praticamente a mesma para as atmosferas de $\mathrm{H}_{2}+\mathrm{Ar}$ e $\mathrm{H}_{2}+\mathrm{Ar}+\mathrm{CO}$. Estes dados confirmam $\mathrm{o}$ que foi proposto através dos resultados das energias de ativação apresentada na Tabela 19. 

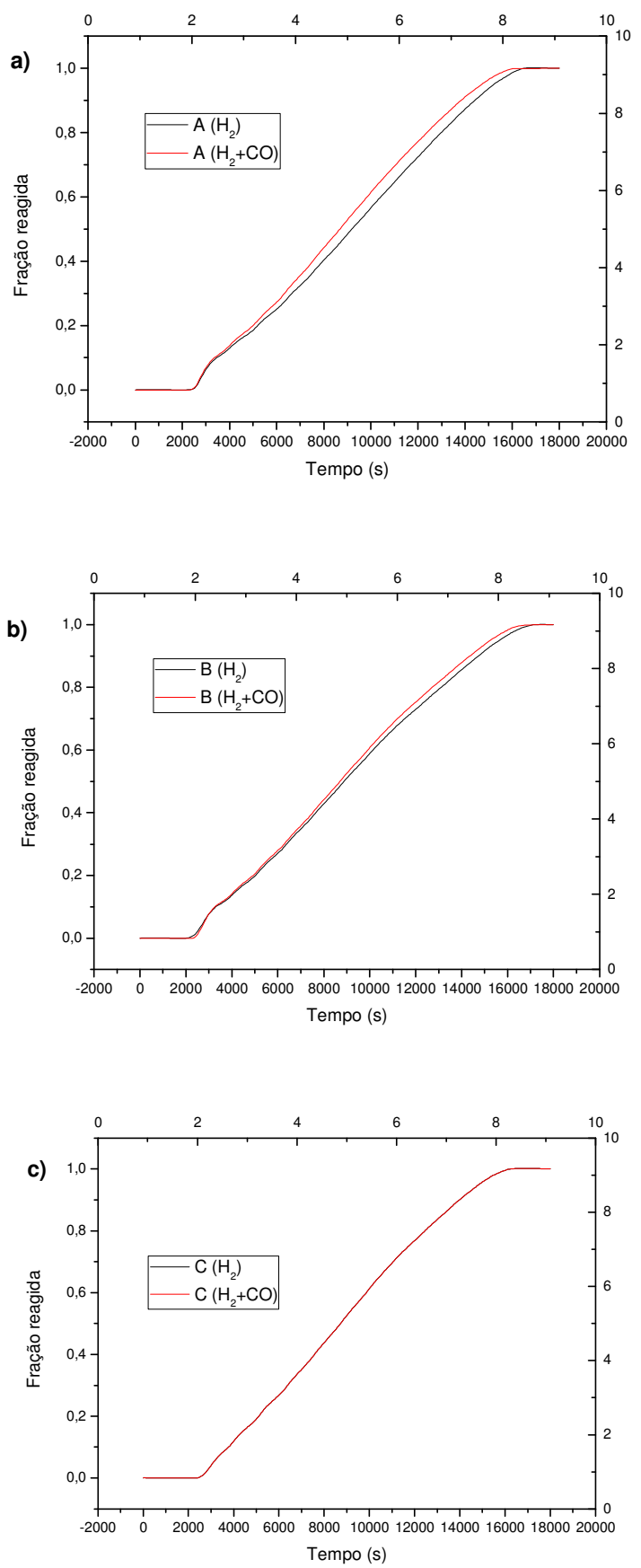

Figura 63: Fração reagida em função do tempo da reação de redução em atmosfera de $\mathrm{H}_{2}+\mathrm{Ar}$ e $\mathrm{H}_{2}+\mathrm{AR}+\mathrm{CO}$ para as pelotas dos pellets feed a) A, b) B e c) C.

A Figura 64, mostra fração reagida versus tempo para as pelotas dos pellets feed $\mathrm{A}$, B e $\mathrm{C}$ reduzidas em atmosferas de $\mathrm{H}_{2}+\mathrm{Ar}$. Observa-se que inicialmente taxa de redução da pelota do pellet feed $\mathrm{C}$ é menor que a taxa de 
redução dos pellets feed $\mathrm{A}$ e $\mathrm{B}$, nota-se também que aproximadamente apartir de 0,1 da fração reagida a taxa de redução de $C$ se torna maior que taxa de redução de $\mathrm{A}$ e $\mathrm{B}$. Estes resultados estão de acordo com a relação entre os valores das energias de ativação calculados na Tabela 19. Este fato pode ser explicado pela maior área de superfície específica de $C$ em relação a $A$ e $B$.

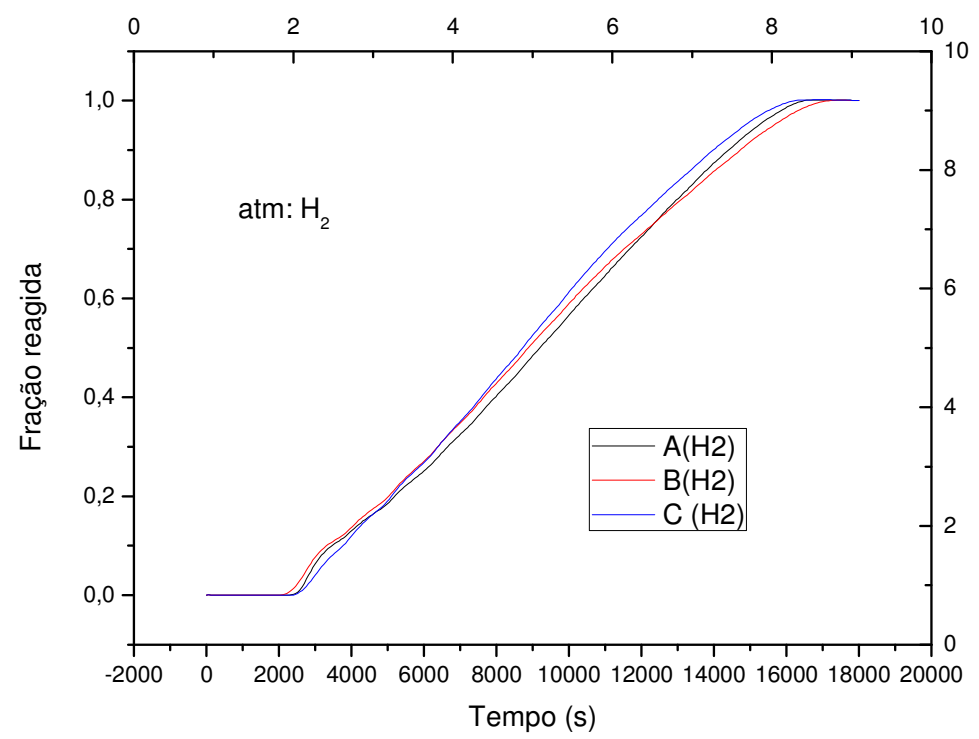

Figura 64: Fração reagida $x$ tempo para as pelotas dos pellets feed $A, B$ e $C$ reduzidas em atmosferas de $\mathrm{H}_{2}+$ Ar.

A Figura 65 mostra fração reagida versus tempo para as pelotas dos pellets feed $\mathrm{A}, \mathrm{B}$ e $\mathrm{C}$ reduzidas em atmosferas de $\mathrm{H}_{2}+\mathrm{Ar}+\mathrm{CO}$. Observa-se que inicialmente taxa de redução da pelota do pellet feed $\mathrm{C}$ é menor que a taxa de redução dos pellets feed $\mathrm{A}$ e $\mathrm{B}$, nota-se também que aproximadamente apartir de 0,2 da fração reagida a taxa de redução das pelotas das pelotas dos pellets feed $A, B$ e $C$ praticamente se tornam iguais. Estes resultados estão de acordo com a relação entre os valores das energias de ativação calculados na Tabela 19. 


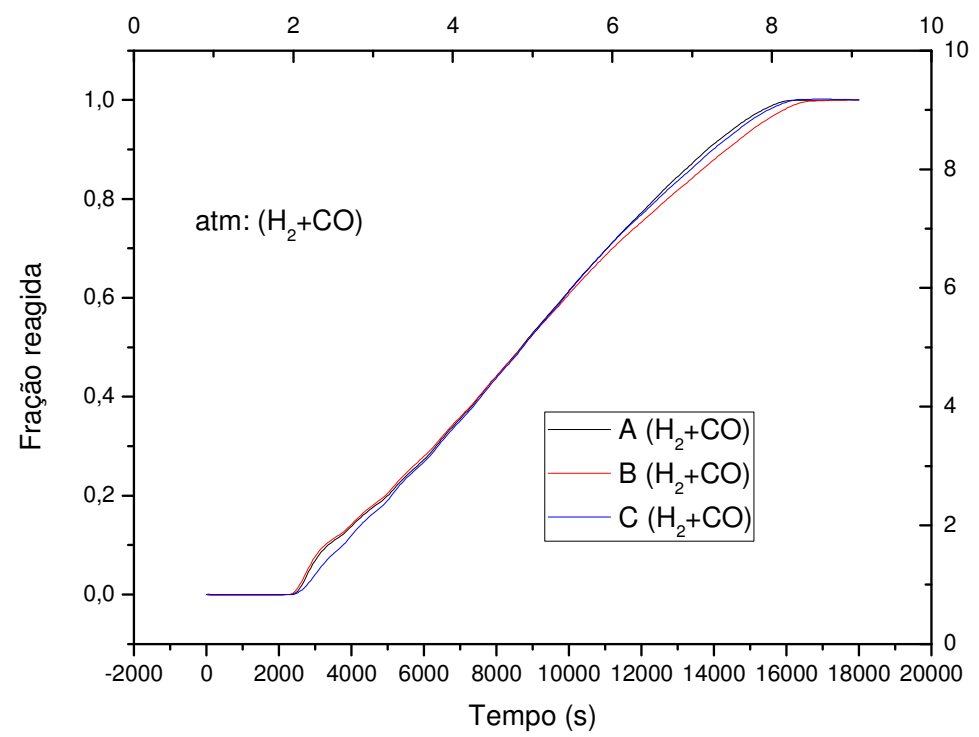

Figura 65: Fração reagida x tempo para as pelotas dos pellets feed A, B e C reduzidas em atmosferas de $\mathrm{H}_{2}+\mathrm{Ar}+\mathrm{CO}$.

Em se considerando a porosidade aparente das pelotas, como mostrada na Tabela 12, constata-se que a influência do volume de poros é menor que o efeito da superfície específica do material em relação à redução. Pode-se notar que a pelota preparada a partir do pellet feed C mais ativo, e com menor energia de ativação, além de maior taxa de redução apresentou metade da porosidade aparente em relação as outras pelotas das amostras A e B. Este fato indica que a difusão gasosa em direção às superfícies, ou seja o acesso do reagente em direção à superfície de reação não é um fator preponderante. Deste modo, uma vez que a difusão foi determinada como sendo a etapa controladora, estes resultados sujerem que a difusão de íons no estado sólido ao longo das camadas reagidas consiste no fator principal. Este resultado está de acordo com a literatura $[60,119]$ sobre a redução de minério ferro.

\subsubsection{Método FSIA}

Para esclarecer os mecanismos e processos envolvidos na redução, empregando o método FSIA, utilizou-se como critério, a linearização nas etapas de construção das curvas com os dados cinéticos e também a 
inclinação negativa das curvas de Arrhenius Ink $\times 1 \backslash T$ visto que a inclinação positiva indica que o mecanismo não é válido.

FSIA aplicado na redução com $\mathrm{H}_{2} \underline{e ~}_{2}+\mathrm{CO}$ das pelotas dos pellet feed A, B e C

A reação sólido-gás envolve uma série de eventos dos quais, geralmente só um será o passo mais lento e, portanto, o passo controlador da velocidade [41].

Para o cálculo das energias de ativação utilizou-se os dados gerados durante a análise SIA forçado. Foram realizados os passos:

1. Construção de gráficos da fração reagida $(\alpha)$ x tempo;

2. Cálculo da derivada da fração reagida em relação ao tempo (da/dt);

3. Plotagem dos gráficos de $\ln (d \alpha / d t) x \ln f(\alpha)$ para cada uma das funções e para cada um dos patamares isotérmicos.

4. Ajuste linear em cada um dos patamares do tipo $y=a x+b$ ou seja $\ln (d \alpha / d t)=a(\ln (f(\alpha))+b$, onde $b=\ln k$

5. Construção do gráfico de $\ln k \times 1 / T$, ajustes lineares do tipo $y=a x+b ;$ tem-se $\ln (k)=-\frac{E_{a}}{R T}+b$ onde $a=-E_{a} / R \Rightarrow E_{a}=-a \cdot R$

Utilizou-se a construção de gráficos $d \alpha / d t \times f(\alpha)$ para os 3 termos $f(\alpha)=\alpha$; $f(\alpha)=(1-\alpha) ; f(\alpha)=[-\ln (1-\alpha)]$. Sendo que a partir dos critérios citados anteriormente, a função $f(\alpha)=-\ln (1-\alpha)$ foi a que apresentou melhor linearização e as curvas de Arrhenius apresentaram inclinações negativas. Com essa constatação, foram calculadas as energias de ativação aparente dos três pellets feed. A Figura 66 mostra como exemplo In (d $\alpha / \mathrm{dt})$ em função de $\ln (\mathrm{f}(\alpha)$ da pelota do pellet feed $B$ no patamar de $800^{\circ} \mathrm{C}$ para as funções a) $f(\alpha)=\alpha$; $b$ ) $f(\alpha)=1-\alpha$ e c) $f(\alpha)=-\ln (1-\alpha)$. Nota-se que a função $f(\alpha)=-\ln (1-\alpha)$ foi a que teve o ajuste liner com o maior $R^{2}$. 
a)
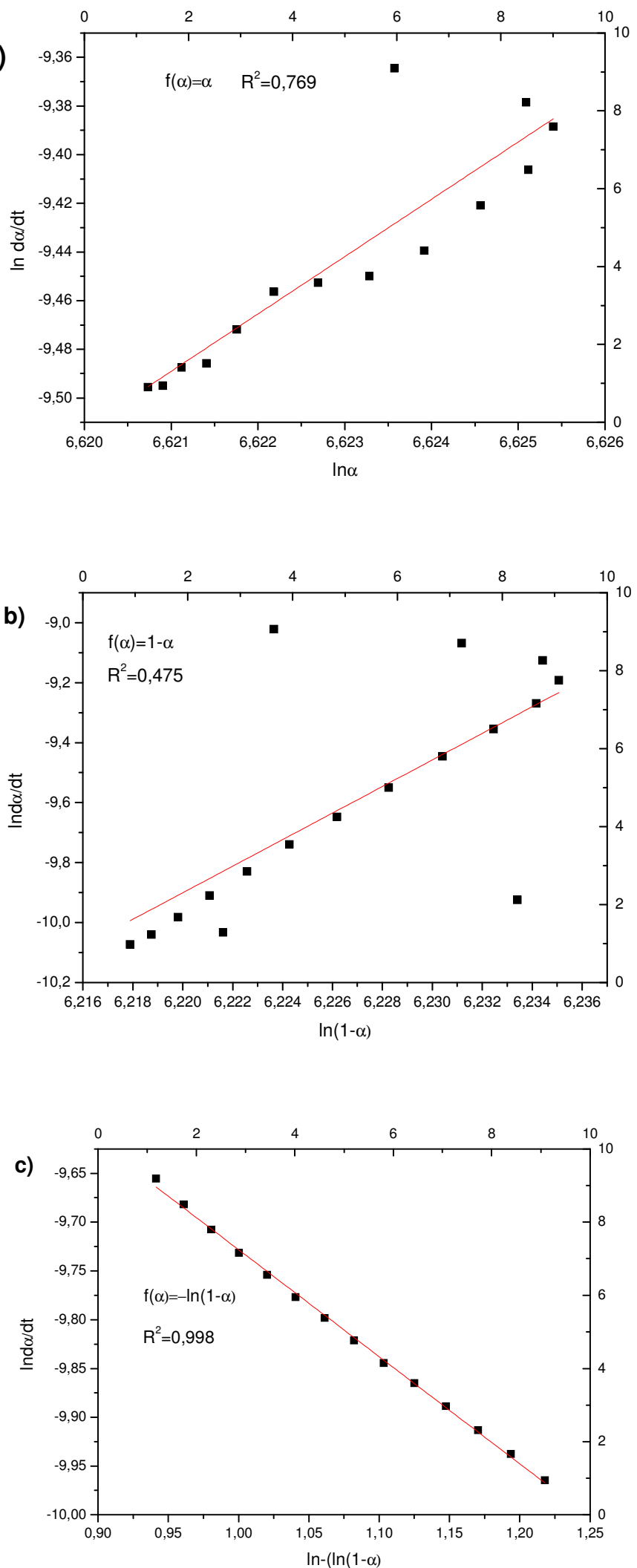

Figura 66: In (d $\alpha / d t)$ em função de $\ln (f(\alpha))$ da pelota do pellet feed $B$ no patamar de $800^{\circ} \mathrm{C}$ para as funções a) $f(\alpha)=\alpha$; b) $f(\alpha)=1-\alpha$ e c) $f(\alpha)=-\ln (1-\alpha)$ 
A Figura 67 mostra os diagramas de Arrhenius das reduções realizadas em atmosferas de $10 \%$ de hidrogênio $+90 \%$ de argônio e $10 \%$ de hidrogênio + 90\% de argônio + monóxido de carbono das pelotas dos pellets feed A, B e C com as respectivas energias de ativação aparente indicadas em cada trecho. Observa-se uma variação nos valores da energia de ativação aparente dos três pellets feed em ambas as atmosferas. Nota-se em todos os diagramas de Arrhenius da Figura 67, que as energias de ativação são maiores para temperaturas mais baixas e diminuem e em seguida em temperaturas intermediárias. Este resultado evidencia a variação da energia de ativação aparente ao longo da redução e em função da temperatura.

O conceito de energia de ativação variável pode ser explorado, conforme Vyazovkin [120]: os dados para reações multietapas, mostram que variações na energia de ativação indicam um sinal da complexidade do processo. A análise da dependência de $E_{a}$ mostra sua utilidade para predizer e explorar os mecanismos de cinética dos processos. Do ponto de vista tradicionalista postula-se que a energia de ativação determinada experimentalmente deve ter um único valor constante, diretamente relacionado com uma barreira de energia, originada de teorias cinéticas simples. Para reações em fase gasosa, os passos individuais podem ser isolados e a sua cinética pode ser medida. Como resultado, a energia de ativação experimental pode ser diretamente ligada à barreira de energia de uma reação. No entanto, o isolamento dos passos individuais geralmente não é possível quando se aplica TG e DSC para estudar os processos que ocorrem nos meios sólidos ou líquidos. Para estes tipos de processos, dois fatores devem ser considerados: a ocorrência simultânea de múltiplos passos de reação e a presença de difusão. A difusão acrescenta um passo adicional para uma reação química. Neste caso, a dependência da taxa global em relação à temperatura é descrito pela taxa efetiva. A Figura 67 mostra Diagrama de Arrhenius da redução com $\mathrm{H}_{2} \mathrm{e}$ $\mathrm{H}_{2}+\mathrm{CO}$ dos pellets feed $\mathrm{A}, \mathrm{B}$ e $\mathrm{C}$. Nestes diagramas os pontos referentes aos dois últimos patamares e ao primeiro patamar não foram considerados para 0 cálculo da $\mathrm{E}_{\mathrm{a}}$. 


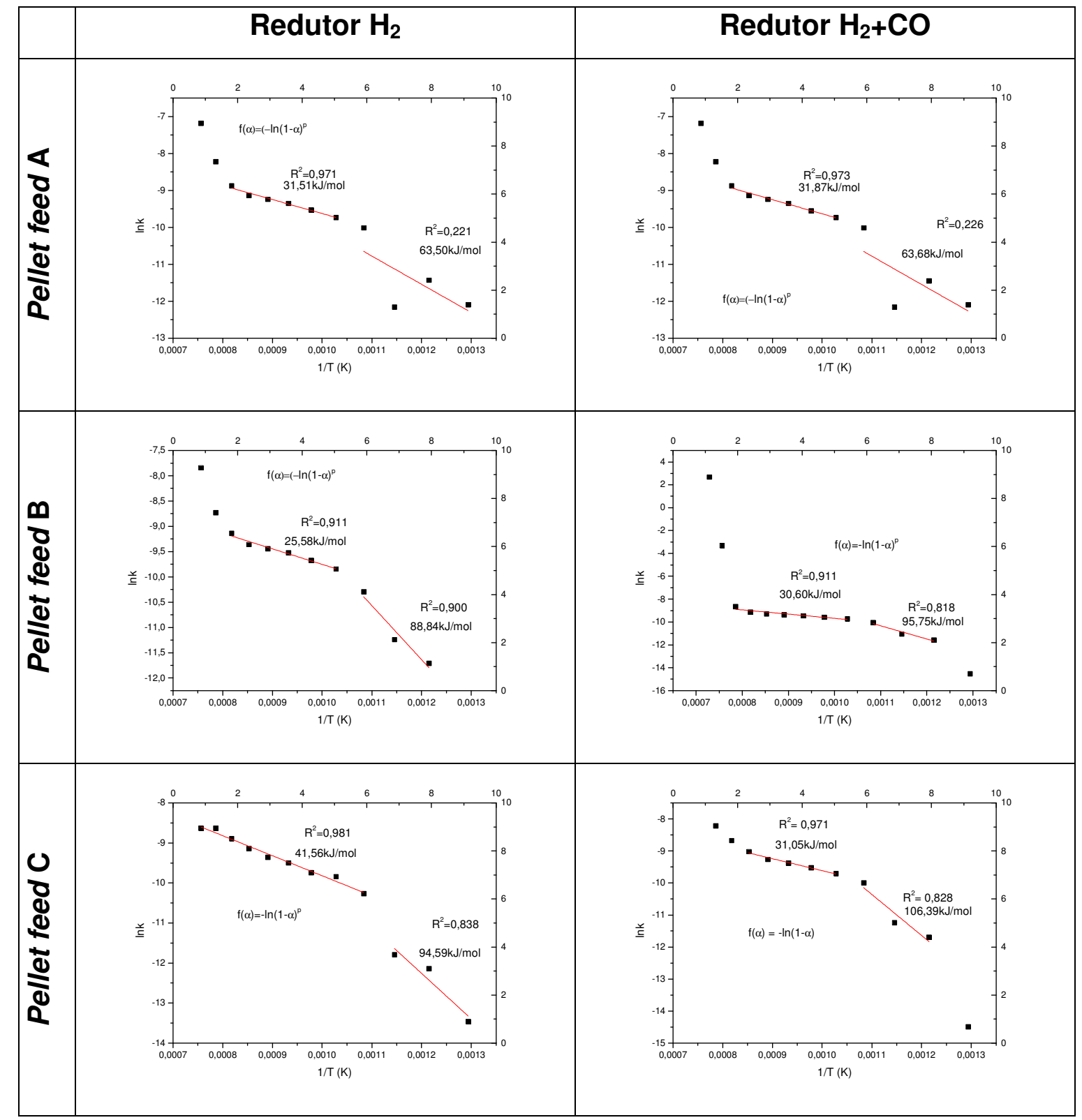

Figura 67: Diagrama de Arrhenius da redução utilizando atmosfera de $\mathrm{H}_{2}(10 \%$ de hidrogênio $+90 \%$ de argônio) e $\mathrm{H}_{2}+\mathrm{CO}((10 \%$ de hidrogênio $+90 \%$ de argônio $)+$ monóxido de carbono)) dos pellets feed $\mathrm{A}, \mathrm{B}$ e $\mathrm{C}$.

As energias de ativação nas duas atmosferas estudadas diferem dos resultados obtidos pelo método Jump. Assim, a equação descritora do mecanismo controlador por difusão considerada por Sestak-Berggren não representa o mecanismo real da redução. Esta equação é válida para o caso genérico e não considera o cenário onde várias formas de difusão estão presentes tanto no estado sólido como no estado gasoso. Ou seja, o processo 
de redução é complexo, cujo mecanismo controlador difusivo está sobreposto a outros tipos, compondo um mecanismo misto.

Para o FSIA o modelo escolhido não se ajusta bem no início da análise até atingir uma estabilização. Outro fator que contribui é a pequena duração das isotermas, devido à imposição da elevada taxa de reação. Neste caso o sistema não consegue atingir uma estabilização na variação de massa. Esta questão é mais relevante em baixas temperaturas, quando as variações de massa são menores, o que pode causar um distanciamento do modelo proposto.

Em um de seus trabalhos, Vyazovkin [120] comenta sobre a variação da energia de ativação, citando os processos controlados por difusão.

A Figura 68 [104] apresenta um diagrama de Arrhenius genérico de um processo envolvendo difusão, onde $E_{R}$ é a energia de reação e $E_{D}$ é a energia de difusão. Nota-se a variação da energia de ativação, resultando em uma diminuição nos valores conforme a reação prossegue. Estes dados corroboram com os resultados encontrados nesta tese. Indicando que a redução direta de pelotas de minérios de ferro em atmosfera de $(10 \%$ de hidrogênio $+90 \%$ de argônio) $\mathrm{H}_{2}$ e ((10\% de hidrogênio $+90 \%$ de argônio)+monóxido de carbono)) $\mathrm{H}_{2}+\mathrm{CO}$, envolve um grau de complexidade e que o mecanismo de difusão está envolvido no processo de redução. Tanto as energias de ativação calculadas pelo método Jump quanto pelo método FSIA apresentaram uma diminuição da energia de ativação conforme o prosseguimento da redução indicando uma mudança no mecanismo controlador. 


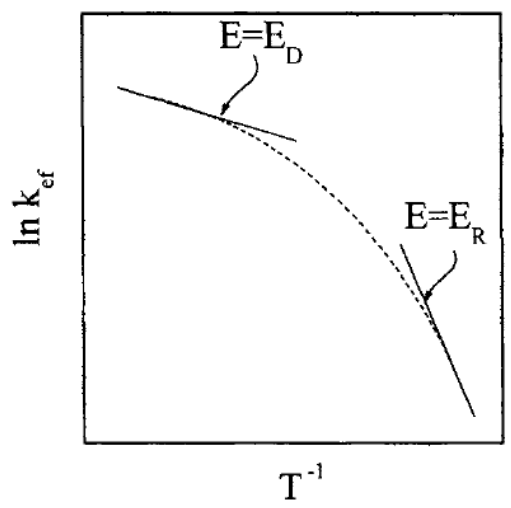

Figura 68: Digragrama de Arrhenius genérico para um processo envolvendo difusão $[104,106]$.

A Tabela 20 mostra alguns valores da energia de ativação aparente encontrados na literatura. Os resultados de $E_{a}$ encontrados neste trabalho utilizando o método FSIA são coerentes com os resultados encontrados na literatura com a utilização de outros métodos. Indicando que o método FSIA aplicado a pelotas de minérios de ferro fornece resultados similares a outros métodos de análise cinética.

Tabela 20: Valores de $E_{a}$ encontrados na literatura.

\begin{tabular}{|c|c|c|c|}
\hline Autor & Etapa da redução & $\begin{array}{c}\mathbf{E}_{\mathbf{a}} \\
\text { (kJ/mol) }\end{array}$ & $\begin{array}{c}\text { Método } \\
\text { experimental }\end{array}$ \\
\hline $\begin{array}{c}\text { Piotrowski et. } \\
\text { al. [121] }\end{array}$ & $\mathrm{Fe}_{2} \mathrm{O}_{3} \rightarrow \mathrm{FeO}\left(\mathrm{H}_{2}\right)$ & 23,86 & Isoterma \\
\hline $\begin{array}{c}\text { Piotrowski et. } \\
\text { al. 121 }\end{array}$ & $\mathrm{Fe}_{2} \mathrm{O}_{3} \rightarrow \mathrm{FeO}(\mathrm{CO})$ & 104,13 & Isoterma \\
\hline $\begin{array}{c}\text { Shimokawabe } \\
\text { et. al. [122] }\end{array}$ & $\mathrm{Fe}_{2} \mathrm{O}_{3} \rightarrow \mathrm{Fe}_{3} \mathrm{O}_{4}$ & $33,29-$ & $\begin{array}{c}\text { Taxa de } \\
\text { aquecimento } \\
\text { linear }\end{array}$ \\
\hline $\begin{array}{c}\text { Sastri et. al. } \\
\text { [123] }\end{array}$ & $\mathrm{Fe}_{2} \mathrm{O}_{3} \rightarrow \mathrm{Fe}$ & $57,02-$ & $\begin{array}{c}\text { Isoterma } \\
73,02\end{array}$ \\
\hline $\begin{array}{c}\text { Tiernam et. al. } \\
\text { [124] }\end{array}$ & $\mathrm{Fe}_{2} \mathrm{O}_{3} \rightarrow \mathrm{Fe}_{3} \mathrm{O}_{4}$ & 106,01 & $\begin{array}{c}\text { Taxa de } \\
\text { aquecimento } \\
\text { linear }\end{array}$ \\
\hline $\begin{array}{c}\text { Tiernam et. al. } \\
\text { [124] }\end{array}$ & $\mathrm{Fe}_{2} \mathrm{O}_{3} \rightarrow \mathrm{Fe}_{3} \mathrm{O}_{4}$ & 96,05 & $\begin{array}{c}\text { Aquecimento } \\
\text { Linear }\end{array}$ \\
\hline
\end{tabular}

Os resultados das energias de ativação aparente encontrados neste trabalho, são coerentes com a literatura. Esta coerência indica que os métodos 
empregados neste trabalho podem fornecer resultados semelhantes aos obtidos por outros métodos. Portanto o método FSIA é um método viável para a análise cinética da redução de pelotas de minérios de ferro.

Ambos os métodos Jump e FSIA fornecem valores de energia de ativação que indicam a existência de dois mecanismos de redução ao longo da faixa de temperatura estudada. Igualmente, a transição de mecanismo ocorre, em todos os casos, em torno de $650-750^{\circ} \mathrm{C}$.

\subsection{Análise microestrutural}

Nesta seção são apresentados e discutidos os resultados da análise microestrutural da superfície das pelotas totalmente reduzidas e das seções das pelotas com diferentes graus de redução

\subsubsection{Superfície das pelotas totalmente reduzidas}

A Figura 69 mostra imagens de MEV da superfície das pelotas dos pellets feed $A, B$ e $C$ após serem totalmente reduzidas com hidrogênio na temperatura de $850{ }^{\circ} \mathrm{C}$ no forno tubular. 

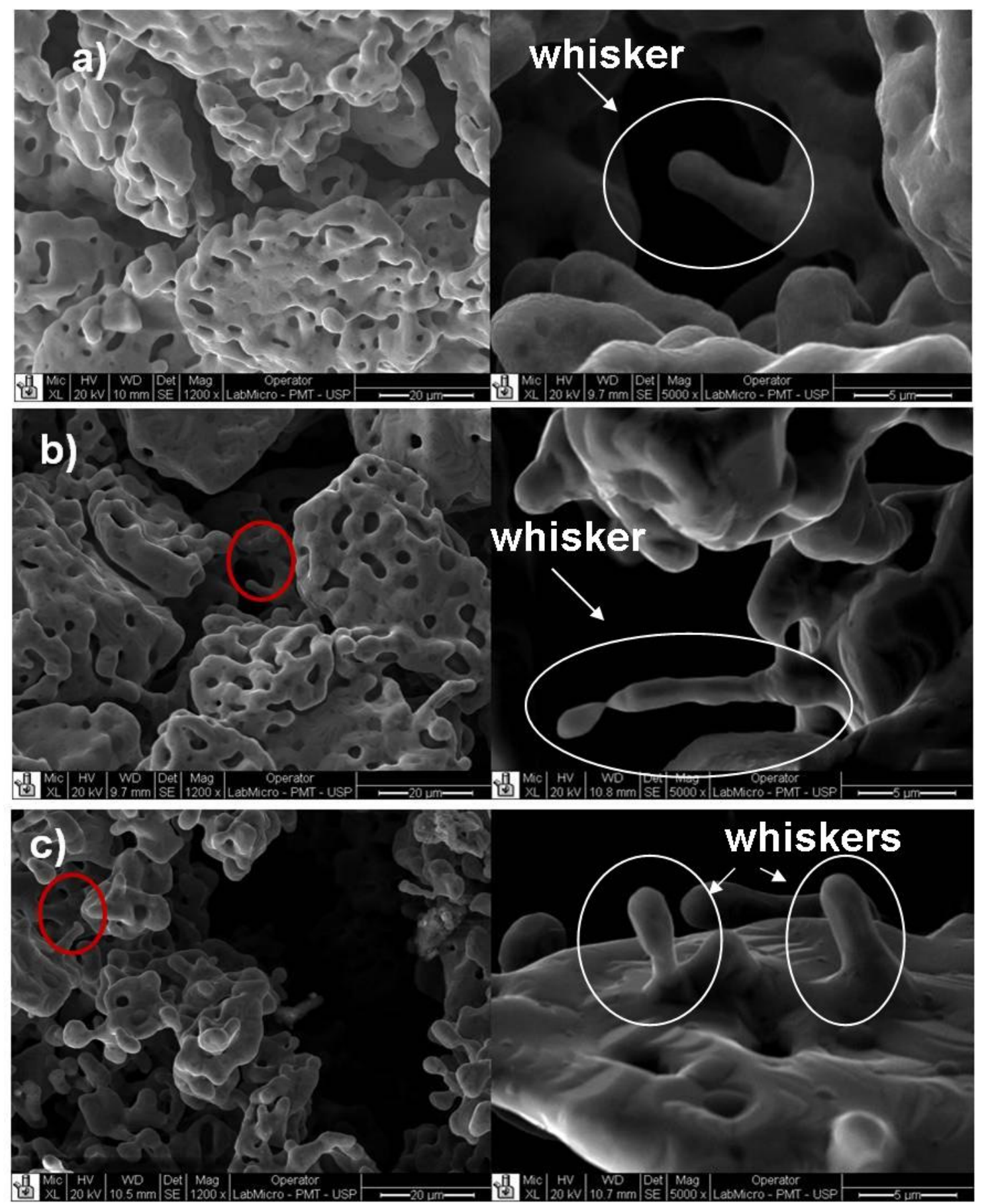

Figura 69: Imagem de MEV no modo elétrons secundários da superfície das pelotas totalmente reduzidas em atmosfera redutora ((10\% de hidrogênio + $90 \%$ de argônio): a) pellet feed $\mathrm{A}$, b) pellet feed $\mathrm{B}$ e c) pellet feed $\mathrm{C}$.

Observa-se, nas imagens da Figura 69, que as partículas que constituem as pelotas mantém suas formas geométricas, mas são porosas e que estes poros são menores que $5 \mu \mathrm{m}$. As pelotas reduzidas dos três pellets feed exibem este aspecto poroso. 
$\mathrm{O}$ aspecto da pelota do pellet feed $\mathrm{C}$ é diferente do aspecto das pelotas dos pellets feed $\mathrm{A}$ e $\mathrm{B}$. Foram observadas mais irregularidades no minério $\mathrm{C}$, este fato pode ser explicado pela distribuição granulométrica deste pellet feed ser diferente em relação aos outros. $\mathrm{O}$ pellet feed $\mathrm{C}$ possui um tamanho médio de partículas menor e uma distribuição de partículas mais dispersa que os pellets feed A e B. As observações das imagens com maiores aumentos sobre a superfície das partículas mostram que existem formações cônicas e em forma de filamentos. Estes filamentos são conhecidos como whiskers. Os filamentos crescem durante a redução. Os filamentos de duas partículas em contato podem crescer e encostarem um no outro formando uma conexão que mantém as duas partículas unidas. O surgimento dos whiskers na superfície das partículas pode levar à aderência de uma partícula à outra e também de uma pelota à outra $[125,126]$. A adesão das partículas pode acarretar em dificuldades na operação contínua de reatores para a redução direta de minérios de ferro.

A Figura 70 mostra imagens de MEV da superfície das pelotas dos pellets feed A, B e C após serem totalmente reduzidas com $((10 \%$ de hidrogênio + 90\% de argônio) + monóxido de carbono) na temperatura de $850{ }^{\circ} \mathrm{C}$. É possível ver que as partículas que constituem as pelotas são porosas e que estes poros são menores que $5 \mu \mathrm{m}$. $O$ aspecto poroso foi observado nas pelotas reduzidas dos três pellets feed. 


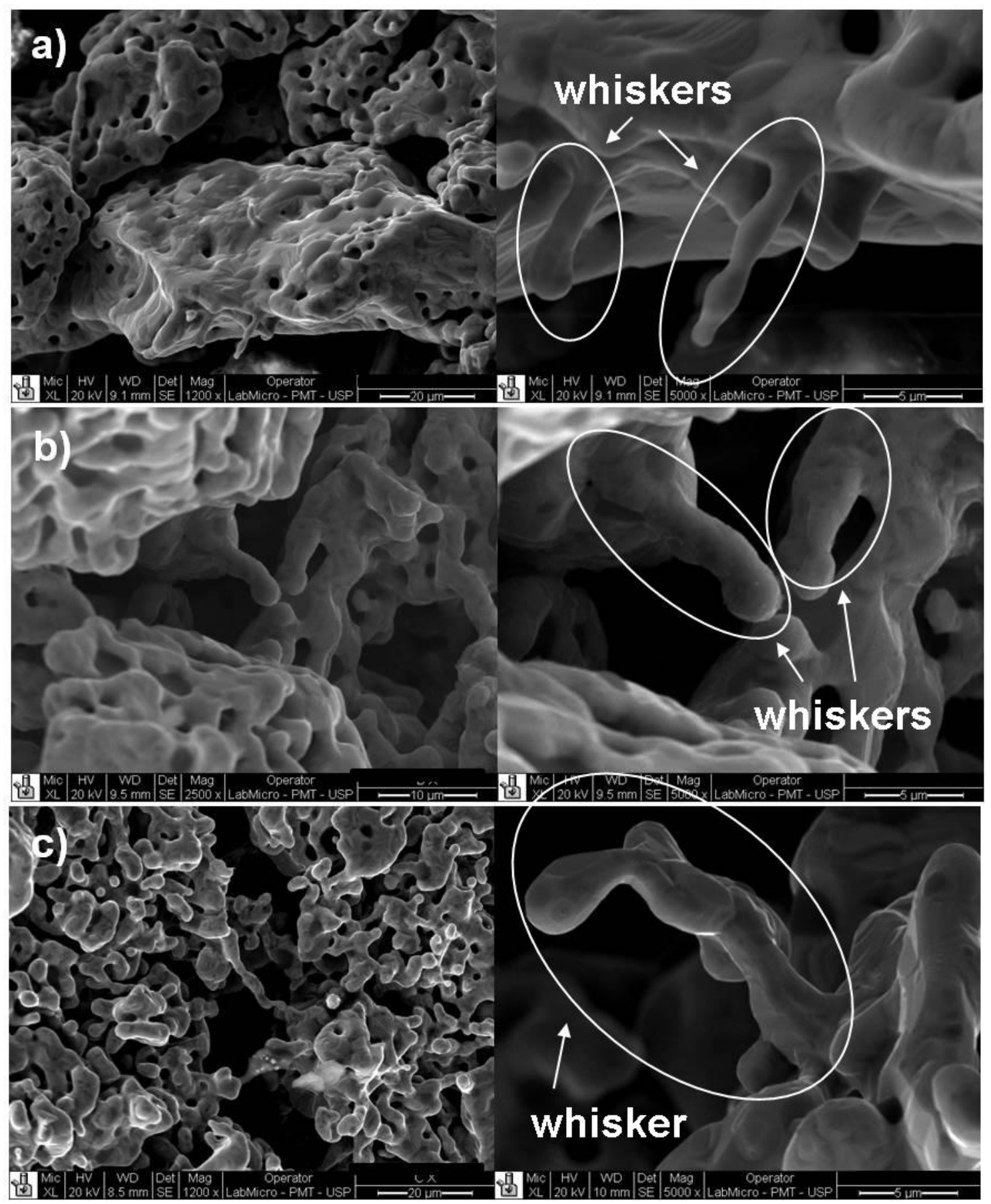

Figura 70: Imagem de MEV no modo elétrons secundários da superfície das pelotas totalmente reduzidas em atmosfera redutora (( $10 \%$ de hidrogênio $+90 \%$ de argônio) + (monóxido de carbono): a) pellet feed $\mathrm{A}, \mathrm{b}$ ) pellet feed $\mathrm{B}$ e c) pellet feed $\mathrm{C}$.

$\mathrm{Na}$ análise comparativa do aspecto das pelotas reduzidas em diferentes atmosferas, nota-se que em atmosfera de hidrogênio o ferro obtido pela redução é mais poroso. Enquanto que em atmosfera ((10\% de hidrogênio + 90\% de argônio) + (monóxido de carbono) é menos poroso e os whiskers aparecem em maior número. Estas observações indicam que o gás de redução 
exerce influência na morfologia final das partículas reduzidas na temperatura ensaiada. Ou seja, existe um indicativo que a presença do $\mathrm{CO}$ no gás de redução faz com que o ferro obtido tenha uma quantidade de poros menor do que o ferro obtido pela redução em atmosfera composta por (10\% de hidrogênio + 90\% de argônio). Também o CO presente no gás de redução propicia o aparecimento dos whiskers. Estas observações em relação à composição do gás redutor concordam com os resultados apresentados e compilados por Lingyun Yi [127] que estudou o efeito da composição do gás, da temperatura e grau de redução.

O surgimento e crescimento dos whiskers tem origem da transformação (redução) da wustita para ferro metálico conforme foi discutido anteriormente na seção sobre as diferentes morfologias que surgem na redução da wustita.

A wustita metaestável é então dividida em ferro metálico e wustita. Após a germinação, o excesso de íons ferrosos na região supersaturada em torno do embrião cria um fluxo de íons de ferro através do volume e na superfície que propiciam o crescimento do germe [38].

O fato de ocorrer um maior número de whiskers e estes whiskers serem maiores na redução com $\mathrm{CO}$ presente no gás de redução é relatado na literatura [125-128] é descrito que a taxa de redução com $\mathrm{H}_{2}$ é mais rápida quando comparada com $\mathrm{CO}$, ou seja, $\mathrm{O}_{2}$ tem o poder de redução maior, com isso a nucleação de ferro ocorre num número muito maior dos sítios e os núcleos logo são combinadas formando um camada porosa de ferro reduzido. Portanto, a presença crescente de $\mathrm{H}_{2}$ causa um aumento do número de sítios nucleantes e a formação de poros.

Para se evitar este fenômeno são citados na literatura algumas indicações, entre elas está o aumento da quantidade de $\mathrm{H}_{2}$ em relação ao CO no gás de redução, diminuição da temperatura de redução [127] e o revestimento de pelotas com material refratário [129]. 


\subsubsection{Seções das pelotas com diferentes graus de redução}

As seções transversais das pelotas dos pellet feed A, B e C parcialmente reduzidas $(25 \%, 50 \%$ e $75 \%$ de redução) com hidrogênio na temperatura de $850^{\circ} \mathrm{C}$ no forno tubular são mostradas na Figura 71 .

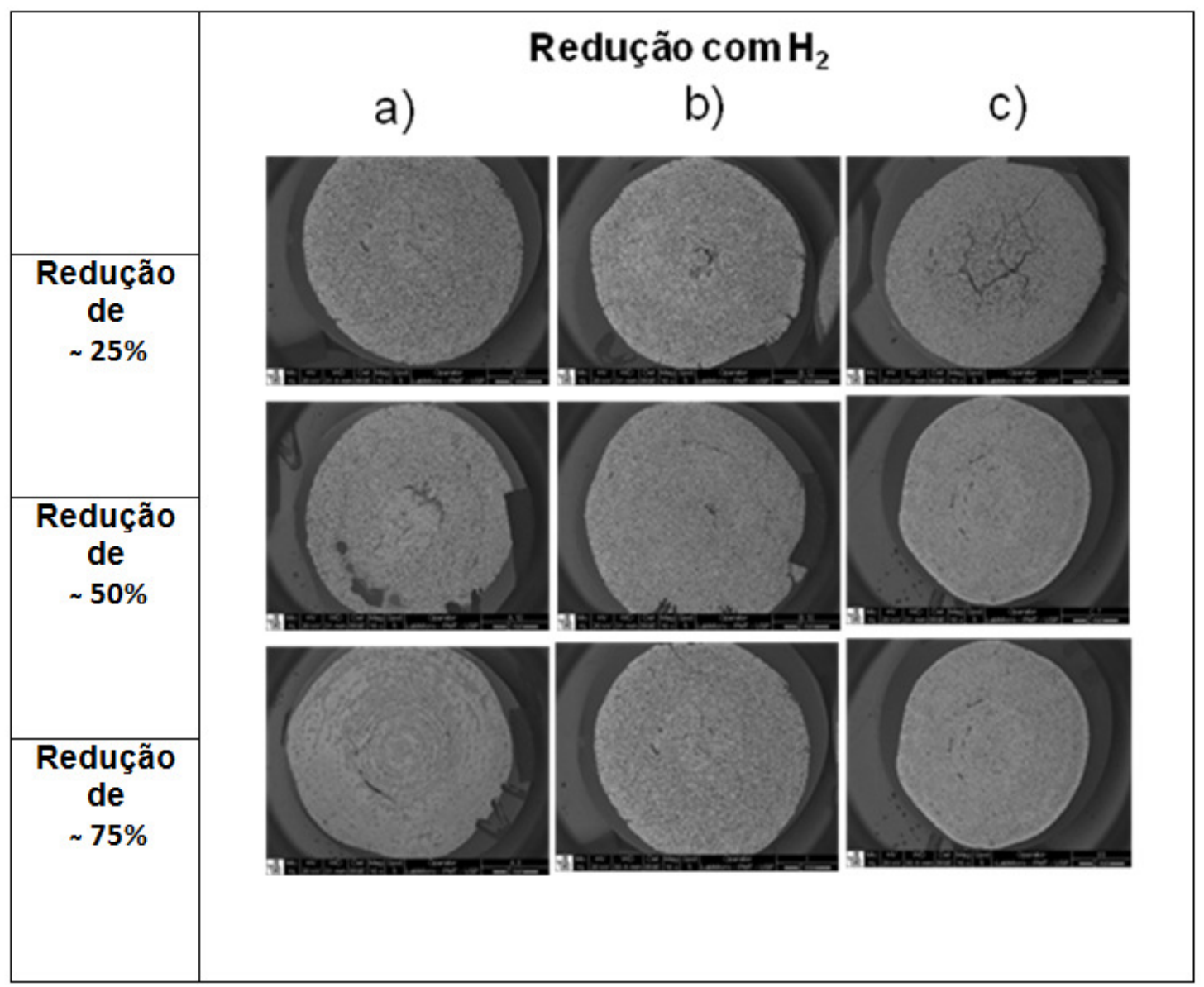

Figura 71: Morfologia da seção das pelotas reduzidas com hidrogênio $\left(H_{2}\right)$ com aproximadamente 25, 50 e 75\% de redução a) pellet feed A, b) pellet feed B e c) pellet feed C.

Na Figura 71 é possível ver alguns defeitos no interior das pelotas. Notam-se também trincas na pelota do pellet feed C com $25 \%$ de redução. Microestruturas semelhantes podem ser observadas nas pelotas com $25 \%$ de redução. As seções das pelotas com $25 \%$ de redução foram observadas com maiores aumentos, afim de se conhecer como se progredia a redução. As Figura 72, 77 e 78 mostram imagens de MEV no modo elétrons retroespalhados e o EDS das diferentes composições químicas das seções das pelotas com $25 \%$ de redução dos pellets feed $\mathrm{A}$, B e C respectivamente. 


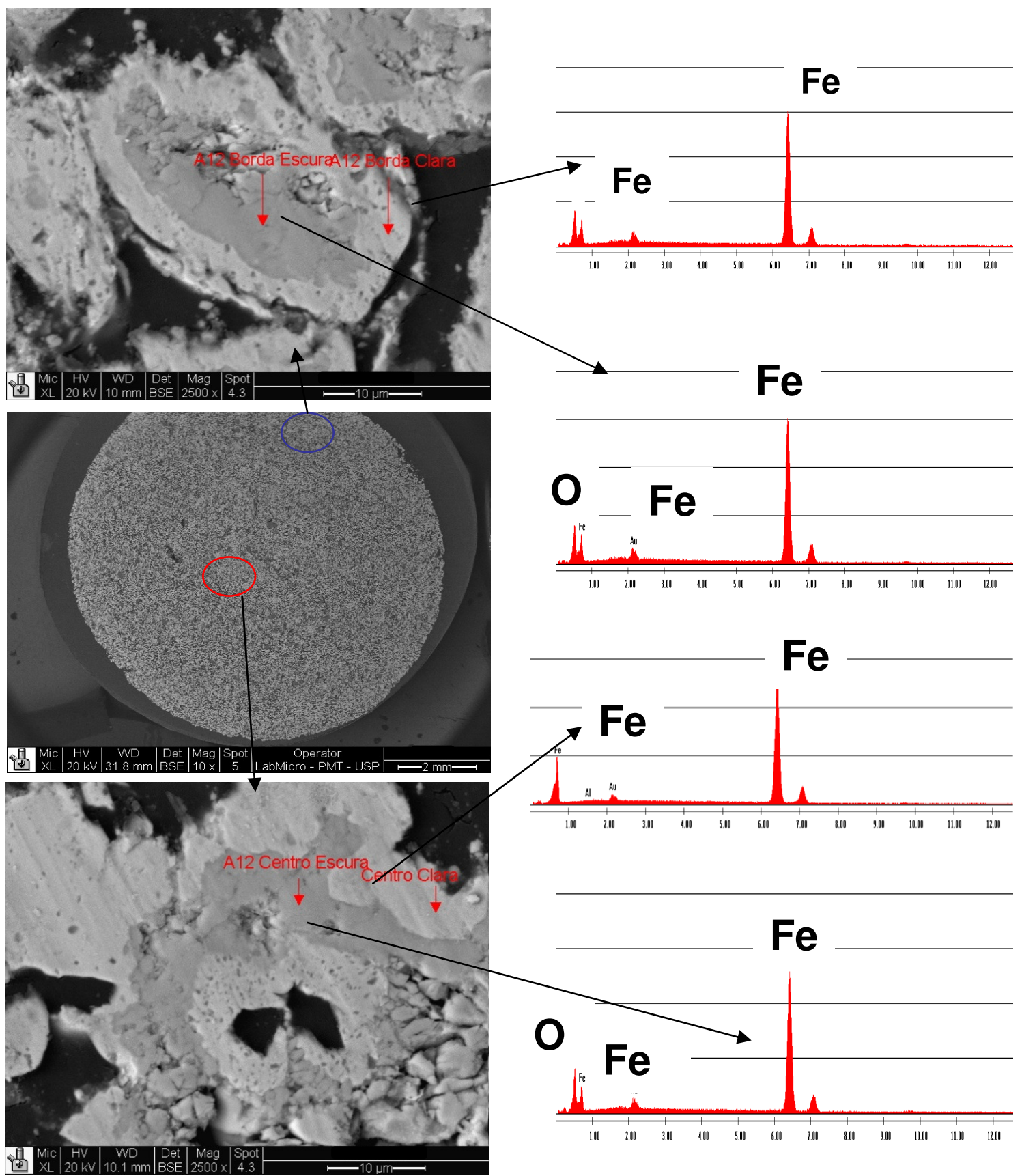

Figura 72: Imagem de MEV no modo elétrons retroespalhados e espectro de EDS da pelota do pellet feed A com aproximadamente $25 \%$ de redução em atmosfera de $\mathrm{H}_{2}+\mathrm{Ar}$ composta por (10\% de hidrogênio + $90 \%$ de argônio).

$\mathrm{Na}$ Figura 72 nota-se que tanto as partículas da borda quando as do centro da pelota sofreram uma redução parcial, isto é evidenciado pela diferença de tonalidade de cinza em cada partícula e fica comprovado pelo espectro de EDS realizado na parte cinza escuro e cinza claro de cada 
partícula. Pelo espectro de EDS nota-se que a parte escura no interior da partícula possui oxigênio enquanto que a parte clara não. Este comportamento foi observado nas pelotas dos pellet feed A, B e C

A Figura 73 mostra a imagem de MEV juntamente com o espectro EDS das respectivas regiões conforme indicado na imagem das seções da pelota do pellet feed B com aproximadamente $25 \%$ de redução. Uma imagem extra foi inserida na Figura mostrando que as partículas vizinhas exibiam o mesmo perfil de imagem, composta por parte mais escura ao centro e a periferia mais clara. 


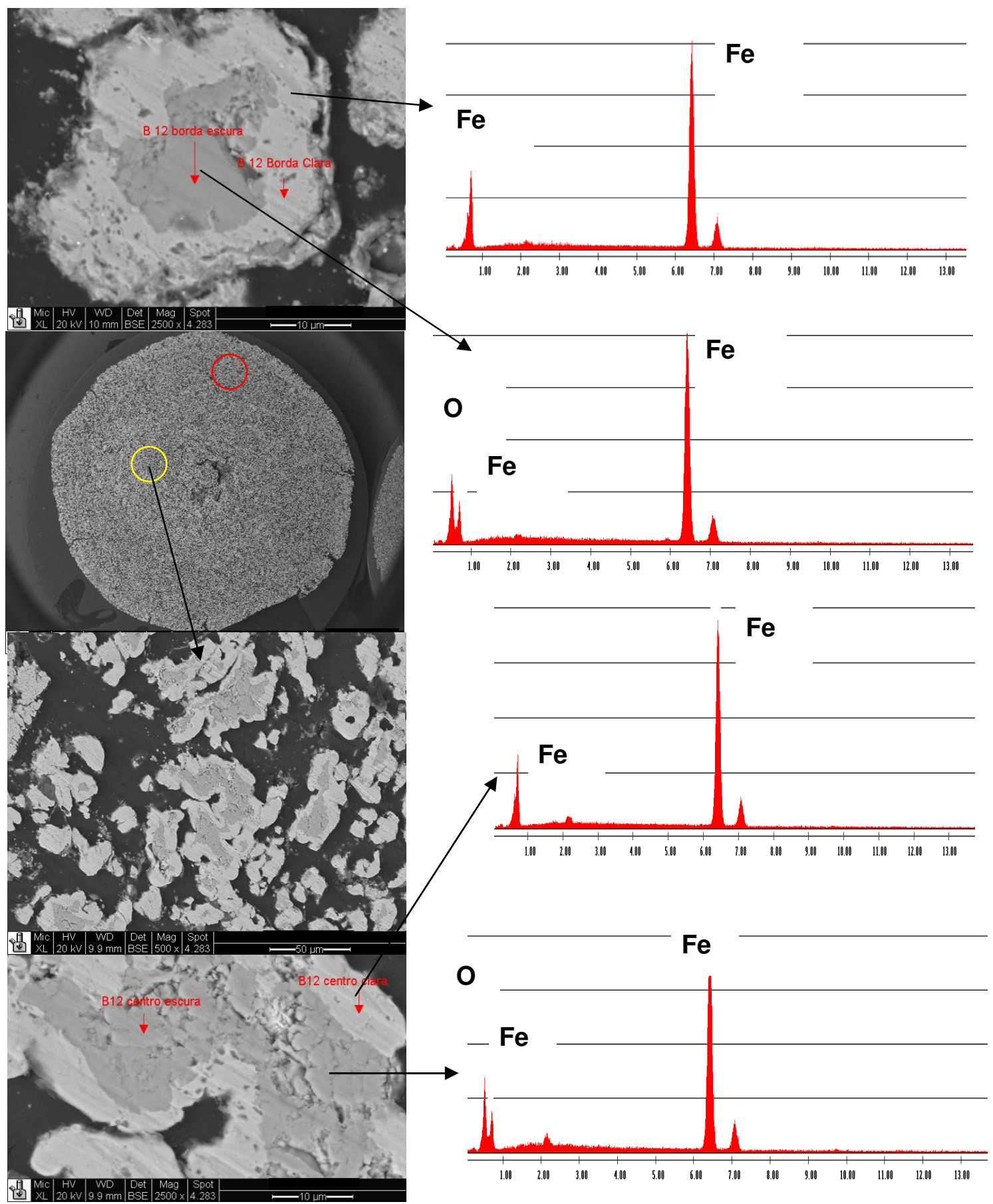

Figura 73: Imagem de MEV no modo elétrons retroespalhados e espectro de EDS da pelota do pellet feed $\mathrm{B}$ com aproximadamente $25 \%$ de redução em atmosfera de $\mathrm{H}_{2}+\mathrm{Ar}$ composta por (10\% de hidrogênio + $90 \%$ de argônio).

A Figura 74 mostra a imagem de MEV juntamente com o espectro de EDS das respectivas regiões conforme indicado na imagem das seções da pelota do pellet feed C com aproximadamente $25 \%$ de redução. 

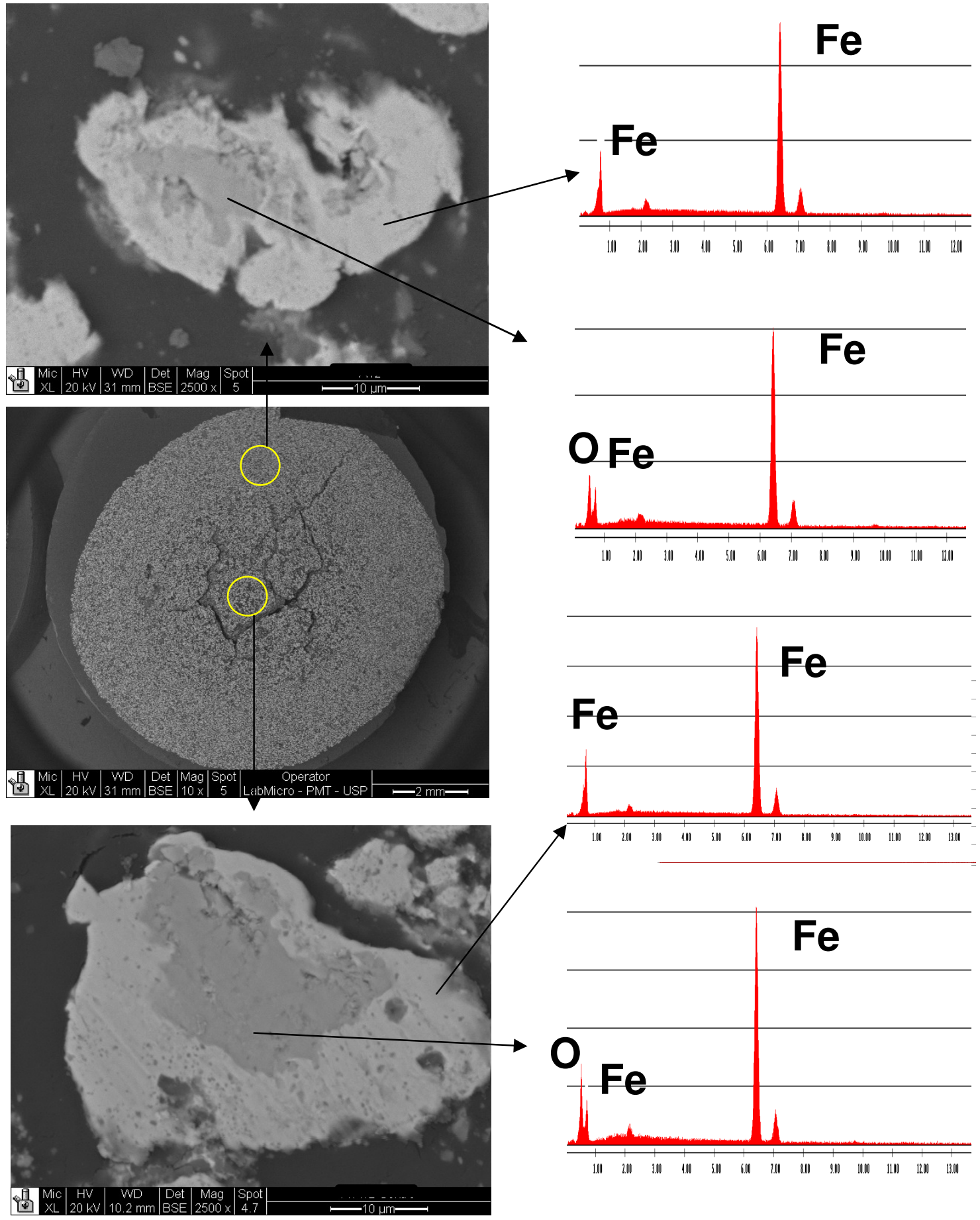

Figura 74: Imagem de MEV no modo elétrons retroespalhados e espectro EDS da pelota do pellet feed $\mathrm{C}$ com aproximadamente $25 \%$ de redução em atmosfera de $\mathrm{H}_{2}+\mathrm{Ar}$ composta por (10\% de hidrogênio + $90 \%$ de argônio)..

Os resultados da morfologia das seções das pelotas dos pellets feed A, B e C com $25 \%$ de redução em atmosfera de hidrogênio mostraram que a redução ocorre nas partículas da periferia e do interior da pelota ao mesmo 
tempo. Estes resultados indicam que a redução ocorre da forma uniforme ou seja todas as partículas que compõem as pelotas são reduzidas ao mesmo tempo.

As seções transversais das pelotas dos pellets feed $A, B$ e $\mathrm{C}$ parcialmente reduzidas $(25 \%, 50 \%$ e $75 \%$ de redução) com hidrogênio + monóxido de carbono na temperatura de $850^{\circ} \mathrm{C}$ são mostradas na Figura 75 .

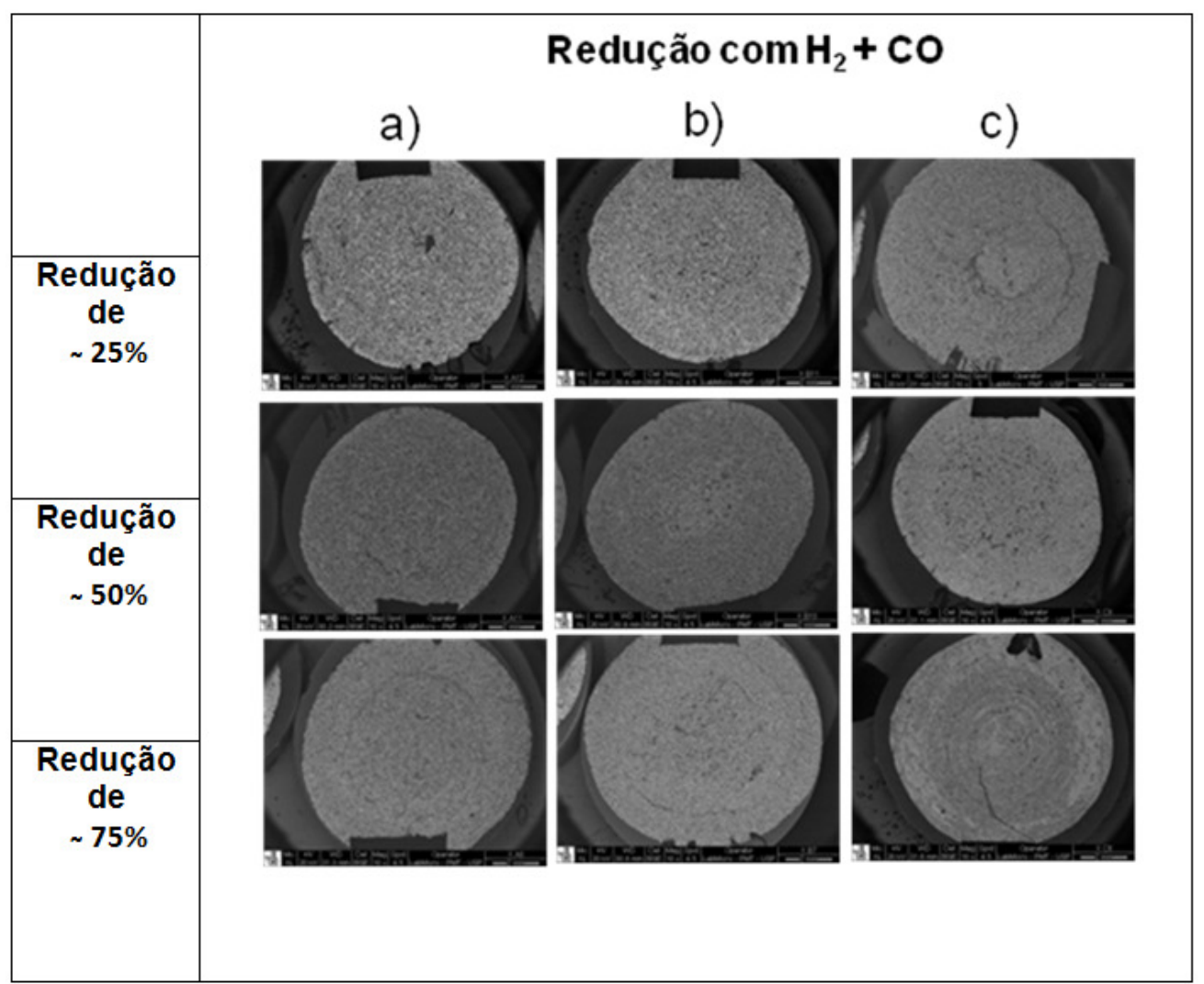

Figura 75: Morfologia da seção das pelotas reduzidas com (10\% de hidrogênio + argônio) + monóxido de carbono) com aproximadamente 25, 50 e 75\% de redução a) pellet feed $\mathrm{A}, \mathrm{b}$ ) pellet feed $\mathrm{B}$ e c) pellet feed $\mathrm{C}$.

É possível ver alguns defeitos no interior das pelotas. Microestruturas semelhantes são observadas nas pelotas com $25 \%$ de redução. As seções das pelotas com $25 \%$ de redução foram observadas com maiores aumentos, afim de se conhecer como se progredia a redução. As Figura 76, Figura 77, Figura 78 mostram imagens de MEV e os seus respectivos espectros de EDS das diferentes composições químicas das seções das pelotas com $25 \%$ de redução conforme indicado em cada figura dos pellet feed $\mathrm{A}, \mathrm{B}$ e $\mathrm{C}$ respectivamente. 


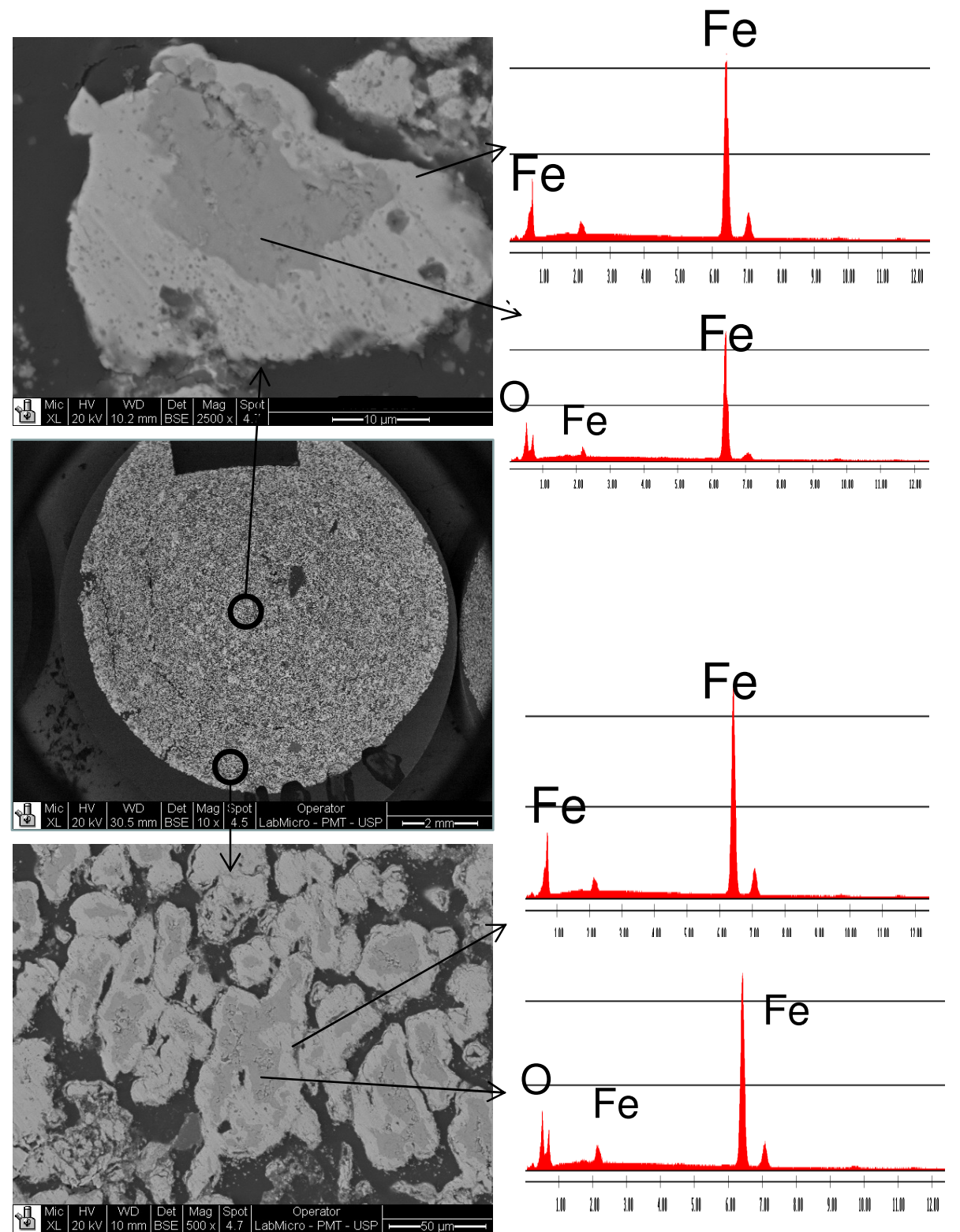

Figura 76: Imagem de MEV no modo elétrons retroespalhados e espectro de EDS da pelota do pellet feed A com aproximadamente $25 \%$ de redução em atmosfera $\mathrm{H}_{2}+\mathrm{Ar}+\mathrm{CO}$ composta por ((10\% de hidrogênio + 90\% de argônio) + (monóxido de carbono)). 

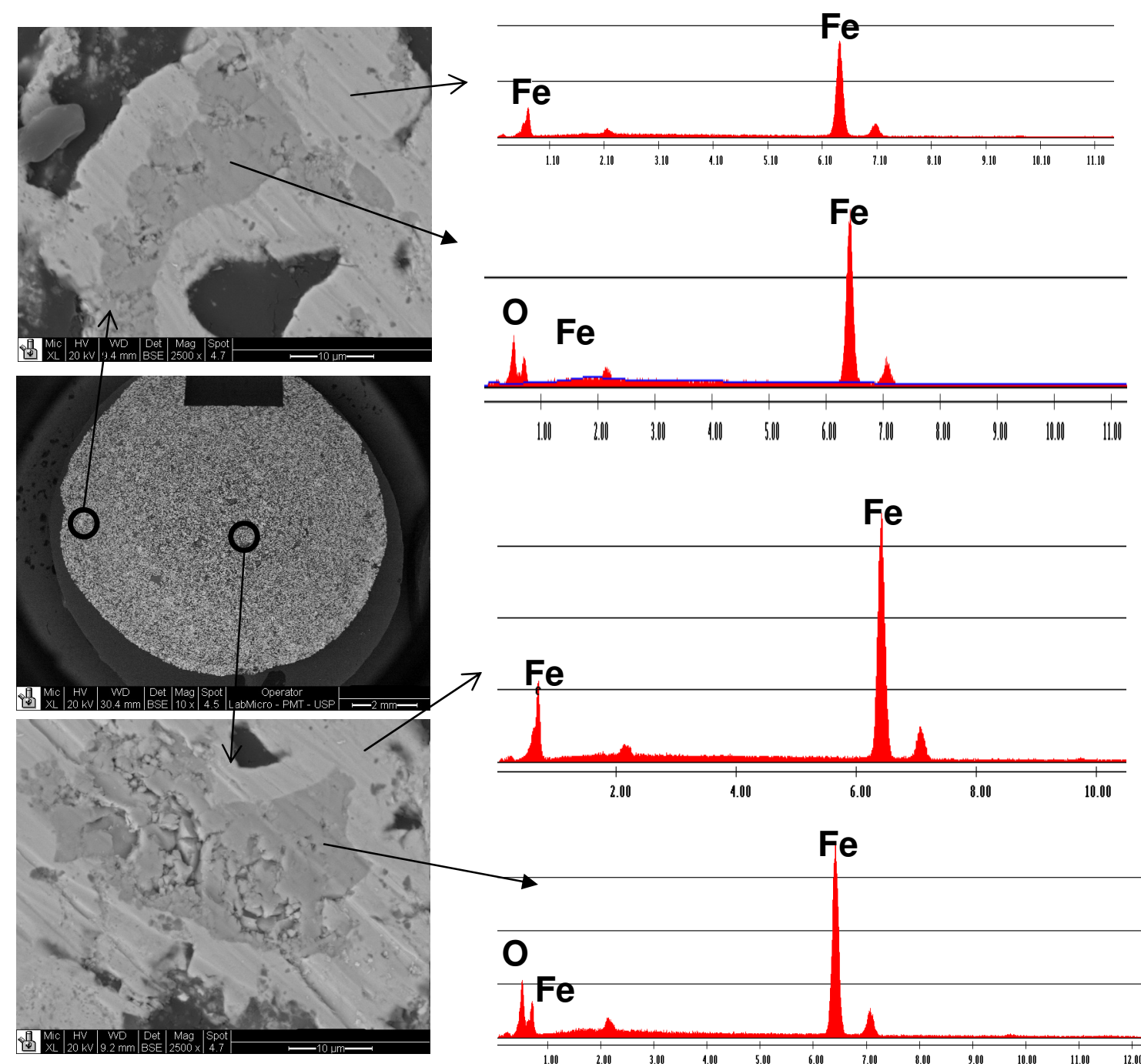

Figura 77: Imagem de MEV no modo elétrons retroespalhados e espectro de EDS da pelota do pellet feed B com aproximadamente $25 \%$ de redução em atmosfera de $\mathrm{H}_{2}+\mathrm{Ar}+\mathrm{CO}$ composta por ((10\% de hidrogênio + 90\% de argônio) + (monóxido de carbono)). 

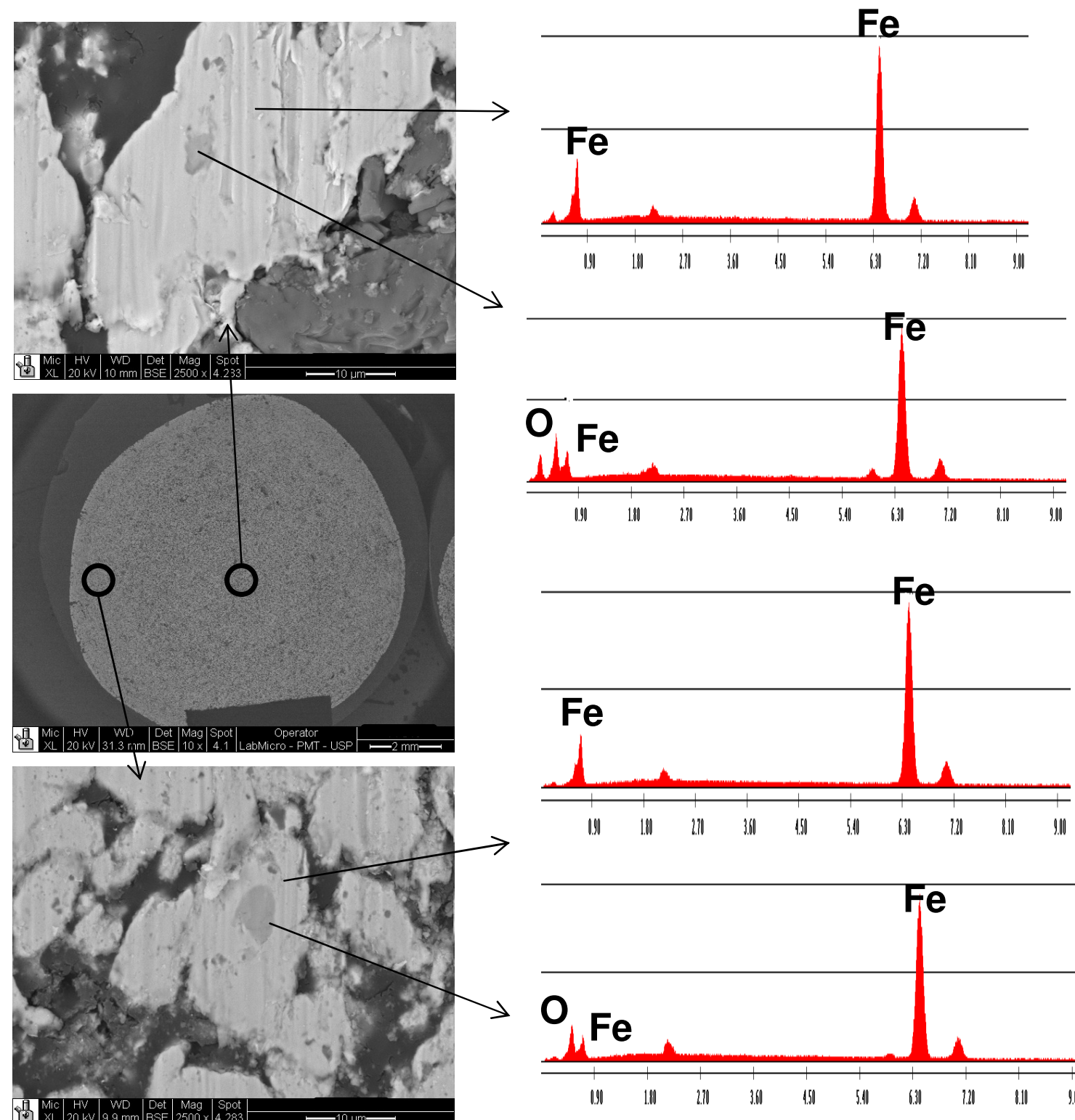

Figura 78: Imagem de MEV no modo elétrons retroespalhados e espectro de EDS da pelota do pellet feed $\mathrm{C}$ com aproximadamente $25 \%$ de redução em atmosfera de $\mathrm{H}_{2}+\mathrm{Ar}+\mathrm{CO}$ composta por $((10 \%$ de hidrogênio $+90 \%$ de argônio) + (monóxido de carbono)).

Os resultados da morfologia das seções das pelotas dos pellets feed A, B e C com 25\% de redução em atmosfera de hidrogênio + monóxido de carbono mostraram que a redução ocorre nas partículas da periferia e do interior da pelota ao mesmo tempo. Estes resultados indicam que a redução ocorre da forma uniforme ou seja todas as partículas que compõem as pelotas são reduzidas ao mesmo tempo. 
A morfologia das seções das pelotas com $25 \%$ de redução utilizando como gás redutor o hidrogênio e hidrogênio + monóxido de carbono são semelhantes. Estes resultados são semelhantes também aos resultados encontrados por Sohn e Fruehan [130] que descrevem a existência de uma região com oxigênio no interior das partículas e uma região sem oxigênio na borda das partículas.

Em todas as seções observadas com aproximadamente $25 \%$ de redução em diferentes atmosferas redutora, uma camada rica em ferro e pobre em oxigênio quando comparada com o núcleo é formada em cada partícula que compõe a pelota.

É relatado a formação da camada de ferro a partir da superfície externa da pelota e também a redução interna uniforme das partículas que compõem a pelota [13, 38, 42, 78]. O tipo de morfologia formada pode depender do tipo de minério e tamanho de partículas, porosidade das pelotas.

Conforme Turkdogan, esse tipo de morfologia observado com estas pelotas são características de uma redução interna uniforme. Em uma redução interna uniforme de pelotas, a difusão dos gases nos poros da pelota é rápida permitindo que a reação ocorra em todas as partículas, as mais internas e as mais externas, que constituem a pelota.

A morfologia observada em cada partícula, as da borda e as do interior da pelota, exibem o mesmo perfil, ou seja a periferia da partícula sem oxigênio e o interior (núcleo da partícula) com oxigênio.

Conforme Sohn e Fruehan, a redução envolve mecanismos complexos sendo que o controle da redução pode ser feito pela cinética química na interface que vai se dirigindo para o interior da partícula e pela transferência de massa na camada que foi reduzida [130].

Os resultados da análise da morfologia e da análise cinética corroboram entre si. Sugerem que a redução é controlada por um processo misto, envolvendo reação química e transferência de massa (difusão), sendo que a difusão exerce um papel mais dominante na cinética de redução. 


\section{Conclusões}

Dentro do que foi proposto, sobre a investigação da redução direta de pelotas de minério de ferro, foi realizado experimentalmente a redução direta de pelotas de três tipos de pellets feed com hidrogênio e hidrogênio mais monóxido de carbono. Com os resultados e a investigação bibliográfica realizados neste trabalho foram identificadas as características do processo de redução direta de minério de ferro por hidrogênio e hidrogênio mais monóxido de carbono.

1. O aumento da temperatura de redução acarreta uma maior degradação física das pelotas, ocorrendo o surgimento de trincas e causando a desintegração. O mesmo se observou quando o fluxo gasoso foi aumentado durante a redução na termobalança.

2. Foi observada a formação de whiskers na superfície externa das pelotas, sendo estes mais freqüentes quando do fluxo combinado de $\mathrm{H}_{2}+\mathrm{CO}$. Por outro lado as pelotas reduzidas por hidrogênio puro resultou em maior porosidade tanto no corpo da pelota ou mesmo no interior das partículas.

3. A estrutura de poros das pelotas assegura a redução homogênea em todas as partículas componentes, conforme demonstrado nas análises por MEV com elétrons retroespalhaddos associado ao espectro de EDS pontual.

4. O estudo cinético através dos métodos combinados Jump-FSIA demonstrou ser aplicável na redução direta de pelotas de minério de ferro por $\mathrm{H}_{2}$ e $\mathrm{H}_{2}+\mathrm{CO}$, permitindo inferir os mecanismos controladores e as temperaturas de mudança de mecanismo.

5. Para pelotas conformadas a partir de pellet feed com maior área de superfície específica (mais ativas), tanto a cinética quanto a 
taxa de redução indicaram que a adição de $\mathrm{CO}$ ao gás redutor não influi no processo de redução.

6. A teoria de Sestak-Berggren sugere que o mecanismo controlador na reação global é a difusão. Entretanto, os resultados demonstram que o mecanismo de difusão é complexo e pode estar aliado a outras etapas, compondo um mecanismo misto.

7. Os resultados sujerem que a difusão de íons no estado sólido ao longo das camadas reagidas consiste na etapa controladora, uma vez que a pelota mais ativa com menor porosidade total apresentou maior taxa de redução. Sendo assim, a influência da difusão do gás de redução é menos importante que a reatividade das partículas. 


\section{Referências Bibliográficas}

[1] Kyoto Protocol to the United Nations Framework. Convention on Climate Change. United Nations, 1998. Disponível em <http://unfccc.int/resource/docs/convkp/kpeng.pdf> Acesso em 03/03/2010.

[2] Arrhenius, S. A. On the Influence of Carbonic Acid in the Air upon the Temperature of the Ground. Philosophical Magazine and Journal of Science S. 5, v. 41, p. 237-276, abril 1896.

[3] Pielke Jr. R; Wigley, T; Green, C. Dangerous assumptions. How big is the energy challenge of climate change? The technological advances needed to stabilize carbondioxide emissions may be greater than we think. Nature, v. 453 p. 531-532, abril 2008.

[4] Friedlingstein, P. A steep road to climate stabilization. Nature, v. 451, p. 297-298, janeiro 2008.

[5] Birat, J. P; Hanrot, F; Danloy, G. $\mathrm{CO}_{2}$ Mitigation Technologies in the Steel Industry: A Benchmarking Study Based on Process Calculations. Paper presented at the 3rd International Conference on Science and Technology of Ironmaking on the occasion of the Metec 18 june 2003 in Düsseldorf.

[6] Fruehan, R.J. Research on sustainable steelmaking. Metallurgical and Materials Transactions B, v. 40b, p. 123-133, abril 2009.

[7] Fruehan, R.J. Future Steelmaking Technologies and the Role of Basic Research. Metallurgical and Materials Transactions A, v. 28A, p. 1963-1973, outubro 1997.

[8] Chan, D. Y; Yang, K; Lee, J; Hong, G. The case study of furnace use and energy conservation in iron and steel industry. Energy, v. 35, p. 1665-1670, 2010. 
[9] Course50. Disponível em: http://www.jisf.or.jp/course50/index_en.html. Acesso em 03/10/2011.

[10] ULCOS. Disponível em: http://www.ulcos.org/en/about_ulcos/home.php. Acesso em 03/10/2011

Disponível

em: http://www.steel.org/en/Making\%20Steel/Research\%20and\%20Development.as px. Acesso em 03/10/2011.

[12] The annual IISI publication World Steel in Figures, 2007, http:/worldsteel.org.

[13] Handbook of extractive metallurgy / editado por Fathi Habashi. Weinheim; New York; Chichester; Brisbane; Singapore; Toronto: Wiley-VCH. Volume 1. The metal industry, ferrous metals. p. 29-401, 1997.

[14] Gross, G. A; Kirkham,k R. V; Sinclair, W. D; Thorpe, F. I; Duke, J. M. Industrial and genetic models for iron ore in Iron Formations, In: (eds.) - Mineral Deposit Modeling: Geological Association of Canada, v. 40, p. 151$170,1993$.

[15] Takehara, L. Classificação Geometálurgica dos Principais Minérios de Ferro Brasileiros - Fração Sinter Feed. Instituto de Geociências. Universidade Federal do Rio Grande do Sul. Tese de Doutorado, p. 29-34 2004.

[16] Mineralogy Database disponível em: http://www.webmineral.com/ Acesso em 13/10/2011.

[17] Amorin, C. C. Utilização de Resíduo do Desempoeiramento do Alto Forno para Tratamento de Efluentes. Escola de Engenharia. Universidade Federal de Minas Gerais. Tese de Doutorado, p. 6-11, 2010. 
[18] Cornell, R. M; Schwertmann, U. The Iron Oxides. Weinheim; New York; Cambridge; Tokyo: VCH, p. 26-33,1996.

[19] Poveromo, J. J; Iron Ores. In: The Aise Steel Foundation. (Ed.) Ironmaking , v.8, Pittsburgh, p. 547-550, 1999.

[20] Magalhães, F; Síntese e Caracterização de Óxidos de Ferro e Compósitos para Aplicações no Tratamento Redox de efluentes Aquosos. Departamento de Química. Belo Horizonte, Universidade Federal de Minas Gerais. Tese de Doutorado, p. 45-56, 2008.

[21] Damasceno, E. C; Disponibilidade, suprimento e demanda de minérios para metalurgia. Rio de Janeiro: cetem/mct, p. 22-32, 2007.

[22]

Disponível

em: http://minerals.er.usgs.gov/minerals/pubs/commodity/iron_ore/. Acesso em $12 / 07 / 2011$.

[23] Fuel Cell and Hydrogen Energy Association. Disponível em: http://www.fchea.org/index.php?id=46. Acesso em 04/10/2011.

[24] J. O. Edström, Iron Steel Ins, V.75, p. 289-304, 1953.

[25] Plant dana submitted for Midrex Melting Seminar, Tuscaloosa, AL, USA. maio 2000.

[26]Hornby-Anderson, S; Kopfle, J. G; Metins, M. Shimizu Green Steelmaking with MIDREX and FASTMET, The Conference "Abatement and Treatment", Toronto, Canada, p. 26-29 agosto, 2001.

[27] Midrex Technologies Inc. "IBH HBI DRI Melting Seminar", held in conjuction with 30th SEASI, Conference, Singapura, maio 2001. 
28 Birat, J. Hanrot, F. Danloy, G. $\mathrm{CO}_{2}$ mitigation technologies in the steel industry: a benchmarking study based on process calculations. Stahl Und Eisen, v. 123, Nr. 9, p. 69-72, 2003.

[29] Anameric, B; Kawatra, S. K. Properties and Features of Direct Reduced Iron. Mineral Processing \& Extractive Metall, v. 28, p. 59-116, 2007.

[30] Yuan, B., Kongstein, O. E., Haarberg, G. M. Electrowinning of Iron in Aqueous Alkaline Solution Using a Rotating Cathode. Journal of The Electrochemical Society, v.156, p. D64-D69, 2009.

[31] Mourão, M. B. Introdução a Siderurgia. Capítulo 3, Redução de Minério de Ferro em Altos-Fornos. Eduardo Emery C. Quites. P. 55-102.

[32] Turkdogan, E. Blast furnace reactions. Metallurgical and Materials Transactions B. V.9, p. 163-179, 1978.

[33] Turkdogan, E. T; Kor, G. J. W; Fruehan, R. J. Studies of blast-furnace reactions. Ironmaking e Steelmaking, v.7, n.6, p. 268-280, 1980.

Steel

University

disponível

em: http://www.steeluniversity.org/content/html/eng/default.asp?catid=13\&pageid=2 081272285 acesso em: 02/10/2011.

[35] David, S. F. Uma Análise Sobre a Injeção de Carvão Pulverizado no Alto-Forno 1 da Arcelormittal Tubarão Por Meio do Diagrama de Rist. Monografia (Graduação) - Instituto Federal do Espírito Santo, Coordenadoria do Curso de Metalurgia, Curso de Engenharia Metalúrgica, 2010.

[36] American Iron and Steel Institute. Making Steel. How Steel is Made. Disponível em: http://www.steel.org/Making\%20Steel/How\%20lts\%20Made.aspx. Acesso em 22/09/2011. 
[37] Lüngen HB. State of the art and future of the blast-furnace. In: IPIS meeting. Berlin. Setembro 2001.

[38] Wagner, D; Devisme, O; Patisson, F; Ablitzer, D. A Laboratory Study of The Reduction of Iron Oxides by Hydrogen. Sohn International Symposium, San Diego 27-31 agosto 2006.

[39] Pang, J. Guo, P., Zhao, P., Cao, C., Zhao, D., Wang, D. Reduction of 1-3 $\mathrm{mm}$ iron ore by $\mathrm{H}_{2}$ in a fluidized bed. International Journal of Minerals, Metallurgy and Materials, v. 16, ㄲo. 6, p. 629-632 Dezembro 2009.

[40] Pourghahramani, P; Forssberg, E. Reduction Kinetics of Mechanically Activated Hematite Concentrate With Hydrogen Gas Using Nonisothermal Methods. Thermochimica Acta, v. 454, p. 69-77, 2007.

[41] Bogdandy, L. V; Engell, H. J. The Reduction of Iron Ores, SpringerVerlag, p. 47-100 e 230-357, 1971.

[42] Feinman, J. Direct Reduction and Smelting Processes. In: Wakelin, D. $\mathrm{H}$. The making, shaping and treating of steel. $11^{\underline{a}}$ ed. Pittsburgh: The Aise Steel Foundation. Cap. 11, p.763-801, 1999.

[43] Cheeley, R. Gasification and the Midrex direct Reduction Process. In: Gasification Technologies Conference. San Francisco. Artigo. Califórnia, $1999 . \quad$ Disponível em <http://www.gasification.org/Docs/Conferences/1999/GTC99260.pdf> Acesso em 23/03/2010.

[44] Silva, A. C. Simulação computacional da redução direta de minério de ferro em fornos MIDREX. Tese (Doutorado) - REDEMAT, Universidade Federal de Ouro Preto, Ouro Preto, p. 24, 2010. 
[45] MIDREX 2008. World Direct Reduction Statistics. Disponível em $<$ http://www.acobrasil.org.br/ > Acesso em 08/04/2010.

[46] Noldin Júnior, J. H., Contrucci, M. de A., D’Abreu, J. C. Tecnored Process High Potential in Using Different Kinds of Solid Fuels. Materials Research, v. 8, No. 4, p. 447-451, 2005.

[47] D’Abreu, J. C; Kohler, H. M; Noldin Junior, J. H; Costa, P. H. C; Marcheze, E. S; Jacomini, N. Modelamento Matemático da Cuba Superior do Forno Tecnored. Tecnologia em Metalurgia e Materiais, São Paulo, v.4, n.3, p. 6973 jan.-mar. 2008.

[48] Noldin Júnior, J. H; D’Abreu, J. C; Marcheze, E. S; Costa, P. H. C. Flexibilidade de Matérias-Primas no Processo Tecnored. Tecnologia em Metalurgia e Materiais, São Paulo, v.3, n.3, p. 22-27, jan.-mar. 2007.

[49] Noldin Jr., J. H.; Modelo termoquímico da auto-redução em fornos de cuba. Departamento de Ciência dos Materiais e Metalurgia, Pontifícia Universidade Católica do Rio de Janeiro. Rio de Janeiro, Tese de Doutorado , p. $61,2007$.

[50] Yuan, B., Kongstein, O. E., Haarberg, G. M. Electrowinning of Iron in Aqueous Alkaline Solution Using a Rotating Cathode. Journal of The Electrochemical Society, v. 156, no 2, p. D64-D69, 2009.

[51] Allanore, A; Lavelaine, H; Valentin, G; Biratand, J. P; Lapicque, F. Iron Metal Production by Bulk Electrolysis of Iron Ore Particles in Aqueous Media. Journal Of The Electrochemical Society, v. 155, №. 9, p. E125-E129, 2008.

[52] Haarberg, G. M; Kvalheim, E; Murakami, S. T; Pietrzyk, S; Wang, S. Electrodeposition of Iron from Molten Mixed Chloride/Fluoride Electrolytes. 210th ECS Meeting, v. 3, ed. 35, 29 Outubro - 3 novembro, Cancun, Mexico. 2006. 
[53] Zenkov, V. I., Pasichnyi, V. V. Reduction Kinetics of Iron Oxides Used For Hydrogen Production In Various Gas Media. Powder Metallurgy and Metal Ceramics, Vol. 49, 2010, Nos. 3-4.

[54] Kaushik, P; Fruehan, R.J. Behavior of Direct Reduced Iron and Hot Briquetted Iron in the Upper Blast Furnace Shaft: Part I. Fundamentals of Kinetics and Mechanism of Oxidation. Metallurgical And Materials Transactions B, v. 37B, p. 715-725, outubro 2006.

[55] Halder, S., Fruehan, R.J. Reduction of Iron-Oxide-Carbon Composites: Part I. Estimation of the Rate Constants. Metallurgical and Materials Transactions B. v. 39B, p. 784-795, dezembro 2008.

[56] Corbari, R; Fruehan, R.J. Reduction of Iron Oxide Fines to Wustite with $\mathrm{CO} / \mathrm{CO}_{2}$ Gas of Low Reducing Potential. Metallurgical and Materials Transactions B, v. 41B, p. 318-329, abril 2010.

[57] Turkdogan, E. T; Vinters, J. V. Gaseous Reduction of Iron Oxides.1. Reduction ofHematite in Hydrogen, Metallurgical Transactions, v. 11, no. 2, p. 3175-3188, 1971.

[58] Pescott, E. R. Kinetics of the Gaseous Direct Reduction of Iron Ores in Multi-Component Gas Mixtures, British Steel, 1976.

[59] Gaballah, I., Bert, P., Dufour, L. C., Gleitzer, C. Kinetics of The Reduction of Wustite by Hydrogen and Carbon Monoxide + Hydrogen Mixtures. Observation of trichites, Memoires Scientifiques de la Revue de Metallurgie, v. 69, p. 523-530, 1972.

[60] Turkdogan, E. T., Olsson, R. G., Vinters, J. V. Gaseous Reduction of Iron Oxides.2. Pore Characteristics of Iron Reduced from Hematite in Hydrogen, Metallurgical Transactions, v. 11, №. 11, p. 3189-3196, 1971. 
[61] Hayes, P. The Effect of Adsorbed Oxygen on The Kinetics of Chemical Reactions on Metal Surfaces, Metallurgical Transactions B: Process Metallurgy, v. 10B, no. 4, p. 489-496,1979.

[62] El-Geassy, A. A; Rajakumar, V. Influence of Particle Size on the Gaseous Reduction of Wustite at 900.Apprx.1100 ${ }^{\circ} \mathrm{C}$, Transactions of the Iron and Steel Institute of Japan, v. 25, ํo. 12, p. 1202-1211,1985.

[63] Devisme, O. Contribution À L'étude De La Réduction Des Oxydes De Fer Par L'hydrogène: Mécanisme Et Cinétique De La Réaction, Mémoire présenté en vue d'obtenir le diplôme d'ingénieur du Conservatoire National des Arts et Métiers, 2005.

[64] Hayashi, S., Iguchi, Y.. Factors Affecting the Sticking of Fine Iron Ores during Fluidized Bed Reduction, ISIJ International, v. 32, pág. 962-971, 1992.

[65] Komatina, M., Heinrich, W., The Sticking Problem During Direct Reduction, Metalurgija, p. 309-328, 2004.

[66] Zhang, B; Wang, Z; Gong, X; Guo, Z. A comparative study of influence of fluidized conditions on sticking time during reduction of $\mathrm{Fe} 2 \mathrm{O} 3$ particles with CO, Powder Technology, v. 225, p. 1-6, 2012.

[67] Hayashl, S; Sawal, S;. Iguch, Y. Influence of Coating Oxide and Sulfur Pressure on Sticking during Fluidized Bed Reduction of Iron Ores, ISIJ International, v. 33, p. 1078-1087, 1993.

[68] Bartels, M. WL; Nijenhuis, J; Kapteijn, F; Ruud V. O. J. Aglomeration in fluidized beds at high temperatures: Mechanisms, detection and prevention, Progress in Energy and Combustion Science, v. 34, p. 633-666, 2008.

[69] Higgins, D.R; Gray, N.B; Davidson, M.R. Simulating particle agglomeration in the flash smelting reaction shaft, Minerals Engineering, v. 22, p. 1251-1265, 2009. 
[70] Gransden, J.F; Sheasby, J.S. The sticking of iron ore during reduction by hydrogen in a fluidized bed, Canadian Metallurgical Quarterly, v. 13, p. 649657, 1974.

[71] Hayashl, S; Sayama, S; Iguch, Y. Relation between Sulfur Pressure and Sticking of Fine Iron Ores in Fluidized Bed Reduction, ISIJ International, v. 30, p. 722-730, 1990.

[72] Zhang, B; Gong, X; Wang, Z; Guo, Z; Relation between Sticking and Metallic Iron Precipitation on the Surface of $\mathrm{Fe}_{2} \mathrm{O}_{3}$ Particles Reduced by $\mathrm{CO}$ in the Fluidized Bed, ISIJ International, v. 51, p. 1403-1409, 2011.

[73] Zhong, Y. W; Wang, Z; Gong, X. Z; Guo, Z. C. Sticking behavior caused by sintering in gas fluidisation reduction of haematite, Ironmaking \& Steelmaking, v. 39, p. 38-44, 2012.

[74] Zhang, B; Wang, Z; Gong, X; Guo, Z. A comparative study of influence of fluidized conditions on sticking time during reduction of $\mathrm{Fe}_{2} \mathrm{O}_{3}$ particles with $\mathrm{CO}$, Powder Technology, v. 225, p. 1-6, 2012.

[75] Zhong, Y. W; Wang, Z; Gong, X. Z; Guo, Z. C. Sticking behavior caused by sintering in gas fluidisation reduction of haematite, Ironmaking \& Steelmaking, v. 39, p. 38-44, 2012.

[76] Meyers, M. A.; Tantevee, T. Stresses Induced in Iron-Ore Pellets by hydrogen Reduction. Metallurgical Transactions B, V. 17B, p. 217-227. 1986.

[77] Fruehan, R. J; Li, Y; Brabie, L; Kim, E-J. Final Stage of Reduction of Iron Ores by Hydrogen. Scandinavian Journal of Metallurgy, v. 34, p. 205-212, 2005.

[78] Wagner, C. Mechanism of The Reduction of Oxides and Sulfides to Metals, Journal of Metals, v. 4, p. 214-16, 1952. 
[79] St John, D. H; Hayes, P. C. Microstructural Features Produced by the Reduction of Wustite in Hydrogen/Water Gas Mixtures, Metallurgical Transactions B: Process Metallurgy, v. 13B, p. 117-124, 1982.

[80] St. John, D. H; Matthew, S. P; Hayes, P. C. Establishment of Product Morphology During the Initial Stages of Wustite Reduction, Metallurgical Transactions B: Process Metallurgy, v. 15, №. 4, p. 709-717, 1984.

[81] Turkdogan, E. T; Vinters, J. V. Gaseous Reduction of Iron Oxides.3. Reduction-

Oxidation of Porous and Dense Iron Oxides and Iron, Metallurgical Transactions, v. 3, ํo.6, p. 1561-1570, 1972.

[82] Gransden, J. F., Sheasby, J. S. Sticking of Iron-Ore During Reduction by Hydrogen in a Fluidized-Bed, Canadian Metallurgical Quarterly, v. 13, no. 4, p. $649-657,1974$,

[83] Nicolle, R., Rist, A. The Mechanism of Whisker Growth In the Reduction of Wustite,Metallurgical Transactions B: Process Metallurgy, v. 10B, №. 3, p. 429-438, 1979.

[84] El Moujahid, S; Rist, A. The Nucleation of Iron on Dense Wustite: A Morphological Study, Metallurgical Transactions B: Process Metallurgy, v. 19B, no. 5, p. 787-802, 1988.

[85] St John, D. H; Matthew, S. P; Hayes, P. C. The Breakdown of Dense Iron Layers on Wustite in $\mathrm{CO} / \mathrm{CO}_{2}$ and $\mathrm{H}_{2} / \mathrm{H}_{2} \mathrm{O}$ Systems, Metallurgical Transactions B-ProcessMetallurgy, v. 15, №. 4, p. 701-708, 1984.

[86] Buchsbaum, C; Schmidt, M. U. Rietveld Refinement of a Wrong Crystal Structure. Acta Crystallographica Seção B, p. 926-932, 2007. 
[87] Toby, B. H., $R$ factors in Rietveld analysis: How good is good enough? Powder Diffraction, v. 21, №. 1, p. 67-70, março 2006.

[88] Santos, C. de O. P. Aplicações do Método de Rietveld. Apostila do curso sobre o Método Rietveld. Instituto de Química. UNESP maio de 2009.

[89] Peterson, V. K. Lattice parameter measurement using Le Bail versus structural .Rietveld. refinement: A caution for complex, low symmetry systems. Powder Diffraction, v. 20, №. 1, março 2005.

[90] Sterrett, F.S.K.; Kennedy, S.E.; Sparberg, E.B., "A Laboratory Investigation of Concepts in Chemistry", Harper \& Row Publishers, New York, p. 30-32 1968.

[91] Henriksson, U; Eriksson, J.C., "Thermodynamics of capillary rise: Why is the meniscus curved?", Journal Chemical Education, v. 81, p. 150-154, 2004.

[92] Norma ASTM B214-46T Standart Analysis of Granular Metal Powders.

[93] Costa, R. V. P. da. Otimização da Resistência à Compressão de Pelotas de Minério de Ferro para Redução Direta pela Aplicação de Projeto Robusto. Dissertação de Mestrado. REDEMAT - UFOP-CETECUEMG, Ouro Preto - MG Brasil, p. 4-7, abril 2008.

[94] Restivo, T. A. G. Redução Carbotérmica de Óxidos de Urânio Assistida Por Banho Solvente. Tese de Doutorado. Escola Politécnica da Universidade de São Paulo. 2003. pág. 22-27.

[95] Husum, P. L.; Sorensen, O. T. Computer Controlled Forced Stepwise Isothermal Analysis. Thermochimica Acta, v. 114, p. 131-138, 1987.

[96] Paulik, F; Paulik, J. Kinetic Studies of Thermal Decomposition Reactions Under Quasi-isothermal and Quasi-isobaric Conditions by Means of the Derivatograph. 
[97] Sorensen, 0. T. Quasi-isothermal Methods in Thermal Analysis. Thermochimica Acta, v. 50, p. 163-175, 1981.

[98] Nigel J. C; Andrew K. G. Decomposition Reactions of Solids (An Experiment In Reviewing). Thermochimica Acta, v. 79, p. 323-370, 1984.

[99] Brown, M.E; Maciejewski, M; Vyazovkin, S; Nomen, R; Sempere, J. Burnham, A; Opfermann, J; Strey, R; Anderson, H.L; Kemmler, A; Keuleers, R; Janssens, J; Desseyn, H.O; Li, C; Tang, T. B; Roduit, B., Malek, J; Mitsuhashi, T. Computational aspects of kinetic analysis Part A: The ICTAC kinetics projectdata, methods and results. Thermochimica Acta, v. 355, p. 125-143, 2000.

[100] Dollimore, D. The application of thermal analysis in studying the thermal decomposition of solids. Therrnochimica Acta, v. 203, p. 7-23, 1992.

[101] Vyazovkin, S.V; Lesnikovich, A.I. Estimation of the Pre-Exponential Factor in the Isoconversional Calculation of Effective Kinetic Parameters. Thermochimica Acta, v. 128, p. 297-300, 1988.

[102] Vyazovkin, S.V; Goryachko, V.I; Lesnikovich, A.I. An approach to the solution of the inverse kinetic problem in the case of complex processes. Part III. Parallel independent reactions. Thermochimica Acta, v. 197, p. 41-51, 1992.

[103] Vyazovkin, S. Alternative Description of Process Kinetics. Thermochimica Acta, v. 211, p. 181-187, 1992.

[104] Vyazovkin, S. An Approach to the Solution of the Inverse Kinetic Problem in The Case of Complex Processes. Part 4. Chemical Reaction Complicated by Diffusion. Thermochimica Acta, v. 223, p. 201-206, 1993. 
[105] Vyazovkin, S., Linert, W. False Isokinetic Relationships Found in The Nonisothermal Decomposition of Solids. Chemical Physics, v. 193, p. 109-118, 1995.

[106] Vyazovkin, S., Wight, C. A. Model-Free and Model-Fitting Approaches to Kinetic Analysis of Isothermal and Nonisothermal Data. Thermochimica Acta, v. 340-341, p. 53-68, 1999.

[107] Sorensen, O. T. Thermogravimetric and Dilatometric Studies Using Stepwise Isothermal Analysis and Related Techniques. J. Thermal Analysis, v. 38, p. 213-228, 1992.

[108] Husum, P. L.; Sorensen, O. T. Computer Controlled Forced Stepwise Isothermal Analysis. Thermochimica Acta, v.114, p. 131-138, 1987.

[109] Chen, F; Sorensen, O. T; Meng, G; Peng, D. Thermal Decomposition of $\mathrm{BaC}_{2} \mathrm{O}_{4} \cdot 0.5 \mathrm{H}_{2} \mathrm{O}$ Studied by Stepwise Isothremal Analysis and Nonisothermal Thermogravimetry. Journal of Thermal Analysis, v. 53, p. 397- 410, 1998.

[110] Levenspiel, O. Engenharia das Reações Químicas, Vol-2. Cálculo de Reatores. John Wiley and Sons, EUA, p. 22-45, 1972.

[111] Brown, M.E; Maciejewski, S; Vyazovkin, S; Nomen, R; Sempere, J; Burnham, A; Opfermann, J; Strey, R; Anderson, H.L; Kemmler, A; Keuleers, R.; Janssens, J; Desseyn, H.O; Chao-Rui, L; Tang, T.B; Roduit, B; Malek, J; Mitsuhashi, T. Computational Aspects of Kinetic Analysis. Part A: The ICTAC Kinetics Project - Data, Methods and Results. Thermochimica Acta, v. 355, p. 125-143, 2000.

[112] Meyers, M. A.; Tantevee, T. Stresses Induced in Iron-Ore Pellets by hydrogen Reduction. Metallurgical Transactions B, V. 17B, p. 217-227. 1986.

[113] Frick, M. A. D. Caracterização de Minério de Ferro Por Visão Computacional. Dissertação (Mestrado). Programa de Pós-Graduação em 
Engenharia de Produção, Área de Concentração e. Tecnologia da Informação, da Universidade Federal de Santa Maria. Santa Maria, RS, Brasil, p. 19, 2008.

[114] Carioca A. C. Caracterização de Minério de Ferro por Espectroscopia de Reflectancia Difusa. Dissertação de Mestrado. Escola de Minas da Universidade Federal de Ouro Preto, Ouro Preto - MG Brasil, p. 13-15, março 2010.

[115] K. Ishii, K; Akiyama, T; Kashiwaya, Y; Kondo, S; The Rates of Reduction of Iron Ore and Water-Gas Shift Reaction. p. 1-13. 1986. Disponível em http://hdl.handle.net/2115/38021.

[116]. Nurni, V. N; Ballal, B. N. Model for Reduction of Iron Oxide Pellet with a C-O-H-N Gas Mixture Considering Water Gas Shift Equilibrium in the Gas While It Diffuses through the Product Layer. J Chem. Chem. Eng. V. 7, p. 666-670. 2013.

[117] Pineau, A; Kanari, N.; Gaballah, I. Kinetcs of reduction of iron oxides by H2 Part I: Low temperature reduction of hematite. Thermochimica Acta, V. 447, p. 89-100. 2006.

[118] Pineau, A; Kanari, N.; Gaballah, I. Kinetcs of reduction of iron oxides by H2 Part II: Low temperature reduction of magnetite. Thermochimica Acta, V. 456, p. 75-88. 2006.

[119] Turkdogn, E. T.; Vinters, J. V. Gaseous reduction of Iron Oxides: Part I. Reduction of Hematite in Hydrogen. Metallurgical Transactions. V. 2, p. 3175-3188, 1971.

[120] Vyazovkin, S.; Isoconversional Kinetics. Handbook of Thermal Analysis and Calorimetry: Recent Advances, Techniques and Applications M.E. Brown and P.K. Gallagher, editors Elsevier B.V., v. 5, Cap. 13, p. 503-538, 2008.

[121] Piotrowski, K; Mondal, K; Lorethova, H.; Sonawski, L.; Szymanski, T.; Wiltowski, T. Effec of gas composition on the kinectics of iron oxide reduction in 
a hydrogen production process. International Journal of Hydrogen Energy, v. 30, p. 1543-1554, 2005.

[122] Shimokawabe, M; Furuichi, R.; Ishii, T.; Thermochim Acta, v. 28; p. 951. 1979 .

[123] Sastri MVC, Viswanath B.; Int J Hydrogen Energy, v. 7; p. 287, 1982.

[124] Tienam M. J; Barnes, P. A; Parkes, G. M. B. Reduction of iron oxide catalysts: the inverstigation of kinetic parameters using rate perturbation and linear heating thermoanalytical techniques. Journal Physical Chemistry B, v. 105; p. 220-228, 2001.

[125] Wong P. L. M., Kim M. J., Kim H. S., and C. H. Choi Sticking behaviour in direct reduction of iron ore Ironmaking and Steelmaking, v. 26, №. 1, p. 53, 1999.

126 Komatina, M., Gudenau, H. - W. The sticking problem during direct reduction of fine iron ore in the fluidized bed. Metalurgija - Journal of Metallurgy, p. 309-328, 2004.

[127] Yi, L. Huang, Z. Jiang, T. Sticking of iron ore pellets during reduction with hydrogen and carbon monoxide mixtures:Behavior and mechanism. Powder Technology doi: 10.1016/j.powtec.2012.11.043, 2012.

[128] Wang, H; Sohn, H. Y. Effects of Reducing Gas on Swelling and Iron Whisker Formation during the Reduction of Iron Oxide Compact. Steel Research International, v. 83, no. 9, p. 903-907, 2012.

[129] Basdag, A. Arol, A. I. Coating of iron oxide pellets for direct reduction. Scandinavian Journal of Metallurgy, v. 31, p. 229-233, 2002.

[130] Sohn, I. Fruehan, R. J. The reduction of Iron oxides by volatiles in a rotary hearth furnace process: Part I. The role and kinetics of volatile reduction. 
Metallurgical and Materials transactions B, v. 36B, p. 605-612, outubro 2005. 